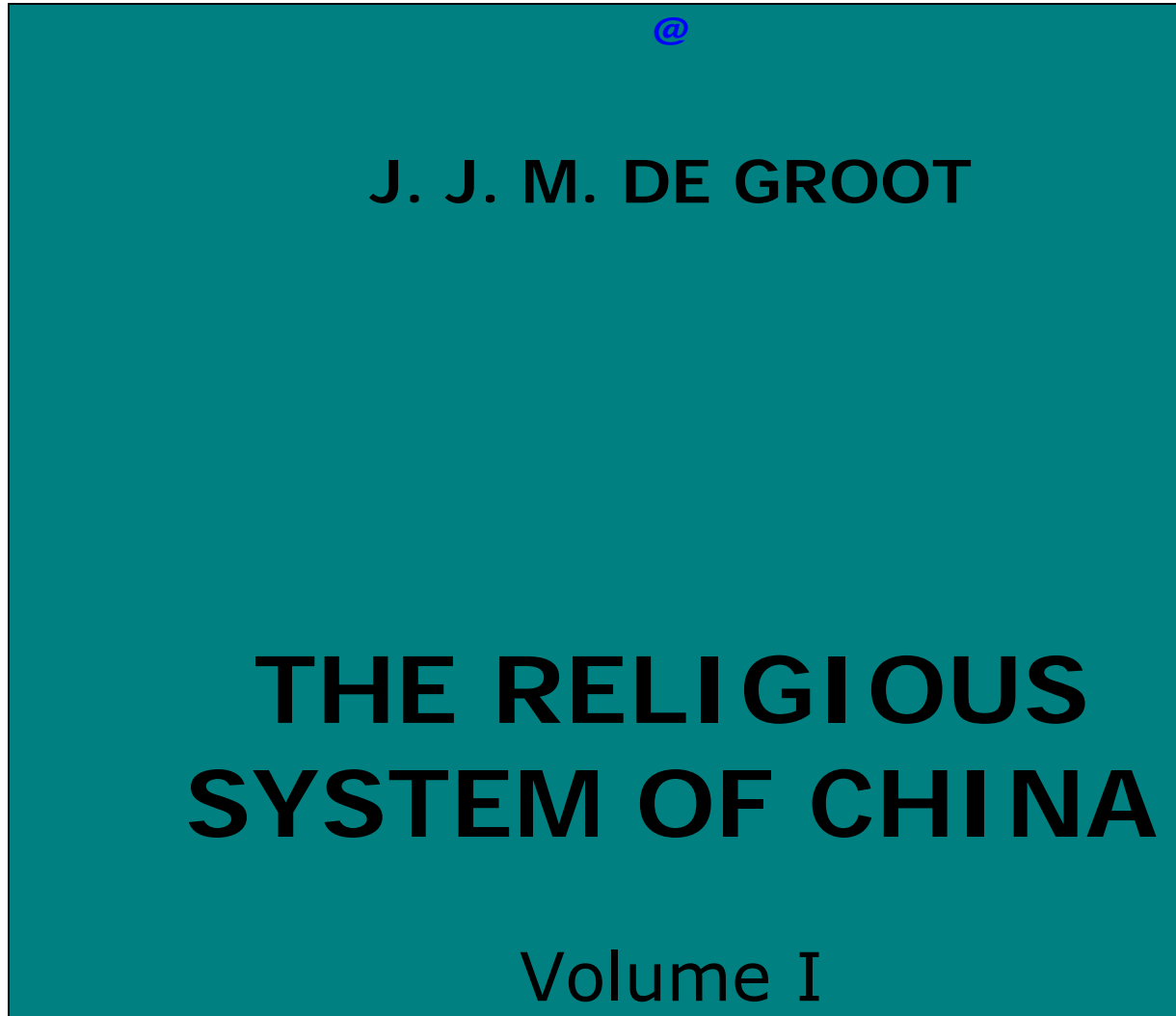

Dans le cadre de la collection : "Les classiques des sciences sociales" fondée et dirigée par Jean-Marie Tremblay, http://classiques.uqac.ca

Une collection développée en collaboration avec la Bibliothèque Paul-Émile Boulet de I'Université du Québec à Chicoutimi. http://bibliotheque.uqac.ca 


\section{Politique d'utilisation de la bibliothèque des Classiques}

Toute reproduction et rediffusion de nos fichiers est interdite, même avec la mention de leur provenance, sans l'autorisation formelle, écrite, du fondateur des Classiques des sciences sociales, Jean-Marie Tremblay, sociologue.

Les fichier des Classiques des sciences sociales ne peuvent sans autorisation formelle:

- être hébergé (en fichier ou page web, en totalité ou en partie) sur un serveur autre que celui des Classiques.

- servir de base de travail à un autre fichier modifié ensuite par tout autre moyen (couleur, police, mise en page, extraits, support, etc...),

Les fichiers (.html, .doc, .pdf., .rtf, .jpg, .gif) disponibles sur le site Les Classiques des sciences sociales sont la propriété des Classiques des sciences sociales, un organisme à but non lucratif composé exclusivement de bénévoles.

Ils sont disponibles pour une utilisation intellectuelle et personnelle et, en aucun cas, commerciale. Toute utilisation à des fins commerciales des fichiers sur ce site est strictement interdite et toute rediffusion est également strictement interdite.

L'accès à notre travail est libre et gratuit à tous les utilisateurs. C'est notre mission.

Jean-Marie Tremblay, sociologue

Fondateur et Président-directeur général, LES CLASSIQUES DES SCIENCES SOCIALES. 


\section{The religious system of China}

vol. I

Un document produit en version numérique par Pierre Palpant, collaborateur bénévole,

Courriel : ppalpant@uqac.ca

à partir de :

The Religious System of China, its ancient forms, evolution, history and present aspect. Manners, customs and social institutions connected therewith.

par J. J. M. de GROOT (1854-1921), Ph. D.

E. J. Brill, éditeur, Leiden, Volume I, 1892, XXIV+360 pages. Réimpression par Literature House, Ltd, Taipei, 1964.

Police de caractères utilisée : Verdana, 10 et 9 points.

Mise en page sur papier format Lettre (US letter), 8.5"x11".

Édition complétée le 20 octobre 2007 à Chicoutimi, Québec.

Ouvrage numérisé grâce à l'obligeance des Archives et de la Bibliothèque asiatique des

Missions Étrangères de Paris

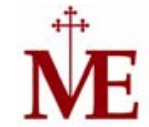

http://www.mepasie.org 
The religious system of China

vol. I

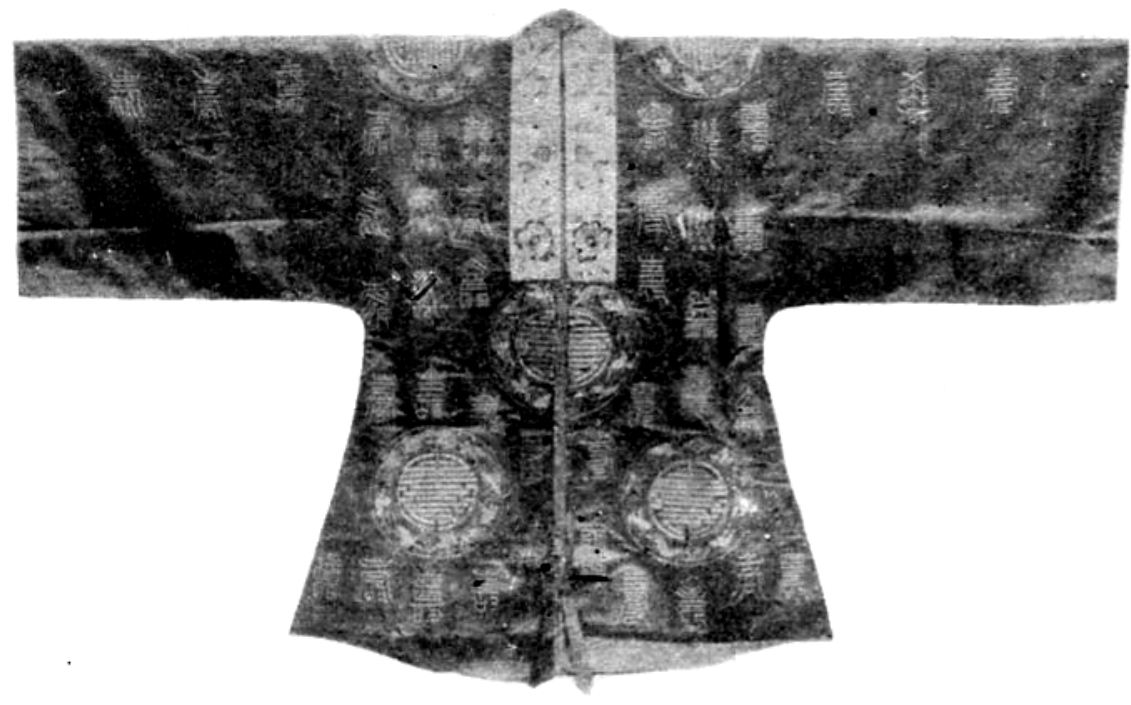

The front

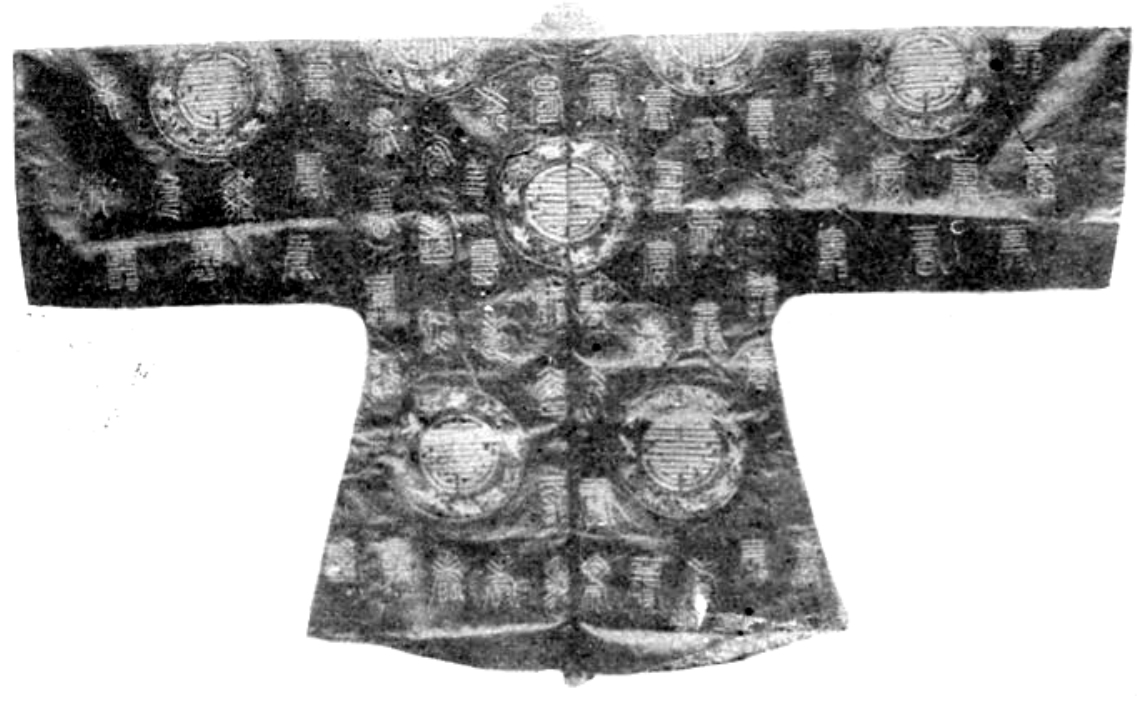

The Back

Frontispiece. Longevity Garment. 
The religious system of China

vol. I

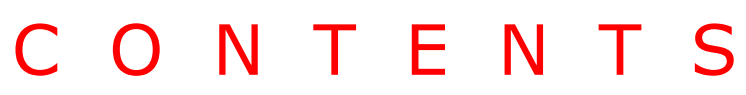

General preface

Remarks

\section{BOOK I. DI SPOSAL OF THE DEAD.}

INTRODUCTION

\section{PART I . FUNERAL RI TES.}

Chapter

I. The Decease.

II. The Interval between Death and the Dressing of the Corpse.

III. Dressing the Corpse : 1 . The Grave Clothes -2 . Dressing the Dead.

IV. Sacrifices and Rites between the Dressing and the Coffining.

V. The Coffining.

VI. The Interval between Coffining and Burial.

VII. The Burial.

VIII. Usages after the Removal of the Coffin and after the Burial.

IX. The Relationship between the ancient and modern Funeral Rites. Final Remarks.

PART II. THE I DEAS OF RESURRECTION.

Chapter

I. Calling back the Soul. The Death-howl.

II. On postponing the Dressing of be Dead, Coffining and Burial.

III. On placing Precious Objects in the Mouth of the Dead.

IV. On Coffins and Grave Vaults.

V. On some other Usages prompted by the Belief in a Resurrection : 1. Washing and Dressing the Dead. - 2. Keeping the Dead unmutilated.

VI. On the Cohabitation of the Soul and the Body after Death.

VII. Placing Food in the Mouth and by the Side of the Deceased.

$\underline{\text { Notes }}$ 


\section{The religious system of China}

vol. I

\section{P L A T E S}

Frontispiece. Longevity Garment.

I. Plan of an official mansion during the Cheu dynasty.

II. Sacrificial Attire for Family Chiefs.

III. Petticoat of a Bride.

IV. Mantle of a Bride, with Hair-pin, Boot, Hood and Girdle.

V. Mantilla of a Bride.

VI. Longevity Garment.

VII. Card with the news of death.

VIII. Portraits of a deceased Lady and Gentleman.

IX. The Spirit that clears the way.

X. Portable Pavilion.

XI. Catafalque without/with the drapery.

\section{F I G U R E S}

1. 'Deep Garment' of Antiquity.

2. Cowl called Hok kun.

3. Hair-pin resembling a Crosier.

4. Boy's Tunic of Antiquity.

5. Youth's Hat.

6. Roof-hat.

7. Temporary Soul Tablet.

8. Sheet of Treasury money.

9. Amulet for Purification.

10. Buddha Banner.

11. Streamer harbouring the Soul.

12. Candle Sticks with Incense Burner.

13. Sacrificial Goblets with Heron Jug and Wine Tankard.

14. Paper-Scatterer, Trumpeters, Flag and Lantern Bearers in a Funeral Procession.

15. Band of Musicians in a Funeral Procession.

16. Escort of official Attendants and Lictors in a Funeral Procession. 


\section{The religious system of China}

vol. I

17. Soul Banner.

18. Banner of Mourning Linen.

19. Ancient Catafalque for the Ruler of a State.

20. Ancient Catafalque for an ordinary Officer.

21. Cart for conveying Offerings to the Tomb.

22. Closed coffin of superior quality.

23. Open coffin of inferior quality. 


\section{The religious system of China \\ vol. I}

\section{GENERAL PREFACE}

p.VII Many books, and many good books, have been written on China. Yet the state of our knowledge of the Chinese Religious System is not such as to exclude all further study in the wide field it embraces, or to render unnecessary a publication of the results of new researches made therein. Consequently no apology is needed for the appearance of this work.

From what has heretofore been written on the subject in Europe and America, it is tolerably manifest that Religion in China is but little more than a great art, or combination of arts, for promoting welfare in this present life and future salvation, by following certain lines of conduct and by propitiating or rendering harmless certain classes of invisible beings and agencies. This art is regulated by customs, rescripts, and partly also by written laws issued by the Imperial Government; it is controlled to a certain extent by philosophy, and to a much larger extent by precedents set by the ancestors of the people. Many of these precedents have been unearthed by Western scholars, who have dished them up according to their lights and drawn from them many interesting conclusions. Some philosophical treatises have been translated in their entirety. But the present Religious System of the nation such as it lies open to the world has never been made a subject of serious study, neither has a picture ever been drawn of the Rites, Ceremonies, Rules of conduct and Discipline which are virtually practised by the people, nor have the ideas and doctrines which enforce them ever been sketched on an elaborate scale. In other words, Sinologists have never taken any serious pains to penetrate into the intimate Religious Life of the nation. p.VIII Therefore it cannot be a matter of wonder that the scanty existing works which aspire at exhibiting the Religious System as a whole, are simply pictures patched together from insufficient material giving but a very poor likeness of the original, nay, sometimes even a caricature.

The present work is an attempt at depicting the Chinese Religion as it is really practised by the nation, and at sketching on a broad scale its influence on Domestic and Social Life. It is the fruit of an intimate contact with the 


\section{The religious system of China}

vol. I

Chinese race for several years. Since first setting foot on the wide field of Sinological studies, the author has adopted a course of systematically committing to paper whatever customs, usages and religious observances presented themselves to his view either in the Middle Kingdom or the transmarine Colonies where Chinese emigrants have settled ; no opportunity of acquiring an insight into the different phases of Social and Religious Life of the Chinese has been allowed to escape him. The liberality of the Government of the Dutch Indies placed him in a position to pursue for years this line of investigation on the Chinese soil, where he lived in close contact with the people, periodically joining their family circles and spending much time in their Convents and Temples. He had thus an opportunity of gathering a rich harvest of scientific material in an extensive field hitherto unexplored. Priests of every sect, exorcists, necromancers, men of letters, professors of geomancy, in short, whoever might be presumed to stand in any relation with religion, have been constantly consulted ; large numbers of books, tracts and manuscripts have been collected, copied and translated ; thus light has been steadily derived from the one side to elucidate the other, and vice-versa. If the results of these labours should prove to be of some little use to Science, the latter will be indebted in the first place to the assistance and protection afforded the author by the Government of the Dutch East Indian Colonies, at that time represented by Their Excellencies Dr. J. P. Sprenger Van Eyk as Minister for Colonial Affairs, and Mr. O. Van Rees as Governor-General. It is here the agreeable duty of the author to publicly express his gratitude to these Statesmen.

It is scarcely necessary to say that it is impossible for any man to extend his researches in the boundless field of Ethnography and Religion over the whole area of the Chinese Empire. He would naturally find himself confined to a small part of it. For such purpose the writer has selected the southeastern departments of Fuhkien province, and in particular the town and island of Amoy. However, whenever the subject demanded it, p.Ix his investigations have been pushed much farther. Thus lengthy references will be found in this work to matters personally inquired into in the provinces of Kwangtung and Kiangsi, in the cities of Nanking and Peking and their environs, and in many other parts of the realm ; the data on the monastic 


\section{The religious system of China}

vol. I

life of the Buddhist clergy have all been collected in the northern districts of Fuhkien, because in the south of this province large Convents are now-adays conspicuous by their absence. The exiguity of the field wherein the researches have been chiefly pursued, cannot be a drawback. Observations made in different parts of China having only proved that, throughout this empire, the Customs and Manners in the Social and Religious domains are remarkable for their great uniformity on the more important points, consequently any part of the nation may safely be taken as a type of the whole, and local deviations do not seriously diminish the value of a picture drawn from such a type. On the other hand, there certainly is a great advantage in limiting the field of one's researches within narrow confines. It allows of an opportunity to check the correctness of each observation over and over again by repeated observations, thus ensuring exactitude and affording a valuable safeguard against serious errors and misinterpretations. The method hitherto so generally pursued of wildly grasping about for facts in different sub-divisions of the empire and presenting a compendium thereof as a picture of the whole nation, has rendered no good service to Science. On the contrary, Science has been led astray by being thus entangled in a mass of confused information, much of which had to be cast aside as utterly unfit for use, no one knowing to what part of the country it referred. Suppose for a moment that Spanish, Swedish, Greek and British customs were grouped together without any reference to the particular country in which a peculiar custom prevails, and presented to the world as a sketch of European life in general, would not every European immediately condemn the work as a ridiculous caricature ? Yet, books on China are written in this way, and no single word of protest is heard ; they meet with the general approval of the world, run through several editions, and Science is thrown back upon them as authorities, nay, as standard works !

The plan of this work being essentially different from that hitherto followed by most writers on Chinese Religion and Ethnography, very little material collected by them can enter into its composition. In one respect this is very satisfactory to the author, as this will stamp the p.x present work as an entirely new production, drawn up independently of all previous writers. 


\section{The religious system of China}

vol. I

The question has long occupied the mind of the writer whether it would not be preferable to confine himself strictly to a description of the Religious System in its narrowest sense, and thus considerably reduce the bulk of the work. This idea, however, has had to give way to the consideration, that such would entail a renunciation of the chief article in his programme, which is to depict the influence of Religion upon Society in its several degrees. The reader will soon become aware that, as with semi-civilized peoples in general, so in China religious ideas and usages pervade social life to its inmost recesses, that these are, so to say, the backbone of the manners and customs, of the domestic and political institutions of the nation, and to a large extent of its legislation. Whoever is acquainted with its religion, knows the people. It may be asked whether it is not too venturesome to undertake a work embracing such an extensive field. The answer to this is that the author's store of materials will enable him to complete it, if life and health be granted him. And should the present writer not finish his task, others may thereby be encouraged to take it up and complete it.

All the Manners, Customs, Religious and Social institutions are founded upon the past and are the embodied ideas of earlier generations. So, rightly to understand them, a knowledge of Antiquity is necessary. For this reason, the Manners, Customs, Practices and Rites dealt with in this work are as far as possible traced back to their fountain head, such as they are described in the literary remains of Ancient and Mediæval China. Native books which throw light on the actual state of things, are also made to serve as safeguards against misstatements and as useful guides to prevent our swerving from the path of truth and rectitude.

This method has one great drawback. It swells considerably the bulk of the work and renders the contents less attractive to the general reader. But, considering that the high stand-point which modern Science has attained, implicitly demands light from every reliable source from whence light may be drawn, no other plan was open to the writer. Moreover, nobody will deny that, apart from the plain facts gleaned from actual life, nothing is at present so much needed with regard to China as the translation of the treasures buried in the native literature. Giving due weight to this point, the

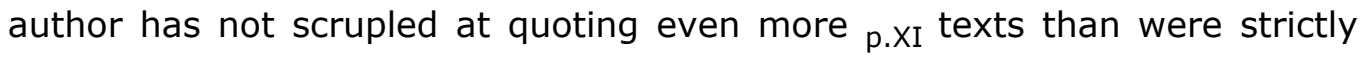




\section{The religious system of China}

vol. I

necessary for the elucidation of his subject. Nine at least out of every ten of these extracts it will be found have never been unearthed before. Where the length forms no impediment, the original Chinese texts are quoted at foot, that Sinologists may judge for themselves of the correctness of the English translation.

In thus describing the Religious and Social Institutions of China in both their ancient and modern form, the present work, when complete, will be found to present a picture of the growth of culture on yonder side of the globe. It will also be found to give a synopsis of the Philosophy of the empire, in so far as this has virtually struck root in the mind of the nation and operated upon its Religious and Social Life. It will review a great part of the domain of the Mythology of China; legends, popular tales and even childish superstitions will be reproduced in its pages in considerable numbers, as useful materials for attaining a knowledge of the conceptions and ideas of the people and of the true condition of their mental culture. By facts produced from both Chinese literature and actual life it will confirm as well as refute many conclusions arrived at by Western authors in the field of Ethnology, Sociology and the Science of Religion. China may, in fact, be considered a valuable touchstone for many of our theories in these branches of science, this being greatly due to its spirit of conservatism, now proverbial, which scarcely ever allows the nation to drop a custom bequeathed to it by former generations. Many rites and practices still flourish among the Chinese, which one would scarcely expect to find anywhere except amongst savages in a low stage of culture.

The task of comparing the Religious and Social customs of China with those prevailing elsewhere on the globe must, however, be left to others. For many years the author regularly noted down in his manuscript whatever parallels he came across in the course of his readings, but in the long run he had to discontinue this method, which proved too great a demand upon his time and encroached too much upon his studies of Chinese works. Moreover, if he had pursued such a course to the end, his manuscript would have swollen so enormously as to render its publication an impossibility. Therefore, in carrying this first volume through the press, all references to other tribes and nations, with the exception of a few brief notes, have been 


\section{The religious system of China}

vol. I

eliminated, and the same rule will be observed in all subsequent volumes. The reader will, however, soon become aware that those references have left a distinct p.XII mark upon this work, a mark chiefly manifested by the fact that the author has followed the beaten track of Science for the study of Religions and Sociology in general.

So far for the general scope of this work. A few words now remain to be said on its arrangement.

It will be subdivided in Books, each Book dealing with a separate part of the Religious System of China. Each succeeding Book will depend on the data supplied by the previous Books, so that the whole will form one catena, from which, however, any link may be detached and freely made use of separately. The two first parts of Book I are now before the reader and they may serve to convey a general idea of the method to be pursued to the end of the work.

The reason why the Usages connected with Deaths have been made the starting-point of this work, is set forth in a few introductory sentences on page 1 . The third part of Book I is now going through the press and will be soon be ready for publication in two volumes. It embraces the whole series of Customs, Practices and Institutions relative to the Tomb and the Body, after the latter has been placed therein. Besides suggesting a theory which may explain the origin of burying the dead, it deals with the ancient custom of depositing property, inclusive of wives and slaves, in the grave and depicts the profound influence this practice has exercised over society ever since, as also the customs which it has created in course of time, such as mourning, fasting, sacrificing the semblances of men, animals and things to the deceased, and the like. It contains elaborate descriptions of Tombs and Burial grounds of both ancient and modern times, and of the Imperial Mausolea of the late Ming dynasty, the oldest among the Chinese monuments of the kind which have escaped the ravages of time and the hand of man. It reviews the public and private protection which in China is awarded to the dead and their resting places, as also the legislation on this point. Many pages are devoted to the prevailing system of placing the 


\section{The religious system of China}

vol. I

graves under the beneficient influences of nature, in order that they may be rich sources of happiness to the survivors, a system which, while passing for the outcome of the profoundest wisdom and the most sublime science, has, under the name of Fung shui, ever exercised a most tyrannical sway over the mind of the nation. Besides numerous other subjects, the same volume elaborately treats of the p.XII exceptional methods of disposing of the dead, such as by cremation, water-burial, partial burial, and so forth.

The Second Book will deal more especially with the Soul. After reviewing the Chinese theories, ancient and modern, about the human duplicate, it will expatiate on Spirit-lore and Demonology, on the influence exercised everywhere by disembodied spirits upon the fate of man, on the numerous methods of rendering such influences harmless, methods which to a certain extent form the groundwork of Chinese medical science, if science it may be called. Much attention will be bestowed on the superstitions connected with names and the avoidance of the use thereof with a view to deceiving evil spirits, which practice has given rise to an elaborate system of conferring titles and honorary names on both the living and the dead. Some chapters will treat specially of benevolent spirits and the part they play in the Universe, showing the various methods, ancient and modern, of consulting these beings with a view to being guided by their revelations and so ensuring success to undertakings of any importance. Several chapters will be devoted to the systematic propitiation of the deceased ancestors by sacrifices and acts of worship both in the family circle on their graves and in temples dedicated to them, with which the soil of the empire is studded in incredible numbers.

Taoism was originally a compendium of customs and practices framed upon the prevailing ideas concerning the human soul. Adopting these as its own, it cast them into a system of Philosophy, Alchemy and Religion. This system is accordingly first dealt with after the Soul, in a separate Book. Under Taoist influence the primitive notions of a future existence developed into well defined doctrines about Paradises and Hells, which will consequently form one of the principal subjects of the Third Book. 


\section{The religious system of China}

vol. I

The Fourth Book will be devoted to the widest ramifications of the Religious System of China : the Worship and Propitiation of Human Souls beyond the circle of their own family or tribe, by the whole nation or a considerable part of it. Souls which are the objects of so much attention, whether they be identified with the powers of Nature and the constituent parts of Cosmos, or with animals, plants or lifeless objects, may be said to have been raised to the dignity of Gods and Goddesses, and indeed they have been generally so denominated by European authors ever since China was opened to them as a field of study. Important and comprehensive though this expansion of the Ancestral Worship be, p.XIV but very little attention has hitherto been paid to it by Sinology; scarcely any pains have as yet been taken to study the rites and ceremonies, by which the people uninterruptedly propitiate those divinities within their domestic circle and in the numberless temples sacred to their worship throughout the realm. The writer of this work has therefore been especially careful in collecting, during many years, whatever fell within the sphere of his personal observations on this point. Besides detailed accounts of the people's every day practices with regard to their Gods, the Fourth Book will contain descriptions of the Yearly Festivals instituted in their honour, of the Sacrifices, Masses, and Ceremonies to conjure epidemics, droughts and conflagrations. Much will be said about the Priests connected with this peculiar branch of the Religious System, as also about the Exorcists and Physicians who make it their vocation to be at times possessed of the gods and to act as the mouthpieces of their will. Large portions of the Book will consist of detailed monographies of all the principal Deities who actually perform a part in the field of Religious Life.

Buddhism, being an importation from a foreign country, must in turn be treated of next after the Religion of the native soil. While studying this Church in China, the writer followed the same plan which he had adopted with regard to the other branches of the Religious System, always directing his attention in the first place to the actual state of matters. He spent certain periods of time in the principal Convents of Fuhkien province, and long notes on the daily life and the religious performances of the Monks were committed to paper. The many unknown facts thus collected may 


\section{The religious system of China}

vol. I

probably be found useful to Science, information as to the actual monastic life both in China and other Buddhistic countries being, it is well-known, scanty in the extreme. Translations of the Laws of this Church, and of such of its Sacred Writings as really play a part within and without its pale, will also be inserted in the Fifth Book at considerable length, by far the greater part of such writings never having been rendered into any European tongue before. Much pains will be taken to define the place which the different branches, sects or schools of Buddhism occupy in China at the present day, as also to show the influence of this Church over the laity, an influence which is chiefly manifested by the creation of Vegetarian Sects with strongly pronounced eclectic tendencies, about which scarcely anything is as yet known, only hazy references based on mere hearsay evidence having got into print.

p.XV The Sixth Book will describe the State Religion, which is an official combination of such rites and ceremonies as are mentioned in the ancient Classics and consequently believed to have been practised by the first dynasties. It is quite an artificial religion standing apart from that professed by the bulk of the nation. Hence it is best to treat it last of all. The work will be completed with a history of the Taoist and the Buddhist Churches.

Each volume will be illustrated by zincographical figures and phototypical plates, all of which have been reproduced from photographs taken by the author himself in China, or from objects collected by him and now in the possession of several Museums, the greater part being at the Musée Guimet at Paris. The author much regrets that this comprehensive collection, made methodically so as to form one unbroken chain illustrating the most important pages of the religious life of China has had to be broken up into several parts, thus depriving it of much of its scientific value. And he deplores yet more that it has been lost for ever to his native country, in consequence of the behaviour of the Director of the National Ethnographical Museum at Leyden, for which institution he had destined it.

And now it only remains to request the reader's indulgence for the many defects in this work. No one can be more sensible of them than the writer 


\section{The religious system of China}

vol. I

himself. The book is intended less as a scientific production than as a storehouse of facts, carefully gleaned from actual life and expounded by data collected from the literary relics of bygone ages. Many of the explanations given of Practices, Rites and Customs may at first sight seem rash and venturesome. But let the reader in such cases suspend his judgment for a while, as these explanations will afterwards be found to be perfectly justified by facts adduced in other volumes. If notwithstanding all its imperfections this work should prove useful to Science as a leaf in the great book of human life, the author will feel himself amply rewarded for the hardships he endured on Chinese soil in collecting data during some of the best years of his life.

LEYDEN, February 1892. 


\section{REMARKS}

\section{on the orthography and pronunciation of chinese words occurring in this work}

p.XVI The vowels are pronounced as in German.

$\mathbf{a}$ is short when followed by $\mathbf{k}, \mathbf{p}, \mathbf{t}$ or $\mathbf{n g}$.

$\mathbf{i}$ and $\mathbf{o}$ are short when followed by $\mathbf{k}$ or $\mathbf{n g}$.

o has the round of aw in the English word straw.

$\mathbf{e}$ is pronounced as the first letter in the word ever.

The diphthong ai is pronounced like ie in lie, ao or au as ow in now. In the combinations ei, ia, io, iu, oa, oe, ui, each of the vowels must be distinctly heard, though without their sound being exaggerated ; in ia, io, iu and oa the last vowel is accented, and in ei, oe and ui the first. In oai, ai is accented.

A small $\mathbf{m}, \mathbf{n}$ or $\mathbf{n g}$ suspended at the end of a vowel indicates that the corresponding word in literary style actually ends in $\mathbf{m}, \mathbf{n}$ or $\mathbf{n g}$, but that in the spoken language of Amoy these letters are no longer pronounced and, instead thereof, the whole syllable has become nasal.

The consonants are pronounced as in English, but

$\mathbf{g}$ is always hard.

$\mathbf{h}$ is never silent, except at the end of a word, where it indicates that the vowel preceding it is short and abrupt. When it follows $\mathbf{k}, \mathbf{p}$ or $\mathbf{t}$, it always represents a distinct aspiration; hence, $\mathbf{p h}$ is never p.XVII pronounced as $\mathbf{f}$, nor th like the English th. In many cases, as after $\mathbf{c h}$ and ts, the aspiration is indicated by the sign ', suspended above the line.

$\mathbf{s}$ is always sharp.

ch is always pronouneed as in chance,

ng always as in song, 


\section{The religious system of China \\ vol. I}

oh as in shoe.

In order that the reader may immediately distinguish words in the Mandarin language from those in the spoken tongue of Amoy, the former, with the exception of proper names, are spaced $^{1}$, the latter italicized. An exception has been made for the titles of native works; these, though given according to the Mandarin pronunciation, are printed in italics.

In indicating the tones of the words derived from the colloquial language of Amoy, the same system has been followed as was adopted by Dr. Douglas in his Dictionary of that language. As this standard work must be on the shelves of every student and scholar who takes a real interest in the spoken tongues of China, it would here be superfluous to describe that system by repeating what the above mentioned author has already done so well in his Introduction.

${ }^{1}$ [css : le concept de mots étendus n'a pas été retenu dans la numérisation en fichier texte.] 


\section{REMARKS}

\section{on some of the chinese standard works, largely consulted in the preparation of this work}

p.XVIII The method followed in this work in dealing with the Religion, Manners, Customs and Institutions of the Chinese in their historical growth and development, has necessitated frequent reference to the principal historical works of the Empire. These works are the so-called Twenty-four Histories, collectively styled the Authentic Histories, each embracing the period of the reign of one or more dynasties. All the quotations made from these valuable documents are taken from an edition published in the fourth year of the Khienlung period (A. D. 1739) by Imperial command, which edition is undoubtedly the best now extant. Wherever this author could do so, he has traced back the information found in other books to these Standard Histories.

The following is a list of the Twenty-four Histories. After each is stated the period it embraces; thus the list will prove useful and convenient to the general reader, being a short dynastic and chronological table to which he can at any time refer while perusing this work.

1. Shi ki, Historical Records. Dating from Remote Antiquity to $122 \mathrm{~B}$. C. They embrace the dynasties of Hia (2205-1766 B. C.), of Shang or Yin (17661122 B. C.), of Cheu (1122-249 B. C.), p.XIX and that of Ts'in (249-206 B. C.) ; also a small part of that of Han.

2. Ts'ien Han shu, Books of the Early Han Dynasty. From 206 B. C.- 24. A. D.

3. Heu Han shu, Books of the Later Han Dynasty. A.D. 24-221.

4. San kwoh chi, Memoirs of the Three Kingdoms. A. D. 221-280. These comprise the histories of the three short dynasties Shuh, Wei and Wu, which bore sway at that time in different parts of the Empire.

5. Tsin shu, Books of the Tsin Dynasty. A. D. 265-420. 


\section{The religious system of China}

vol. I

6. Sung shu, Books of the Sung Dynasty. A. D. 420-479.

7. Nan Ts'i shu, Books of the Southern Ts'i Dynasty. A. D.479-502.

8. Liang shu, Books of the Liang Dynasty. A. D. 502-557.

9. Ch'en shu, Books of the Ch'en Dynasty. A. D. 557-589.

10. Wei shu, Books of the Wei Dynasty. A. D. 386-557.

11. Poh Ts'i shu, Books of the Northern Ts'i Dynasty. A. D. 550-577.

12. Cheu shu, Books of the Cheu Dynasty. A. D. 557-581.

13. Nan shi, History of the Southern part of the Realm. A. D. 420-589.

14. Poh shi, History of the Northern part of the Realm. A. D. 386-581.

15. Sui shu, Books of the Sui Dynasty. A. D. 581-618.

16. Kiu Thang shu, Old Books of the Thang Dynasty. A. D. 618-906.

17. Thang shu, (New) Books of the Thang Dynasty, embracing the same period.

18. Kiu wu tai shi, Old History of the Five Dynasties. A. D. 907-960. This is a history of five short dynasties, called Liang, Thang, Tsin, Han, and Cheu, which existed between the downfall of the Thang dynasty and the rise of the house of Sung.

19. Wu tai shi, (New) History of the Five Dynasties. A second historical work of the same period. p.xx

20. Sung shi, History of the Sung Dynasty. A. D. 960-1279.

21. Liao shi, History of the Liao Dynasty. A. D. 906-1168.

22. Kin shi, History of the Kin Dynasty. A. D. 1115-1234.

23. Yuen shi, History of the Yuen Dynasty. A. D. 1206-1368.

24. Ming shi, History of the Ming Dynasty. A. D. 1368-1644.

As standard authorities for the historical parts of this work we have also very frequently consulted the so-called Five Canons, , known respectively as :

1. Yih king, Canon of Metamorphoses.

2. Shu king, Canon of History.

3. Shi king, Canon of Odes.

4. Li ki, Treatises on Ceremonial Usages. 


\section{The religious system of China}

vol. I

5. Ch'un ts'iu, Annals, i. e. those of the state of Lu, where Confucius was born, and said to have been written by the sage himself.

Further we have largely made use of the Four Books, which are known as :

1. Lun yü, Discourses and Conversations.

2. Chung yung, Doctrine of the Mean.

3. Thai hioh, Grand Study.

4. Ming tsze, (Works of) Mencius.

The above nine works, which form important sources of our knowledge of China during pre-Christian times, are well known to Western science, having been translated into more than one European language. Numerous other native books have also been consulted in the preparation of the present work. A list of which will be given at the end of each Book.

The reader will observe that nearly all the quotations in this work are taken directly from Chinese literature. Cyclopædias, which abound in China, have only been made use ft exceptionally, when the author could not succeed in tracing any desired information to its fountain head, or could not obtain access thereto. This has been done to insure correctness, because Chinese encyclopædists are very inexact in quoting from other works, and consequently highly unreliable as authorities. One p.XXI striking exception to this rule there is, viz. the $K^{\prime}$ in ting ku kin thu shu tsih ch'ing, or Complete Collection of Illustrations and Literature, drawn up under Imperial Authority. This work, the largest ever compiled by the hand of man, was brought out under the Imperial auspices in 1725 ; it embraces nearly the whole native literature arranged under classified headings, each extract being retained in its original shape and unabbreviated. In composing the present work, the author has made great use of such trustworthy evidence. 
The religious system of China vol. I

\author{
$\mathrm{BOOK} \quad \mathrm{I}$ \\ D I S P O A L \\ OF \\ THE DEAD
}




\section{The religious system of China \\ vol. I}

\section{INTRODUCTION}

@

p.1 As in the case of many, if not of most barbarous and semi-civilized peoples, the human soul is in China the original form of all beings of a higher order. Its worship is therefore the basis of all religion in that country. As such, this worship begins already as soon as life is extinct, then manifesting itself chiefly in the treatment of the mortal coil, which survivors think continues to be inhabited by the soul and may perhaps return to life again. Therefore, in pursuing a systematical study of the religious system of the Chinese, it is quite natural to start from the manner in which they dispose of their dead. A rich store of information, highly valuable for the knowledge of the ideas really prevalent amongst the people regarding the condition of disembodied souls and the resurrection of the body, is in this way acquired. Besides, it affords data calculated to fully explain numerous important points and phenomena in such higher branches of the religious system as have either grown up from the worship of the dead, or, at any rate, developed themselves side by side with it, being incapable of withdrawing themselves from its mighty influence.

The customs described in this Book as observed by the Chinese of the present day are by no means conformed to by all classes of society. As has been remarked already by the ancient $L i k i$ (chapt. 4, leaf 40), « the rites and ceremonies do not go down to the common people » $(\underline{101})$, whose means are small and manners rude. p.2 As a basic for our descriptions we have selected the well-to-do classes and families of fashionable standing, amongst whom, in China, we chiefly moved, and these may be said best to maintain the whole system of the rites and ceremonies prescribed by the laws of custom. 


\section{P A R T I \\ FUNERAL RITES}

\section{CHAPTER I}

\section{The decease}

p.3 As in Western lands, so it is in Amoy a matter of great concern, a most sacred duty on the part of the nearest relations, to be present when a beloved and respected kinsman breathes his last. Wives, sons, daughters, grandchildren, brothers and sisters should not be absent at a death-bed. Neither are daughters-in-law allowed to stay away, as, in virtue of an established social law, any married woman has to behave in every respect towards her parents-in-law as if they were the very authors of her being.

In order to enable the relatives to be present in good time, they are, when the sick man is bad enough to cause the worst to be feared, as frequently as possible informed of his condition. Those who live far off do not even shun difficult journeys for the sake of exchanging a parting-word with the beloved senior and receiving his last instructions. It is, indeed, generally in presence of the whole of the nearest kindred that last dispositions are made, or, as Amoy people call it, "orders are given about the things to come", hoan-hù hō-sū ; - they may, of course, be taken down on paper as they come from the lips of the dying man, but written wills made beforehand while still hale and healthy are, in Fuhkien, quite exceptional. This is the reason why, if there is something to be bequeathed, the presence of interested parties as witnesses can not be dispensed with. 


\section{The religious system of China}

vol. I

A dying person is scarcely ever allowed to remain on his bed till he has expired. Even before matters take this fatal turn, he is transported to a couch of three boards supported by a couple of trestles or benches and covered with the same mat on which he was lying sick; sometimes, however, they give him a new one, if there is $p_{.4}$ one at hand. This peculiar death-bed goes by the name of tsúi-ts'ńg, 'water-bed', because the moribund is to be washed on it. In many cases, especially with the rich, it is screened from view by means of a white sheet hanging down from the ceiling at a distance of a few feet - obviously a very old custom, as in chapt. XI (leaf 17) of the $L i k i^{1}$ we read :

«Tseng-tszĕ (a disciple of Confucius) said : "Because the ornaments are not yet put on the corpse, they curtain off the main apartment of the house, and when the slighter dressing is over, they remove the curtain". Chung Liang-tszĕ said : "They curtain the main apartment off because husbands and wives are in confusion at that time, but after the slighter dressing they take the curtain away" (102).

As a rule, the water-bed is put up in the principal apartment, or the socalled thiang. Any one who has been in a Chinese p.5 dwelling is sure to

1 [][], or "Treatises on Ceremonial Usages". A famous Classic, compiled during the house of Han from ancient documents, a great part of which go back certainly as far as the Cheu dynasty. In Max Müller's series of Sacred Books of the East (vol. 27) Dr. Legge has given a translation of the whole work with an exposition of its origin and history, to which we refer the reader.

As that learned Sinologist justly remarks, more may be learned about the religion of the ancient Chinese from this Classic, than from all the others together (page 13). Consequently, in tracing the social and religious customs of the present day back to their most ancient forms, we shall have to make more frequent reference to it than to any other book. But nowhere shall we slavishly follow Dr. Legge's translations, admirable though they may be from a philological point of view. The reason is not that we object to the linguistic correctness of his renderings; but we have to take into account a commentary as valuable certainly as any paper one, viz. a body of customs and manners in as active force at the present day as in the very ages the Li-ki deals with. No doubt Dr. Legge himself would have modified his renderings on many points, had ha also had a living commentary like ours at his service.

All our quotations are taken directly from the great edition of the present dynasty, which bears the title [...], "Report on the rules laid down in the $L i-k i$, confirmed by imperial sanction". This was commanded in the $13^{\text {th }}$ year of the Khienlung period (1748) by an imperial rescript, and executed by a committee of 85 scholars and dignitaries, who, likewise in obedience to that rescript, also issued a new edition of the I li and the Cheu-li, two other great works of the Cheu dynasty which the reader will find mentioned respectively on p. 6 and p. 19. 


\section{The religious system of China \\ vol. I}

remember that central part of it, just behind the main entrance, sometimes separated from this by an inner court-yard. Guests are received and entertained here; moreover, it is a place for sacrificing to the tutelar divinities of the house and to the family manes, who, in the shape of images and vertical wooden tablets which we shall treat of more at length in our Second Book, occupy there an altar erected in the rear against the wall, just opposite the main door. Henceforth we shall call that apartment the hall. As it is a domestic temple in the true sense of the word, it bears a close resemblance to the atrium of the ancient Romans, which also contained the lararium or altar with the guardian-divinities of the home.

Before the dying man is removed to the hall, the said altar together with the objects of worship is taken to another apartment, it being considered inconsistent with the respect due to the sacred ones to allow them to have the shocking and unpleasant spectacle of death before their eyes. But if there is no room in the house spacious enough to contain the altar, it is simply covered over with a white sheet, white being the colour of mourning.

The water-bed is not invariably placed on the same spot in the hall. If the dying person is a senior of the family, that is to say a father or mother whose own parents have died before, or, in a family of orphans, an elder brother, unless the grandfather or grandmother is still living, it is put up on the place whence the altar has been removed, this being the chief spot, the place of honour in the house. The moribund is, in this case, placed on it with his head to the left, or, as the Chinese express it, to the east, the front of the hall being considered to face the South ${ }^{1}$. But a junior member, and a concubine, unless she has given birth to a son who is the pride of the family because he occupies an official position or has been promoted to a considerable rank, is, as a rule, laid out along one of the side-walls, or on the east or west, as Chinese say, where are the places and seats of second and third order. In such a case the feet must point to the door. And as for childless concubines, slaves, servants and the like, they are not allowed a place in the hall at all, but are simply laid down to die in some inferior apartment of the house.

\footnotetext{
${ }^{1}$ Anciently all buildings of importance faced the south in point of fact.
} 


\section{The religious system of China \\ vol. I}

The transportation of the moribund to the water-bed goes by p. the term $p o a^{n}-p h \underline{o}{ }^{1}$, 'to remove or transmit the bedding'. When it has been duly performed with the necessary care, his whole body is wiped clean with a towel and lukewarm water in which in some cases leaves of the banian or peach-tree have been decocted. This ablution is performed by the wife, or a daughter-in-law, and only in default of such next-of-kin by any one else. They also shave his head and face and change his clothes, that he may depart clean and in a neat attire from this world of cares : indeed, souls appear in the other world in the same state in which they leave this material one. Finally the body is covered with a sheet and allowed to remain where it is, to breathe its last quietly.

People in more favourable pecuniary circumstances generally have the shaving and cleansing of the head performed by a barber. This man is not paid the customary fee due from a healthy client, but charges much more, in proportion to the wealth of the family. It is a rule of etiquette to hand him the money wrapt up in a piece of red paper, red being in China the symbolic colour of good fortune which dispels all inauspicious influences resulting from the contact with death. If the family can afford the expense, the hair of a dying female, after having been carefully dressed by the other women, is adorned with natural and artificial flowers, gems, silver hair-pins, and the like.

If the dying man possesses grave-clothes made during his lifetime, it is usual for the family to arrange them now around him. They place the boots by his feet, the gowns and trousers by his side, and the hat behind his head, with the object of making the man in the last moments of his life rejoice at the prospect that he will be most fashionably attired in the regions beyond the grave. In return, the moribund, if he has not yet fainted away, will express his gratitude to the bystanders for their dutiful care in ensuring his future happiness.

Like many other customs now-a-days observed by the Chinese, that of removing a dying man from his sick-bed and changing his clothes can be 


\section{The religious system of China}

vol. I

traced to very ancient times. The $I$ li $^{1}$ has in chapt. 31 p.7 (leaf 1 seq.) the following passages, referring to the ages prior to the Han dynasty :

«An officer is placed in the principal back-chamber, and lies down there with his head towards the east, under the northern wall. If sick, he composes his mind, and those who attend on him all compose their minds too. Lutes and lyres are removed. When the illness is extreme, they sweep the premises both inside and out. They take the contaminated clothes off and put new ones on the sick man. Four attendants sit down to hold his limbs, and males and females change their dress. Some fine floss of cotton is put on the mouth and nostrils, to mark when the breath is gone. A man does not expire in the hands of women, nor a women in the hands of the men (103). They go and address prayers to the five objects of sacrifice, and at the demise the chief mourner cries, and the brothers wail. They then erect a bed with mats near the lattice-window. As for these sleeping mats, one of kienstraw is placed under, and one of fine bamboo above. They place on the bed a pillow for the head, and subsequently transfer the corpse to it.

Nowhere is it said that the patient was allowed to expire on a bed; so it would follow that, while still alive, he was merely laid down upon the floor. This is, indeed, admitted to be so by commentators, who base their opinion on this passage in ch. 57 of the Li ki (leaf 1 ):

«When the illness is extreme, he lies down with his head towards the east under the northern wall, having left his bedstead.

p.8 Although, in those times, people of distinction were not allowed to die on a bed, it was considered bad form to leave the body on the floor while

\footnotetext{
1 Or «Rites and Ceremonial Usages ». It is another grand collection of the same character as the $L i-K i$, but far superior to this classic in the methodical arrangement of its subjects. Its re-appearance in the beginning of the Han dynasty has also been discussed by Dr. Legge in the introduction to his translation of the $L i-k i$; hence we may remain silent about it. The $I$ li contains a detailed description of the funeral rites for officers and their parents, wives and eldest sons, extending over six chapters to which we shall have to refer very often in this Book. All our quotations are taken directly from the great imperial edition mentioned in the foot-note on page 4, and which bears the title [..], « Report on the rules laid down in the $I$ li, confirmed by imperial sanction ».
} 


\section{The religious system of China}

vol. I

preparing it for the coffin. Besides the above quotation from the $I / i$, it is proved by the following clause, taken from chapter 11 of the Li Ki (I. 22) :

«Pen, the superintendent of officers, said to Tszĕ-yiu (a disciple of Confucius): "I beg permission to dress the corpse on a couch", whereupon Tszĕ-yiu said: "I allow you to do so". Hien-tszĕ, on hearing this, said: "How arrogant is this senior, he privately allows people to do what is the proper rule" (104).

In the age of Confucius some classes, however, seem to have deemed it sufficient to ensure a happy and fashionable demise if the sleeping mat of the dying man was simply changed for a fresh one. Chapter 9 of the Li ki (I. 38) says :

« Tseng-tszĕ (a disciple of the sage) was lying in his chamber very ill. "Yuen, said he (to his son), get up and change my mat." But TsengYuen replied: "The illness of my master is extreme, therefore it may not be changed. If we are so happy as to see you survive until the morning, I will beg your leave to reverently change it." To which Tseng-tszĕ replied: "What do I ask of you, nothing but to die in the correct way" - whereat they took him up and changed the mat. When he was replaced upon the mat, he expired before he could compose himself (105).

The doctrine that a dying person must give up the ghost on a water-bed is, now-a-days, far from obtaining as a peremptory customary law. The 'removal of the bedding' before life is extinct, on the contrary, occurs only in case the dying man is so wasted by the infirmities of old age, or is in such a desperate condition by slow and continued illness as to make the family give up all hope of recovery. In any other case, nobody would suffer the dying man to be touched as long as there remained a single sign of life in him. Consequently, numbers of people are not p.9 washed and laid out until they have actually breathed their last, so that not so many have their end hastened by the process as one might at first surmise ${ }^{1}$.

\footnotetext{
1 Perhaps it is worth observing, that the custom of placing the corpse upon boards immediately after death, prevails also in some parts of Europe. « In Orkney, according
} 


\section{The religious system of China}

vol. I

Before leaving this subject of the water-bed, we must refer to a curious specimen of popular superstition connected with it. For some obscure reason, perhaps for no reason at all, it is, as we saw, made up of three boards. This is a sufficient ground for most natives of Amoy never to lie down or to sleep on a bed consisting of this number of boards : if they did so, they might meet with an untimely death, anyhow fall a victim to misfortune. For the same reason it would be excessively rude, even impudent, to offer a guest a couch or a bed made of three boards. Once, in 1877 , on one of our journeys through Fuhkien province, having put up for the night in a small boat because there were no better lodgings in the place, our servant, otherwise a very intelligent specimen of the 'boy' class, obstinately refused to sleep on the floor of the cabin, simply because he had noticed two parallel seams there; he took up his quarters for the night on the open poop, under a rough November sky. No doubt this superstitious fear must be classed with the objections which many of ourselves would certainly raise on being ordered to sleep in a case shaped exactly like a coffin.

Before passing on to the customs and ceremonies which play a part subsequent to death, we must note that, when the time of dissolution is evidently drawing near, the orthodox and notable among the citizens have their hall and premises swept and cleaned, with a view to the sympathizing friends and kinsmen, who are expected to come on the news of the death to offer condolences to the afflicted family. This is confessedly in harmony with both the I li and the Li Ki, that say, as we saw on page 7 : « When the illness is extreme, the premises are swept clean both inside and out ».

to Gough, funeral ceremonies are much the same as in Scotland, the corpse being laid out after being stretched on a board till it is coffined for burial. And Pennant records that, on the death of a Highlander, the corpse is stretched on a board and covered with a coarse linen wrapper ». (Brand, Observations on popular Antiquities, Customs at Deaths). 


\section{The religious system of China \\ vol. I}

\section{CHAPTER II}

\section{The interval between death and the dressing of the corpse}

The death howl.

p.10 Until the fatal moment of death, the relatives confine the expression of their sorrow to a good deal of suppressed sobbing and tears. But scarcely the last gasp over, they all break out into loud wailing and passionate lamentation. The voices of the women are loudest in this dismal concert ; kneeling down at the water-bed and holding a piece of white cloth to their eyes, they pour forth at times with great vehemence bitter cries and piteous wails of woe. It is a melancholy concert of death dirges, a catenation of complaints addressed to the dead, in accents of reproach for leaving them. A son, in a slow, doleful cadence, asks : Goá pē eh, lí tsài thang tsō lí khì, pàng goá $m$ tsiâng lâng, "My father, can you allow yourself to go and leave me behind not yet grown a man!" And a wife wailingly chants : Goá, ke-khaó eh, Ií tsài thang tsō lí khì, àm toē lâi hāi lí, "My husband, how can you allow yourself to go ! The dark regions will harm you", and so forth.

It appears that in ancient China the dead were bemoaned in much the same way. Besides the testimony of the $I$ li, as quoted on page 7 , we have in chapter 57 of the Li ki (I. 10 and 13):

«Immediately after the demise, the principal mourners cry, the brothers wail, and the women wail and stamp their feet... Whenever they wail beside the corpse in the back-chamber, the chief mourner, while wailing, holds up the shroud with both his hands (106).

The loud and clamorous bewailing of the dead is by no means p.11 the expression of a deep emotion of the soul, of bitter sorrow or painful grief. It is, on the contrary, mainly a ceremonial observance prescribed by customary law, part of the conceived duties of nearest relatives towards a departed one, in a word, a mere rite. The sole fact that both the $I$ li and the Li ki formally 


\section{The religious system of China}

vol. I

prescribe it, is sufficient to testify to the correctness of this view. No doubt we have here a relic of uncivilized ages, as savages are well known to be very clamorous in their grief. This matter will be made a subject of closer attention in the second part of this Book, chapt. I. We shall there demonstrate that, instead of an expression of feelings of woe and sorrow, the rite in question is intended as a regular attempt to induce the wandering soul to come back and revive the corpse ${ }^{1}$.

\section{Closing the eyes.}

In case the dead person does not close his eyes and mouth himself, this is taken as a sure evidence that his departed soul feels uneasy about some matter. His wife, son, or another near relative will then try to comfort him by declaring in a coaxing tone of voice that there is nothing to depress his mind, everybody being sure to take the greatest possible care of his body and grave, to faithfully execute his last dispositions, and to regularly sacrifice food and clothing to his soul for years and years to come. After this, they gently close his eyes and mouth, thus dealing with their beloved dead as we are accustomed to deal with ours 2 .

\footnotetext{
1 We note here, that the Chinese custom of addressing the dead in terms of reproach for having gone, is exactly paralleled amongst several uncivilized tribes, though in slightly varying forma. To confine ourselves to one authority. Spencer says :... « This introduces us to the widely prevalent practice of talking to the corpse : primarily with the view of inducing the wandering duplicate to return, but otherwise for purposes of propitiation. The Fijian thinks that calling sometimes brings back the other-self at death ; and we read that the Moondes, or Hos, even call back the spirit of a corpse that has been burnt. Cruikshank says that the Fantees addressed the corpse 'sometimes in accents of reproach for leasing them, at others beseeching his spirit to watch over and protect them from evil.' During their lamentations, the Caribs asked 'the deceased to declare the cause of his departure from the world'. In Loango, a dead man's relatives question him for two or three hours why he died; and on the Gold Coast, 'the dead person is himself interrogated' as to the cause of his death : a statement of Beecham confirmed by Winterbottom. » (The Principles of Sociology, Vol. I, ch. 12, § 83).

2 It is almost superfluous to mention the fact, that the practice of closing the eyes and lips of the dead has always prevailed very widely, if not universally, in our western world. According to Pliny, it obtained as a holy custom among the ancient Romans ; the eyes were opened again, however, on the funeral pile, because no man was allowed to receive the last look of a being and it would have been a crime to rob it from heaven (Historiae Naturalis, I. XI cap. 37, de natura pupillae). Valerius Maximus (I. II cap. 6) calls this supremum opprimendorum oculorum officium. With the ancient Greeks, the closing of the eyes was likewise a matter of high importance, as may be inferred from this wish of Penelope :
} 


\section{The religious system of China}

vol. I

p.12 We remember the following tale was circulating in Amoy in 1886. A notable citizen of that port, in dying, suddenly began to bleed at the nose. His son, a bad character who knew himself to be such, was so affrighted at the sight that he dropped on his knees, solemnly promising henceforth to behave better, whereupon the bleeding stopped immediately.

Opening the sky-light.

If the dead died in the flower of life or in full manhood, one of the first things for the family to do is to open one of the skylights, in order to allow the disastrous influences, which have caused the death and might attack others also, to escape from the house. But in the case of an elderly man or woman this wise precaution is as a rule dispensed with, such a death being attributed rather to the natural course of terrestrial matters than to abnormal influences operating in an unnatural way. Never, however, is this neglected when death has resulted from leprosy, for, owing to the loathsome character of this disease, the contagion emanating from such a corpse is dreaded far more than any other. Many Chinese hold that the window is simply unclosed for the convenience of the soul, which ought to be allowed to wander freely and out ${ }^{1}$.

Closing the shop.

Di, precor, hoc jubeant, ut, euntibus ordine fatis,

Ille meos oculos comprimat, ille tuos.

${ }^{1}$ If the Chinese are right in that suggestion, we may again connect a custom of theirs with analogous practices in other parts of the globe. « During the blessing or 'saining' of a corpse in Scotland, says Dennys (The Folk-lore of China, ch. II), all the windows of the house are opened so as to give the soul free egress. When a death takes place, in many parts of Europe, all the doors and windows should be unfastened, as it is thought that the first pains of purgatory are inflicted by the soul squeezing through the closed doors. We have something like this in Swift's Journey from this World to the Next, where the spirits, conversing on their way to the throne of Micros, relate to each other how they had to wait till an open door or window in the house in which the death had taken place enabled them to get free from it. There is a curious superstition in Devonshire that the departure of life is delayed where any lock is closed in the dwelling or any bolt shot. » Similar ideas prevail also in Celebes : amongst the Bugis and natives of Macassar, says Van Eck, when any one lies down in the agony of death, doors and windows are thrown open, and everything in the house that is locked and bolted is unfastened, all to facilitate the departure of the soul (Indische Gids, January 1882, page 71). 


\section{The religious system of China \\ vol. I}

Knowing that people generally dislike visiting places where they may come in contact with death or anything connected with it, p.13 any family of shopkeepers that has a death to bewail will, if the house is small, close the premises on the street-side by means of the wooden shutters which are used in ordinary times during the night to keep out thieves. In this way they silently intimate that the trade stands still for the time being. No such measures, however, are taken in many cases when the dwelling is large enough to allow business to go on quite separated from the funeral rites, a friend or distant relative being then, as a rule, charged with the management of the shop, whereas the nearest kindred have no time to look after it themselves until the coffining or the burial is over.

\section{Procuring sackcloth garments.}

Among the requirements of the funeral rites, clothes of brownish sackcloth of the coarsest description stand foremost. They are worn by the nearest relatives by way of deep mourning-dress whenever they have to go through a rite of importance connected with the disposal of the dead, sons and grandsons then unbraiding their cues, and laying aside the silken cords, which in ordinary times used to be twisted in them to make them longer. It is, indeed, requisite to have the hair hanging down upon the back disheveled and neglected when in deep mourning ; but the daughters, daughters-in-law and wife of the deceased need not unbraid their plaits. They only lay aside the ornamental pins, flowers and the like, not to use them again until the burial is over.

The said sackcloth garments, which will be described in full detail in the third part of this Book, ch. VI, are, in most cases, hired for money in a kind of establishments called kó-ch'e-tièm, lit. 'shops of drums and windinstruments', or hûn-tîng-tièm ${ }^{1}$, 'shops of soulpavilions', where everything required for the equipment of funeral trains and bridal processions may be procured for temporary use, inclusive of the music. Well-to-do people sometimes have the clothes made for themselves at home, which, owing to

\footnotetext{
1 The meaning of this name may be learned from chapter 7 , where those soulpavilions and their part in the funeral processions are described.
} 


\section{The religious system of China}

vol. I

the low quality of the p.14 material, requires but very little time and money ; but nobody ever keeps them in his house ready made, as they would exercise a deadly influence over the inmates, and very likely entail cases of untimely death.

Washing the dead.

Attired with that coarse apparel, all the sons and grandsons, even those who are scarcely able to walk, silently repair to some well in the vicinity, the eldest carrying a bucket in his hand. On their way they mournfully droop their heads, so that their eyes behold nothing but the pavement of the street. Arrived at the well, the eldest son throws in a few coppers as an offering to the water-ghost, who does not like to be deprived of a part of his property without being paid for it; then the son draws some water and takes the bucket home, all his brothers in the rear keeping up the same kind of lamentations and death dirges which the family chant and wail at the moment of the decease. As soon as the females, who have staid at home, become aware of their approach, they join in the melancholy concert. In many cases, the eldest of the water-fetchers may be seen going along the street supported by a friend, or, if he is a stout and heavy man, by two friends, one on either side, for a mourning son or grandson, who understands his duties well, ought to be, or at least appear to be so bowed down with grief and sorrow as to be unable to walk without assistance.

The ceremony described, which has for its object the procuring of water for washing the dead, is at Amoy called khit-tsúi, 'to beg for water'. If the family is of some standing, the 'water-beggars' are accompanied by a servant who carries the bucket and draws the water, it being incompatible with highlife to perform any coarse labour whatever. But, while the dipping of the bucket is done by the servant, the sons loosely grasp the end of the rope, to take at least the appearance of doing the work themselves. In default of sons and grandsons, the duty of fetching water devolves on the wife, the daughters-in-law, or the unmarried girls. And if the eldest male descendant is a baby, he is borne in sackcloth garments to the well in the arms of a fullgrown person who, having put the coppers in the hand of the little one, opens it, thus causing them to drop into the water. 


\section{The religious system of China}

vol. I

The office of washing the dead is, as a rule, performed by one p.15 of the female inmates of the house, or if there are none who dare do the work, by an elderly woman, whom experience has rendered familiar with matters of this kind. The corpse is not stripped for the washing, but the hand is passed under the garments, it being simply wiped clean with a wet towel. In very exceptional cases, e. $g$. when death has been caused by a loathsome or contagious disease, or if the deceased has become very unclean while dying, in short, whenever there is nobody in the family who dares do the washing, the intervention of hirelings is secured, who are accustomed to demand a comparatively high pay for the unpleasant job.

As no one cherishing any respect for the beloved dead can allow the substance which is generally excreted at death, to remain about the body, the custom of washing the dead undoubtedly prevails all the world over. And so, it can not be a matter of astonishment to find it obtaining also in other parts of the Chinese empire, far from the one we are more specially dealing with. In the ninth volume of the China Review (page 397) we read :

«Rites performed for the dead; [][](i. e. to buy water). When a mother or a father of a family dies, the son will take a basin and two cash and go to the water-side - in Hongkong a hydrant will do as well. The cash are thrown into the water, and some water is dipped up in the basin. This is taken back to the house and a mock-washing of the body is performed; not a drop of water is allowed to fall on the body or on its clothing, but the son stands near the body, and with a towel dipped in the water pretends to wash it.

Dr. Gray, China, ch. 72, writes :

«Should a person die unexpectedly, or before his relatives have had time to dress him in his best robes, the next-of-kin attires himself in sackcloth, and hastens to the nearest river or well to buy from the HoiLoong Wong or River Dragon King, water wherewith to wash the face and body of the deceased. Four cash, and in some instances a live fish as well, are cast into the stream by way of payment. The fish is supposed to inform the river-god that the water has been bought and paid for. The nearest of kin is accompanied to the well or river by 


\section{The religious system of China}

vol. I

several friends, two of whom support him, one on each side, for he is supposed to be bowed down with grief. The procession is headed by two or more minstrels, the discordant sounds of whose p.16 musical instruments cannot easily be forgotten by one who has once heard them.

The practice of buying water for washing the corpse is also mentioned by Williams, in his Middle Kingdom (ch. 18). It was observed at least seven centuries ago on the extreme south-western part of the Chinese coast, as is shown by the Ling-wai-tai-tah ${ }^{1}$, which has in its sixth chapter :

«When a native of Khin 2 has died, the filial sons forthwith unbraid their hair, put on a hat of bamboo, take a water-dipper, a jar and mock paper money, and repair to the water-side. Here they lament bitterly, cast the money (the paper money aforesaid ?) into the water, and, having dipped up water, return home to wash the corpse. They call this 'to buy water'. If they do not act in the way described, their neighbours and fellow villagers will look upon them as unfilial people. Now-a-days, the natives of Khin use water, purchased for money, for their meals and for the supply of their kitchen. They call it 'sold water', and it is reputed to avert fatal events.

Neither can we wonder at finding the custom, now under our notice, in ancient China. The $I$ li, describing the funeral rites of ordinary officers, their parents, wife and eldest son, has :

«The overseers of the waste and cultivated grounds dig a pit between the steps ${ }^{3}$, a little towards the west-side, and contrive a furnace

1[][][][] , « Answers relative to matters beyond the Mountain-ranges ». It is a remarkable little work by Cheu Khü-fei, an official of the twelfth century, full of interesting notes on the geography and ethnography of the southern provinces of the empire and foreign Asiatic countries, extending even to the far west of China, and to Sumatra and Java.

2 The extreme western coast district of the present Kwangtung province.

3 Any building of importance was, in ancient times, erected on a square terrace having two flights of steps in front. As the front faced the south, the steps were on the east and the west.

In order to assist the reader in better understanding many an extract from the ancient books inserted in this work, we give a rough plan of an official dwelling during the Cheu dynasty, compiled from illustrations in the Khienlung edition of the $I$ li, which were drawn from information contained in the old works. 


\section{The religious system of China}

vol. I

under the western wall (of the court-yard) with its frontside facing the east. Water-basins, washing tubs, a p.17 water-dipper, a vase without

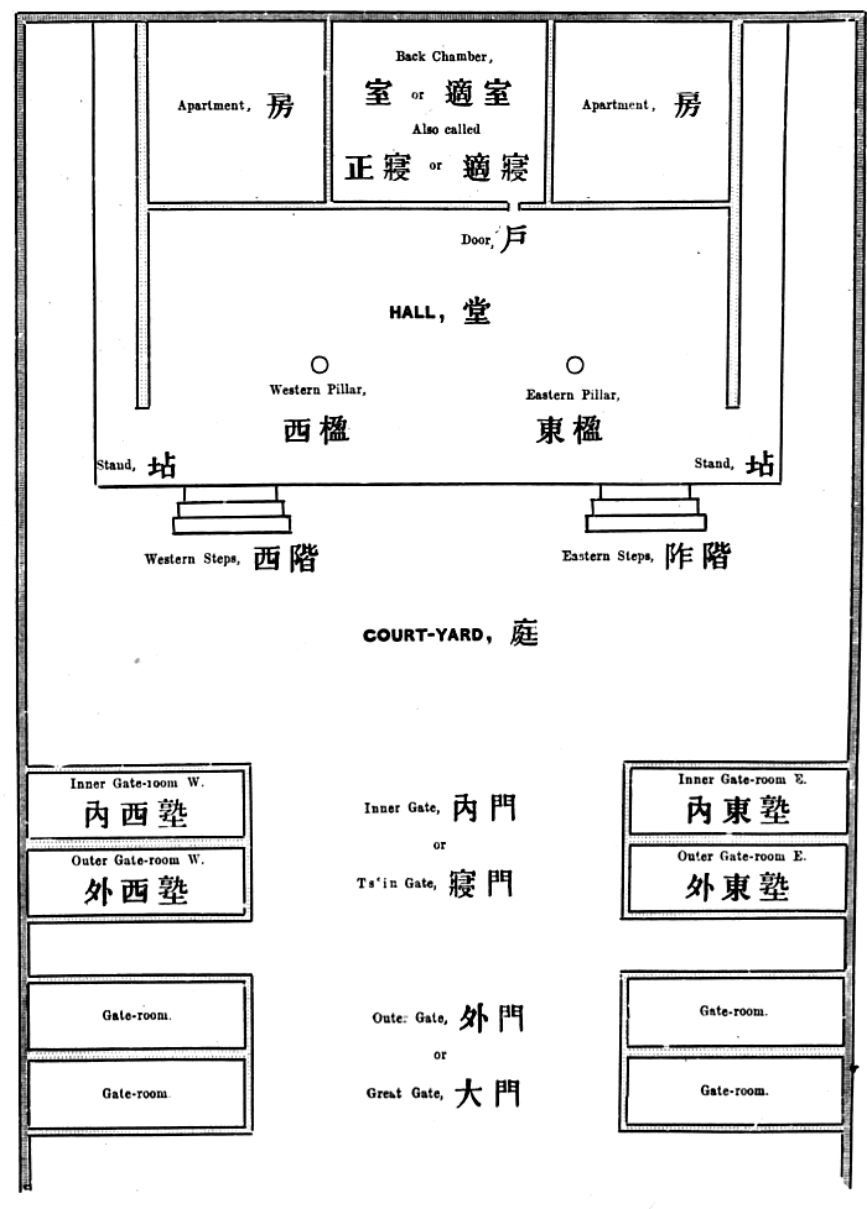

SOUTH.

PI. I. Plan of an official mansion during the Cheu dynasty. Walls are indicated by double lines.

feet, and double-caldrons 1 , all new, are washed clean at the foot of the western steps (107). The servant in charge of the apartments draws water, and without removing the rope from the bucket, coils it on his hand ${ }^{2}$. The Invoker (after the manner of the Hia dynasty) ${ }^{3}$ rinses

1 So called, because they were suspended on a wooden cross, which, looking like a double gallows, was styled 'a double'. We shall say more about it in Book II.

$2 \mathrm{He}$ had to use the rope again, having to go for water more than once.

3 In its chapters on funeral ceremonies, the I li makes frequent mention of Hia-chuh, Shang-chuh, and Cheu-chuh, or "Invokers after the manner of the Hia, Shang and Cheu dynasty", all of whom performed active parts in the proceedings connected with the disposal of the dead. But the informations the ancient books afford about the functions of those sacerdotal officers, are extremely scanty. The Cheu-li describes 


\section{The religious system of China \\ vol. I}

rice in the hall, turning his face southwards and using a water-basin (wherein to pour the rinsings) (108). While he performs this work, he separates, on filling the water-basin, the bad grains from the good ones (109).

The servant in charge of the apartments now ascends the whole flight of steps. Without going so far as the hall, he receives the rinsings and boils them on the furnace, employing a double-caldron. An attendant for the outer apartments occupied by the males accepts the thus prepared wash for the head and enters with it ; the principal mourners all leave the door to stand outside with their faces turned to the north, after which the head is washed, combed, and wiped with a towel. Subsequently, the p.18 body is washed with towels and wiped with bathing clothes (110), that is to say, the four attendants lift up the shroud, and so the washing is performed. There is then no mat upon the coach. At the death of an officer's mother, the washing is done by attendants of the inner apartments where the women live ; no hair-pin is in this case put in the coiffure (111).

The washing water is cast into the pit. The nails are pared and the beard trimmed as on other days (before death); the coiffure is bound with a tape and the hair-pin put into it. They then place the graveclothes on the body, the chief mourners finally entering and repairing to their places (112).

A similar account, very likely referring to Rulers and Great officers also, is given by the Li ki (ch. 57, I. 35 and 36 ). It runs as follows :

«The servant in charge of the apartments draws water. Without removing the rope from the bucket he coils it on his hand. He then ascends the whole flight of steps, and without going so far as the hall,

indeed, in its $25^{\text {th }}$ chapter, the functions of a Great invoker, a Sub-invoker, an Invoker for the Imperial hunting-parties, an Invoker for sworn conventions, and an Invoker for funeral rites, but it is quite uncertain whether there existed a relationship between them and the three functionaries mentioned above. In ch. 52 of the Li-ki (I. 8) we read : « The Invoker of the Ancestors regulates the rites in the ancestral temples, and the Invoker after the manner of the Shang dynasty the funeral ceremonies » (Sect. Io $\mathrm{Ki}, \mathrm{III})$, That Invoker of the Ancestors is generally supposed to have represented the office à la Cheu. 


\section{The religious system of China}

vol. I

hands the water to the attendants, who go in to wash the corpse. While four lower servants hold up the shroud, two attendants perform the washing. A basin is used for the washing water, a ladle to pour water over the body; the washing is performed by means of towels of fine dolichos, and in drying the body they use bathing clothes, just as in former days. A lower servant pares the toe-nails, and the rest of the washing water is thrown away into the pit. At the death of a mother, attendants of the inner apartments hold up the shroud and perform the washing.

The servant in charge of the apartments draws water again and hands it over to an attendant, who, separating the bad grains from the good, prepares, up in the hall, the water for washing the head. This wash is, in case of a Ruler, made of spiked millet, in that of a Great officer of panicled millet, in that of an p.19 ordinary officer also of spiked millet.

A furnace has been made at the foot of the wall on the west by the overseers of the waste and cultivated grounds, and double-caldrons have been brought out by servants in charge of the earthenware. The servant in charge of the apartment having now received the wash for the head, boils it (in the said caldrons, on the furnace), using fuel made of the stubble removed from the north-west side of the ancestral temple, and provided by the overseers of the waste and cultivated grounds. This done, the servant in charge of the apartments hands the washing water to the attendants, who thereupon wash the head, using an earthenware vessel for the purpose. The head is dried with a towel, as used to be done in former days; a lover servant clips the nails of the fingers and cuts the beard, and the washing water is thrown into the pit.

During the Cheu dynasty, other substances besides water and washings of rite and millet were, in the case of Rulers, used for cleansing the dead. We have ample evidence of this in the Cheu-li ${ }^{1}$.

1 Or "Ritual of the Chou dynasty". This is the third of what the Chinese call the San li "or Three Rituals", viz. the Li-ki, I li and Cheu-li. It contains a long series of descriptions of the functions and duties of the various officers during the Cheu dynasty, the whole thus giving a highly valuable picture of the organization of 


\section{The religious system of China}

vol. I

«p.20 When the sovereign dies, at the great exposition (of his body on the couch), the Underintendent of Religious Worship washes the corpse with fragrant spirits made from millet (113). - The Master of Collocation (whose function is to arrange the seats and implements at sacrifices), at great funerals, when the great washing with fragrant spirits takes place, puts up the cooking implements (114). - When, at a great funeral, the great washing of the body is performed, the Officer of the Millet-vine lays out the ladles and furnishes the milletwine for perfuming the corpse (115). - At a great funeral, immediately after the demise, the Great invoker washes the corpse with the milletspirits set out at the exposition of the body, assists in putting rice into the mouth of the dead, helps with the dressing, and removes and puts out the sacrificial implements (116). - And the Sub-invoker, at a great funeral, assists at the washing of the corpse, sets out scorched grain, and erects the banner which is inscribed with the name of the dead (117).

To return now to modern China, - in case the family should have the grave-clothes quite ready when the washing is over, they at once proceed to dressing the body in the way described in the next chapter. Otherwise they first leave the corpse in the clothes that were already put on it when death was imminent (see page 6), or change those clothes again, in each case, however, p.21 covering the body with a white shroud over which comes a red sheet of smaller dimensions. This hiding the dead from view is considered a

government in those ancient times. It is not a ritual work like the $I l i$ and $L i-k i$, but a constitutional one ; hence the original name Cheu-kwan, "Official Book of Cheu", was more correct than the present one, which dates from the Thang dynasty. We shah have to refer to the book very often in the course of our work.

A translation of the Cheu-li was made by Edward Biot, and published after his death at Paris, in 1851. We refer to this work those of our readers who are anxious to know more about a most remarkable legacy of antiquity. We are, however, sorry to say that we do by no means share the enthusiastic views, expressed by Dr. Legge about the book on page 5 of his translation of the $L i-k i$. The blunders in it are very numerous, though not the result of any disability to understand and analyse Chinese texts, but rather of the translator's want of a general knowledge of ancient China as depicted in the Classics. Indeed, he nowhere shows us that he has made a study of those works. Therefore, in giving extracts from the Cheu-li, we are in not one instance indebted to M. Biot, but have translated everything directly from the great Khienlung edition mentioned in the note on page 4 and bearing the title [..],"Report on the rules laid down in the Cheu-kwan, confirmed by imperial sanction". 


\section{The religious system of China \\ vol. I}

matter of great importance, because it represents a sacred custom handed down by holy antiquity. It is, indeed, mentioned by both the I li and the Li ki, as may be seen from the extracts quoted on page 18 ; moreover, the latter Classic (ch. 57, I. 34$)$ says :

«Immediately after the demise, the corpse is transferred (from the ground, see page 7) to the couch and covered with the shroud that is to be used also at the subsequent dressing; and the garments in which the last breath was drawn are taken off (118).

Placing a light near the corpse.

The $L i k i$ (ch. 57, I. 24) also has :

«In the case of a Ruler, there are two candles above in the hall and two below. In that of a Great officer, the numbers are respectively one and two, and in that of an ordinary officer, one and one (119).

And the I li says :

At night they light a torch in the central part of the court-yard (120).

The ancient custom, to which there passages introduce us, is also observed by modern Chinese down to the lowest classes. As soon as the deceased is stretched on the water-bed, one of the first cares of the family is to place a lighted candle in an ordinary candlestick near his feet, either on the couch or on a form or chair at the side of it. They call it a kha-bé-tsik or 'feet-candle'. Poor people in many cases take a bowl instead of a candle, put some sand in it and place upon the sand a small round open saucer of iron filled with oil in which a wick of waterrush is swimming. Such saucers, placed on a wooden stand, form the ordinary houselamps of daily life.

The usage, now under our notice, goes at Amoy by the name of ch'iō-ch'i, 'to light the corpse'. To properly understand it, one should bear in mind that since time immemorial the Chinese p.22 have divided nature in two great parts, supreme powers of the universe, one called Yang, embracing light, warmth, life ; the other known as Yin or the principle of darkness, cold and death. The former is more especially identified with the heavens, from which of course all light, warmth and life emanate ; the Yin, on the other hand, with 


\section{The religious system of China}

vol. I

the earth which, when not directly acted upon by the heavens, is nothing but a dark, cold, lifeless mass ; the regions of death also are an integrate part of it. Now, the disembodied soul being naturally under the full influences of those dark, unseen regions, would even in the broadest daylight be quite unable to find its way through them to the corpse and to the sacrifices which are to be offered there every day for its benefit, did not the family remedy the evil by the happy expedient which now occupies our attention. Besides, there is a second idea underlying the custom. Souls in general, constituting the vital principle of men, are in the main composed of material derived from Yang, the great source of all life in nature. With this idea before them and, moreover, convinced that the soul they are attending must be sadly weakened by its separation from the body, the family strengthen it by means of a little artificial Yang, to wit, by light and warmth emanating from the candle or the lamp.

This custom consequently acquaints us with a prevailing belief that disembodied souls continue wandering about the corpse, and enjoy the offerings that are made on the spot in their behalf. This idea should not be lost sight of by our readers, as it throws the fullest light on the whole extent of Chinese funeral rites and because the greater part of these would otherwise be perfectly unintelligible ${ }^{1}$.

1 The custom under our notice is also interesting from the fact, that it is paralleled everywhere in our hemisphere. The Christians in many parts of the globe surround the corpses of those lying in state with wax tapers, which they keep burning until the burial day. The Catholic church is known to be most particular on this point, as scarcely ever a funeral takes place without tapers round the coffin. Moresinus explains the use of the candle on this occasion as

« an Egyptian hieroglyphic for life, designed to express the ardent desire of the survivors to have had the life of the deceased prolonged.

In Levi's account of the rites and ceremonies of the modern Jews we have mention of the like practice. 'The corpse, he says, is taken and laid on the ground, and a light set at its head'. In Henry VIII's time it was the custom to set two burning candles over the dead body. Finally Pope's couplet will be familiar to the feeder of the pathetic story of Eloisa and Abelard -

Ah, hopeless lasting Flames! like those that burn

To light the dead, and warm th'unfruitful urn.

According to the Glossary to Maria Edgeworth's Castle Rackrent, in Ireland

« all the friends and neighbours of the deceased collect in a barn or stable, where the corpse is laid upon some boards or an unhinged door, supported upon stools, the face exposed, the rest of the body covered with a white sheet. Round the body are stuck in brass candlesticks, which have been borrowed perhaps at five miles distance, as many candles as the poor person can beg or borrow, observing 


\section{The religious system of China}

vol. I

p.23 Taking into consideration that the lamp in question is designed for saving the soul from starvation and evaporation, it will by no means appear surprising that all classes of the people connect a superstition with it to the effect that, whoever happens to extinguish it shall be visited by disaster. Indeed, the soul, roused to bitter indignation against such an increaser of its misery, will certainly make him bleed soundly for what he has done. Like woe shall betide the man who hastens the extinction of the lamp by allowing himself, even unconsciously, to be besmeared with some of the oil ; and there is nobody who, knowing himself the victim of such an atrocious deed, will rest until he has taken adequate revenge upon the low character who has thus exposed him to the anger of the soul. It is a matter of course that very near relatives are, in such cases, further beyond the reach of evil consequences than strangers, as they exert themselves with all the power that is in them for the welfare of the dead, and are liked for this by the soul.

Under the name ch'i-iû, 'corpse-oil', the luminiferous liquid of the lamp plays an important part in the black art. Women generally ascribe to it the power of creating discord between married people; hence many a principal wife, if jealous of a concubine who enjoys more of their common lord's love than herself, does not shrink from smearing the dangerous stuff on the garments of her rival, feeling sure she shall in this way put a stop to the good understanding which excites her jealousy. People also say that many women go so far as to lay up secretly a little quantity of such oil, in order to have it always ready at hand when required for bad purposes of the kind, e. $g$. in behalf of dear friends, who want p.24 a dose. It is quite natural that people who feel convinced that souls bear a deep grudge against any one who robs them of their oil, also believe that they strike wives, guilty of such an act, in the very first place in their matrimonial happiness ; in fact, nothing can be dearer to a Chinese woman, absolutely uneducated as she is to any feelings of higher order, than the animal affections of her husband. Besides, the oil,

always to have an odd number. » (Brand, Observations, pages 441 and 437).

"In the lowlands of Scotland a candle is waved thrice round a corpse as it is 'sained' or blessed. A candle used to be set upon a dead body in Northumberland, and a similar practice prevailed in the Isle of Man » (Denys, The Folk-lore of China, page 21). 


\section{The religious system of China}

vol. I

symbolizing the separation of the dead from the living, cannot but have a separating influence on a couple who are brought in close contact with it.

They place paper slaves near the corpse.

So far for the candle and the lamp. As the family sagely surmise that the soul wants servants in the world of darkness too, they place two puppets near the feet of the dead, either upon or by the water-bed. These puppets, made in the roughest possible manner of paper pasted on bamboo splints, are not more than a foot in size ; they represent one male and one female, and are known as kha-bé kán, 'feet-slaves'. Afterwards they are placed in the coffin at the feet of the dead.

They collect ashes at their neighbours.

As soon as the washing of the corpse is over, the sons, in their sackcloth garments, once more leave the house, this time carrying an ordinary basket, in which they have placed a rice-measure upside down. They go out for what they call khit hé-hu, 'begging for ashes'. Each laying one hand on the basket, they slowly and solemnly repair to the next dwelling and kneeling down in front of the entrance, their eyes silently fixed on the pavement, patiently wait for the master, who soon appears and places some ashes from his kitchen on the turned-up bottom of the measure. In return for this gift the eldest son silently hands a couple of candles to him, intended to be burned upon his domestic altar. This done, the mourners resort to the house of a second neighbour and even to a third, there going through the same ceremony, and finally they return home. Whilst performing these acts of filial devotion the mourners do not wail, as it is rude, nay cruel and criminal, to bring influences of mourning over other people by pouring out lamentations on their premises.

p.25 If the deceased has no sons living, the ashes are collected by the next-of-kin, in accordance with the classification of rank recognized in Chinese family-life, just as in the case of buying water for washing the corpse (page 14). The ashes are designed for the equipment of the coffin and shall, as such, be spoken of again in chapter $\mathrm{V}$. 


\section{The religious system of China}

vol. I

They remove the furniture, sleep on straw, etc.

Meanwhile, the part of the dwelling which is the principal scene of the funeral rites, has been made to undergo an important change. The altar with the ancestral tablets and the images of the domestic divinities was, as we said on page 5, removed from the hall when death was imminent or seemed to be so. But as soon as life is actually extinct, the same measure is extended to the whole of the furniture including the two lanterns, with censer betwixt them, that in fashionable houses hang down from the ceiling in honour of the spirits presiding over heaven, earth, and water, or the so-called Sam-kàikong, 'Lords of the three Spheres'. The paper scrolls inscribed with antithetical sentences, that ornament the walls by pairs, are taken down, and so are the pictures of landscapes and scenes of domestic life, the pieces of red cloth fixed over the lintels of the doors and windows to keep out pernicious influences, etc. Etc. Only a few stools or chairs are left for the convenience of condoling visitors, as the rules of etiquette forbid the receiving of the same without offering them a seat.

Thus the water-bed with its appurtenances is about the only thing to be seen in the hall. In many cases, a small movable furnace, called kim-lô, or 'furnace to burn gold', is placed on the floor in front of it, and made to consume from time to time a quantity of small paper sheets which kinsmen, friends and acquaintances, on calling to condole with the family, offer for the purpose. These sheets, being all partly tinned over on one side, are, according to the prevailing conviction, turned by the process of fire into real silver currency available in the world of darkness, and sent there through the smoke to the soul ; they are called gûn-tsoá, 'silver paper'. Most families prefer to previously fold every sheet in the shape of a hollow ingot, a 'silver ingot' gûn-khò, as they call it. This p.26 requires a great amount of labour and time, but increases the value of the treasure immensely. It is also customary to add to every portion burnt a number of such sheets coloured yellow with a decoction of certain flowers, to represent gold. This 'gold paper' kim-tsoá is likewise folded beforehand into what they call 'ingots of gold' kim-khò, but it is designed for the benefit of the local divinity of the Soil, the patron divinity of departed souls of whom more will soon be told. By the way it remains to be 


\section{The religious system of China}

vol. I

said, that in many cases a furnace is dispensed with for the paper-offerings, everything being simply burned on the bare floor.

The hall thus strongly reminds us of very ancient, not to say savage times, when all the possessions of the dead man were thrown into a fire, kindled for the purpose by the side of the corpse. There are, indeed, many instances on record of uncivilized tribes that burn or otherwise destroy their property, the implication being that the things themselves, or their ghostly duplicates, go with the soul into the other world.

«In Africa this is common : among the Koosas the widows of chiefs burn all the household utensils; the Bagos (Coast Negroes) do the like, and include all their stores of food ; even their rice is not saved from the flames. It is a custom of the Comanches to burn the deceased's weapons. In other cases the dead man's implements and movables are broken. Franklin says of the Chippewayans, "no article is spared by these unhappy men when a near relative dies; their clothes and tents are cut to pieces, their guns broken, and every other weapon rendered useless" (121).

Now, on seeing that the modern Chinese convert a great deal of their possessions into mock paper money and, as we shall have occasion to describe in subsequent chapters, also into paper-and-bamboo models of houses, furniture and other necessaries of life, finally turning the whole collection into smoke and ashes for the dead man's use, it is certainly not against the laws of logic to believe we have here to do with a survival of a more ancient destruction of real property.

Conjecture, in fact, seems useless to establish a reason for this custom, and for many others that fall under our notice in this part of our work, unless we trace them back to such ancient times. As will be discussed in extenso in the $6^{\text {th }}$ and $7^{\text {th }}$ chapters of the third part of this Book, the ancient documents of the empire afford the p.27 fullest possible evidence that, originally, mourning was nothing but an absolute renunciation of all earthly goods for the sake of the dead, and such on account of a dominating principle that everything a child possessed was its father's property and continued to be so after the latter's translation to the other world. Even at the present day this 


\section{The religious system of China \\ vol. I}

dogma reigns supreme in Chinese society. Anciently it prompted the offspring to fill up the tomb with all sorts of implements, ornaments, rare and precious objects, domestic animals, even to bury the deceased's wives, concubines and slaves: the two paper slaves spoken of on page 24 undoubtedly represent a last faint shadow of this practice ${ }^{1}$. Indeed, nothing was kept by the mourners to cover their limbs but the poorest sackcloth perfectly valueless to the deceased, whom they dressed, on the other hand, in the most costly robes they could afford : the same sackcloth is still found on the bodies of modern mourners at the more important phases of the funeral rites. Finally, the ancient books teach us that the mourners observed a rigid fasting and ate nothing but a small quantity of water-gruel now and then, all the food in the house having to be sacrificed to the deceased 2 ; so, cooking was given up, and the ashes required for the coffin had to be applied for at the neighbours. It is true that fasting has now nearly disappeared from the funeral rites, but the custom of begging for ashes has, as we have shown on page 24 , been devoutly maintained as a solemn rite down to the present day. It will be perfectly clear now why the persons who perform it wear the sackcloth garments.

The custom of removing all the furniture from the hall in which the dead body lies, we may now consider as sufficiently explained. No doubt there is a close connexion between it and this ancient prescript occurring in chapter 4 of the Li ki (I. 2) : « He who has suffered a loss by death sits on a single mat ». But even more is done now-a-days as long as the body is uncoffined: the wife, sons, daughters, daughters-in-law, and the eldest grandson renounce their beds also, and pass their nights by the side of the corpse on a mat or some straw spread out on the floor. This usage, which goes by the term tsiú si, 'to watch over the corpse', is p.28 likewise of very ancient standing : in fact, in the China of ancient times the mourners used to occupy small sheds of wood and clay, specially erected for the purpose and entirely without furniture of any kind, there to spend the days in wailing and fasting, their

\footnotetext{
1 This subject will be amply dealt with in the $4^{\text {th }}, 8^{\text {th }}$ and $9^{\text {th }}$ chapters of the third part of this Book.

2 A special chapter, the $7^{\text {th }}$, will be devoted to this subject in the third part of this Book.
} 


\section{The religious system of China}

vol. I

nights on straw or matting "with a clod of earth for a pillow". All this will be treated of at length in the sixth chapter of the third part of this Book and illustrated by extracts from ancient native works. That the modern mourners lie down in the immediate vicinity of the corpse with the professed design to watch over it, resembles our own practice of watching the dead ${ }^{1}$.

Even on its outside the house of mourning is stripped of its ornaments. The inscriptions on long strips of red paper, affixed along the door-posts and over the lintel of every Chinese dwelling, are pasted over, or partly pasted over, with a white or black paper band bearing no characters at all, and a like band is made to cover the inscriptions or painted human figures that decorate each door-leaf of the main entrance. Mourning, indeed, allows of neither paint nor colour and is especially inconsistent with red, because this colour is believed to expel pernicious influences and thus particularly to symbolize good luck, happiness, delight and pleasure.

The most conspicuous intimation to passers-by that some one in the house has departed this life, is a sedan-chair of bamboo splints and paper, placed outside the door for the use of the soul. It goes by the name of kèsoa $^{n}$ kiō, 'palankeen to cross the country'. Its dimensions vary from two feet to the ordinary size, and are proportionate to the means of the family. The carrying poles are affixed on the shoulders of two or four human images, likewise made of bamboo and paper. As these beings are appointed to convey the soul on their shoulders wherever it should desire to go, and thus to save it all physical fatigues in the realm of shades, the surviving p.29 relatives, of course, take good care to propitiate them, lest they should fall short in their duty and prove intractable and lazy. Each of them is regularly refreshed with a tea-cup of cooked rice and a few cakes, one of the kinsmen inviting them with bows and holding a few incense-sticks between his fingers, to partake of

1 Brand, quoting several authorities, points out the existence of the custom of watching the dead, also in very ancient times, in the north of England, where it survives under the name of lake-wake, in North Wales, where it goes by the name of wyl-nös, in Cumberland, in Ireland, in the Isle of Man, in Sweden, and observes : «That watching with the corpse was an ancient custom everywhere practised, numerous passages from ecclesiastical writers might be cited to prove, could there be any doubt of the antiquity of a practice which, owing its origin to the tenderest affections of human nature, has perhaps on that account been used from the infancy of Time » ("Observations", p. 437 and 462). 


\section{The religious system of China}

vol. I

the food ; moreover, a few threaded sheets of mock money are hung round the neck or on the arm of each, every Chinaman knowing by experience that chair-bearers are always strongly opposed to moving when no advance wages have been paid them.

By the way it may be mentioned here that the well to do sometimes have, during the funeral rites, a kind of awning, constructed of bamboo poles and white cloth or matting in their court-yard in front of the hall. It is designed for affording protection against rain and sunshine to all those who take a part in the preparation of the body for the grave and in the funeral rites.

Placing food at the side of the corpse.

At the beginning of the second chapter describing the Chinese practice of wailingly calling to the dead, we saw in it an attempt to induce the soul to return and re-animate the corpse, an attempt pointing to a prevailing belief that death is by no means absolute, but may, like other insensibilities, be only temporary. This belief has created another custom, to which we must devote a few moments of attention, to wit, that of feeding the corpse by actually putting food into its mouth and placing eatables by its side.

As filling the mouth of the dead with morsels has now well-nigh fallen into disuse in Amoy and its environs, the custom can only be dealt with in its historical aspects and is consequently reserved for discussion in the $7^{\text {th }}$ chapter of the second part of this Book. But setting out food at the side of the corpse is still faithfully observed by all classes of society as a holy customary law allowing of no infringement whatever.

Before taking their usual breakfast, the deceased's wife and children arrange a bowl of cooked rice, and in many cases also a dish of vegetables, bean-curd or the like, on a table at the right hand side of the bed. They carefully add a pair of chop-sticks, the well-known instruments that serve the Chinese to conduct their food to their mouths. Then taking burning incensesticks between their fingers, they kneel down on the floor and wail and lament for a few minutes in the usual way, some silver mock money being in the meantime kindled in the furnace to enrich p.30 the dead. And after a time, when the deceased is supposed to have satisfied the wants of his stomach, 


\section{The religious system of China}

vol. I

the mourners proceed to take their own meal, consuming in most cases the food offered to the corpse ; but in some families they prefer giving that food to the beggars in the street, as the influences of death which stick to it might perhaps injure them.

This giving the corpse food is a custom of very ancient date, traceable in the old documents of Chinese literature. It will likewise be treated of in ch. 7 of Part II.

Sacrificing to the local divinity of the Soil.

A petty offering, also composed of a bowl of rice to which a few dainties are added occasionally, is at the same time set out for the use of the local divinity of the Soil, whose acquaintance the reader has made on page 26 . If properly propitiated in this way, this being is expected to safely pilot the soul through the regions of darkness, of which he has the control. It is the duty of one of the mourners to invite him to help himself; for this purpose the man makes a polite bow in front of the offerings, at the same time holding one or three burning incense-sticks in his joined hands on a level with his head. Prudent and intelligent people take care to lay out only one chopstick for the use of the god, thoughtfully calculating that it must take him in this way a long time to consume his meal and so prevent him from hurrying off before the soul is properly prepared to follow him.

Visits of condolence.

On pages 9 and 25 we cursorily noticed the fact that kinsmen, friends and acquaintances are in the habit of calling at the house of death to present their condolences to the afflicted family. This is called bāi song, 'to inquire after the decease'.

When such a visitor has entered the hall, he kneels down in front of the curtain which screens the corpse from view, lays his forehead on the ground and wails a moment or two in this position in concert with the mourners, who have retired for this purpose into the side apartments. The principal mourner then makes his appearance, silently prostrates himself before the visitor and knocks his head against the floor at least three times, thus ${ }_{\text {p. } 31}$ expressing the 


\section{The religious system of China}

vol. I

thanks of the family for his having come to take part in their grief. The guest now pronounces a few words of endearment and consolation to the mourner, and, in return for his present of mock paper money which has been brought in by a servant a few moments before, he receives a little skein of thin red cords of silk, a piece of white linen, and a piece of red silk or cotton, of which articles the family have purchased a good quantity beforehand with a view to the expected guests. The white and the red cloth are designed for a mourning band, which the visitor will have to wind around his head in the funeral procession in case he might wish to accompany the corpse to the grave ; the red threads, however, are fastened forthwith to the lapel of his coat, red being supposed to counteract pernicious influences in general, and those which result from contact with death and mourning in particular.

The guest thereupon retiring, the family take care to pay the bearers of his palankeen their full wages for the journey out and home. Indeed, the Chinese rules of etiquette severely forbid one who enjoys the honour of a ceremonial call to allow the party who bestows the honour, to pay the expenses connected with it.

Whenever a relation appears who, according to prevailing social notions, occupies a higher rank in the hierarchy of the family than the mourners, as their paternal uncle, or a brother of their grandfather, it is necessary for all the sons of the deceased to come forth simultaneously, in order to thank him with prostrations for his call. There are always some among the visitors, more especially among the female part, who remain with the mourners to lend them a helping hand in the preparations for the burial.

Presenting paper money when paying a visit of condolence is a custom firmly established, and accordingly complied with by everybody with great strictness. The quantity and value of each one's gift is duly set down in a special memorandum book, it being highly desirable for the family to be able to calculate after the rites are over, how large a quantity of sacrificial articles ought to be sent to each visitor in return. The paper is designed for the equipment of the coffin and, accordingly, always denoted by the term koanthaô tsoá, 'coffin-paper'. But as the receptacle of the dead is, of course, not spacious enough to hold the whole mass offered by so many friends, it is 


\section{The religious system of China \\ vol. I}

regularly burned by lots by p.32 the side of the corpse, as was said already on page 25, the ashes being carefully collected to be afterwards wrapped in paper and placed in the coffin, or at the side of the coffin, in the tomb.

Relatives and friends living at a considerable distance and, on this account, unable to call in person, are allowed by custom to depute a servant or hired messenger to bring paper money to the house of mourning. The family then commit the cloth and the skein to the hands of this man, ordering him to take them to his employer; they also pay him his wages for the message out and home in obedience to a like rule of etiquette which prescribes payment of the chair-bearers of visitors. It may, of course, occur that such a messenger, on his way to the house of mourning, receives intelligence that the corpse has been coffined in the mean time and the coffin closed. In this case, he is not allowed to take the paper back, neither to deliver it, Tzĕ-yiu, a disciple of Confucius, having declared on a certain occasion, that «in funeral matters there should be a regular progress, no retrogressive movement 》 (122) ; so, to help himself out of the dilemma, he stealthily throws the paper into the premises of the mortuary house, or over the wall into the court-yard. Indeed, now it is neither offered nor taken back the way it had come, and full justice is done to the doctrine of the ancient sage.

Women in the family way are scarcely ever allowed to pay visits of condolence, their husbands wisely calculating that, whereas death is diametrically opposed to life, contact with funeral rites must badly injure the child in utero and a miscarriage be the consequence. Perhaps the Chinese are not on this point under the influence of sophisticated reasonings only, for they can scarcely have failed to observe, that the disagreeable emotions of a future mother are often far from remaining without effect upon the foetus.

It is a general conviction that any one who calls at a mortuary house incurs a kind of pollution, especially so if death has been untimely or caused by disease. Some condolers therefore wisely hide a few garlic roots under their garments, convinced that the strong smell will prevent the influences of death from clutching to their bodies; on leaving the house they throw the roots away in the street. Others, on re-entering their dwelling, purify 


\section{The religious system of China \\ vol. I}

themselves by stepping over a fire, or over some burning incense powder of a

kind considered especially suitable for this and similar ends and p.33 therefore styled tsing hiung, 'purification-incense'. Those who are of a rather orthodox turn of mind feel convinced that, unless such a cleansing has been properly undergone, it would be revoltingly irreverent to worship the God of Heaven until a certain number of days have elapsed ; under no pretext whatever will they venture to perform to that supreme divinity of the pantheon the ordinary acts of daily homage which consist in placing, at sunset, a few incense-sticks in the doorposts outside the dwelling and, at the same time, a burning candle in the so-called 'lantern of Heaven' thien ting suspended near the spot. Some go even so far as to abstain from all worship to any divinity whatever for a certain length of time, the duration of which depends upon the degree of their own superstition.

The above description of the visits of condolence in modern China remind us again of a set of remarkable practices directly inherited from high antiquity. The ancient books of rites teach us that, during the Cheu dynasty, even sovereigns and potentates were in the habit of sending messages of condolence at the death of their officers, also of going in person to the house of mourning. Their consorts acted in a similar manner; noblemen and grandees attended part of the funeral rites of their colleagues, not excluding those of lower rank; everybody, from the very Ruler down to remote kinsmen and friends of the deceased, presented grave clothes, obviously the forerunners of the modern 'coffin-paper'. Even the curious idea that pollution is incurred by such visits was strongly entertained in those times. We will now pass in review the principal passages bearing on this subject.

The $I$ li says in its chapters on the funeral rites of ordinary officers :

« The Ruler sends a man to condole with the mourners. The curtain (suspended in the hall to screen the back-chamber from view) is tucked up, and the principal mourner receives the man outside the ts'in gate, but he does not wail on seeing the visitor. He then precedes him in entering the gate, turns to the right, and stands there with his face towards the north. 


\section{The religious system of China \\ vol. I}

The condoler, after entering, ascends the western steps and places himself with his face eastward, whereupon the principal mourner advances to the middle of the courtyard, and the condoler delivers his message. This done, the principal mourner wails, p.34 bows, knocks his forehead against the ground, and performs a full stamping (consisting of three stamps with the feet, thrice repeated). ; the visitor then leaves the gate, and the principal mourner bowingly sees him off outside the outer gate ( $\underline{123})$.

« The Ruler sends a man to bring grave clothes. The curtain having been tucked up, the principal mourner acts as in the foregoing case. The messenger with the clothes, holding the collars with his left hand and the waists with his right, enters, ascends the steps, and delivers his message, the principal mourner making his reverences as in the last case. The man with the clothes then enters (the back-chamber) and places the clothes on the corpse; this done, he leaves the gate and is bowingly seen off by the principal mourner as in the case before-mentioned.

«Only if a message comes from a Ruler, the principal mourner appears (from the back-chamber, to receive it). But when he ascends or descends the western steps, he makes reverences to the visitors (that happen to be present at that moment). If there is a Great officer, he makes reverences to him separately from the others and places himself at the foot of the western steps with his face to the east, but he does not stamp his feet and enters the back-chamber again even though the Great officer has not told him to go (124). He has, of course, to show the utmost anxiety to be at the side of his father's corpse.

The near relatives (uncles, aunts, sisters and so on of the dead) present grave garments. They do not deliver a message with them, but lay out the clothes immediately (in the apartment on the east-side of the back-chamber).

p.35 The several kinsmen present grave clothes, but through messengers who have to deliver an address in the back-chamber. The 


\section{The religious system of China}

vol. I

principal mourner makes reverences to them from the place assigned to him, whereupon the clothes are deposited on the east-side of the corpse, upon a couch.

The friends present grave clothes. They bring them in person; the principal mourner bows to them, and they put down the garments as in the last instance.

And when (such a messenger or friend) retires, the principal mourner wails, but without stamping his feet (125).

In chapter 58 (leaf 26) of the Li ki we read :

In the case of a Great officer or his principal wife of the same surname as the Ruler's, the Ruler attends at the fuller dressing, but if he wants to show a special favour to the dead, he attends at the slighter dressing too. At the rites for a Great officer's principal wife having a surname different from the Ruler's, the Ruler arrives after the lid is placed on the coffin ; at those for an ordinary officer, he goes after the coffin has been stored away in the hall, but if he wishes to show a special favour, he attends at the fuller dressing.

And as to his consort : - at the rites for a Great officer's principal wife, she goes to see the fuller dressing, but if she wishes to show favour, she attends at the slighter too. In the case of any other of his women (including sisters and other females of the same surname), she attends at the fuller dressing if she wants to show a special favour ; but at the death of a Great officer's principal wife having a surname different from hers (or her husband's ?), she goes there when the coffin has been stored away.

p.36 The fact that the visits of condolence were regulated by such subtile rules of etiquette affords another instance that such visits were paid on a most extensive scale. The higher the rank of the deceased or his repute with the Ruler, the earlier the latter arrived, and the greater the number of the rites attended by him. For the better understanding of the above extract we may inform the reader, that the dressing of a corpse used to be done in three stages : first, they put on the body-clothes and a few suits besides; then 


\section{The religious system of China}

vol. I

they performed the 'slighter dressing', for which a great number of suits were taken, and finally came the 'greater or fuller dressing', immediately followed by the coffining and the storing away or setting by of the dead against the western wall of the hall. All these parts of the ancient funeral rites will be properly reviewed in the second part of this Book, ch. $V, 1$, and in the third part, ch. I.

Of such a visit paid by the Ruler in person at the death of an ordinary officer to whom he wanted to show a special favour, we find an exhaustive description in chapter 28 of the $I$ li. (I. 24-34) (126).

«If the Ruler wishes to show a favour, he comes to see the (fuller) dressing. After the clothes have been laid out, he arrives, the principal mourner leaving the house to receive him outside the outer gate. As soon as he sees the heads of the horses, the mourner puts a stop to his wailing, turns round, passes through both the gates, turns to the right, and takes his station with his face to the north, baring the upper part of his body in concert with all the principal mourners.

The Exorcist (of the Ruler) does not go further than the outside of the temple-gate (i. e. the ts'in gate), the Invoker coming in his stead at the head of the procession. Two lower servants with lances march ahead of the Ruler, and two in his rear. Having set out vegetable offerings (to the spirits of the gates) the Ruler passes p.37 through the gates, while the principal mourner withdraws to his place.

Ascending by the eastern steps, the Ruler takes his station (in the eastern part of the hall), with his face towards the west, (thus seeing the corpse stretched on a coach in the centre of the hall). His Invoker places himself with his back against the wall and with his face towards the south, while the principal mourner stays in the centre of the courtyard.

Now the Ruler wails. The principal mourner, having wailed also, salutes the Ruler by laying his forehead to the ground, then he performs a complete stamping of the feet ${ }^{1}$ and goes out of the gate (as if

\footnotetext{
1 Three stamps, thrice repeated.
} 


\section{The religious system of China}

vol. I

expecting the Ruler to leave now, in which case he would have to reverently see him off). But the Ruler orders him back and the business of dressing to go on, whereupon the principal mourner returns to his place (on the east of the gate, in the courtyard). He is ordered, however, by the Ruler to come up by the steps ; and he takes his station on the east of the western pillar, facing the north.

After the feudal Rulers, high nobles and Great officers have been likewise ordered up the steps (by the Ruler), and have arrayed themselves behind the principal mourner, the highest amongst them on the east-side, the dressing is performed. When over, the dukes, high nobles and Great officers descend in reversed order (from that in which they came up the steps), and return to their places (in the south-east corner of the courtyard). The principal mourner now goes down also and leaves the gate (as if hastening again to see the Ruler off), but the Ruler orders him to come back once more, upon which he resumes his place in the centre of the courtyard.

The Ruler now sits down and places his hand on the bosom of the dead. The principal mourner lays his forehead against the p.38 ground, performs a complete stamping with his feet, and runs out of the gate again. Being ordered back, however, by the Ruler, he returns to his old place (inside the gate, on the east of the courtyard), while the other principal mourners retire under the eastern wall, where they stand facing the south.

The Ruler, upon this, descends by the steps, stands (for a moment) with his face westwards, and orders the principal mourner to lean on the corpse. Ascending by the western steps and passing by the feet of the corpse, the latter leans on the body with his face towards the west, not touching, however, the place which the Ruler occupied (when laying his hand on the corpse). When he has stamped his feet, the principal female mourner, facing the east (and accordingly standing on the west-side of the couch), leans on the corpse also like the principal mourner. 


\section{The religious system of China \\ vol. I}

Now the corpse is lifted up and put into the coffin. This is thereupon closed; the principal mourner goes down the steps and leaves the gate, but the Ruler orders him to return. He re-enters, turns to the left, and watches the plastering of the coffin. The Ruler goes up by the steps and repairs to his place, while the principal mourners resume theirs also.

The plastering finished, the chief mourner leaves the gate, the Ruler, however, ordering him back to have the sacrificial articles presented. After the mourner has entered again and gone to the right hand side of the courtyard, the offerings are set out, the same being taken up by the western steps. The Ruler stamps his feet when the time to do so comes, the principal mourner imitating him in this ; and, the off rings placed, the latter leaves the gate. While the wailers make a pause, the Ruler goes out by the gate also. On passing through that of the temple (i. e. the ts'in gate) he wails, but the principal mourner does not wail with him. The latter then steps aside; the Ruler makes a bow to him, and when (at the great gate) he has got into his p.39 carriage of second rank, the principal mourner wails and bowingly aces him off.

The mourner then adjusts his clothes again on the upper part of his body, re-enters the gate, and repairs to his place (at the foot of the eastern steps, on the east). The other principal mourners likewise adjust their dress. He then makes reverences to the Great officers, who came in after the Ruler, and performs a complete stamping of the feet. The guests now retire, the principal mourner seeing them off with bows.

So far goes the I li's account of the way in which the princes of antiquity honoured the funeral of their officers by their presence. That the family felt greatly honoured by such visits need not be said. The chief mourner's way of expressing this by frequently running to the gate to see the high visitor off is no doubt understood by the reader to have merely been an act of etiquette meaning to say: "We have been now honoured by your presence as much as we might possibly hope for, and dare by no means expect you to remain one single moment longer in our midst". 


\section{The religious system of China}

vol. I

Another act of great importance was the imposition of hands. It implied great reverence for the dead, hence we find it minutely regulated in the ancient rites by rescripts.

"The Ruler", says chapter 58 of the Li ki (leaf 16) (127), lays his hand on a Great officer and on his own principal wife ; a Great officer does so on his palace-elder, on his niece and his brother's wife. A Ruler and a Great officer lean on the bodies of their parents, wife and eldest son, but not on those of their other sons; an ordinary officer leans on his parents, wives, eldest son and other sons. If such a son but the eldest has a son, then his parents do not lean on his body. The parents of the dead do it prior to the man who generally performs the ceremony (i. e. the principal mourner), and the wife and sons after him.

p.40 A Ruler lays his hands on the bosom of his minister. A father and mother hold (the dress on the breast of) their child with their hands, but a child leans over the body of its father or mother. A woman pulls up the dress (on the breast) of her father-in-law or mother-in-law, but a father-in-law and mother-in-law only lay the hand on the bosom of the woman. A wife grasps the dress of her husband firmly, but a husband merely holds that of his wife and his own brother with his hands.

On leaning over a corpse, the spot which the Ruler occupied on doing the same thing may not be trodden on. And every one who performs the act must, on rising, surely stamp his feet.

So, leaning over a corpse implied the deepest sorrow and affection, merely imposing the hands, the slightest. Between these two extremes lay consecutively : pulling up the dress at the breast, grasping it firmly with the hands, and merely holding it in the hands.

A few words now remain to be said on the Exorcist and the Invoker, who escorted the Ruler on his visit. We may not pass these men by in silence, as they distinctly point to the existence in those ancient times of similar ideas on pollution by contact with death as we have found prevalent at the present day (page 32). 


\section{The religious system of China \\ vol. I}

Exorcists are, under the name of $\mathrm{Wu}$, very frequently mentioned in ancient Chinese literature. Already the Shu king makes distinct mention of them. By collating all the passages relating to them, it is seen that they were a certain class of priests and priestesses entirely possessed by spirits of Yang material (comp. page 22) and, as such, were deemed especially fitted to perform chiefly three several functions : (1) to call upon the spirits of the p.41 dead in order to make them partake of offerings ; 2 ) to foretell future events by interrogating the spirits and communicating their will to the living ; (3) to expel diseases and evil in general, especially droughts, by neutralizing through the Yang power residing in their persons the influence of the element of darkness Yin (comp. page 22) and the evil spirits that are identified with it. Now, it is in this last quality that we see them in the retinue of the ancient Chinese potentates when about to expose themselves in a house of death to the attacks of invisible agencies. Commenting on the passage referring to the Exorcist in the above extract from the $I$ li, the learned Ngao Ki-kung of the Yuen dynasty says indeed :

« Certainly a Wu and an Invoker were employed by him because he had also to come in contact with the ghost.

Chapter 12 of the Li Ki says on leaf 46 :

«When a Ruler goes to the funeral rites of a minister, he has with him a Wu and an Invoker holding respectively a piece of peach wood and reeds, as also lancers - because he dislikes (the influences of death). »

« The peach tree, says Ching Khang-ch'ing, the most famous of all the commentators on the books of rites, who lived in the second century, is dreaded by ghosts, and bundles of reeds are available for sweeping inauspicious things away ; - they were used then because there were inauspicious and evil influences about.

It is a pity that the books say nothing about the doings of those men on that occasion, for it can scarcely be doubted that they performed many superstitious rites during the Ruler's visit, or at the moment of his arrival and departure. The Cheu li says in the $25^{\text {th }}$ chapter, on leaves 30 and 39 (128) : 


\section{The religious system of China \\ vol. I}

«When the Sovereign pays a visit of condolence, the Invoker for the funeral rites marches in front of him in company of the $\mathrm{Wu}$

and

« The male $\mathrm{Wu}$ on the same occasion walks ahead of him with the Invoker,

p.42 but no noteworthy information whatever is afforded by any of the books of rites. Turning over the pages of the Tso ch'wen, the well-known commentary of Tso Khiu-ming on Confucius' Ch'un ts'iu, we find under the heading $29^{\text {th }}$ year of duke Shang (B. C. 543) (129) :

« The people of Ch'u required the duke to bring grave clothes in his own person (for their king Khang). He disliked doing so, but Muh-shuh said : "Have the inauspicious influences driven away from the place in the hall where the coffin is stored away awaiting burial, and then take the grave clothes thither : they will then be mere (harmless) cloth and silk". Accordingly a Wu was dispatched first to dispel such influences from the spot by means of peach wood and reeds, which the people of Chu did not prevent ; but after it had been done, they were sorry for it.

It follows from this, that the practice had already in those early times fallen into same discredit; indeed, though highly salutary for the safety of the Ruler's holy person, it could not but be looked upon as rather insulting to the dead person against whom it was directed.

There are many more references to visits of condolence in $L i k i$; but as they tell nothing new worthy of notice, and the important part of such visits in ancient Chinese life has been sufficiently illustrated by the above lengthy quotations, we abstain from reproducing those passages. Considering now that even at the present day scarcely anybody related to the deceased or the mourners would dare to fail in going up to the house of death, in order to discharge himself of what he deems a holy duty on his part, it may be taken for granted that in the entire succession of generations lying between ancient and modern China, such visits have formed an inseparable, nay, an integrate part of the range of social customs. It would lead us too far from our subject to confirm this, if confirmation were necessary, by long quotations from the 


\section{The religious system of China}

vol. I

native literature. Let a single extract suffice for the purpose. It is taken from the sixth section of the Yen-shi kia hiun ${ }^{1}$ or p.43 "Domestic Instructions by Mr. Yen", a highly interesting ethical work of the sixth century, treating of the rules of conduct to be observed in domestic life.

«In the countries south of the Yang-tszĕ, at every heavy loss by decease, connections with acquaintances living in the same town are broken off, if they do not pay a visit of condolence within three days after the death. And even on coming across them when the mourning rites are over, all contact is avoided, owing to the grudge entertained against them for not having shown sympathy. Those who have an excuse, or a long way to go, are allowed to send a letter, and if they neglect to do this, they also are dealt with in the same way. In the north there are no such customs.

\section{Precautions against cats.}

A few superstitious notions and customs relative to the dead have still to be dealt with before concluding this chapter. As soon as the last breath has been drawn, the family at once manifest a great anxiety to transfer all the house cats to the neighbours, or, at least, to tie them fast and not release them again in their own horse until the coffining is over. In fact, if Pussy were not secured, it might occur to her to leap or walk over the dead-bed, and so cause the corpse to rise up at once. A long pole would, in this case, be required to push it down into its former position, or a piece of furniture would have to be used as a projectile, though nothing can serve the purpose so well as a broom. The handle, namely, renders it eminently fit for being grasped with the hands, so that the corpse, frantic with rage, will pull the broom at once against its breast to cool its wrath upon it, and by this vehement motion sink down into its inert state. That it is far from advisable to expose one's self to the danger of being seized instead of the broom, we need not say : a horrible death in a ferocious embrace would be the inevitable consequence.

To account for this curious superstition it is necessary to dwell p.44 for a moment on the domain of tiger-lore. A tiger, the Chinese say, has on its tail a

\footnotetext{
1 The full name of the author is yen Chi-thui.
} 


\section{The religious system of China}

vol. I

very miraculous hair, endowed with the power of bringing the soul back into any human body which lies motionless and insensible; it is known by the popular term of hoân hûn mńg, "hair that causes the soul to return". Now, whenever the monster has dragged a man into a mountain recess, it takes good care first to wag its tail all round and over him, knowing by experience that the unfortunate victim, on returning to life, will in his second agony of death, stupidly tear off his clothes and thus enable his assailant to eat him without being incommoded by troublesome shreds and threads. Moreover, the Chinese are very well aware that the cat resembles the tiger not merely in outward shape, but also in all its characteristics, manners and habits. How easily therefore might it happen that such a tiger in miniature should likewise be possessed of a 'soul-recalling hair' and, by jumping on the water-bed, cause the dead body to turn into a dangerous vampire !

The contact of cats with a corpse is particularly unsafe on days which are styled 'tiger days', it being believed that, then, the influence of the feline race predominates more than on other occasions. To understand this, the reader must know that the Chinese divide time by using different cycles, each always starting afresh immediately after it has run off, and that one of these is composed of the names of twelve animals, arranged in the following unchanging sequence :

1 the Rat,

2 the $O x$,

3 the Tiger,

4 the Hare,

5 the Dragon,

6 the Serpent,
7 the Horse,

8 the Goat,

9 the Monkey, 10 the Cock, 11 the Dog, 12 the Pig.

Moving regularly in perpetual rotation, these twelve names are used to count years, months, days, and even hours, and each of these periods is believed to come under the special influence of the co-inciding animal, or class of animals. As the same holds good for the other cycles, which will be spoken of on the proper occasion p.45 (ch. VI), elements considered of great importance are offered for divination and soothsaying. 


\section{The religious system of China}

vol. I

Superstition with regard to the corpses of lepers.

Leprosy, the most loathsome disease known to the Chinese, regularly claims many victims in that part of the realm, the manners and customs of which we are more especially reviewing. Constantly living in a thousand fears of its attacks, which are regarded as incurable, or well nigh so, people at once abstain from preparing food in their houses on hearing that any body in the neighbourhood has fallen a victim to the malady, lest the contagion should sneak through the doors, windows and chimneys into the food and poison those who partake of it. Accordingly, they have to go elsewhere to take their meals. In the island of Amoy, we have seen whole hamlet repair for this purpose to the next village. We need not say that an end is as soon as possible put to this inconvenience by coffining the corpse and carrying it outside the inhabited quarter. Some people believe they can ward off the contagion by sticking a small green branch of the banian tree into the lintel of the doors of their houses.

Neutralizing the effect of thunder on a corpse.

Many Chinese say, thunder has the property of causing the bodies of the dead to swell. It has even been known to have puffed corpses up to such tremendous dimensions, that no coffins were big enough to contain them. Therefore, as soon as a peal of thunder is heard in the distance, the family hasten to place a heavy looking-glass of metal, the weight of a steelyard, or some other heavy object of small size on the breast or belly of the corpse, fully convinced that it will perfectly neutralize the bad effects of the storm. 


\section{The religious system of China \\ vol. I}

\section{CHAPTER III}

\section{Dressing the corpse}

\section{The grave clothes}

p.46 Unless a coffin and material for grave clothes are already in store at home with a view to a case of death, the last gasp of the moribund is a sign for the family to send some of its members out to purchase these indispensable articles. They also secure, if necessary, the assistance of a few elderly female neighbours or kinsmen in cutting out and sewing the last attire of the deceased.

The preparation of the grave clothes presents a singular mixture of solicitude and carelessness. Established custom lays great stress upon dressing the dead in brand new body clothes with some allowance, however, for one or two exceptional articles which the dead man was fond of wearing during his life, or which are still as good as new. On the other hand, the relatives are always anxious to wash the corpse without loss of time, and to dress it immediately after washing ; hence, in most cases, there is no time to prepare garments properly sewn. The women, indeed, often baste them in the roughest manner, nay, sometimes they simply paste the seams with starch or glue.

\section{The body clothes.}

The first garment that is put on the body is a pair of spacious drawers of ordinary bleached linen or cotton, lined throughout with a costly silken stuff of white colour called péh lîn, soft and glossy like velvet and commanding a high price in the market. This is to prevent the skin from being injured by contact with the clothes, and so to give comfort to the dead in his grave. People call this important article a tà-bah khò, 'breeches that cover the flesh'. A pair of 


\section{The religious system of China}

vol. I

stockings made quite similarly, called tà-bah béh, 'stockings that cover the flesh', are annexed, and the p.47 suit is completed by a corresponding tà-bah hiû or 'jacket which covers the flesh'. This garment reaches to the knees and looks like a large blouse with spacious sleeves, having a large flap on the breast, fastened at the shoulder and under the arm on the right side of the body. For both men and women the set is of the same material, cut and make. The expensiveness of the silk does not prevent the women from patching these clothes together in the careless manner we have mentioned, if they have to provide them after death has occurred.

Perhaps a few of our readers may be acquainted with the fact that marriages in China, both for the bride and the bridegroom, are connected with a rite of very ancient standing, which may be compared with assuming the toga virilis. It goes, in Amoy, by the term ch'iüng thâo, which seems to mean 'to raise the head', as it were in the world which now recognizes the couple as individuals of full virility. On an auspicious day selected with the greatest care by a member of the numerous class of so-called tik jit su, 'professors who select lucky days', or jít su, 'day-professors' - of whom we shall have to speak very often in this work, a suit of body clothes of white linen is cut out both for the bride and the bridegroom, and worn brand new during the said ceremonies and the succeeding day of the marriage proper, for, on this occasion, they themselves become brand new people. Now, after this, among the better classes, the young husband or wife will sometimes wash and lock up the whole suit, or part of it, never to wear it more except in the tomb. Such $c h^{\prime} i u^{n g}$ thâo $s a^{m}$-á-khò, 'jackets and trousers of the ch'iüng thâo rites', are then drawn immediately over the clothes 'that cover the flesh'.

Next comes an ordinary jacket of linen, cotton, or, in the case of wealthy families, of silk, with trousers of corresponding material, the latter, however, replaced in many cases by a pair of leggings or over-alls of the same material fastened by tapes to a band or sash which goes round the waist, and tied fast round the ankles. Over this jacket is placed a second and, eventually, even a third, in accordance with the devotion the family fancy they owe to the dead. Then follow one or more coats, robes, gowns or petticoats such as use to be worn by the living, varying, of course, with the p.48 sex of the dead, and, last, 


\section{The religious system of China \\ vol. I}

the outer garments, which occupy the whole attention of the family and therefore specially require ours.

The outer garments for male persons.

It may be said generally that, as a rule, a suit like the best which the dead man was accustomed to wear during his life, is made use of for his outer garments. Those amongst the lower classes who, though not rich enough to rejoice in the possession of ceremonial or official attire, yet are not entirely destitute of property, are generally laid in the grave in the very long and long-sleeved gown of blue colour, styled tńg sam or 'long cloak', which is the peculiar garment of the fashionable middle class. It overlaps to the right, buttoning at the side of the body. A kind of jacket reaching just below the loins and buttoning up the middle of the breast, comes over it. This is shortsleeved, that is, the sleeves just reach as far as the tips of the fingers. When wadded with cotton, such a bé koà or 'horse-mantle' is the usual overcoat of the better classes during the winter, but, when used as a grave garment, it is merely lined, as custom does not allow of wadded garments being placed upon the dead. The common skull cap of silk or horse-hair, called, on account of its shape, oán bō or 'bowl-cap', and a pair of ordinary shoes and stockings, complete this suit. People of lower standing, such as labourers and coolies, are dressed in the short blouse and trousers common to their class, and occasionally leggings are added thereto.

Family chiefs, living in very easy circumstances, for the greater part possess costly silken apparel for festive and solemn occasions, specially to be worn when offering sacrifices to their ancestors and gods. As it is a general idea prevailing all over China and traceable up to the highest antiquity that a dead man, on rejoining his predecessors in the next world, is there to continue his functions of serving and worshipping them, nay, to attend to those duties still more assiduously ${ }^{1}$, it becomes quite a matter of course that the said apparel is considered the proper dress to wear on appearing in the world beyond the grave. Consequently it is widely made use of as a grave

\footnotetext{
1 This subject will be treated fully in a subsequent Book, in a dissertation on the ideas relating to a future life.
} 


\section{The religious system of China}

vol. I

dress. A second and influential reason for this is, that, being present in the wardrobe of the dead, p. 49 the costume in question entirely relieves the family from making extra expenses for his outer garments.

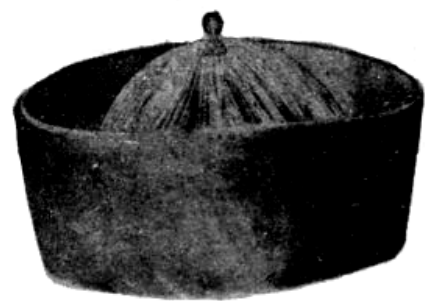

Winter Hat.

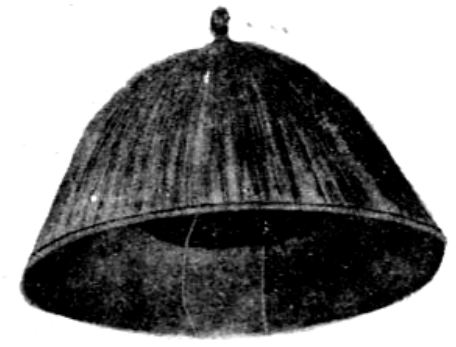

Summer Hat.

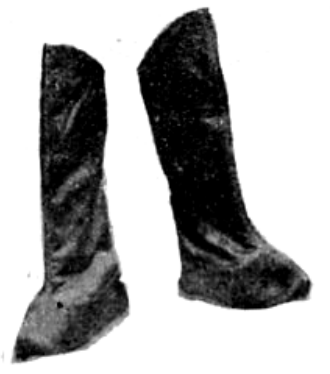

Boots.

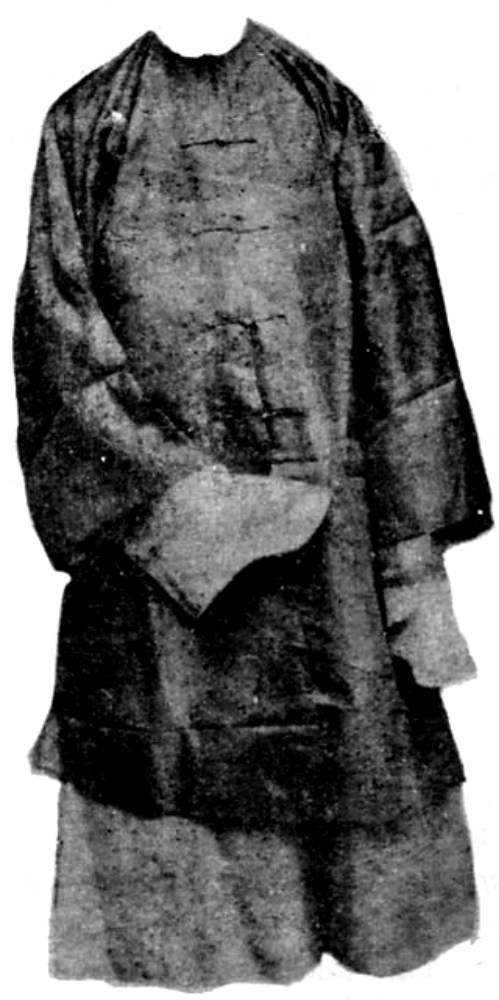

Inner and Outer Cloak.

PI. II. Sacrificial Attire for Family Chiefs

This dress which, in Amoy, goes by the name of thò p'aò, a term that may perhaps be translated by 'cloak-tunic', constitutes the true sacerdotal attire of the pater familias in his quality of high priest of the family. As such we shall 


\section{The religious system of China}

vol. I

have to mention it very often. Therefore we will here at once give such a description of it as will relieve us from all further details about it. But the reader should bear in mind that we describe it only in its Fuhkienese shape ; so, deviations of more or less importance may be found elsewhere in the empire, especially in the colder parts, where furs and other materials for clothing, as well as silk, are worn on an extensive scale.

The thò p'aò (see PI. II) consists of two parts, viz. a laī thò or 'inner cloak', and a goā thò or 'outer cloak'.

The inner cloak reaches nearly to the ankles. It has a large flap on the breast, fastened by one button to the right shoulder and with a few more under the right arm along the whole side of the body, just like the 'long cloak' described above ${ }^{1}$. The outer cloak is single-breasted, and buttons up the middle. It is shorter than the other one by about one foot, and the wide sleeves too are shorter, reaching only to the tips of the fingers. The ends of the sleeves of the inner tunic accordingly peep out, showing themselves in the horsehoof-shape for which Chinese official dresses in general are notorious. None of the cloaks has a collar. The material is, in most cases, the so-called thoân-lîng toān 'silk with coiled-up dragons' : a costly material in which circles, each with figures of dragons in them, are woven at regular distances from each other.

There is a special tho p'ao for winter, and another for the summer. In the first-named season, the two cloaks are lined with silk of a less costly sort. The inner cloak is then generally dark blue, and fastened at the waist by a sash or silken tape of about three centimetres in width, which goes three times round the body and has fringed ends hanging down from the knot at the back. In p.50 summer, the cloaks have no lining and are also of a lighter and more transparent material ; the inside robe is then generally white or yellowish, while the girdle, though of the same make and breadth as in winter, is wound around the waist only once and fastened at the back by means of a metal

\footnotetext{
1 Buttons in China mostly consist of a double cord made by rolling up a shred of the material of the garment; this double cord is sewed upon the edge, and ends in a knot or small metal globule that serves as a button. On the opposite edge of the garment a similar double cord ends in a loop serving for a button-hole.
} 


\section{The religious system of China}

vol. I

buckle, both the square parts of which are inlaid with a flat piece of coloured glass or precious stone. In both seasons, the outer cloak is mostly of a very deep blue colour, nearly verging on brown.

A pair of silk boots coming up to the knees and with very thick filt soles whitewashed all round the edge, are worn with the costume both in summer and winter. In the former season, the hat belonging to the dress is conical, and made of straw or fine bamboo splints covered with a yellow silk material. On the top of it there is a gilt globular button about the size of a dove's egg, around the bottom of which a fringe of red silken threads is attached, hanging down upon the hat and reaching as far as the brim. This brim bears, on one side, a single round pearl, real or false according to the means of the owner. A hoop of wickerwork or paste board, covered with cloth, is fastened inside the hat and serves to fix it on the cranium. In winter, this so-called joáh loéh or 'warm weather cap' is replaced by an ang iang bō or 'hat with red fringe', the shape of which may be best represented by supposing the summer hat to be rounded at the top, and its lower half turned up outwards till it comes on a level with the upper half. It also has a button and red fringes, but no pearl. The material is black velvet, and no bamboo or straw is used in its construction. Both hats are lined inside with red silk and fastened under the chin by strings.

Now bearing in mind that the winter suit alone is used to dress the dead, even in the hottest season of the year, the reader will have a pretty fair idea of the raiment in which nearly all Chinamen of any standing appear in the World of Shades. It still remains to be said that nearly every man who can afford the expense permits himself the fashionable luxury of buying an official degree, and becomes thereby entitled to wear, both in this world and the next, on the breast and back of the outer cloak a square piece of silk embroidered with the insignia of his rank in the shape of a bird or quadruped. Never does the family neglect to adorn the dead p.51 with these badges, everybody being firmly convinced that they will give him also beyond the grave the mark of a man of distinction and consequently ensure him proper treatment on the part of the ghosts and spirits abiding there. 


\section{The religious system of China \\ vol. I}

In the event of the family knowing that the costume has ever during his life been lent out by the owner to a friend or acquaintance not belonging to his own clan, they never permit his body to be dressed in it, but purchase material for a new attire of the same sort and, if time fails them to sew it properly, cut and baste it in the careless way described. They are compelled to act in this manner on account of a prevailing social rule which forbids their contributing in any way to other people's ancestral sacrifices. As has been intimated already on page 27 , everything a child possesses belongs to his parents, even though they are dead; hence, offerings presented to a strange soul are regarded as a theft from the holy ones, who may, however, themselves set apart in the other world for such souls, if they like. It is not even allowed to contribute to other people's sacrifice by lending them a sacerdotal dress, and if the man who has committed such an unfilial act should venture to appear in that very dress before his ancestors, he would certainly run the risk of his crime being discovered, and be severely punished.

Dispatching the dead to the next world in sacrificial robes was generally practised already during the Cheu dynasty. The reader may convince himself of this by perusing, in chapter $V$ of the second part of this Book, the description of the way in which official persons were dressed in those ancient times. Beyond all doubt we have here a second reason why people are still so partial now-a-days to being buried in the thò p'aò attire : indeed, a tendency to blindly imitate the rites and ceremonies of holy antiquity has always been one of the most striking characteristics of the Chinese race.

Mandarins, and graduates actually promoted by competition at the literary examinations of the State, are dressed in the full uniform appropriate to their rank, including all the official insignia and ornaments. It is, however, by no means necessary to procure a brand new set of these garments. Official robes, as well as the sacrificial dress just described, are, in fact, always made of such exquisite silk and, relatively speaking, so seldom worn, that the best suit the dead man possesses is always quite good enough to be worn in the grave.

It still remains to be mentioned that great numbers of male p.52 persons dying in ripe, old age are dressed in an outer attire professedly borrowed 


\section{The religious system of China}

vol. I

from very high antiquity, and therefore worthy of special attention : It consists of a long cloak of deep blue brownish silk. Around the neck and on

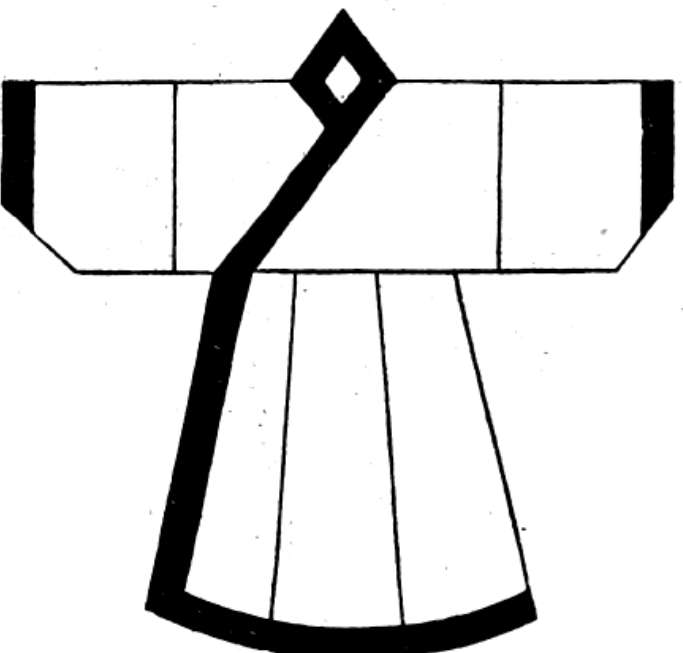

Fig. 1. 'Deep Garment' of Antiquity.

called ch'im i or 'deep garment'. It is frequently mentioned under this name in the ancient books of rites, which shows that it must have been one of the principal articles in the wardrobe of the ruling classes during the Cheu dynasty. Commentators say, it bore this name because, when worn, it deeply concealed the body. A picture of the dress, as it is supposed to have looked in those ancient times, is given in ch. 79 of the Khienlung edition of the $\mathrm{Li} \mathrm{ki}$; fig. 1 is a copy of that picture on a smaller scale.

p.53 As a grave garment it is now-a-days always accompanied by a lined cowl of corresponding material, covering the whole head except the face, and hanging down halfway over the back (see fig. 2). This so-called hok kun, 'kerchief of one full width of cloth', is likewise borrowed from the Cheu dynasty, being mentioned by the I li amongst the grave clothes then in vogue with ordinary officials. The reader will come across it as such in ch. $V$ of the second part of this Book.

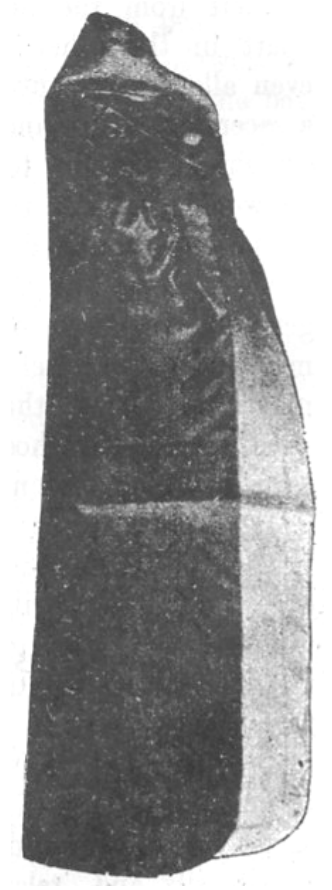

Fig. 2. Cowl called Hok kun. 


\section{The religious system of China}

vol. I

Grave clothes for women.

Women are generally laid in the tomb in the best attire to be found in their wardrobe. Those belonging to the better classes accordingly appear in
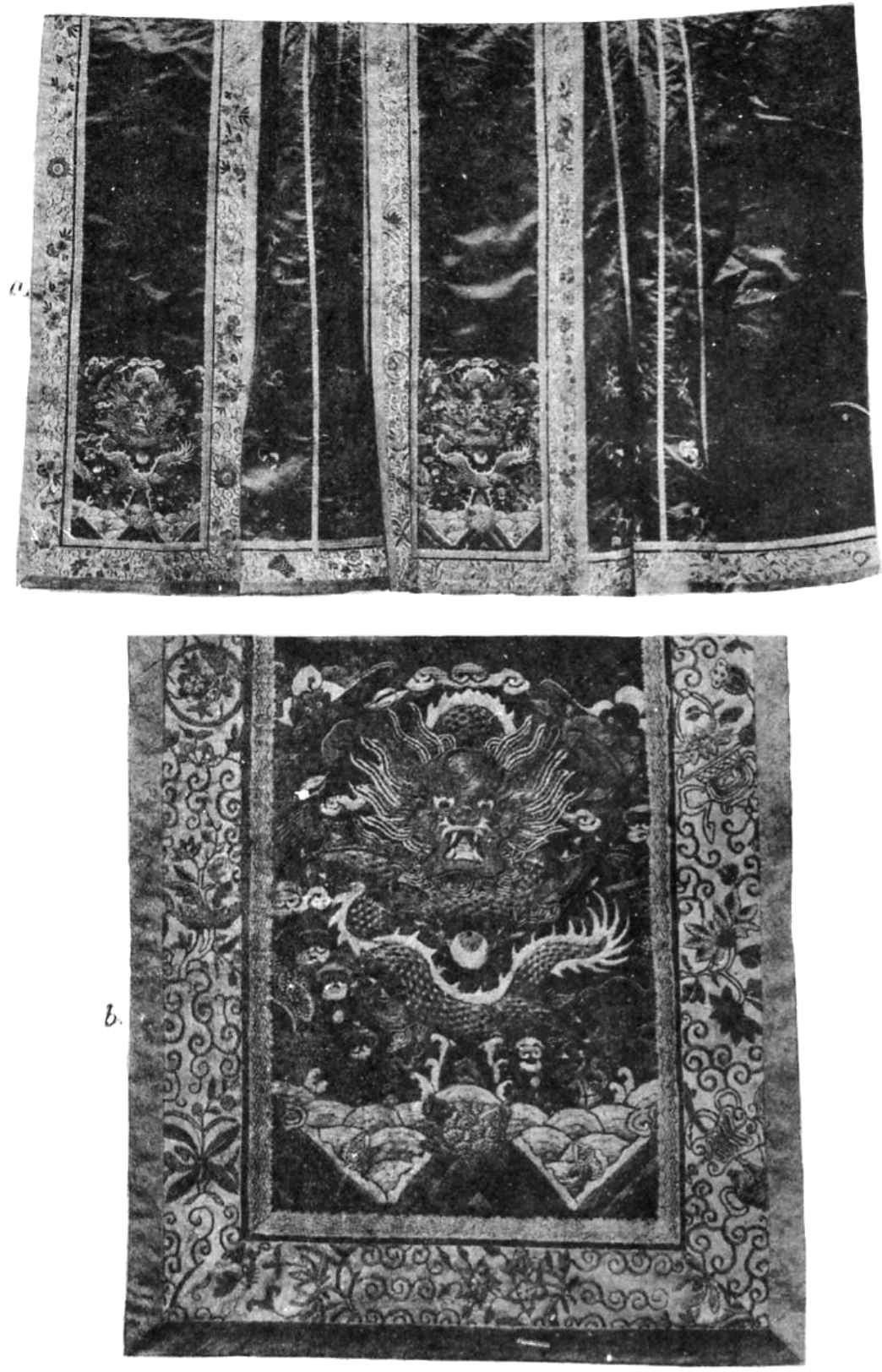

PI. I I I. a. Petticoat of a Bride. - b. The Principal embroidered figure on a larger scale.

the other world in beautiful embroidered robes. Many of the wealthiest, especially if their husbands bear an official title of significance or are actual servants of the state, are attired in a rich dress which is at the same time both the official uniform of mandarins' wives and the common bridal costume 


\section{The religious system of China}

vol. I

of all classes of the people who can afford to buy or borrow it. It consists of : 1. A bóng kûn or 'dragon-petticoat' of green silk (see PI. III), so called because it is embroidered both before and behind with a dragon rising out of the waves and flying landward, to descend on fields and meadows in the shape of fertilizing rains : in fact, the dragon has been in China, since time immemorial, the principal divinity of rains and waters. Each dragon is surrounded by embroidered figures representing clouds, and further by a stag, a tortoise, and a crane : the symbols of old age, joy, pecuniary profits and happiness, the reasons for which will be explained presently (p. 56 seq.). A bat is also embroidered on the left and right of each monster, because the bat is an emblem of happiness from the similarity in the sound of its name and the word felicity, which are both pronounced fuh ; moreover, the same element [] or 'fulness' occurs in the written form of each of these two words.

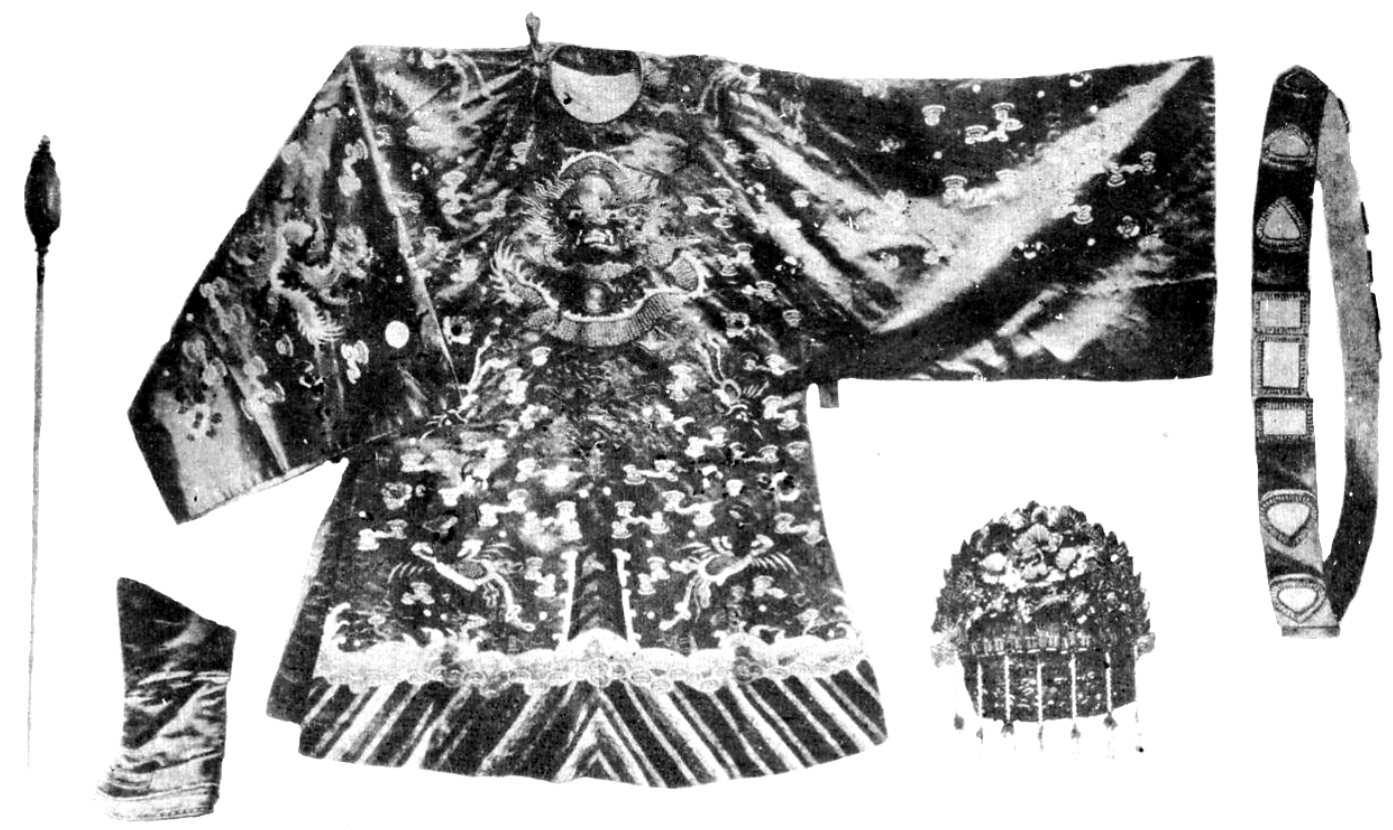

PI. I V. Mantle of a Bride, with Hair-pin, Boot, Hood and Girdle.

2. A bóng ó or 'dragon-mantle' (see PI. IV). This garment, made of a very bright red silk, has a large lapel on the breast, which is fastened on the right side of the body. On the breast and on the back there is large dragon likewise rising out of the water and moving landward, and, besides, there is a smaller dragon on each of the very wide sleeves. Each monster is trying to swallow the sun, and is surrounded by clouds and bats. The mantle is further 


\section{The religious system of China}

vol. I

ornamented on both p.54 sides with fishes, flowers and stars, as also with phenixes, which are in China the favourite symbols of matrimonial felicity.

3. A hê poè or 'clouds-mantilla' of black silk (PI. V). It has no sleeves at all, and fastens on the middle of the breast. On both the breast and the back

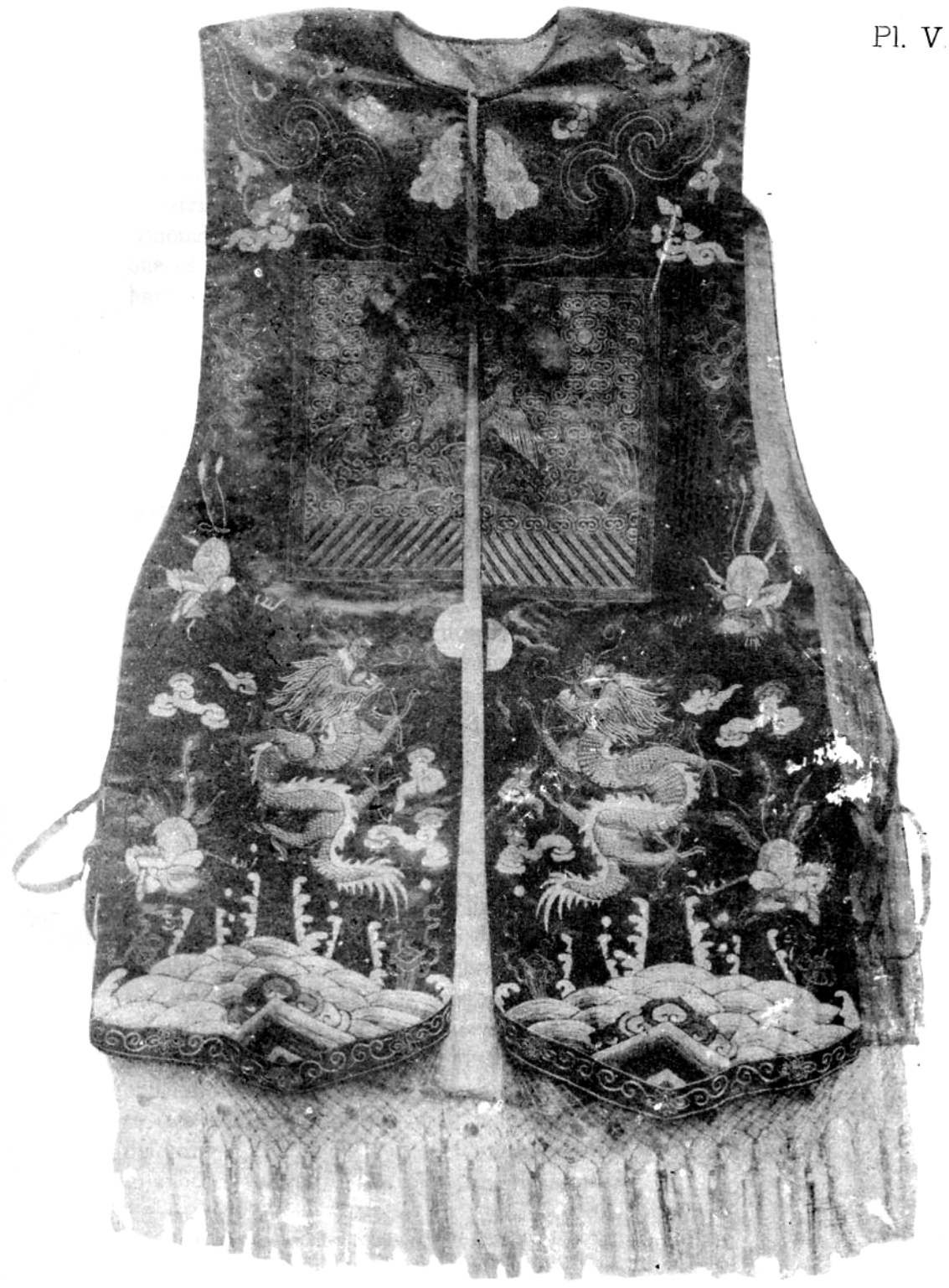

PI. V. Mantilla of a Bride.

is stitched a large square piece of silk embroidered with the bird or quadruped emblematic of the official rank, and underneath each square are a couple of dragons facing each other and trying to devour a sun that stands betwixt them. The monsters are likewise represented as rising out of the waves, and 


\section{The religious system of China \\ vol. I}

surrounded by clouds, bats and phenixes, while the dress is studded on the shoulders and about the neck with ornamental flowers. Both before and behind there is a deep silk fringe of variegated colours, hanging down from a sort of silken netting.

The figures on each of there costly garments are all embroidered, the dragons mostly with gold thread of a light and dark yellow tastefully intermixed, the others with silk of various colours. A so-called kak toà or 'horn-belt' of bamboo, covered with red silk and ornamented with small square frames each holding a piece of either false or real jade stone, is suspended from the red mantle, and encircles the waist without fitting close round it. To this costume belongs also a pair of small boots of red silk fitting tightly round the lady's crimped feet and reaching nearly as high as the calf of the leg. And the head is covered with a bride's hood called hōng koan or 'phenix-cap', represented with the girdle and a boot on PI. IV. This curious head-gear may be described as a quarter of a globe of thin twined wire, entirely covered on the outside by numerous leaves, butterflies, flowers and so on, all made of thin, gilt copper plate. Four leaves, standing out conspicuously above the rest, bear respectively the characters [], [], [] and [], which make the sentence : "I have received an official appointment from Heaven", i. e. from the emperor, or Heaven's Son. A broad band of red silk tied round the head is worn with this hood. Copper figures of the eight principal beings who have attained to immortality, or the so-called pah Sien, are affixed to that band, and a silver hair-pin with a head of precious stone goes through the coiffure, such an instrument having been considered from the highest antiquity as an indispensable object for consummating a girl's marriage.

It is almost needless to say, that in the case of a woman great care is also bestowed upon her coiffure and body ornaments. p.55 Hair-pins of silver and even of gold, and artificial flowers are lavishly used; moreover, rings of precious jade and metal are put around the wrists and ankles, the poorer people always preferring counterfeit articles to none at all. Amongst the hairpins there is almost always one of very peculiar shape and meaning. We have depicted it in Fig. 3. It is a miniature copy of a crosier which Buddhist clergymen wield and brandish while celebrating certain religious rites, 


\section{The religious system of China \\ vol. I}

especially those which are designed for delivering souls from hell ${ }^{1}$; as such, it not only exert a great power over infernal beings, but, in general, resists

Fig. 3. Hair-pin resembling a Crosier.

and counteracts the whole host of spirits of darkness that, according to Chinese conception, are always at hand to injure men and souls, especially the latter who, owing to the frailness of their disembodied state, are not endowed with much defensive power. As the said crosier bears the name of sik thng, the pins are called sik thng tsiem, 'sik thng hairpins'. Elderly women are also very fond of wearing one of these pins in their hair during life.

To increase the useful effect of such a hair-pin, small silver figures representing a stag, a tortoise, a peach and a crane are fastened to its head by means of little rings. The stag is the generally acknowledged emblem of old age, joy, and pecuniary profits; the tortoise and the peach of longevity and immortality, the crane of long life and happiness. It would carry us too far from our subject to explain the reasons for all this in detail, and so we content ourselves with a few notes, deferring a thorough treatment of the subject to another volume. As to the stag, the famous p.56 philosopher Liu Hiang, who lived in the first century before our era, stated in his 'Traditions on the Files of Immortals', Lieh sien ch'wen that the animal turns blue after a thousand years; and Koh Hung, the renowned Taoist author who lived in the fourth century after Christ, relates in his work known as Pao P'oh tszē or 'The Philosopher Pao

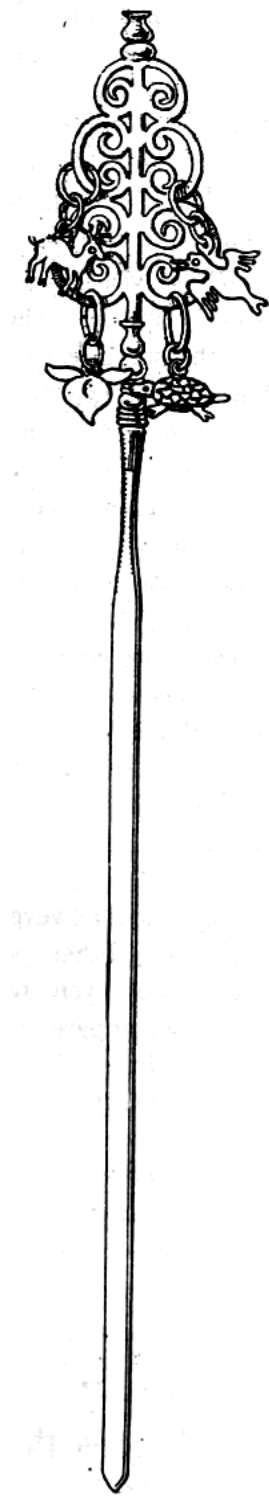
P'oh', that it is able to live a thousand years, and turns white after five hundred. The stag is, moreover, a symbol of both joy and prosperity because its name luh is pronounced like the character [], which means 'delight', and like the symbol [], 'a large income derived from an official position'. And as to

\footnotetext{
1 More particulars about the religious instrument will be given in another volume, dealing with Buddhism.
} 


\section{The religious system of China}

vol. I

the tortoise : - the Chinese people, observing that this animal does indeed attain a remarkably long age, have always been fond of dilating on its longevity, and divers marvellous tales have been narrated with regard to it. The famous Liu Ngan, who lived in the second century before our era, even pretended in his 'Explications of the Great Light', Hung lieh kiai, that it could live three thousand years.

We now come to the peach as a symbol of longevity. The Han Wu-ti nei ch'wen, 'Traditions concerning the emperor Wu of the Han dynasty' who reigned B. C. 140-86, says that Si Wang Mu or 'the Royal Mother of the West', ever famous in Chinese mythology as the queen of the immortal beings in the Kwunlun mountains, possessed a peach tree which bore fruit only once in three thousand years. A few of these peaches she presented to the emperor, telling him, however, they could not be grown in this our ordinary world. On other occasions she is found in the books to bestow peaches of even ten thousand years old upon her votaries and favorites: compare, e. g. the Shih i ki or 'Record of forgotten Matters', a work from the hand of Wang Kia, dating probably from the fourth century. Lastly, the 'Canon of curious Things connected with Spirits', Shen i king, a work of the fourth or fifth century, tells in its chapter on the 'Eastern Deserts' of a peach tree in the east, five hundred feet high, having leaves of eight and fruits of over three feet, from the stones of which the elixir of life could be decocted.

p.57 Finally, the crane or stork is a symbol of longevity because, « when a thousand years old, it turns blue, and when twice that age, it grows black». This doctrine may be found preached in the 'Commentaries on the Past and the Present', Ku kin chu, a work of the fourth century (ch. 2). Liu Ngan also says in the 'Explications of the Great Light' (ch. 17) that the «crane lives a thousand years ». Its position as the bird of auspicious influence it mainly owes to the circumstance that its name hok or hoh [] in many languages of the empire is a synonym, or well nigh so, of the word 'happiness, prosperity', which is written [].

Returning now for one moment to the hair-pins, we wish to state, that their good qualities are considerably increased by having them made in a year which has an intercalary month. It is, in fact, easy to be understood that, 


\section{The religious system of China}

vol. I

whereas such a year has one month more than an ordinary year, the lifeprolonging power of a pin made in the course of it must necessarily surpass by one twelfth that of others. People are also careful to introduce in each subsequent year of thirteen months a little ring between the pin and each of the figures suspended from its head, so that after a long period they all hang down by little chains.

Finger-rings too are oftentimes lavishly made use of for fitting out a corpse, in the case of males as well as females. In many cases the family use a set of thirteen, all made, for a similar reason to that prescribed for the hairpin, in a year of thirteen months. If the dead man has not procured them for himself in his old age with a view to his approaching end, or has not received them as a present from his children, the survivors purchase them at once in a silversmith's shop, where many sets are always kept ready at hand for customers who may want them for their dead.

Before continuing our description of the grave clothes, we must acquaint our readers with an important conceit of the Chinese which sheds much light upon some practices that have been under our notice and those still to be described afterwards : - things of good omen will, when placed in a tomb, cause the benefits they express or symbolize to become real blessing to the offspring of the deceased. This idea is most intimately connected with the belief that souls continue to dwell with the body in the grave and from thence distribute benedictions and blessings over the offspring ; p.58 like a red thread it runs through all the practices connected with the tomb and will as such come chiefly to the front in the third part of this Book, more especially in the $12^{\text {th }}$ chapter. Now the reader will understand that it is by no means merely a desire to ensure a happy fate to the dead which prompts children to place a hair-pin like that described on the deceased : the hope that it may serve with all its appendices like seeds sown, and ripen into real happiness and old age for the offspring, plays by far the greatest part in it. This also explains why the Chinese are so partial to dressing their deceased mothers in bridal attire : - this being in reality the uniform dress of mandarins' wives and, moreover, covered all over with symbols of felicity, wealth, joy and longevity, it with undoubtedly endow each woman, who wears it in the tomb, with the faculty of procreating happy, wealthy and longlived descendants holding high 


\section{The religious system of China}

vol. I

functions in the empire - the greatest bliss and honour imaginable for every true son of China. That we are here face to face with the reason why this dress has become the peculiar attire to be worn at marriage $i$. e. at the moment when the procreation of children is set agoing, we need not say. It is now clear why every Chinese thinks it so highly important to dress his dead in the best clothes he can afford: to himself and his offspring is thereby ensured such a social standing and amount of prosperity as will entitle and enable them to wear dresses of corresponding quality and value.

Grave clothes for children and youths.

About the grave clothes for babies and young children there is but very little to say. One general rule holds good for them : they are the best child-

Fig. 4. Boy's Tunic of Antiquity.

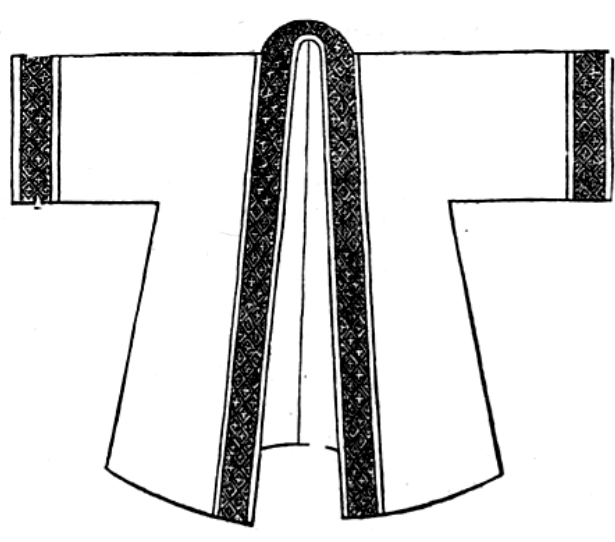

garments the parents have at their disposal in the house. For children under the age of maturity but over, say, ten years, well to do people procure oftentimes a special gown of blue unflowered silk, called sing sam or 'young man's garment', which overlaps to the right. It is an imitation of a dress which, on account of some hazy references

made to it in the Classics, is generally believed to have been worn by young boys during the Cheu dynasty, and of which Fig. 4 is a representation, copied

Fig. 5. Youth's Hat.

on a smaller scale from a figure given in the Khienlung edition of the Li ki (ch. 79). A hat of stiff paper covered with silk or p.59 velvet, in many cases, embroidered with flowers and other figures in gold thread, is worn with that gown. It

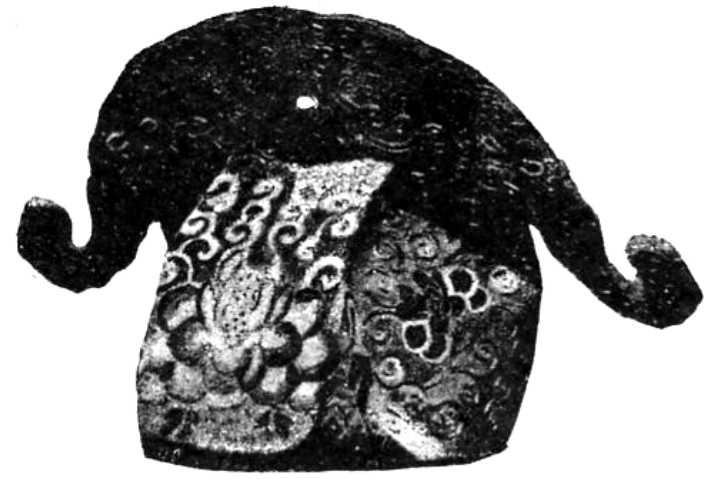
has either two curling points on the right and left reminding one of buffalo 


\section{The religious system of China \\ vol. I}

horns (Fig. 5), or a cover which resembles the roof of a house (Fig. 6); in the former case, people call it a sing bō or 'youth's hat', in the latter a ts'ù hiā bō

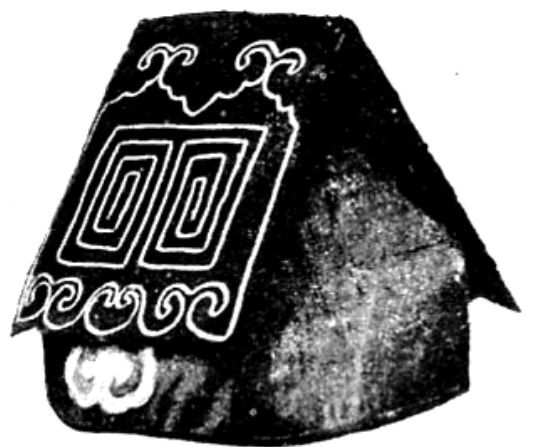
or 'roof-hat'. It always has two blue pointed ribbons behind, hanging loosely down the back of the wearer.

Fig. 6. Roof-hat.

This costume, the people pretend, is a legacy of former dynasties, when, they say, it was the usual dress for boys of fashionable families. Now-a-days it is no more worn, except on the stage in historical plays, and by young children on special festive occasions, such as New Year's day. That it still plays such an important part as a grave dress is a good illustration p.60 of the tenacity of customs as soon as they become connected with observances of a religious character.

\section{Grave clothes prepared during life.}

At the outset of this chapter we directed the attention of the reader to the fact that, in China, grave clothes are also procured during the life of the person for whom they are intended. In such cases they are never, like those prepared after death, carelessly basted or pasted together, but, on the contrary, are made as well and strong as the garments the living are accustomed to wear, there being plenty of time to finish them properly.

Procuring grave clothes during life is especially in vogue with people who have reached a certain age, say 50 or 60 , and at the same time possess means which allow them to make the necessary outlay. Some people procure a complete set, most persons, however, only a suit of tà bah clothes with the outer garments. Any outfit kept ready for the journey into the world to come goes in Amoy by the term tiung laō sam, 'clothing laid out for the old age'. Indeed, the Chinese generally avoid plainly speaking of death and things connected with it by their proper names, and prefer to replace these by wellsounding terms indicative of good luck; for in this way, they say, much of the influence of death is neutralised, nay even turned into good. Old age being a benefit the Chinese prefer above all things, most people have the clothes in question cut out and sewn by an unmarried girl or a very young woman, 


\section{The religious system of China}

vol. I

wisely calculating that, whereas such a person is likely to live still a great number of years, a part of her capacity to live still long must surely pass into the clothes, and thus put off for many years the moment when they shall be required for use.

Amongst all the tiung lao clothes none is so interesting as the so-called $s i \bar{u} i$, 'garment for a long life'. It is a long gown of very precious silk of the deepest blue colour slightly passing into a reddish brown; the lining, likewise of silk, is of a very bright blue. It is generally shaped like the ancient 'deep garment', described on page 52 ; in many cases, however, it has no lapel, but buttons up the middle of the breast. When cut like the 'deep garment' (see PI. VI), the broad hems p.61 peculiar to this garb are of costly bright blue silk. In the other case (see Frontispiece), there is only such a hem round the neck, not reaching further down than the heart; it is then very often of a white colour and embroidered with peony-flowers, phenixes, and divers other ornamental figures.

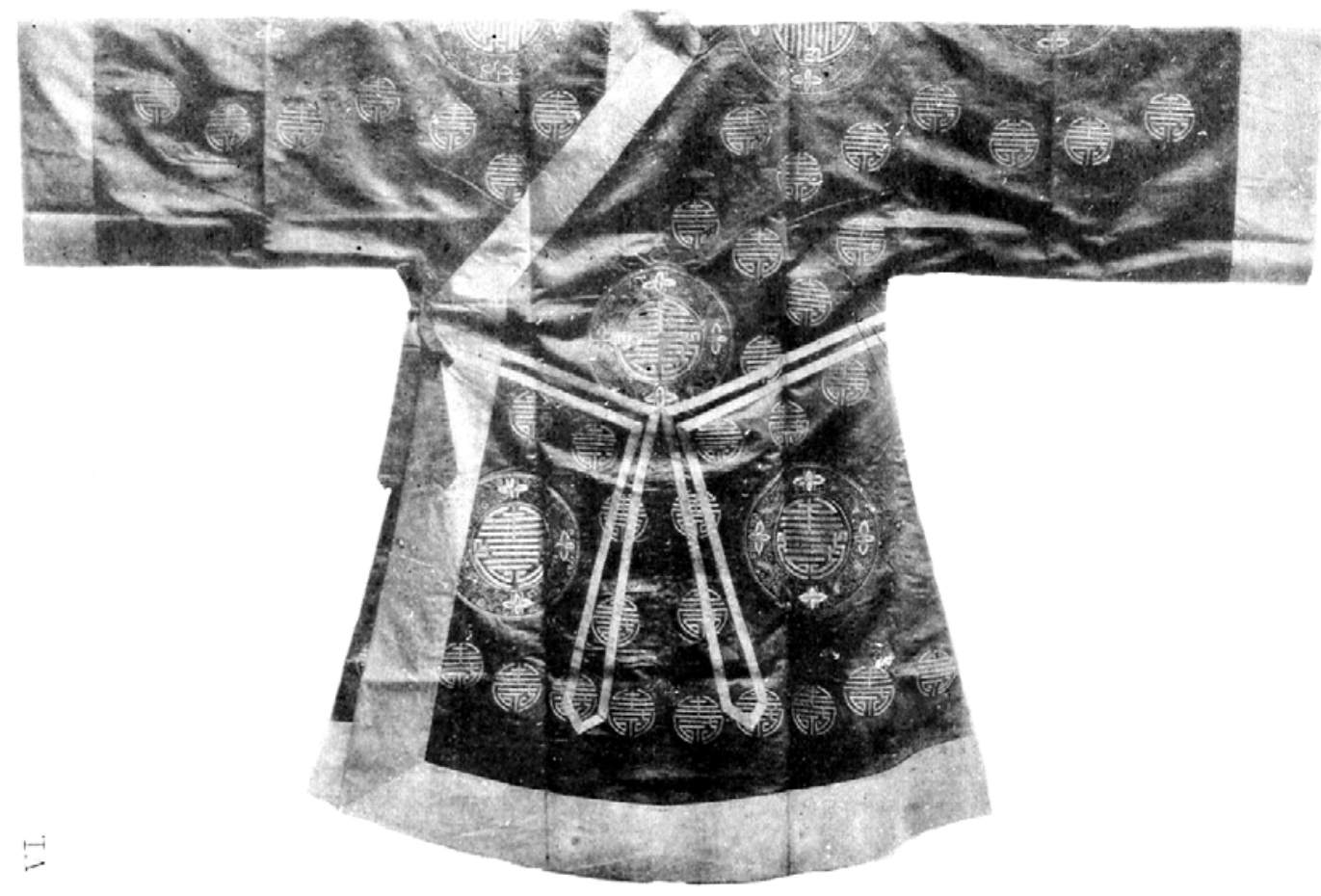

PI. VI. Longevity Garment.

The 'longevity garment' owes its name chiefly to the fact that it is embroidered all over with characters in gold thread representing the word longevity, pronounced siū in the language of the Amoy people. Each is circular 


\section{The religious system of China}

vol. I

in shape and, besides, in the phantastic form known as the seal-character ; sometimes such rein is given to fancy and ornamental taste that the figure is by no means recognizable. On the middle of the breast and on the back, and a little lower down on the right and the left side, as well as on each of the shoulders, and on the sleeves at the elbows, there is such a character of larger dimensions, encircled by a wreath of flowers, leaves, phenixes, cranes etc., all embroidered in variegated silk. For the rest, the garment is studded with siū characters of smaller size and without a wreath ; in many cases, each of these has a shape different from the other, for the Chinese are in general very fond of writing the character, when used for ornamental purposes, in as many ways as their fancy can possibly invent. It is on account of these numerous siū figures that the garment is also often called pik siū $i$, 'garment of one hundred siū characters'.

That this costly garment is only found amongst the well to do, need not to be said. It purports in the first place to prolong the life of the owner, who therefore frequently wears it, especially on festive occasions, in order to allow the influences of longevity, created by the many characters wherewith it is decorated, to work their full effect upon his person. On the anniversaries of his birth he will scarcely ever neglect doing so, it being generally acknowledged amongst the Chinese that it is extremely useful and necessary then to absorb a good amount of vital energy, in order to remain hale and healthy during the ensuing year. Friends and kinsmen who throng the house to take part in the festivities, will then as a rule greatly admire the dress and tender their reiterated congratulations to the happy wearer, whose children have been so filial and so blessed by ${ }_{\text {p. } 62}$ fate as to have bestowed a present of such delicate and precious description.

Indeed, a longevity garment is nearly always the gift of dutiful children to an aged father or mother, an expression of their intense desire that the old man or woman may continue to live with them for many and many years. It is but seldom procured by the person who is to wear it in the grave. When the children have determined upon presenting it to one of the authors of their life, they make it an object of extreme solicitude. In not a few cases they will order the material from Shanghai, Suchow, Canton, or some other large city famous for its silk, and secure first-rate tailors to make it on a lucky day, 


\section{The religious system of China \\ vol. I}

carefully selected for the purpose by a 'day-professor' (p. 47). And when it is finished, the first birthday of the senior, or some other auspicious day preceding it as near as possible, is chosen for the presentation. A few plates of eatables and dainties, flanked by a couple of lighted candles, having been placed on a table in front of the domestic altar as a sacrifice to the ancestors and tutelar divinities residing there, the donors, attired, if they possess it, in the sacrificial raiment described on page 49 seq., or, otherwise, in the best suit they have, solemnly make their appearance, sacrifice some incense-sticks and thank by the mouth of the eldest the invisible protectors of the house for having already granted such a respectable old age to the beloved one as to render the possession of a longevity garment desirable. They further entreat them to continue their protection in the same way for many, many years to come, and the whole company thereupon turn to the senior, kneeling down to worship him by knocking their heads three times against the floor. The eldest one then hands him the dress with or without more grave clothes besides. The old man has, of course, scarcely words enough to express his gratitude for the filial sentiments displayed towards him, and in a few moments walks proudly up and down the hall, accoutred in this new acquisition to his wardrobe, gladly receiving the congratulations of the friends and kinsmen who take part in the festivities of the day. The sacrifice on the domestic altar is specially bounteous when the anniversary represents a multiple of ten, because, in the case of an elderly person, his children and grandchildren consider themselves then in duty bound to make the day an occasion of very great rejoicing and festivity.

Owing to the fact alluded to on page 48 that male persons have a great predilection for being interred in the sacrificial robes p.63 tho phaò, the longevity garment is, comparatively speaking, much oftener presented to old women than to old men. For both sexes it is of exactly the same description. A woman will, as a rule, wear with it the 'dragon-petticoat' described on page 53 ; a man a pair of silk boots and, besides, the cowl called hok kun (see p. 52), because the garment of longevity represents, as we saw, the 'deep garment' of antiquity, to which such a cowl belongs as an inseparable appendix. 


\section{The religious system of China}

vol. I

Besides prolonging the life of the owner, the longevity garment purports to insure a long life to his descendants as well. The reason may be deduced by the reader himself from the general rule already given on page 57 , that the Chinese firmly believe that objects placed in a tomb are capable of causing the good things which they express by their shape or name, to fall as a real blessing on the offspring of the person buried in that tomb.

Like the hair-pin described on page 55, and for reasons quite similar, grave clothes prepared during life are made by preference in a year which has an intercalary month. The very best imaginable, however, are those made in that month itself. It is scarcely necessary to add that people will also soon determine upon making the grave clothes when a kinsman is seriously ill, especially when they have but little hope for his recovery.

When a family has resolved upon presenting a set of grave clothes to an aged or sick parent, the sons-in-law are strictly bound by customary law also to contribute a part. As a rule, their wives will prepare a long gown of unflowered silk to be placed immediately below the upper garments, and therefore called ji tîng sam, 'gown of the second layer'. Indeed, owing to the fact that in consequence of their marriage those wives have had to adopt the parents of their husbands as their own, they have to mourn for their own parents only in the second degree 1 ; consequently, by procuring the second layer, they fully acquit themselves of their duty and may freely leave the care for the outside or principal garments to the mourners of the first degree, to wit their brothers and sisters at home, who never have been withdrawn from the dead man's unlimited authority. For a mother, the ji tîng sam is generally red, for a father, dark blue. If death comes suddenly, and such a gown has not been prepared in advance, the married p.64 daughters are, if the time is too short to make one properly, bound at any rate to send money to the house of death for the inmates to buy the necessary material and have the gown in question made together with the other grave clothes.

The material way in which the Chinese prepare for making their appearance in the next world is, like most of their funeral customs, rendered sacred by precedents set by the venerated forefathers of the nation. Speaking 


\section{The religious system of China \\ vol. I}

of the three most ancient dynasties of the empire, the $L i k i$ states in its $19^{\text {th }}$ chapter (leaf 8) :

« After sixty, they are put in order every year ; after seventy, once in every season ; after eighty, once a month ; and after ninety, they are kept in good repair every day. Only the swaddling-bands, the sheet which is to be wound around the corpse, the palls, and the sack enveloping the body, are put in order after death (130).

\section{Superstitious customs connected with grave clothes.}

We may not allow ourselves to leave the subject of grave clothes without having noted some curious instances of popular superstition connected with it. In the first place it is worthy of notice that, when made at home, grave clothes are nearly always exclusively provided with buttons of woven material, such as are described in the foot-note on page 49 : scarcely ever is the knot of those buttons replaced by a copper globule, as is the case on a most extensive scale in upper garments for the living. Metal buttons will, as people say, give trouble to the dead by injuring his body while it is decaying in the grave, and consequently cause great injuries also to his posterity; they may even cause the latter to be visited by diseases of all kind and numerous cases of untimely death. Many people, however, consider the matter of but secondary importance, and do not at all object to having a few such buttons on the upper garments; but never would any woman allow her dead to be buried with too many of these dangerous things on the body.

The number of suits is another point of great solicitude. Five layers of dressing, each lined garment being counted either double or single, are once for all proscribed, because the word five, $g \underline{\bar{a}}$ p.65 or wu, is a homonym of another, written [] and meaning 'involuntarily to bring disaster and evil upon

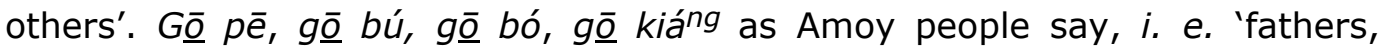
mothers, wives and children, all visited by misfortunes', this is the fate which no dead person can help bringing upon his offspring for many generations to come, if they have buried him in five dresses, or five layers of dressing. It is, in consequence, a happy coincidence that the customary minimum of dresses,

${ }^{1}$ Compare the third part of this Book, ch. VI. 


\section{The religious system of China \\ vol. I}

below which no decent family which respects itself dares by any means go, viz. a 'jacket that covers the flesh', a couple of ordinary jackets, a 'long habit', a 'horse-mantle', and the two gowns of the sacrificial attire make up a number exceeding five.

Well-to-do people nearly always carry the number up to nine at least, counting the lined garments each as one layer. Many, however, would feel ashamed to put on less than eleven, thirteen, or even more dresses. Owing to the fact that Chinese philosophy has always identified even numbers with the Yin part of nature, that is to say, with cold, darkness, evil, feminality and such sort of things (comp. p. 22), while the odd numbers represent the opposite good elements, an even number of grave clothes is always most decidedly avoided. Wrapping up a dead person in Yin ciphers would, indeed, wilfully tend to destroy his luck in the grave and the next world : and his unhappy condition would, in its turn, have a baneful effect upon his offspring. Not to mention serious consequences of other descriptions, the deed would, in the first place, cause the dead to be re-born at a future time in this world as a woman and this woman to bring forth scarcely any but female children; and none of these fatal chances in the lottery of existence is desired by any true son of the Empire of the Midst, where woman holds place as a being of very inferior order, and daughters count for nothing in a family.

The quantity of grave clothes is dependent also to a great extent upon the age of the deceased, increasing with his years. The prevailing idea that filial duty requires a dead man to be dressed in numerous suits induces many a poor family in Amoy to use grave garments of material so cheap, that they would, if worn by a living person, hang about his body a hopeless mass of shreds and tatters in a few hours. But why should not miserable imitations p.66 of costly silk become the most ornate clothes in the next world, if even tinned piper sheets pass there for sterling currency of the highest value ?

Dressing the dead in numerous suits obtained as an established custom already during the dynasty of Cheu. This is clearly proved by the $I l i$, whose elaborate account of the way in which deceased officers were then dressed for the grave is reproduced at full in the second part of this Book (ch. V, $\S 1$ ) and may be consulted there. 


\section{The religious system of China}

vol. I

Leather may form no part in grave clothes, under any pretext whatever. In the event of boots or shoes having been purchased for the use of a dead person, the family are always careful to tear off the thin layer of leather, which is usually stitched underneath the soles. It is evident that Buddhist influence is here at work. Many tenets of this Church have obtained a strong hold upon the people, and numerous men and women partly or totally abstain from animal food, in obedience to the rescript not to kill, nay, to avoid everything that might lead to the slaughtering of animals : using no leather may be classed on a level with such abstinence. But there are other reasons. The prevailing ideas concerning a future life being greatly influenced by doctrines derived from Buddhism, everybody knows Yama, the king of Hades, and, because pictures of his dreadful tribunal are regularly distributed over China in large quantities, all Chinese are acquainted also with his two inseparable attendants, 'Father Buffalo' gû iâ, and 'Father Horse' bé iâ, each represented with the head of the animal of which he bears the name. These beings, when ordered by their master to inflict punishment upon a soul, will undoubtedly rage with redoubled fury against it, if they perceive it wearing the tanned hide of their congeners under its feet. It may be useful to observe, that we are here face to face with a custom of respectable antiquity, as it is written in the Yiu-yang tsah tsu ${ }^{1}$, an interesting work of the eighth century (ch. 13) : «When seeing off a deceased person, it is not permitted to present articles of leather to him ».

\section{Dressing the Dead.}

p.67 Having finished out lengthy description of the grave clothes, we have now to describe the way in which they are arranged on the corpse.

Under the eaves of the hall the mourners place on the floor a large shallow tray of wicker work : an important article of daily use in every family, serving to winnow rice and separate this from the chaff by shaking it in the

\footnotetext{
${ }^{1}$ Author : Twan Ch'ing-shih.
} 


\section{The religious system of China \\ vol. I}

wind. On this tray is placed a wooden form or chair, which is thereupon mounted by the principal mourner. He is stripped of his clothes as far as decency will allow, and is covered with a large round hat of bamboo, such as is commonly worn by all the lower classes to protect them against the sun and rain. Assisted by his mother or wife, he now puts on the 'jacket which covers the flesh', passing at the same time a long hempen rope through the sleeves and over his back; and subsequently all the shirts, coats, robes and gowns destined for the dead are one by one arranged on his body in the required sequence. During this proceeding he holds in his hand a bamboo pole, to the top of which a leafy branch of the banian tree is affixed, in order that the bad influences of the surrounding atmosphere, which might otherwise sneak into the garments and so afterwards injure the dead, may be kept at a respectable distance. In many cases, however, the branch is attached to the top of the hat, or replaced there by a flower, which people feel sure will have the same good effect.

The clothes having been fastened to one another at the back and in front by means of a couple of large stitches, they are now taken off the mourner all together by some members of the family, the rope preventing the sleeves from getting out of place. The whole lot is then laid out underneath the corpse, the arms are introduced into the sleeves, and the buttoning of each of the garments is properly done. The trousers and stockings have been put on beforehand whilst the arranging of the garments on the person of the mourner was going on. A general howling concludes the dressing.

Even if the dead person be a member of the female sex, it is incumbent on the eldest son to first put on the grave clothes. There is no reason to fear he will not be able to get into them. Chinese clothes never fit tight to the body, being as a rule at least twice as spacious as is strictly necessary. In case there are neither sons nor grandsons, this ceremony is performed by the p.68 wife or the eldest daughter-in-law of the deceased, as these persons, like the direct male descendants, stand in the first degree of relationship towards him. And when the dead is unblest with such relations, the clothes are simply fitted into one another without any such intervention of a living person. 


\section{The religious system of China \\ vol. I}

On asking the Chinese why they do not always act in this latter way, the answer invariably runs, that such would prove a total absence of filial devotion. The $L i k i$, they say, has a rescript to this effect :

«When the Ruler of a State is ill and has to drink medicine, his minister should first taste of it ; and when a parent is ill and has to drink medicine, his son should first taste of it (131) ;

- a dutiful child must not only observe the letter of this law, but also its spirit, and consequently apply it to garments destined for the venerable person of a prince and for a father or mother as well. While fulfilling this duty in behalf of a dead person, the child should, however, bear in mind that he is not allowed to pollute holy Mother Earth by bringing her in contact with the grave clothes, or to annoy and oppose bright Heaven, the principal source of all life in nature, by placing objects connected with death openly under his eyes. Therefore he must separate himself from the former divinity by means of a tray and chair, and conceal himself from the view of the latter by wearing a broad-brimmed hat ; and further : ought not a child, whose filial devotion has fallen short in prolonging the days of the author of his life, to hide himself with shame from the sight of the highest power of the Universe ? It is, in fact, customary in China for a son to attribute the death of his parents to his own want of care for their persons and to his shortcomings on the point of filial affection in general.

As soon as the son has played his chief part to the end of this drama, he hastens to swallow, in concert with most of the attending kinsmen, a few mouthfuls of cooked vermicelli, wisely inferring that the long threads of this food must greatly counteract, nay, totally neutralize, the life-shortening influences which the grave clothes may have exercised over his person. This important occupation finished, he joins his fellow-mourners, to assist them in their numerous occupations preparatory to the coffining.

In the event of the dressing having been wholly or partly p.69 performed by hired assistants, these persons lay hands on all the clothes, sheets etc. which were about the corpse previous to the dressing, established custom allotting these things to them as a lawful emolument pertaining to their 


\section{The religious system of China}

vol. I

office ${ }^{1}$. Fashionable families are decidedly opposed to keeping such effects for themselves. Hence, if there are no hired assistants, they give them away to their poor neighbours, or to the first beggar that turns up. As a matter of course, less fastidiousness prevails on this point amongst people who cannot afford to do away with anything that may still be useful. They usually wear the clothes in question without any mental reluctance, as if they had never belonged to a departed person. More often still they choose the golden mean, sending them straightway to a pawnshop, there to swell the nasty stock of unclean articles which fill such establishments.

1 This reminds us of a similar English practice mentioned by Brand (Observations, Customs at Deaths, p. 439) : « Laying out the corpse is an office always performed by women, who claim the linen and other articles about the person of the deceased at the time of performing the ceremony ; and it is thought to be very unlucky to the friends of the person departed, to keep back any portion of these perquisites. » 


\section{CHAPTER IV}

\section{Sacrifices and rites between the dressing and coffining}

p.70 The dressing is followed by an offering of edibles called sî sing, 'taking leave of life'. This name intimates that the family are now becoming convinced the body has really expired, and that they are about to relinquish their hopes of its reviving; so they offer it a parting meal before shutting it up in the coffin, as a proof also that their devotion remains unslackened, in spite of the interference of the King of Terrors.

\section{Fig. 7. Temporary Soul Tablet.}

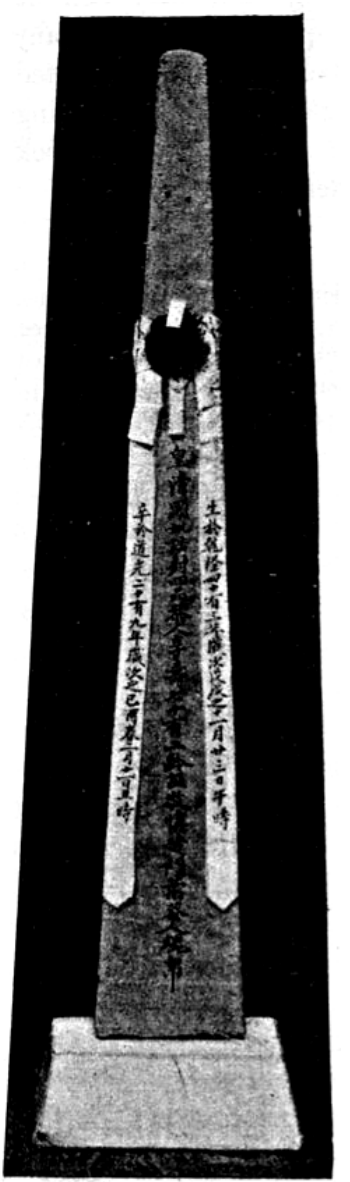

On the table in front of the waterbed on which the dressed corpse is stretched, they arrange a bowl with cooked rice and a couple of dishes of vegetables, as a sort of luncheon, introductory to a more sumptuous meal already in course of preparation in the kitchen. On the table is also to be seen a thin slab of wood, one end of which, from seven to nine centimetres broad, is placed perpendicularly in a small wooden block (Fig. 7). The slab, about half a metre high, tapers away at the top, so that, when seen in front or from behind, the whole reminds us of an obelisk. Both the slab and its support are sheathed on all sides with white silk or, amongst the poor, with bleached linen; a narrow tape of the same material is p.71 pasted along each edge on the front of the slab, and these tapes are respectively inscribed with the dates, to the hour, of the birth and the death of the deceased. His names, titles and age are written in one perpendicular column of characters between these tapes, and over the top of that column is pasted a small rosette of a red material or of floss of silk. Thus, the tablet bears 


\section{The religious system of China \\ vol. I}

such a description of the dead as will, according to Chinese ideas, render it quite fit and proper to be inhabited by the soul : - in fact, as the corpse is going to be concealed in the coffin for ever, the soul, in its weak, unsubstantial state, will soon be badly in need of an artificial body to strengthen it and prevent its dissolution. This curious object, which has an interesting history that will be given in our Second Book, goes by the name of hûn péh, 'silken cloth for the soul'.

But, will the soul really enter this artificial body ? May it not be prevented from doing so by the powers of darkness, perhaps be confined in the terrible hell, about which the Buddhist Church has so much to say ? This important question, weighing heavily on the mind of the family, induces them to employ a priest of that Church at this part of the funeral rites; for, releasing souls from the pangs of hell has always been one of the first articles of the programme of Shâkyamuni's religion in China, and its clergy have invented excellent expedients for carrying it into effect.

Dressed in a plain black or dull grey ceremonial robe, or in a richly embroidered Kâshâya, if the family are rich enough to afford the extra expense which this ceremonial dress of the highest order entails, the priest takes his place before the sacrificial table. He opens the ceremony by pronouncing a few magic formulas (Tantras) composed of Pali or Sanskrit words, which neither he himself, nor anybody else in China understands ; they are nevertheless possessed of wonderfully miraculous power. Then, he chantingly invokes the Bodhisatwa Ti tsang wang ${ }^{1}$, the principal redeeming power residing in hell and placed by the Church at the head of the ten infernal kings, saying :

« O Bodhisatwa of the World of Darkness, Thy glory is difficult to describe, p.72

Realize our hopes by showing Thy true face and diffusing this over every place,

\footnotetext{
1 A detailed monography of this holy being, as well as accounts of those mentioned further on, will be given in a separate Book on Buddhism.
} 


\section{The religious system of China}

vol. I

That the beings on the three lower paths of the six paths of transmigration ${ }^{1}$ may hearken to the glorious Law,

And the ten classes of beings which have been called into existence by the four modes of birth ${ }^{2}$ may bathe their heads with Thy merciful favours.

May the light of Thy precious pearl ${ }^{3}$ shine as far as the roads which lead to the celestial halls,

And Thy metal crosier ${ }^{4}$ knock open the gates of hell !

We sincerely wish the soul of the deceased may enjoy the favour of being introduced (into the regions of bliss),

And on the lotus-terrace ( $i$. e. the Universe) may worship the merciful Honourable Ones (Buddhas and Bodhisatwas).

While chanting this invocation in a slow, monotonous tone of voice, the priest beats at every syllable upon a globular hollow instrument of wood and, at the beginning of every new line, on a metal bell resembling a large goblet without a foot, both instruments standing on the table for the purpose. Now taking up a small circular incense-burner fixed on an horizontal wooden handle, he pronounces with fervour a prayer of the following tenor :

«I salute Ye, Celestial Judges of the three spheres constituting the higher, middle and lower divisions of the Universe; and $\mathrm{Ye}$, host of Kings and nobles of the departments of land and water and of the world of men ? Remember the soul of this dead man, and help it forward in going to the Paradise of the West. I reverently consider that it is a difficult matter to escape existence (lit. birth and death) as a human being or a Dewa, and that this p.73 disembodied soul will have no means to rid itself thereof and come down to this place, unless it be earnestly worshipped without the worshipper allowing his thoughts to

\footnotetext{
1 Those six stages of existence (Sanskr. Gâti) are: Dewar, men, Asuras, infernal beings, Prêtas and animals.

2 To wit, from a uterus, an egg, moisture, and by transformation.

3 Most saints of the Buddhist Church are, in China, represented with a pearl in their forehead, probably standing for the ûrnâ, or white soft hairs between the eyebrows, characteristic of every Buddha.

${ }^{4}$ As chief rescuer of the souls from hall. Ti tsang wang is nearly always represented with the sik thng mentioned on page 55.
} 


\section{The religious system of China}

vol. I

swerve away therefrom. The stores of the holy scriptures of our Church of Buddha contain authentic words suitable for convoking beings, and it behoves me to carefully take these words in my hand and recite them.

Grasping his hand-bell, the handle of which bears on the top a metal knob shaped like a Wajra or magic sceptre of the Church, the priest slowly tolls it, reciting at the same time the following quatrain :

«By means of this tolling bell I issue forth my summons, Doubt not, soul of the deceased, but hearken from afar and understand the meaning thereof,

Mayest Thou, through the Triratna's power, seize hold of it,

And come down this day, at this very moment of my summons, to repair hither.

A miraculous Tantra of a dozen syllables does the rest. The spirit of the dead really turns up and has its olfactory nerves at once gratified by means of a few burning incense-sticks, which the principal mourner raises with both hands on a level with his forehead and then sticks into the ashes of the censer standing in front of the soul-tablet. The priest meanwhile chants :

«In my heart's core I respectfully request that the scent of this stick of incense offered from the heart may pervade the regions where the Law prevails, and that the messengers of Hades may conduct the soul hither !

Thereupon he reads aloud a letter addressed to the soul. It contains the good news that the mourners, So-and-so by name, have erected on the spot, of which the geographical position is circumscribed with great exactness, a tablet p.74 for the occupancy of the spirit, in which it may abide for all ages to come ; further, that a sacrificial meal has been set out in front thereof for its private use.

« Thrice - so sings the priest in conclusion - I invite the soul of the deceased to descend to this place. Soul, come home, enter into Thy seat, and hearken to the words of the Sûtra! O Bodhisatwas and Mahâsatwas who practise the holy scriptures ! 


\section{The religious system of China}

vol. I

Now setting fire to the letter, in order to dispatch it to the soul, the priest proceeds to recite a wonderful canon entitled: The hell-conquering Sûtra. Like most sacred books of the Church, it passes for a reproduction of a sermon pronounced by the Buddha himself. If recited for a full year, so the book itself declares, it exempts all the dead from passing through hell and there beholding the face of Yama, nay, causes them to be introduced straightway into Nirwâna; hence it may be said that its recital is not out of place on the present occasion. To enhance its good effects, a few Tantras are pronounced in addition; and finally come three brief summonses addressed respectively to Amitâbha and Awalôkitêçwara, the chiefs of the Western Paradise, and to Ti tsang wang, that they may help the soul to the enjoyment of everlasting bliss. The magic formula 'Om mane padmê hûm' concludes each of these summonses.

Meanwhile the sacrifice proper has been served on one or two extra tables, arranged for the purpose in front of the one already standing near the corpse. It consists of twelve dishes, for the very good reason that, during the ancient Cheu dynasty, the same number constituted the chief daily meal of a Sovereign, it being said in chapter 4 of the Cheu li (leaf 16) :

« The Sovereign has once a day a full meal, served in twelve pots.

As a rule, those dishes chiefly consist of the following articles :

1. A whole duck, roasted.

2. An entire fowl, roasted.

3. Some dried venison.

4. One or more fishes.

5. The so-called taō tsó or 'pea-dates' : pellets about as large as p.75 marbles, composed of small parched peas mixed up with a very sweet syrup made from barley malt (béh gê ko, 'malt-syrup').

6. Moâ tsó or 'hemp-seed dates', being similar balls to the aforesaid, only the peas are replaced by hemp-seed.

The above two sorts of sweets appear on the table because they are considered very fit to promote the object of the sacrifice, which is to bring the departed soul back to the house. Indeed, the written name for a date tree, or perhaps more correctly a jujube tree (Zizyphus jujuba ?), closely represents a 


\section{The religious system of China \\ vol. I}

reduplication of the character [], 'to come', or the Chinese expression chung lai ; but chung lai also means 'to come again, to return'. In the Pu khüeh, a work written during the Thang dynasty, we read :

«A descendant of the family Yang, Kin by name, was a good oneirocritic. One person having dreamt that a pine was growing before his door, and another that a date tree shot up on the top of his house, Kin laid: "Pines are planted between the tumuli, and the character for date tree represents the idea of coming again, which in its turn symbolizes calling the soul". Both men died (132).

And the historical encyclopedia of the $11^{\text {th }}$ century, entitled Ch'eh $f u$ yuen kwei, says :

« Li Yuh, who was a nobleman of the Imperial Banqueting Court, one day fell asleep during the daytime and dreamt that he ate pea-dates. On awaking, he felt ill and said to his intimate friend : "I have been informed that the date tree is a reduplication of the word 'to come' and therefore is the symbol of calling the soul ; my vital spirits now feel oppressed and dejected, so, I shall not escape it". In the summer of the fifth year of the Thien-fuh period (A. D. 940) he breathed his last $(\underline{133}) \cdot$ p.76

7. 'Red rolls', âng în. Round cakes of flour, convex at the top, flat at the bottom.

8. Dried shell-meat from univalves. This appears amongst the sacrificial articles because its popular name ōng lê is composed of two syllables which happen to have synonyms respectively in another ōng, meaning 'to thrive, to prosper', and another lê, which signifies 'glory, opulence'. The food is accordingly very fit to promote the welfare of the soul in the next world.

9. A pine-apple, with its crown and a few leaves. It is by no means necessary that it should be ripe or full-sized, because it plays a part amongst the offerings merely on account of its name, which reads ōng lâi, 'pear of prosperity'. Already the word for pear by itself includes a great deal of good luck, as the written character representing it, viz. [ab], is composed of [a], 'a tree', and [b], 'advantageous, profitable, prosperous, happy, auspicious, beneficial etc.' 


\section{The religious system of China}

vol. I

10. 'Hempseed-cakes', moâ tsî, as many as the years of age of the deceased. They are small cakes, soft and round, made of rice flour and hempseed, having sweets inside composed of sugar and pease meal. People are so firmly convinced that the dead are extremely fond of them, that they dare not let them be wanting at the table. Once upon a time, they say, a mandarin, doing justice in his court, suddenly fell asleep. On re-opening his eyes, he related that he had been in a house, where the inmates were serving a sacrificial meal to their ancestors. Perceiving amongst the offerings a dish full of hempseed-cakes and being endowed by nature with a strong liking for this delicious food, he had helped himself immediately and devoured a good many of them. None of the by-standers would have paid much attention to this dream, had not all perceived very distinct traces of the glutinous nutriment on the lips and cheeks of their master. Now the mandarin could, of course, not help sending his underlings in all directions to see whether there really existed a house like the one he had dreamt of ; and, indeed, they soon returned to report that the family in question had been found. All the particulars given by the messengers, corresponding in every respect with what the mandarin had himself seen during his somnambulism, there remained no doubt that he was a re-incarnated forefather of that family ; p.77 which was confirmed when they told him they had sacrificed the cakes in question expressly because one of their ancestors had been extremely fond of them. Another wise inference was drawn from the event by every one endowed with common sense : souls are fond of hempseed cakes; and as these will consequently wet their appetite at any moment, they may be used with advantage on occasions like the present, when a soul is desired to come and take up its abode in a tablet, and reside in the house with the family for ever.

As soon as the sacrificial articles are properly arranged in front of the dead, the Buddhist priest resumes his functions. Taking in his hand a small tin bowl of water, representing the Pâtra or alms-bowl of the mendicant friars of the ancient Church, he solemnly sings :

The Amrtâ of the willow of the Bodhisatwas

Is so powerful that one drop of it can, all around in the ten parts of the Universe, 


\section{The religious system of China}

vol. I

Completely do away with the filth and dirt of rancid flesh,

And, besides, can keep the altars and places of worship perfectly clean.

Dipping his finger, or a sprig of a banian or pomegranate tree, in the water, he now sprinkles a few drops over the offerings, and subsequently over the corpse, the by-standers, and the walls of the hall. Thus, through the power of the sacred ambrosia, everybody and everything are cleansed from inauspicious influences resulting front death, and the soul of the deceased is enabled to appear before its ancestors in a state of perfect purity. Hence the ceremony is called tsing sin, 'purifying the body'. It is followed by a cleansing process of another kind. Having grasped his above-mentioned hand censer, in which some of the 'purifying incense' spoken of on p. 33 now lies smouldering, the priest wields this instrument over, under, and along the sides of the corpse, approaching it also to the walls and all the conspicuous objects around. Meanwhile the mourners, arranged before the sacrificial table, present the articles by offering each, in the order of rank and seniority, two incense-sticks and thereupon making three prostrations, at each of p.78 which the forehead is bowed four times to the ground. The number of incense-sticks and bows should, in worshipping a dead body, be even, that is to say, it must belong to the element of death Yin, three sticks and three times three bows being specially reserved for disembodied souls, gods and living human beings (comp. page 65).

Fig. 8. Sheet of Treasury Money.

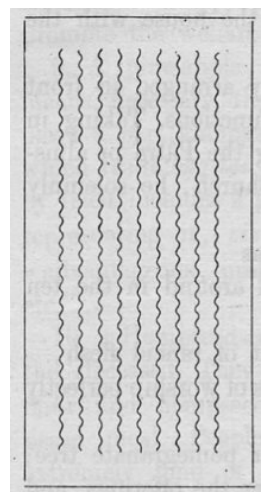

This solemn and bounteous sacrifice is not deemed complete without a large bonfire of paper. In a chop for the special sale of such mock money, of which there are many in every Chinese town, great quantities of white sheets with parallel rows of small scalloped incisions as represented in miniature size in the annexed figure, have been previously purchased by the family in yellow parcels containing one hundred each. Every sheet of this so-called 'treasury money', khò $t s i^{n}$, is an imitation of regular rows of metal coins ; so, it is easy to calculate that each parcel represents a considerable amount of currency in the next world. The whole lot is carefully packed up in small trunks of bamboo and paper; and 


\section{The religious system of China}

vol. I

these are set in array with similar boxes of larger dimensions filled with paper ingots of precious metals, which the reader already knows from page $25 \mathrm{seq}$. A paper padlock sufficiently protects each box against being opened by unauthorized hands; moreover, they are all carefully sealed by means of a strip of paper pasted on the frontside from top to bottom and bearing, besides the names etc. of the dead, the seal of the officiating priest.

At the side of each trunk stand two puppets of paper and bamboo, which have to carry the treasures into the other world. A so-called khò koan or 'treasury officer' of the same material and make, is placed upon a table in the quality of general headman of these bearers, and intrusted with the care of the money. Himself and eleven colleagues form a set of spirits who devote themselves exclusively to this sort of work, not merely for the benefit of the dead, but also for the sake of their own purse, as the management of other people's money matters is, both in terrestrial and p.79 subterranean China, a business which pays well. Each spirit corresponds to the name of an animal of the duodenary cycle described on page 44 and, as such, has to attend to the treasury money of all the souls born in the year of that same animal : a very ingenious regulation indeed, as it enables people to know which treasurer to evoke in all cases of death. Calling upon invisible beings without knowing their names or titles is generally considered by the Chinese a very difficult task, bordering almost on the impossible.

The evoking is done by the priest. Tolling his magic bell and reciting the requisite formularies specially prescribed for such occasions, which bear a great similarity to those mentioned above for evoking the soul, he calls the attention of the spirit to the puppet provided for its occupancy, as also to some eatables placed on the table on purpose to enable it to replenish its stomach. Amongst the dishes, one containing a pig's liver stands conspicuous. Indeed, the family wisely surmise that this food, called $k^{n} a^{n}$ in their mother tongue, must, if consumed by the treasury officer, favorably influence his own 'heart and liver' sim $\mathrm{koa}^{n}$, that is to say, his organs of memory, thoughtfulness and affection, according to Chinese ideas. A treasurer who has eaten liver will consequently be less likely to neglect his duty towards the dead than one who has not partaken of such food. 


\section{The religious system of China}

vol. I

As soon as the treasurer has descended into his image, the mourners advance towards the same to offer incense, and respectfully bow their heads three times to the floor. In many cases, the principal mourner also pours spirits into a few cups standing on the table, that the unseen being may exhilirate his mind by drinking of them. Meanwhile, the priest reads aloud a letter addressed to the treasurer, which informs him of some things highly important for him to know, such as what he is wanted to do ; the names, age etc. of the deceased, lest he should mistake the latter for another person ; the names etc. of the priest who arranges the financial transaction, and the like.

The bearers of the boxes are also liberally attended to. Having been arranged in a circle on the ground, with some eatables and cups of wine in their midst, they are politely, but urgently, invited by one of the mourners to help themselves. Advance wages in the shape of a few paper sheets are, moreover, suspended around p.80 the neck of each, just as in the case of the palankeen bearers spoken of on page 29.

To all the performances of the priest, in not a few cases solemnity is given by a few musicians, specially engaged to refresh the soul, the treasurer, and the trunk-bearers with the dulcet tones of their discordant instruments. In the end, the whole collection of boxes is set on fire. Those containing the 'treasury money' are burnt a little apart from the others, as the ashes must be carefully collected, wrapped up in paper and placed, either inside the coffin or by the side of it, in the grave. In general, the burning is done in the courtyard, or even in the street, to prevent the house from catching fire. The treasurer and the bearers are likewise committed to the flames, as also a goodly quantity of yellow mock money for their special use, and the abovementioned letter addressed to the treasurer. All the while the crackling of the bamboo splints and the noise of the fire are drowned by the music, the hand bell of the priest, who continues his incantations with unabated zeal, and the lamentations of the mourners, who are on their knees as near the pile of flames as the heat will allow.

As we have seen, the treasury money plays a very prominent part in this ingenious remittance of precious metal and cash money to the other world. 


\section{The religious system of China}

vol. I

And not without a good reason. It is, indeed, designed for enabling the soul to liquidate its old debts there, which it cannot properly do without a large quantity of small coin. The reader must bear in mind, that the prevailing popular notions ascribe every case of birth upon this earth to the release of a soul from Hades, which redemption is, however, never granted unless a heavy ransom is paid by this soul itself to Yama and his underlings. Now, as souls are, in general, very poor, nearly all of them have to borrow from their fellow manes, if they desire to be re-incarnated on earth. Every Chinese is, of course, sure his dead may have commenced their terrestrial career under such circumstances. The soul, returning now to Hades, will consequently at once be assailed there by a host of creditors, who are all anxious to collect the funds necessary for their own release, and resolute to have no mercy upon it, if they find it unwilling or unable to pay. It is, in consequence hereof, certainly very wise and dutiful on the part of the surviving kinsmen to send the soul a rich stock of bullion out of which to settle its old liabilities; but greater still is the sagacity they display in the boxes of treasury money. In fact, the small coin these contain will p.81 help the soul to settle its accounts more quickly, and thus enable it to rid itself of its dunners in less time; moreover, it saves it the troublesome work of changing the bullion and keeps it out of the clutches of money-changers, who, in the Chinese hell no less than in the Chinese empire, never feel any qualms of conscience when they fall in with an opportunity to fleece and oppress a fellow creature hunted down by impatient creditors.

Already many, many ages ago, wise men, whose names are, alas, lost to posterity, have discovered after careful researches that the quantity of treasury money required by a dead man to satisfy his dunners stands in immediate relation to the year of his birth. This important fact once ascertained, these philosophers, assiduously pursuing their investigations in the same direction, have gloriously succeeded in fixing the minimum quantity for each year of the duodenary cycle of animals (see p. 44). And although people know nothing of the principles upon which the calculations are based, yet everybody firmly sticks to the ciphers of those sages, with the blindest confidence in their accuracy. They are, pasted on a small board, suspended before everybody's eyes in each shop where such paper is sold, and may 


\section{The religious system of China}

vol. I

without extra payment be inspected there by any customer who does not know the ciphers by heart or has no such placard-board of his own at home - a precious legacy of past generations of his ancestors. We have inspected these lists ourselves, and learned from them that the highest and the lowest amount, viz. 320,000 and 60,000 coins, are required for persons born respectively in an ox-year and a monkey-year. Each sheet representing one hundred coins, and one hundred sheets making a parcel, we arrive at 32 and 6 parcels, which, according to the quality of the paper, vary in price between 1 and $2 \frac{1}{2}$ Mexican dollar-cents a parcel, terrestrial money. Very dutiful mourners, however, living in easy circumstances, usually go far beyond the minimum. They even burn three, five and seven times as much, carefully avoiding an even multiple, for reasons set forth on page 65 .

When the offerings have been standing for a while and the dinner time of the living draws near, everything is removed to be consumed by the mourners and those who assist them during that very busy day. The priest, having pocketed his fee, retires, rejoicing in the pleasant prospect, opened to him by the family, of having his services invoked again for the celebration of other lucrative ceremonies sooner or later during the course of the mourning rites.

It remains now to be considered, what place the sacrifice ${ }_{p .82}$ described in the foregoing pages occupies in the series of funeral rites. There are many reasons for believing it is offered to the corpse. On page 29 it has been stated that the family continue to feed the body after death, and as, moreover, the coffining marks the moment at which the hope of revival is given up (see page 70), it can scarcely appear probable that sacrifices preceding the coffining are addressed to the disembodied soul. The fact that the ashes of the paper are carefully collected in order to be placed in the coffin or outside it in the grave, likewise points to a sacrifice to the body ; indeed, people call the whole ceremony, inclusive of the offering of eatables, taî suî-sin khò, 'burying a treasury which follows the corpse'. Finally, the following interesting passage occurring in ch. 13 of the Yiu-yang tsah tsu, is clear evidence that even of old sacrifices were offered to the body until the very moment of closing the coffin : 


\section{The religious system of China}

vol. I

«It is a funeral rite of the generations of latter times to place meat, cooked rice, millet and spirits in front of the coffin when the corpse has been placed in it and the lid is affixed, and then to shake the lid and knock at the coffin, calling out the name and title of the deceased and exclaiming : "Stand up, and eat!" Having repeated this three times, they stop.

But, on the other hand, the ceremonial performed by the Buddhist priest affords conclusive evidence that the eatables are conceived of as offered to the soul, even serving as a bait to allure the soul into its tablet. And, besides, the popular ideas concerning the destination of the paper money clearly point to a belief that the same is remitted to the soul. The conclusion therefore is, that the sacrifice bears a twofold character, or that it is a transition from sacrifices to the body to sacrifices to the disembodied soul. It may even be suggested that the introductory part of it, described on page 70 , is destined for the body, and the subsequent fuller meal for the soul.

It ought to be observed, that the burning of paper money at this part of the funeral rites is by no means recurred to in every case of death. Most families are sure from the very beginning that they will soon celebrate a solemn mass for the repose of the p.83 soul, during which the dead will for several days be enriched with so much paper money as to render a previous burning of treasures quite superfluous. But if the family foresee that circumstances will compel them to defer that mass for a long time, they always duly perform the burnt-sacrifice, it being utterly inconsistent with the rules of filial devotion to leave the soul of a father or mother longer than is strictly necessary helpless in the hands of its dunners in Hades.

In the said requiem-mass Buddhist rites play a prominent part. Its description must therefore be deferred to our Book on Buddhism, in which it will find a place amongst the chapters devoted to the position this religion holds amongst the laity. The reader will find there also an account of a curious ceremony, performed in the exceptional case of the dead being a woman who has died in childbed, and which has for its object to help her soul out of hell, where it has been plunged into a tank full of blood, to atone for the uncleanness incurred by her confinement. Now this ceremony is, in the 


\section{The religious system of China \\ vol. I}

case of such a woman, generally celebrated at the present period of the funeral rites, being inserted somewhere between the ceremonies which we saw the priest perform to effect the release of the soul from the powers of Tartarus. This by the way for the sake of completeness.

Sacrificial ceremonies connected with the dressing of the corpse were in vogue already in the age of Cheu. Indeed, in its elaborate account of the funeral rites for ordinary officers the $I$ li describes them in detail. It may be useful to reproduce here what it says about them, as no doubt the work places before us the most ancient prototype of those rites to be found in the literature of China.

Having described the first part of the dressing, which took place in the back-chamber, the I li says :

«On the east of the hall, below stairs, they set out dried meat, pickled meat, must and spirits. Linen of coarse or fine texture, to be used for covering these offerings, is placed in a basket on the east side of the articles displayed; and a wash-basin with ewer are put down on the east of those articles, with a towel (134). They further place one threelegged caldron outside the ts'in gate, near the eastern gate-room, a little southward. Its frontside is turned to the west. It p.84 holds a sacrificial pig, to wit, the four limbs (hams and shoulder-pieces) from which the hoofs have been removed, the two rib-pieces, the spine, and the lungs. They also place on the spot a carrying pole to pass through the ears of the caldron, and a cover for the caldron, which has its end on the west side ; moreover, an unornamented stand is placed on the west of the caldron, in a direction from east to west, and a ladle is deposed upon it with its handle pointing eastward (135).

Upon this follows a description of the second part of the clothing ceremonies or the so-called 'slighter dressing', which took place in the hall, and then the $I$ li continues:

« Now follows the presentation of the sacrificial articles. The men who have to lift up the caldron with the viands wash their hands. The one on the right grasps the ladle and holds it downwards; the other on the left side takes the stand and holds it athwart; and so (carrying the 


\section{The religious system of China \\ vol. I}

caldron between them) they enter the gate and put it down in front of the eastern steps, turning its front side towards the west. The stand they place with its front side to the north (136).

« The man on the right, taking the ladle in his left hand, pulls the pole out of the ears of the caldron and likewise takes it in his left hand. Then he places the cover on the north of the caldron, lays the pole upon it and, without sitting down, scoops out the contents of the caldron and places them on the stand. The two hams he lays down on the stand at each end, the two shoulder-pieces next to them; then come the rib-pieces, and the spine with the lungs are put in the midst. Having placed a cover over the whole and made the roots (joints of the bones ?) to stick out, the men take up the stand and remain waiting on the spot (137).

"The Invoker after the manner of the Hia dynasty ${ }^{1}$ and his p. 85 functionaries now wash their hands. Taking the must, he places himself at the head of the functionaries who carry the spirits : those with the dried meat, the pickled meat and the stand of viands follow behind, and in this order they ascend the eastern steps, during which the male persons attending stamp their feet. The overseers of the waste and cultivated fields remove the caldron, whilst the man holding the linen for covering the offerings stations himself at the foot of the eastern steps (138).

«The articles are put down to the east of the corpse in the following manner. The men with the must and spirits having taken their station with their faces towards the north, the principal one (to wit he with the must) on the west side of the other, the pot with pickled meat is put down, and then the stand with the viands is placed on the east of this pot. (The men who performed this work) having taken their station to the north of the stand, the principal one on the west side, the must and spirits are placed to the south of the pot, whereupon the Invoker receives the linen (from the hands of the man at the foot of the steps) and places it over the cups. Then they all pass by the feet of the 


\section{The religious system of China}

vol. I

corpse and descend by the western steps, the female mourners meanwhile stamping their feet; and when the sacrificers walk eastward along the southern side of the double ${ }^{2}$, the male mourners stamp their feet (139).

Preparing coins for consulting the deceased.

In the course of the ceremonies described in this charter, the mourners provide two large copper coins, imitations of a kind which seem to have been current in China in bygone centuries, and, having fastened them to the opposite ends of a thin cord of red silk, hang them over one ear of the deceased. The consequence p.86 is, the coins after a time become so thoroughly imbued with the essence of the soul, that they can do excellent service in divulging its will and wishes. Whenever, from this moment, the family want to know the opinion of the deceased on a matter directly concerning himself, or of interest to the offspring, some one explains the circumstances before the coffin or, after the burial, before the soul-tablet, and thereupon puts his question in such terms as to allow the soul to confine its answer to a simple yes or no. Then he holds the coins for a moment or two over the smoke of the incense, which is burning on the spot to gratify the nostrils of the soul and is believed to be also imbued with its essence, and finally drops them, to read the answer from the position in which they lie on the floor. If either the two obverses or the two reverses are uppermost, the answer is a decided negative; but one obverse and one reverse signify an affirmative. Henceforth these divining coins are carefully kept on the spot, not only to have them always ready for use, but more especially that they may be continuously pervaded with fresh afflatus from the dead. People therefore prefer hanging them on the incense-burner. In many cases they are used for 25 or 26 months, that is to say, until the mourning period has entirely elapsed for all members of the family.

1 Comp. Page 17, note.

2 A very rough human image, doing duty as a seat for the soul, which was put up in the middle of the court-yard. Its history will be given in our Second Book. This was evidently the prototype of the modern hûn péh described en page 70 seq. 


\section{The religious system of China \\ vol. I}

\section{CHAPTER V \\ The coffining}

p.87 Whether the coffin has been bought after the decease or, as in the case of aged people, was provided already during life and deposited somewhere out of doors for safe keeping, custom at all events requires it to be brought home ceremoniously. An even number of friends or distant relatives are appointed for this work, which is called tsih pán, 'to receive the coffin'. Among the wealthy there are sometimes no less than six or eight of such so-called tsiáng pán or 'managers of the coffin'.

Repairing to the shop where the coffin has been purchased, or to the place where it is stored away, these men attire themselves in a mourning dress of plain white linen, which has been taken to the spot for the purpose, and have the receptacle for the dead carried off. Eight coolies or, if it is very heavy, sixteen, carry it on their shoulders by means of a large rafter, which is tied lengthwise over the lid by ropes passing crosswise underneath the bottom. A band of musicians opens the procession. Next comes the bearer of a red umbrella of state, two men each carrying a large gong, and, in many cases, either two or four beggarly-looking individuals, who have to figure as lictors. In this quality they wear the characteristic head-gear of this class of persons, namely high hats either red or black, and wield ratans twisted into each other, or halves of a bamboo, such as are used for flogging in the courts. Having to imitate the real policemen escorting a mandarin when outside his Yamen, they, like these men, slowly exclaim at intervals at the top of their voices iû o. o. o., in order to exhort people to respectfully keep out of the way. The 'managers of the coffin' come after them, followed by the coffin. This is carried with the foot-end foreward. It bears a long, narrow piece of red cloth, placed over the lid, and also a couple of large flowers of gilt or coloured paper, p.88 such things being all very useful to keep at a distance the influences of the spirits of darkness. 


\section{The religious system of China}

vol. I

Meanwhile all the mourners, males as well as females, leave the mortuary house and go up the street for a little distance, in order to meet the coffin. They wear deep mourning clothes of the coarsest hemp, or slighter mourning, each in accordance with his degree of relationship. As soon as the procession comes in sight they all kneel down, bursting into loud wailings of woe, while at the same time the quasi lictors send forth an awe-inspiring iû 0.0 .0 . through the street. At the spot where the mourners lie prostrate the bearers of the coffin halt for a moment to take breath, thus allowing one of the family to place a string of copper coins, a small quantity of uncooked rice and a few pieces of firewood or charcoal on the lid. At the same time a couple of other men hastily light some mock money on the pavement, in order to give the evil spirits, that hover about the spot, something to prey upon and so cause them to forget all the bad intentions the sight of the coffin may excite in them, such as sneaking into the house and disturbing the soul. After a while, the procession and the wailing mourners in the rear enter the dwelling through the main entrance, the sonorous peals given forth by the gongs, the harsh discordant tones of the music, the exclamations of the lictors and the vociferation of the wailers producing a deafening hubbub, which is very edifying in the opinion of the Chinese.

The coffin having been set down in the court-yard or in the hall, the red cloth and the flowers are removed from it, as well as the money, the rice and the fuel. By placing the three last-named articles on the coffin the family have caused this to introduce an abundance of the first necessities of life into the house, and thus they have ingeniously removed all chances of their being reduced to poverty in consequence of the case of death. The lid having been subsequently removed, a quantity of clippings of paper, some parcels of slacked lime and a loose board fitting into the case, all necessaries for the coffining procured at the coffin-manufacturer's, are taken out, and the empty case is placed by the bearers in front of the water-bed, the head pointing towards the same. In order to facilitate its being lifted up afterwards, when the coffining is finished, it is laid on a pair of wooden logs or, in most cases, on two huge wooden mallets which do duty in every household as pestles for pounding and husking rite in large mortars. 


\section{The religious system of China}

vol. I

While the coffin is being prepared for receiving the corpse, the p.89 musicians, who have stationed themselves somewhere in the lower part of the hall, play their clarinets, cymbals and drums without ever ceasing, sparing neither their lips nor their hands. And the lictors send forth a long-protracted iû o. o. o. at every important turn of the proceedings. The mourners abstain from wailing all the while, because manifestations of woe and distress might cause real woe and distress to be enclosed in the coffin, and so bring bad luck not only on the dead, but also on his descendants, the fate of whom, as our readers know, is most intimately bound up with the grave of their ancestor.

In the popular tongue of Amoy, the coolies who bear the coffin to the mortuary house are styled kioh hu, 'foot-men', kang kioh, 'working feet', or kioh-á kang, 'foot-workers'. Indeed, the carrying of heavy loads, by which they gain their livelihood, demands special exertion of the legs and feet. Small groups of these men, headed, like every group in China, by a leader, may regularly be seen loitering about the coffin-shops, awaiting employers. When a group has been hired to take a coffin to a mortuary house, its headman usually acts an important part in the coffining. His first work is to slowly strew the ashes, which the mourners have collected at their neighbours (see p. 24), in the bottom of the coffin, saying in a loud tone of voice : Iā hé-hu, hō lí-êe kiáng-sun pù kuí-á tu, "I scatter ashes to cause your sons and grandsons to acquire piles of wealth". All the attendants then exclaim in chorus : Hó ah, hó ah a strong affirmative expression, meaning : Very well! Oh yes! Certainly! Ashes are in China a symbol of domestic welfare, as no home can be poor where a fire is burning and food is cooked.

After this, the headman scatters a handful of small iron nails in the coffin, saying : Iā ting, hō lí-ê kiáng-sun ch'ut ting, "I strew nails, in order that your sons and grandsons may procreate male offspring". The chorus responds with a loud Hó ah as before. The word ting, 'a nail', and its written form [] happen to mean also a male individual, especially in counting the members of a family, the inhabitants of a ward, etc. Then follows a handful of hemp-seeds and a handful of peas, accompanied by the phrases : Iā moâ, hō p.90 lí-ê kiáng-sun tsīn tsōe nā ch'in-ch'iüng moâ ; iā taō, hō lí-ê kiáng-sun hó aō, "I strew hemp-seeds, to cause your male issue to become as numerous as the 


\section{The religious system of China}

vol. I

seeds of the hemp plant ; I scatter peas, in order that your descendants shall be blessed with a large posterity". Wheat, millet and pady then follow in like manner, also, in many cases, a small quantity of so-called 'red yeast', âng khak, being a granular preparation from rice, which, when mixed with dough, causes this to ferment up to three or four times the original size. We have here an expedient intended to cause the posterity not only to have plenty of food for all time to come, but also to multiply themselves over and over again like grains and pease sown in the fields, seeing their numbers swell like dough under the influence of barm. So, the whole preparation of the coffin is only a broad application of the rule given on page 57, that things of good omen, when placed in a grave, cause the benefits they express to fall as a real blessing to the offspring of the deceased. The reader will now understand that the headman of the coolies has good reasons for loudly expressing himself at every point of his programme in the manner described. The expected effects are thus set in working order at once, as otherwise they might very probably remain latent. And the affirmative outcries of the mourners are very useful too, because they greatly enhance the efficacy of the headman's words.

Having thus sown abundance, luck and posterity for the family, the headman places in the coffin a good quantity of refuse of pith, or, as it is commonly called in Europe, of rice-paper. It is obtained from the shops where artificial flowers and other fancy articles of the kind are manufactured and sold. There is no symbolic meaning attached to it ; yet the headman, on strewing it, says : Iā tsó-ts'ùi, hō lí-ê kiáng-sun toā kùi, "I scatter refuse of pith to cause your sons and grandsons to become grand and of high rank". Finally come long strips of paper cuttings, being refuse from printing establishments and paper-shops, and also some parcels of lime, intended, like the pith and the paper, to absorb the fluid products of decay.

Everything is now covered with the before-mentioned loose board, p.91 fitting in the coffin at a little distance from the bottom. In this board are seven holes arranged like the stars of the Great Bear, or seven painted circles, sometimes with and sometimes without a small hole in the centre of each ; it is known as the 'seven stars board', ch'ít ch'ing pán. The poor rarely 


\section{The religious system of China \\ vol. I}

use it, but it is scarcely ever wanting in burials of aged persons. Its meaning and object will be explained in the second part of this Book, ch. IV.

Over this board comes a mattress, stuffed with paper cuttings instead of unspun cotton, as the last named material must not be buried with the dead (see p. 48). Then follows a kind of mat made of the pith of water rushes, having also for its object the absorption of the products of decay. It is made of threads of pith, just about as long as the coffin is wide, placed close to one another and connected by two or three couples of red cords which are twisted lengthwise through them. Over this mat is spread a second one of ordinary make, as also a small pillow for the head, not differing from those in use among the living. This pillow is made of bamboo and wicker work, and looks like a small block.

Now the coffin is deemed fit to receive the corpse. But before the latter is lifted off the water-bed to be placed in its last abode, the mourners put a handful of ordinary coppers into its sleeve and gently shake them out again, causing them to drop into a bowl or rice measure which one of the sons, in a kneeling position, holds up for the purpose ; finally the sons divide the money amongst them. This proceeding is intimately connected with the doctrine, prevalent since the most ancient times, that everything a person possesses continues to be his after death (camp. page 27). Dutiful children would not be entitled to take possession of their parents' goods, if the latter had not distributed the same beforehand amongst them with their own hands; and as, in China, "parents are not in the habit of undressing before going to bed", the ceremony described has been invented to meet the difficulty. It is known as páng ch'iú-bé $t s i^{n}$, 'dropping money from the end of the arm'.

Assisted by the mourners, the headman of the coolies now passes a long strip of white cotton cloth underneath the corpse and ties the ends firmly together on the breast, lest the arms should hang down when the body is raised. Then he seizes the knot; the sons take hold of the head and shoulders, the daughters of the feet, p.92 the daughters-in-law support the body in the middle, and so the dead man is placed straightway in the coffin. Having drawn away the strip of cloth, the headman receives a fee of money as an extra reward for his excellent services, and then he stretches a cord 


\section{The religious system of China}

vol. I

over the middle of both ends of the coffin, to ascertain whether the corpse is placed exactly in the middle. Finally he puts small articles on the corpse, such as may be of use in the next world, or such as the dead man set a value on in his lifetime. Thus a man is provided with a pocket handkerchief, a fan or, if he has been accustomed to smoke, a tobacco pipe and pouch; a person of learning with a pencil, a stone on which to rub his ink, and other writing materials ; a woman simply with a pocket handkerchief. In the case of a child, the sorrowing mother rarely neglects to put in some of the toys her darling was particularly fond of playing with. And if the dead man be a mandarin or a graduate, a copy of his brevet, written out on purpose for this occasion, is placed on his breast in a small pocket fastened around his neck, in order to provide him with the means of establishing the identity of his elevated personage in the next world. But this measure is seldom taken by families of an ultra orthodox turn of mind, as they are generally much under the influence of the warfares which the literati are in the habit of waging from time to time with great zeal against the contamination and desecration of lettered paper.

It is also customary with those who can afford the expense, to put one or more pearls or precious stones into the mouth of the dead man or to affix such costly objects to his head or clothes. The alleged reason for this practice, which is very ancient, is to retard the putrefaction of the corpse ; besides, pearls and gems may serve the departed soul as torches on its rambles through the dark regions beyond this world. In the third chapter of the second part of this Book this interesting custom will be closely considered in both its ancient and modern forms, and its origin and meeting accounted for.

The coffin being thus properly provided with the principal articles of direct use or necessity, the empty space is tightly filled up with parcels of lime, mock paper money and cuttings of paper, so that not even the roughest shaking will displace the corpse. The mourners and other attendants meanwhile watch closely every movement of the headman, lending him a helping hand when necessary and carefully watching that neither he nor his coolies pocket any of the ornaments. A white sheet on which a red one of smaller dimensions is stitched is now spread over the corpse and made $p_{.93}$ to cover the face. Next comes one pair of large trousers and then a small pair, 


\section{The religious system of China}

vol. I

both stuffed with ingots of gold and silver paper. These are expected to enormously enrich the dead and his offspring. Indeed, as the native word for trousers, khò, sounds quite the same as that for treasury, and its written form [ab] is, moreover, composed of [a] 'clothes', plus [b], 'treasury', there can be no doubt that such articles of dress, large and small, when stuffed with paper imitations of precious metal and placed in the grave, will become real treasuries, large and small, full of gold and silver, in the World of Shades.

The two paper slaves mentioned on page 24 are now placed at the feet of the dead. A small mirror or, in case of the poor, a round piece of white iron is always deposited on the corpse to serve it as a light in the grave ; it is called tsiō sin kiàng, 'mirror to light the corpse'. Finally comes a narrow sheet of linen of the commonest kind, about half as long as the coffin. It bears the rough outlines of a human figure at full length, drawn in black ink, male or female according to the sex of the deceased. Such jia sin hoan or 'banners covering the body' are always ready for sale in the shops for a few coppers.

A great part of the inhabitants of Amoy, especially those who are descended from settlers from other parts of the province, are in the habit of swathing their dead in strips of white linen or cotton, a proceeding which they call liém tsó, 'to clothe the dead with bands'. This is done as follows. As soon as the coffin is ready to receive the corpse, the lid is placed upon it, upside down. Then a number of the said strips are arranged lengthwise over it, and a certain number cross-wise; the dressed corpse is placed upon them and covered with the double shroud mentioned above, and then the swathings are wound tightly around it, so that the whole has the appearance of a white net on a red ground. The lid with the corpse is then moved aside and the latter transferred into the case. This custom is also of very old standing. Both the $I \mathrm{li}$ and the $\mathrm{Li}$ ki make distinct mention of it, as will be seen in the fifth chapter of the second part of this Book, in our account of the dressing of deceased officers during the Cheu dynasty.

Thus swathing the corpse, which strongly reminds us of a similar old Egyptian practice, is also prevalent at Fuhchow, the capital of p.94 Fuhkien province. Mr. Doolittle (140) describes the manner in which it is done there in the following words : 


\section{The religious system of China}

vol. I

«After the grave clothes have been put on the corpse, it is tightly bound around with several pieces of cloth, usually two of which are white, and one is red. The white cloth comes next to the clothing. Some or all of it is torn up into strips, and, after being wound around the corpse in a certain manner, is tied into a kind of knot, which is considered auspicious or an omen of good ${ }^{1}$. The body is all covered with these auspicious knots. Over the white cloth, or the white silk, if the family can afford it, is put the red cloth, similarly torn into strips, and knotted. The two ends of the red cloth or the red silk are usually cut off, one piece being given to the eldest son, which he divides among his brothers. The other is sometimes given to the sons-in-law of the dead, each having a little piece. This is regarded as an omen of good to those who obtain it.

When the lid is about to be placed on the coffin, most of the by-standers not belonging to the nearest kindred retire a few steps, or even make off for the side apartments, as it is dangerous to health and detrimental to good luck to have one's shadow enclosed in a coffin. And all the women in the familyway mount on a bench or chair, in order to protect themselves against the danger of incurring a miscarriage. Their national philosophy teaches them that, at the coffining, the kwei of the dead or, in other words, such parts of the soul as partake of the nature of the element Yin, return to the earth from which they originally sprung; hence, unless the said precaution is taken, those kwei may easily pass out of the ground into their bodies and there destroy the weak germs of life, which the opposite Yang element has placed in their wombs.

A final attempt is now made to resuscitate the dead. The tablet of the soul is placed on the breast of the corpse, and the eldest son kneeling down by the side of the coffin exclaims : "Father (or mother) stand up !" After this vain endeavour to re-unite soul and body, the son respectfully places the tablet again upon the table. Meanwhile the elder females address words of endearment p.95 to the deceased, to set his mind at ease about the future.

\footnotetext{
1 The character for knot, [ab], is composed of [a], 'silk', and [b], 'happiness', and is, moreover, pronounced exactly like this last component.
} 


\section{The religious system of China}

vol. I

Promising him to take proper care of his burial and tomb, and to duly offer the regular sacrifices to his soul, which are prescribed by custom ; they also urgently beseech him to remain a watchful patron-divinity of the family for ever, to protect them from evil and to deal out blessings among them for all ages to come.

An abundant quantity of lime mixed with oil of the thung tree 1 , forming a kind of putty which after a short lapse of time becomes very hard, is now put on the edge of the case on each of the four sides, and the lid laid in its place. Only two nails, or, in case the coffin is composed of very substantial boards, two big iron pins are used, one in the middle of each long side. In most instances, a small piece of red cloth is fastened on along with each spike, to do service in keeping disastrous influences at a distance from the coffin. While driving the nails into the wood, the headman of the coolies renders the work useful for the increase of the family by saying repeatedly: Ting ting, hō lí-ê kiáng-sun ch'ut ting, "I drive in the nails, thus to cause your sons and grandsons to bring forth male offspring". In the end, case and lid are hermetically secured together by means of four wooden pegs shaped like the figure $\Omega$, which fit very tight in excavations of the same shape chiseled out just over the seams, two on each long side.

The above description of the ceremonies of coffining affords unimpeachable evidence that spoken words are far from being regarded by the Chinese as mere hollow sounds. On the contrary, they are believed to be endowed with a great deal of power over the fate of the living. Hence it cannot be wondered at that the people are generally averse from calling death and matters relating to it by their true names. Coffining a body is therefore, in Amoy, scarcely ever designated by the term lóh koan-ts'â, which is the proper expression in the vernacular language, but is nearly always called siu, which means 'to put away, to conceal, to put out of sight', or siu bát, 'to close up, to shut tight'. Scholars, and pedants who pretend to literary attainments, frequently make a show of their learning by speaking of siu liém 'to conceal p.96 the dressed body', and jíp liém, 'to place the dressed corpse in

\footnotetext{
${ }^{1}$ Eleococca vernucosa?
} 


\section{The religious system of China \\ vol. I}

the coffin' ; but these expressions, which are derived from the ancient written language, are scarcely understood by the bulk of the people.

It is considered very fashionable and indicative of high life to have the lid nailed down by a graduate or, better still, by a mandarin. Notable families, who need not fear the extra expense this entails, are therefore very fond of inviting such a dignitary to come to their house for the purpose. Attired in the full regalia of his dignity, and escorted by such a retinue as his rank entitles him to, including, in the case of a mandarin, lictors, bearers of a large official fan and an umbrella of state, gong-beaters, and even soldiers, the great man, seated in a palankeen, repairs to the house of death. His arrival is the signal for the musicians to fall in as loudly as they can, and for the lictors to shout out an awe-inspiring iû o. o. o. After the mourners have received him with all the honours due to his rank, the headman of the coolies offers him an axe, of which the back is to do service as a hammer. The handle of this carpenter's tool is for this special occasion wrapped round with a piece of red cloth, lest bad influences emanating from the coffin should pass through the handle into the hand which holds it. To this cloth is fastened, in most cases, a red silken cord, to both ends of which a few coins are attached.

But this is no work for soft and noble hands, nor is it consistent with the dignity of a great man to grasp firmly such a vulgar object as an axe. He merely touches the end of the handle gently with his thin, long-nailed fingers, while the headman lightly strikes each of the nails once or twice on the head ; then he draws back his hand, leaving the work of driving in the nails to be done by the headman alone. The important functions of the grandee are herewith ended. The family may now freely rejoice in the happy prospect that the male issue, represented by the nails, shall attain to high official dignities : so powerful, indeed, is the influence emitted by a graduate or office-bearer. It is scarcely necessary to state that the coins, fastened to the axe, have for their object the making of moneyed men out of the graduates or mandarins still unborn.

All the male mourners now kneel down before the grandee and silently bow their foreheads to the ground, thus expressing their gratefulness for the invaluable service rendered them. But, in obedience p.97 to the rules of 


\section{The religious system of China \\ vol. I}

etiquette, he loudly protests against this homage by urging them to rise to their feet. Hereupon he is seen into his sedan-chair by the principal male mourners and leaves the house as he came, carrying the cloth, which was wrapped round the axe, along with him over the roof of his sedan as a protection against the pernicious influences of death, which might otherwise cling to him on his way home.

The above expedient to insure the birth of men of official position in the family is denoted by the term tiém pó, 'to gently tap with the axe'. As a matter of course, the tiém pó koan or 'officer who taps with the axe' must receive compensation for his trouble : in fact, in China nobody does anything for nothing. So, the family afterwards send him a roll of dollars or a parcel of broken silver, with a couple of gilt flowers, a piece of red silk and occasionally other presents besides. In many cases, one of the mourners repairs to the dwelling of the grandee, to offer these presents in person. It must still be noted that families which are not wealthy or fashionable enough to call in the aid of a mandarin or a graduate, content themselves with an old man, thus ensuring at least longevity for their offspring, which, as our readers know, is a blessing no Chinaman despises.

After the lid has been properly secured on the coffin, the coolies immediately set to work to take down the water-bed. The boards and trestles, the pillow for the head, the sleeping mat, the cloth that served to transfer the corpse into the coffin - all these things they take for themselves as a lawful emolument appertaining to their profession. If no coolies are employed, the family fling everything into the street, taking care previously to break one of the boards in twain. The lamp or candle which was burning on the water-bed (see page 21) goes the same way; the crockery used for the dead man's food and medicine during his illness, his tobacco-pipes and pouches, his teacups, implements for smoking opium and, in general, all such articles of small value as he was wont to use regularly, follow either immediately, or shortly after. Everything worth picking up falls an instant prey to beggars. It need not be stated that we have here a repetition of the custom mentioned on page 69 of doing away with the clothes in which the last breath has been drawn, and that it is founded on precisely the same principles. 


\section{The religious system of China \\ vol. I}

p.98 The next work for the coolies to do is to transfer the coffin to the spot whence the water-bed has been removed. There they arrange it on a couple of trestles purchased or borrowed from the coffin maker, taking care that the corpse be placed in the same direction in which it was stretched on the waterbed. This done they receive their wages and leave the house, taking their rafter, ropes and other implements with them. In the meantime, the paper sedan-chair which was standing outside the door (page 28) has, together with its bearers and a certain quantity of mock money, been committed to the flames and so sent to Hades, to be henceforth used there by the soul as a comfortable means of conveyance.

While the coffin is being arranged in its place, all the mourners wail and cry bitterly and do not put a stop to their lamentations until the white cloth, which was hanging in front of the water-bed (page 4) and has been removed during the coffining, is re-adjusted on the spot. This screening the coffin from view is consider a matter of importance, as it represents a custom of antiquity. Ch.12 of the Li ki (I. 19) says :

« To have a curtain before a coffin stored away for burial is not a custom of antiquity. It originated with King Kiang's bewailing her husband Muh Poh.

This Muh Poh was a contemporary of Confucius and a minister of the state of Lu, in which the sage was born.

Just in front of the curtain comes the table bearing the hûn péh. The incense-burner is placed before this soul-tablet and flanked by a pair of candle-sticks with burning tapers ; and a piece of white cloth is suspended in front of the table between the legs, down to the floor. As soon as everything is properly arranged, the mourners place themselves in two groups in front of the table, the males having the women on their right, and all wailingly make obeisance to the spirit. A large bowl of cooked rice is now placed upon the lid of the coffin. Incense-sticks are stuck into this food, that it may not only soothe the palate of the spirit, but also gratify its nostrils. Moreover, twice as many burning candles as there are sons of the dead are planted therein, as also a number of chop-sticks, usually a full set of twenty, but often many more. This is an excellent expedient to insure the family regular 


\section{The religious system of China}

vol. I

reduplications of its members, who are represented by the ${ }_{\text {p.99 }}$ candles, and to cause great numbers of dining instruments to be required by them at every meal ; for, it is an established doctrine that the ancestors are in the habit of gratefully returning to their offspring whatever they receive from it in the shape of sacrifices. By and by the mourners retire, each taking leave of the dead by bowing his forehead to the floor.

We are here face to face with a remarkable custom of antiquity. In the first chapter of the third part of this Book it will be shown from a complete translation of the principal information which the $I$ li and $L i ~ K i$ afford on the subject, that, during the Cheu dynasty, encoffined bodies of grandees and office-bearers used to be stored away for a considerable time inside the dwelling, under the western wall of the hall, where they were screened from view by means of a structure of timber plastered over with clay. Between this timber and the coffin the survivors placed baskets with scorched grain and dried fish and meat, which would keep a long time, obviously a continuation of the same process of feeding the corpse which we have had occasion to remark upon already a couple of times (pages 29 and 82). That the rice which the modern Chinese place upon the coffin is indeed a shadowing of that scorched and dried food of antiquity, is confirmed by the fact that people know it by no other name except jíp-bók bê or jíp-bók png, 'rice which is put inside the wood'.

Before concluding this chapter we have to speak of a few curious ideas and practices connected with the coffining.

In China, almanacs circulate largely amongst all classes of the people. Copies of cheap editions may be had for a few coppers at every native bookshop or bookstall. As they carefully point out which days in the course of the year are fit or unfit for proceedings and enterprises of importance, such as building or repairing houses, starting on a journey, making tombs, marrying, burying, and the like, no book can be compared to an almanac for its general usefulness. Indeed, whosoever strictly follows its instructions will always be happy and rich, while the man who disregards the same will surely fall a prey to all sorts of disaster. 


\section{The religious system of China}

vol. I

Now, the popular almanac which chiefly wields sway in Amoy and the surrounding country, regularly stigmatizes a certain number of days as tîngsng jit : 'days of reduplication of death', p.100 because encoffining or burying a dead person on such a day will entail another loss in the family shortly afterwards. Under the heading: 'Things to be avoided with regard to coffining', the book contains the following notice :

« And when, in a case of death, you have no day fit for coffining the corpse, you should lay the reduplication of the loss under restraint. Make a small envelope for this purpose, put in a piece of yellow writing paper on which four characters prescribed for the current month have been written in vermilion ink, depose it under the coffin during all the time the burial is postponed, and upon the coffin on the day of interment, and have it buried along with the coffin; if the reduplication of the case of death is in this way laid under restraint, good luck will be the result. The prescriptions for averting the calamity are as follows. In the $1^{\text {st }}, 3^{\text {rd }}, 6^{\text {th }}, 9^{\text {th }}$ and $12^{\text {th }}$ month of the year, write the four characters [abcd] and put them into the envelope; in the 2nd month write [aecf] ; in the 4th [agch]; in the 5th [aicj]; in the $7^{\text {th }}$ [akcl]; in the $8^{\text {th }}$ [amcn]; in the $10^{\text {th }}$ [aocp] ; and in the $11^{\text {th }}$ [aqrs] and the calamity shall be totally averted.

Such is the wise doctrine preached by the almanac; but people have, besides, a good method of their own in dealing with the ting-sng days. They quickly catch a big cockroach, a bedbug or any other domestic insect, which are never sought for in vain in a Chinese house, and shutting it in a little box at the moment the coffin is closed they place the box underneath the coffin and, on the day of burial, along with it in the tomb. The insect is made to act as, what people call, a thoè sin or 'substituting body', that is to say, it takes the place of the person who would p.101 otherwise have been dragged along to the grave by the influence of the ill-omened day; now this day, having obtained its full due in this way, can no more do any harm.

Another means, still more simple, of averting the influences of a tîng-sng day, is to defer the closing of the coffin till after sunset, as each day is then considered to lose a great deal of its power. The most practical way of dealing 


\section{The religious system of China}

vol. I

with it is, however, to systematically avoid looking into the almanac at all ; but it must be confessed that only very few persons venture to try the efficacy of such a dangerous ostrich-like policy.

In conclusion, it remains to be mentioned that many families in Amoy carefully wait for the flood-tide to then encoffin their dead. This custom prevails also at Ningpo, as may be seen from the 'Records of the General Conference of the Protestant Missionaries of China, held at Shanghai in 1877' (page 404). It would lead us too far from our present scope to explain here the reasons for this usage. They will be fully explained in ch. XII of the third part of this Book, where we shall review the fung shui or 'wind and water system', which purports to bring the good influences of the climate and the waters of the Universe over the tombs. It is interesting to see, many people in Amoy render themselves independent of the flood by placing in the hall a couple of jars or buckets filled with seawater taken at the last high tide; they can then shut the coffin at any moment they choose, being convinced that the influences of the high tide over the dead and his offspring are likewise perfectly insured by this proceeding. 


\section{The religious system of China}

vol. I

\section{CHAPTER VI}

\section{The interval between coffining and burial}

p.102 The lowest classes at Amoy generally bury their dead on the same day of the decease, or on the day following, especially in summer, as these poor people are unable to procure coffins substantial enough to prevent the smell from escaping when decay sets in. The great majority of the common people and even of the middle class usually defer their burials until what they call the third day, that is, the second day after that on which the decease has taken place, the intermediate day then being, as a rule, devoted to the dressing and coffining.

In such cases, the family are, of course, during the whole day of coffining busily engaged in preparing everything for the burial. The male mourners or some of their near kinsmen or intimate friends go to the mountains to look out for a proper grave-site, on which excursion they are in most instances accompanied by a member of a certain class of persons, who make it their special vocation to select graves which are situated so perfectly under the beneficial influences of heaven and earth, that the dead who sleep therein cannot but send forth all sorts of blessing over their offspring. We shall many times have to deal with these professors of geomancy, but they will receive our special attention in ch. XII of the third part of this Book.

Families who can afford to buy good coffins sufficiently strong to prevent all smell, almost always prefer keeping their dead at home for a few days longer. A so-called hiong tsòng or 'hasty burial' on the first or second day is, in fact, considered very disreputable, because, anciently, all persons of rank und position were interred after a considerable lapse of time, and good manners and high life demand the closest possible imitation of antiquity. But there are other reasons : - people who have money enough to buy a firstrate grave, so favourably situated that the amount of blessings expected to

arise therefrom shall be exceedingly large and extend over the p.103 issue of every son, are not disposed to make a hasty choice. Preferring to act 


\section{The religious system of China}

vol. I

prudently and carefully, they take their time about it, consulting sometimes more than one professor of geomancy.

The first seven days, including that on which the demise has taken place, are generally deemed to be lucky for the burial, especially the odd ones. But when they have elapsed, it becomes requisite to apply to a day-professor (see p. 47), and to have selected by this man not only an auspicious day, but also a lucky hour for taking the coffin from its place in the house, and another hour for lowering it into the grave. If such care is not taken, there is great danger of spoiling the future luck of at least same members of the family, if not of all.

The theories which underlie the calculations of the professors are easily explained. As we had occasion to remark on page 44, the Chinese divide time into cycles. The principal amongst there is a combination of two cycles numbering respectively ten and twelve characters, arranged in the following order :

kiah yih ping ting wu ki keng sin jen kwei ; kiah yih ping ting, etc.

tszĕ ch'eu yin man ch'en szĕ wu wei shen yiu suh hai ; tszĕ ch'eu, etc.

The reader will perceive without difficulty that, after six rotations of the upper and five rotations of the lower cycle, a full cycle of sixty biliteral terms is formed. This has been used at least since the beginning of the Christian era, to count in a perpetual rotation the years, months and days, thus denominating each by a binomium of characters. The cycle of twelve, or the so-called 'twelve branches' is also applied to the horary periods of the day ${ }^{1}$, the symbol tszĕ corresponding to the period from $11 \mathrm{p}$. m. to $1 \mathrm{a}$. m., ch'eu from 1 to 3 a. m., and so on. Consequently, every Chinaman has a horoscope of seven characters which indicate the year, month, day and hour of his birth, and these are firmly believed to determine his fate for ever. It is accordingly of the utmost consequence to avoid any risk of having bad influences exerted upon them by performing arts of importance in years, months, days and hours denoted by other cyclical names. The question then is, which cyclical terms work badly upon each other, and to what extent; and China fortunately p.104 possesses almanacs which solve this riddle. Indeed, on one 


\section{The religious system of China}

vol. I

of the first pages of those books one is sure to find the twenty-two symbols of the two cycles, strangely mixed up together and arranged in a circle which passes for a production of deep wisdom and ingenious calculation, though nobody can tell us on what principle it is based; diametrical lines passing through the circle enable any one to see which symbols are situated opposite or nearly opposite to each other and in consequence thereof destroy each other's influence.

Now, no transaction of importance can by any means bring good luck to the person who performs it or acts a leading part in it, if it is performed on a day or hour the cyclical characters of which stand, in the said circle, opposite to characters occurring in the horoscope of that person. In such a case, the influences of the day and hour cannot fail to do harm to the man, and the man in his turn must either prevent the enterprise from succeeding at all, or, at any rate, neutralize a great deal of the good results expected from it. In the case of a burial, this principal rule of chronomancy denotes that his horoscope will for ever prevent the dead from becoming happy, and the tomb from emitting blessings over the offspring. Perfection is reached when the calculations are applied to years and months also. But then, and especially when more than one person have to take part in the undertaking, the choice is so greatly reduced as to render it almost impossible for the day-professor to arrive at any decision.

As the law of custom requires all the principal relatives of the dead to attend the burial ceremonies and to follow the body to the grave, the selection of a day and hours for such an occasion is, in general, a very difficult problem. The day-professor consulted to arrange the matter is scarcely ever able to find dates agreeing with so many horoscopes unless he be allowed to exclude some of the more distant relatives from attending all or part of the ceremonies. If he be a clever man who desires to do his work well, he also uses as factors in his calculations the horoscope of the dead and the situation of the grave in regard to the points of the compass, thus complicating the matter, but insuring better results. Powerful amulets, capable of regulating the influences of dates and hours either when affixed

1 The so-called ch'en or shi. 


\section{The religious system of China}

vol. I

over the grave or in the house, are then requisite to counterpoise this increase of difficulties. They mostly consist of small strips of yellow paper, bearing inscriptions such as the following: "The duly invested prince who levels the p.105 influences of the year has arrived here"; "The mysterious Virgins of the nine Celestial Spheres are here present with imperial orders from Heaven to subdue unlucky influences" ; and so forth.

When the day-professor has at last delivered up his conclusions, neatly written out on a folded sheet of red paper, as also the amulets required, it not seldom occurs that the family have them verified by one of his colleagues. Our readers will not be astonished to hear, that in most cases all the calculations are then found to be totally wrong, and that the wise man who has discovered this is entrusted with the making of new ones; more expense is thus incurred, and a fresh delay of the burial entailed. To evade such inconveniences, most people at once decide on a burial within the first seven days. And if compelled by circumstances to extend this period, they evade at least the necessity of selecting a lucky hour for carrying the corpse out for burial by moving the coffin a few inches from its place at the end of every seventh day ; in this way the lucky period is fictiously prolonged for the same length of time over and over again, as often as the family think fit. Indeed, the bad influences resulting from carrying a coffin out are chiefly occasioned by the so-called thó sîn or 'spirits of the earth', who inhabit the soil and all things that are in close contact with it ; they come to perfect rest in every object which remains unshaken for seven days, and are naturally roused to anger if then disturbed in their sweet repose. A special dissertation on these spirits will be found in the Second Book of this work.

It has been stated already on page 102 that families living in easy circumstances are generally bent on securing burial sites for their dead whereupon the good influences of nature concentrate as fully as possible, and that they consult to this end even more than one geomancer. Such choice places being extremely scarce and difficult to find, the instances are not rare in which encoffined bodies are kept at home for weeks and months, nay for years. Even in the event of the grave having been selected during the life of the deceased, the burial may be impossible because of the almanac. For, each annual edition of this useful book declares in which points of the compass the 


\section{The religious system of China}

vol. I

lucky direction lies for building, burying, etc. During p.106 the current year ; and if it says for instance: Great advantage lies in the line from east to west, and no luck is in the north, the family is compelled to postpone the interment till the next year if the tomb happens to have been placed, in accordance with the profound calculations of the geomancers, in another line, or if it faces the north. Other circumstances which may occasion delay of burial, will be summed up in the third part of this Book, ch. 12.

Keeping a body unburied for a considerable time is called khng koan, 'to conceal or store away a coffin', or thîng koan, 'to detain a coffin'. It is, of course, a matter of necessity in such cases to have the cracks and fissures, and especially the seam where the case and the lid join, hermetically caulked. This is done by means of the mixture of chunam and oil, mentioned already on page 95. The seams, sometimes even the whole coffin, are pasted over with linen, and finally everything is varnished black, or, in case of a mandarin of rank red. In process of time, the varnishing is repeated as many times as the family think desirable or necessary.

And in order to protect the coffin still better against dust and moisture, it is generally covered with sheets of oiled paper, over which comes a white pall, especially if the family tear the sun's rays or moonlight will find their way to the coffin and perhaps change the corpse in a so-called kiang si or kiong si, a corpse which does not decay, a horrible and ferocious spectre fond of catching and killing passers-by, more malicious than others because, having the body at its service, it possesses more strength and vigour than other disembodied ghosts.

Such kiang si are obviously parallels of the living corpses styled vampires, which during the preceding century excited the whole of Europe, and were believed to leave their graves to prey upon the blood of the living. In China a vampire generally breaks out of its coffin during the night, as the powers of evil spectres are paralysed by daylight. It commonly kills its prey by sucking the blood out of the body, a proceeding which it completes in a few seconds. Its body is said to be covered all over with long white hair, and its nails are exceedingly long, which reminds us of a belief, also prevalent amongst Europeans, that the hair and nails continue to grow after death. For the rest, 


\section{The religious system of China}

vol. I

the description answers p.107 pretty well to that of spectres in general. And that the rays of the sun or moon favour the hideous metamorphosis may be a natural consequence of the conception that light, fire, warmth, Yang in short, are identified with life, as we had occasion to demonstrate on page 22 . People say, that the only way to render a kiang si harmless is either to destroy everything, coffin and all, by fire, or to take the corpse out and fry it in a big iron pan; but we have never heard of such an expedient being actually resorted to. In our essay on spectres in the Second Book we shall deal with the vampires at length.

\section{Ceremonial purification of the house.}

If the family know that the burial will have to be postponed longer than a few days, one of their first cares is to have the nefarious influences, that stick to the dwelling and its inmates in consequence of the decease, ceremoniously washed away by a member of a certain class of priests known in Amoy by the name of sai kong. Many of the functions of the Taoist clergymen of former ages, who now well-nigh belong to history in the province of Fuhkien, have devolved upon these men, who have consequently been generally styled Taoist priests in European works on China. But, as will be shown in a special dissertation in our second Book, it is questionable whether their history, which may be traced to the oldest pages of Chinese literature, fully entitles them to bear that name. Therefore we shall, for the sake of accuracy, henceforth denote them by the native term sai kong.

As soon as the priest has arrived, the family place a few cups of tea, a couple of plates with confections, and some burning candles and incensesticks on the table in front of the domestic altar, which, as the reader knows, has been standing in a side apartment since the demise. The articles required for the purification proper, to wit a small round pot of water and a bowl with a mixture of salt and uncooked rice, are also arranged on the altar, because this is believed to have remained exempt from the influence of death and can therefore not deprive the articles of their purity before they are used. When everything is ready, the priest, in his sacerdotal robe and cap, takes up a position in front of the altar and, tolling his hand-bell, addresses p.108 certain divinities, chantingly inviting them to descend, that the family may perform 


\section{The religious system of China}

vol. I

the purification under their propitious auspices. This done, he pronounces some incantations over the water to drive the bad influences out of it, a performance called thik tsuí, 'to give orders to the water', and then he purifies the liquid thoroughly by kindling one or two small charms of yellow paper and dropping the ashes into it. The salt and rice are then similarly purified by exorcising sentences. During these preliminaries one of the members of the family burns paper money, to enrich the deities invoked.

The priest now starts on a slow and dignified walk through the room and up and down the hall, continuously tolling his handbell. A child belonging to the house carries the exorcised water behind him. With a small leaved twig he sprinkles the liquid over the floor, the walls, the coffin, the mourners, and the relatives who have attended at the dressing and coffining and have not yet gone home, as they must first undergo the cleansing process ; all the while he drones conjurations and magic phrases of this tenor: Thien bû khī, tē bû khī, im iông bû khī, pik bû kìm khī, "Sky, earth, Yin and Yang, become devoid of dreaded influences ? let there be no taboo influences in anything at all !". For the coffin a special incantation of peculiar vigour is pronounced: Thienièm kui thien, tē-ièm kui tē, jîn-hoà tiông sing, kuí-hoà biét hîng; it soah ch'ing, jī soah tsīng, sam soah sng-soah soé khi ch'ing-tsing, "Detested influences proceeding from the sky, return to the sky! abhorred influences from the earth, go back to the earth ! May your existence be prolonged, ye elements out of which human beings are created, and ye elements which produce evil spirits, may your shapes be destroyed! First sprinkling, do purify! second sprinkling, do cleanse! third sprinkling, wash away the evil influences of death, cleanse and purify !"

After this purging process has been applied to all the apartments of the house, the mixture of salt and rice is disposed of by bits in the same way as the water. Good care, however, is taken that nothing falls on the coffin or any of the bystanders, lest fatal p.109 consequences should ensue. This part of the ceremonies is called siak iêm bí or iā iêm bí, 'dashing or strewing salt and rite'. These two articles of food, when mixed together, are considered to be a mighty weapon against invisible spirits, which are believed, all over China, to be the occasioners of every mishap and calamity, entirely frightening them away to distances whence they are perfectly harmless. 


\section{The religious system of China \\ vol. I}

It is quite natural that the spot where the water-bed has been standing and which is now occupied by the coffin, must undergo an extra purgation on this occasion. For this purpose the priest there affixes to the wall a paper charm of the same description as that wherewith he has prepared the water. Such amulets are not the products of any fixed rule : almost every priest possesses special compositions of his own. The one represented in fig. 9 bears the characters water, divine, clean, and pure, making the phrase : purification by the gods by means of water.

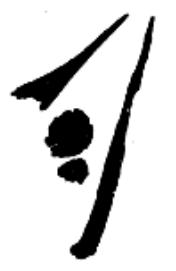

The cleansing finished, the priest returns to the altar, to express his thanks to the gods for having been so kind as to preside at the ceremony and to bid them to go where they like, as everything is now over. Having thus 'dismissed or taken leave of the gods', sî sinn, as this rite is called, he receives in payment for his services a parcel of red paper containing a hundred copper coins, takes off his robe and cap,

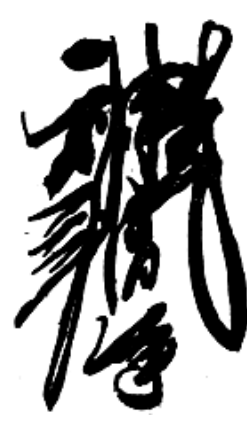
and goes his way.

Fig. 9. Amulet for Purification.

The exorcism described is generally called soé tsing, 'to wash clean'. As the remainder of the water passes for a powerful preservative against shortsightedness, the mourners and attending friends dip their fingers in it and rub their eyes with it ; some also sprinkle it over the children and babies. And if any one who was present at the preparation of the body for the grave has been obliged to leave before the arrival of the priest, p.110 a small tea-cup full of the water is sent to his house, that he also may take advantage of its useful properties; copies of the charms used by the priest, however, are occasionally sent instead, to enable the family to prepare for themselves such salutary water. Not a drop of the water is ever carelessly thrown away, because the respect for written characters is so great that ashes produced by the combustion of lettered paper may not be desecrated by being trodden on or defiled in any way.

To better understand the principles underlying the purification above described, it will be useful to consult what has been laid on p. 40 sqq. regarding the bad influences created by cases of death, and especially to bear 


\section{The religious system of China \\ vol. I}

in mind the fundamental ideas on the composition of the human soul, briefly set forth on p. 94. The incantation pronounced by the priest shows that the ceremony has for its object to disarm what he calls the kúi hoà, 'elements which produce evil spirits', to wit the kwei or such parts of the soul as are composed of Yin matter. On the other hand, he tries to redouble the vigour of the opposite part of the soul composed of Yang matter, the Yang being, as the reader knows from p. 22, the source of everything which is good and blissful and, moreover, the origin of life in general : - "ye elements, says he, which give life to human beings, have your existence prolonged". This division of the soul into an evil part or kwei and a good part or shĕn will be discussed at length in the last part of the Second Book.

\section{Sending return presents and mourning cards.}

As the Chinese rules of etiquette strictly require all favours and gifts to be returned in a manner proportionate to their value, it is incumbent on the family to present to all those who have condoled with them and given paper money to the dead (p. 30 seq.) articles to serve the same purpose as this paper, viz. as a sacrifice to their family manes. Incense-sticks, candles, mock money, sweetmeats, red cakes of flour, and other edibles form the principal part among these presents. There is also amongst the same a mixture of hemp-seeds, peas, wheat, millet and pady, as these so-called 'five cereals' ngó kok insure abundance of food to the family, especially when placed upon

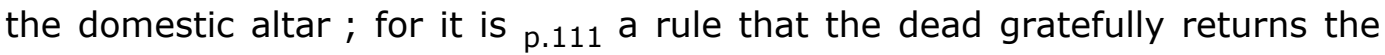
gifts offered to its soul as well as those placed with its body in the tomb (comp. p. 57). Some families endeavour to promote the realization of the object for which the cereals are sent them by sowing them in their housegardens or, in flower pots, in their court-yards or on the roofs of their dwellings. The red cakes, which are the âng in mentioned on page 76, are also ministrant to good luck, because red, dispelling evil influences, is the colour of happiness, and the round shape is symbolical of perfection, in this special case of the perfection of the luck represented by the colour of the cakes.

If there be no postponement of the burial, the preparations in connection with the rites thereof take up all the time and energy of the family, so that 


\section{The religious system of China \\ vol. I}

this tap tsoá or tap koan-thâo tsoá, 'making returns for the paper' or 'for the coffin-paper', must necessarily be delayed till after the interment. The same holds good for the cleansing ceremony above described, as also for the distribution of printed announcements of the decease, which families in easy circumstances are in the habit of sending to relations, friends and acquaintances.

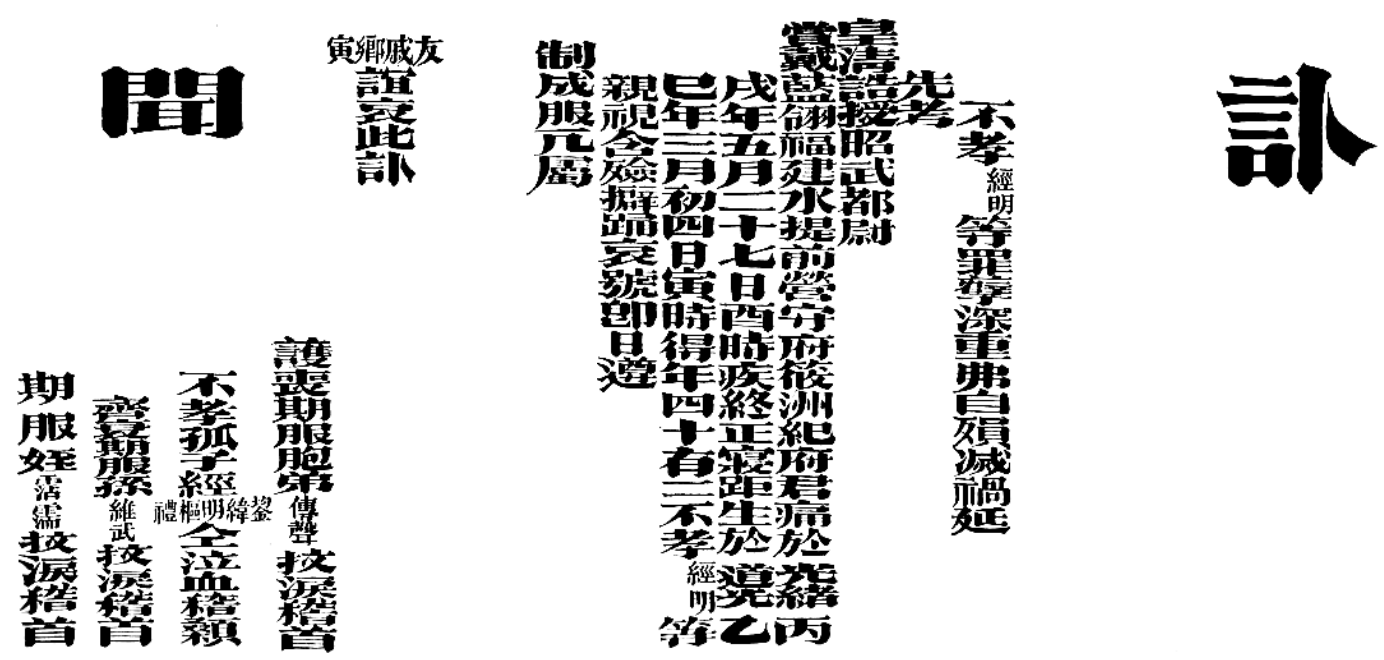

PI. VII. ['Card with the news of death'].

Such hù im thiep or 'cards with the news of death' (see PI. VII) are of brown, yellow or white paper. They are from two to there decimetres broad and in many instances as long as one meter, and they are folded lengthwise to look like an unbound native book of double leaves; the page which comes outside, is inscribed with the character hù, 'obituary notice'. The wording is much the same for them all. Here is a translation.

The crimes and sins of the unfilial.... (name of the eldest son) and his fellow mourners were deep and heavy, but instead of killing and destroying the perpetrators thereof, the disaster engendered by them has reached our deceased father" (Here follows his name and an enumeration of his official rank and titles, including those purchased and the dignities held in former times, which in the course of years may have been replaced by higher ones, the whole official or nominally official career being in this way passed in review). Alas, in the year..., the month..., on the day.... and the hour..., his life was cut short by disease in the principal back-chamber. He was born in the year..., the 


\section{The religious system of China \\ vol. I}

month..., on the day... and the hour..., and thus reached the age of ... p.112 years. The unfilial.... (eldest son) and his fellow mourners have personally attended to the placing of articles in the mouth of the dead and to the dressing of the body. They have beaten their breasts and stamped their feet, wailed and cried, and, in obedience to the rescripts, they have assumed the full mourning dress on the next day. Wailingly they herewith give notice thereof to those who are related to them as friends, as family-members, as fellow villagers and as colleagues.

The patron of the funeral rites ..., younger brother to the deceased by the same mother, who wears the one year's mourning, wipes away his tears and bows his head to the ground.

The unfilial male orphans... weep tears of blood in concert, and bow their heads to the floor.

The grandsons and great-grandson ..., the brothers ..., the brothers' sons ..., the brothers' grandsons ... and so forth ... wearing mourning for one year, nine months or five months, wipe away their tears and bow their heads to the ground.

The signing of the card with so many names serves to shed a lustre on the dead, it being in China the height of fashion to possess a numerous male issue. The so-called 'patron of the funeral rites', hō song, whose name figures first of all, has to see that the rites are properly performed in accordance with the means of the family and the rank of the dead. He is always a man of higher position in the hierarchy of the family than the sons whose actions he has to control, otherwise he would have no authority over the latter. Women never sign the card. All their duties lie in-doors, and morality forbids their mixing with the outside world.

The cards are printed with either black or blue ink. But the characters which in the description of the titles of the dead relate to an emperor, as also the words friends, family members, fellow villagers and colleagues, must for the sake of courtesy be red, because this is the colour of felicity. The word rescripts is red too, because it refers to the Son of Heaven, the rules of mourning being codified in the imperial laws and statutes. 


\section{The religious system of China}

vol. I

Obituary notices are distributed in envelopes of a corresponding colour. Over the middle of the frontside of the envelope runs, from p.113 top to bottom, a strip of blue paper over which a somewhat narrower strip of red is pasted, bearing the address ; for it would be very bad style to write the name etc. of other people on an ill-omened blue mourning colour. In case of a person of celebrity or distinction, a smaller envelope is often enclosed in the first ; it contains a printed necrology in epistolary form, laying special stress upon the great things the dead man has done in his life and setting forth the great services he has rendered to his family, his village and, eventually, to his country. The names of the sons alone are found at the foot of this document.

When there is no delay in burial, obituary cards are as a rule not distributed until the interment is over. And in case the relations have already fixed the dates on which they will celebrate the great requiem mass to which we have already alluded on page 83, the card announces, at the end, on which days during that mass the family will receive the visits of friends and acquaintances who may desire to call and offer sacrificial articles to the dead.

Portraits of the deceased.

Among the well-to-do citizens of Amoy it is a general custom to procure polychromic full length pictures of their deceased father and mother (see PI. VIII), to keep them in the hall of the house, hung against the wall. In some few cases such a portrait is made during the life-time of the person whom it represents ; mostly, however, the painter is not called in until after death to take the sketch, which he can complete at leisure in his own workshop. If he can manage to have it ready before the burial, the family hang it on the wall just over the coffin, the idea being that it may serve the same purpose as the wooden soul-tablet, viz. as a seat for the spirit of the dead, an alter ego doing duty for the body now shut up in the coffin. With a view to this object, the family are always very anxious to obtain a good portrait. Hence the painter is in many instances compelled to do the face over and over again, until he succeeds in convincing them that the likeness is perfect.

As the portrait is intended to enable the deceased to live on among his descendants even though he has been translated from this life, it is called a 


\section{The religious system of China}

vol. I

taī siū or 'arge longevity'. It either represents the dead man in official robes and cap, or, if he never took or bought a degree, in the ceremonial attire tho p'aò p.114 (page 49 seq.); a woman is generally represented in the official or bridal attire described on p. 53 sqq. The image is always in a very stiff, sitting posture, which the Chinese consider the height of fashion and distinction. It always shows the full face, never the profile. The dimensions average commonly between seven and eight decimetres, but in order to conciliate the Chinese ideas of esthetics, it is pasted on a much larger scroll of white paper which, like a geographical map, is fastened to a wooden roller above and below.

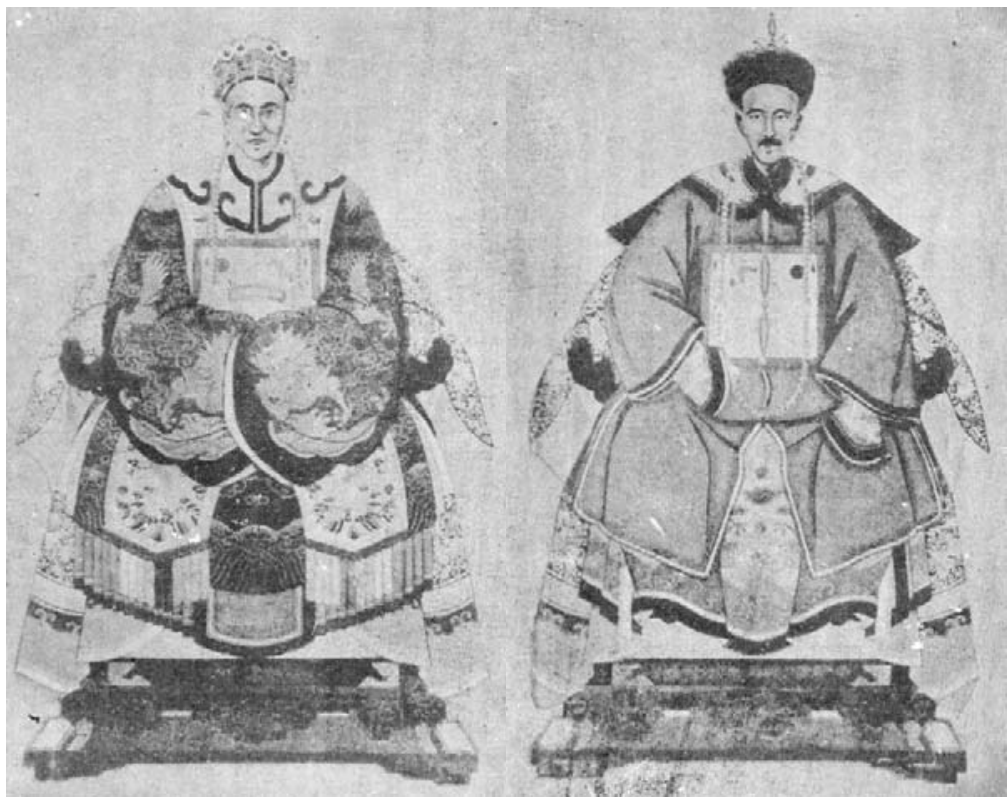

PI. VIII. Portraits of a deceased Lady and Gentleman.

In the next chapter it will be seen that the taī siū of a dead man is carried in his funeral procession; after the burial it is hung up against one of the side walls of the hall, either to remain there, or, as in a few cases, to be transferred to the temple dedicated to the worship of the ancestors of the clan in common. From this it would appear that it bears some resemblance to the imagines majorum of the ancient Romans. Indeed, it is well known that with this nation the effigies of the distinguished dead were made to escort the body to its last resting place and then preserved around the atrium, where stood the altar with the penates and lares. 


\section{The religious system of China}

vol. I

Many families in easy circumstances have in the halls of their houses also a so-called siáo íng or 'miniature portrait'. This is a large picture in water colours, bearing a small sized image of the dead man in a nice every day attire, and of his wife, children and, occasionally, other members of the family, some doing nothing, others performing household work, studying, playing, flying kites, and so on. But such a still life only serves to keep up the remembrance of the dead; it is no artificial body for the soul, and so it stands quite apart from the taī siū.

Sacrifices, and acts of worship and salvation.

As long as the coffin is in the house, the hall is as a rule kept in the unfurnished condition to which it was reduced when the dead man breathed his last (p. 25). But the practice so closely connected with it of sleeping on mats or straw at the side of the dead is, after the coffining, generally given up. Only in very notable families, especially when the dead man is a mandarin, or one or more of his sons are office-bearers, this custom is sometimes kept up for one or two days longer under the designation of tsiú koan, 'to watch the coffin', not so much, though, out of a p.115 sense of duty, as because it was done in holy antiquity by and for noblemen and servants of the state; and a close imitation of the ancients is in China considered the most decided proof of fashion, distinction and an excellent orthodox education.

In the early morning of the day after the coffining fresh candles are lighted on the table in front of the coffin, and a dish of cakes with a cup of tea are arranged there, to refresh the spirit which resides in the hûn péh. All the mourners in their white hempen dresses then kneel around it and set up a loud and long death howl, from time to time laying their foreheads on the floor, while the chief mourner places incense-sticks in the censer as an offering to the dead. This rite may be considered as a continuation of the howling ceremony observed immediately after death (see p. 10) and, like it, to be an attempt to induce the soul to return into the corpse and call it back to life. It is denominated by the word kiò khí, 'to call to stand up'. 


\section{The religious system of China}

vol. I

After the wailing has gone on for some time, the eatables which are to serve for the breakfast of the family are arranged on the same table, as a sacrifice to the soul. A large bowl of boiled rice stands conspicuous in the midst of several dishes of viands and vegetables, the quantity and quality of which vary in accordance with the wealth of the family. A couple of chopsticks are kindly furnished to enable the spirit to bring the food to its mouth. While the prostrate mourners pour forth their melancholy concert of death dirges, the eldest son presents incense and, reverently kneeling down before the table, bows his head to the ground three times, which act is imitated by the other mourners in the order of proximity. When they have one after another retired into the side apartments and the wailing has entirely ceased, it is ascertained by means of the divining coins mentioned on page 85 whether the soul has replenished the wants of its stomach or not; and as soon as an affirmative answer is obtained some paper money is consumed to ashes, while the edibles are being removed for the use of the family.

This so-called hao png or 'presentation of food prescribed by filial conduct', is repeated in the same manner about sunset, the offerings this time being the food destined for the supper of the family. The introductory bowling ceremony is now styled kiò khùn, 'to call to turn in'.

p.116 On each of the six following days both these morning and evening rites are gone through by the mourners in a similar way, even if the dead be interred within that period. In the chapters on the worship of the soul, in our Second Book, we shall have occasion to say more about these sacrifices. We must now pass in review what the ancient books say on this head, and see what light we can obtain from the same as to their origin and meaning.

After a lengthy description of the dressing and coffining of an ordinary official, and of the way in which the coffin was stored away in the hall to await the time of burial, ch. 28 of the I li passes on to the rites of the next day, saying (l. 37 sqq.) :

«In the morning and evening they wail, not omitting to do so too on the days tszĕ and mao ${ }^{1}$. The women go to their place in the (eastern

\footnotetext{
1 Tszĕ and mao are terms in the duodenary cycle described on page 103. Ching
} 


\section{The religious system of China}

vol. I

part of the) hall, the principal amongst them standing on the south, and then they wail. The males take their station outside the (inner) gate, facing the west, and the principal among them stand on the north ; the male relatives of a different surname stand on their south side, the principal on the south, while the visitors (viz. high nobles and Great officers) stand next, the principal ones on the north. Those who stand on the east side of the (outer) gate, (viz. the feudal Rulers) face the north and have the principal among them on the west side, while those who stand in a similar position on the west side (nobles of other countries) have the principal on the east; lastly, the other persons who stand on the west side face the east, and have their chief personages standing on the north. p.117

The principal mourner having taken his station (outside the inner gate, east), this gate is opened. The women hereupon lay their hands on their hearts, but do not wail. Turning successively to the three sides, the principal mourner bows to the visitors; thereupon he turns to the right, enters the gate, and wails, while the women stamp their feet.

He now places himself at the foot of the hall, under the eastern wall of the court-yard, with his face west. The male relatives of a different surname station themselves there in the same way as they stood outside the gate; the high nobles and Great officers come to the south side of the principal mourner, and the dukes go to the east side of the gate, advancing a little in the direction of the hall. The different nobles of other realms take up a position on the west side of the gate, also advancing a little to the front. Now saluting those of equal rank, the principal mourner first bows to the visitors front other countries, then

\footnotetext{
Khang-ch'ing says, that Kieh and Cheu Wang, the last tyrants respectively of the Hia and the Shang dynasty, perished in battle, which put an end to their criminal away, the former an a mao day, the latter on a tszĕ day, and that ever since those days have been considered unfit for transactions of a felicitous character. Indeed, if we open the Tso $c h^{\prime}$ wen, we read at the head of the account of events during the $18^{\text {th }}$ year of Duke Chao, that Kwun-wu reached the height of his crimes on a yih-mao day, white the Shi king teaches that Kwun-wu perished with Kieh in the same battle (Odes of Shang 4), so that yih-mao is evidently the date or the death of Kieh. And as to Cheu Wang, the Shu king states explicitly that the renowned belle in the country of Muh, in which he fell, took place on a kiah-tszĕ day (see 'The speech at Muh'). In ch. 13 or the Li ki (I. 21) we read : "No music is made on tszĕ and mao days".
} 


\section{The religious system of China}

vol. I

from his place (in the centre of the court-yard) he makes reverences towards all the different nobles collectively.

From a careful perusal of the above extracts with the aid of the sketch of an ancient mansion given on Plate $I$, it will be seen that we have here a simple description of the manner in which the different groups were first arranged outside the gate to receive the salutations of the principal mourner by way of a silent invitation to enter, and then how they re-arranged themselves in a corresponding manner in the court-yard. The $I / i$ here suddenly stops short, but Ching Khang-ch'ing is probably right in saying :

«When all the visitors had occupied the places prescribed above, the wailing commenced, not to cease until their grief was entirely p.118 poured out.

The $I$ li then goes on to describe how the sacrificial articles, offered to the soul the day before in the back chamber, were removed and forthwith replaced by fresh ones; this last proceeding which is the prototype of the modern haò png, is told in the following words (I. 44 seq.) :

« The sacrificial articles are now set out. When the must, spirits, dried meat and pickled meat are taken up the steps, the males stamp their feet. These articles having been brought inside the chamber, they are set down in the same order as on the former occasion, but no napkins are laid over them. The men who put them down in their places then leave the chamber and station themselves to the west of the door, the principal amongst them on the west, and the torch-bearer with extinguished torch retires also. The Invoker now closes the door and precedes the others in going down by the western steps, at which moment the women stamp their feet. They then pass by the south side of the Double and proceed eastward, while the males stamp their feet.

The visitors now leave the gate, while the women stamp their feet. With bows the principal mourner sees them off. The chief male mourners now go out of the gate also, the women again stamping their feet, but they cease their lamentations and all go to their places when the mourners have left. The gate is then closed, and the 


\section{The religious system of China}

vol. I

principal mourner, having seen the visitors off with bows and made reverences to the other mourners, repairs to his shed.

That the same sacrifice was repeated in the evening is fully proved by the Li ki, which says in its $11^{\text {th }}$ chapter (I. 41) :

«The morning sacrifice is presented at sunrise, and the evening sacrifice when the sun is about to set (141).

By way of addition to the above particulars, the $I$ li has in ch. 31 (I. 34 seq.) :

«A meal of the p.119 usual food, eatables, exquisite dishes, warm water, and washing water for the head are set out, as used to be done in former days; but on the new moon, and when first fruits are offered, no eatables are presented in the lower chamber.

In other words, a sacrifice was also set out in the private apartment of the dead, and the articles necessary for his toilet were taken there to him at the same time. This passage is especially important because it reveals at once the true nature of the sacrifice, which was nothing more than a continuation of similar acts of filial devotion, which dutiful children were anciently taught to observe regularly every morning while their parents were alive. We find these acts circumscribed in ch. 39 of the Li ki (I. 6 and 13) in the following words.

«Thus equipped, (the sons and the daughters-in-law) shall go to the abode of their parents and parents-in-law. In bringing in the implements for them to wash, the younger shall reverently hold up the basin, and the elder the water, asking permission to pour out the water for washing ; and when the washing is finished, they shall hand the towel. They shall ask what things are wanted and then respectfully bring them in, with a face of pleasure to make their parents feel pleased, - thick gruel, water-gruel, spirits, must, vegetables, soup, pulse, wheat, hempseed, rice, millet, spiked millet and glutinous millet, in short, whatever they can wish. With dates, chestnuts, sirup and honey they shall sweeten these eatables; with the kin plant, the hwan plant, white elm, ordinary elm, fresh or dry, soaked in water or 


\section{The religious system of China \\ vol. I}

rendered unctuous, they shall moisten and lubricate the same ${ }^{1}$; with fat and oil they shall enrich them ; and after the parents or parents-inlaw have certainly tasted them, the young people shall withdraw...

While father and mother are both alive, at their regular meals in the morning and evening the eldest son and his wife shall encourage them to eat of everything, and what is left after all they will themselves eat (142).

p.120 The close connexion between the above precepts and the sacrifices now under notice was frankly acknowledged already in the second century of our era by Ching Khang-ch'ing, the ever famous founder of the authoritative school of criticism on the ancient classics, whom we have had occasion to introduce to our readers more than once. Commenting on the above passage of ch. 31 of the $I$ li, he says :

«Filial sons can not bear to neglect for one day their duty to serve their parents; therefore, every day they set out the articles in the lower chamber as if the deceased were still abiding with them alive.

Confucius taught :

« Serving the dead as they were served when alive, and those who have passed away as if they were still abiding amongst us, this is the summit of filial conduct (143).

Now considering that such filial conduct, or, in other terms, implicit submission and devotion to parents denominated among the Chinese by the special word hiao, has since the oldest times stood foremost in China amongst all ethics, and has been preached by all philosophers as the highest of domestic and national duties, it can by no means be a matter of surprise to find, that sufficient importance was attached to the ancient howling and sacrificial rite described above to induce even dignitaries of the highest rank and noblemen from other kingdoms to congregate and attend it in the case of an ordinary servant of the State. Neither is it unnatural that this rite has

\footnotetext{
${ }^{1}$ It is not possible to determine what these kin and hwan plants were, neither can we say which parts of the elm were used for food, as no culinary works have been bequeathed to posterity by the ancients.
} 


\section{The religious system of China}

vol. I

outlived the ravages of time and is still faithfully observed in every case of death : in fact, the sway of the doctrine of hiao is still as undisputed as ever and has not suffered the least decline. The name which the sacrifice now bears, viz. 'presentation of food prescribed by filial conduct' (see p. 115), still testifies to its origin.

Customary law, based on precepts laid down in the ancient books p.121 of rites, requires sacrifices to be offered in the hall to the soul tablet at long, regular periods after the decease. These sacrifices stand in no relation whatever to the burial ; hence they are also performed at their proper dates though the coffin be stored away in the house. They will be described in our Second Book, in the chapters which are devoted to the worship of the soul.

This is the proper place to mention the fact that the mourners, as long as the coffin is in the house, are bound by custom to offer every evening burning candles and a few incense-sticks to the soul, allowing the lights and the odoriferous matter to burn away entirely in front of the soul-tablet and the coffin. Friends and relatives, on entering the hall, will scarcely ever neglect to respectfully join their hands together and politely bow to the coffin, silently acknowledging in this way that the dead man lying inside, or his soul hovering over the spot, is still the actual chieftain of the family.

We have spoken more than once of a great requiem mass, which people usually celebrate after a case of death, in order to liberate the soul from the miseries of the Nether-world and to translate it to the Buddhist Paradise. Though this ceremony or, more correctly, this concatenation of ceremonies, may commence immediately after the coffining, we can not enter upon it here. It has indeed, under the influence of Shâkyamuni's Church, so completely taken a Buddhist shape, that we are compelled to reserve a detailed account of it for our Book on Buddhism. Families wealthy and distinguished enough to afford the luxury of storing coffins away, always set apart a whole series of days for this mass, wasting on each day much money. in order that the ceremonies may be celebrated with unusual pomp and splendour. On this account they have in most instances to wait a long time ere the condition of their cash and the state of the business of each mourner are such as to allow of the required outlay and loss of time. A provisory mass 


\section{The religious system of China \\ vol. I}

on a smaller scale then becomes requisite, it being of course, highly unfilial, nay a disgraceful infamy, to leave the soul of a father or mother without relief for any length of time; and the mourners take good care to perform as soon as possible after the coffining what duty demands.

In an apartment adjoining the hall, large coloured pictures of three images representing the Buddha, the Dharma or the Law, and the Sangha or the Church, are suspended on one of the walls, in most cases over the domestic altar which, as the reader no doubt remembers, was removed out of the hall

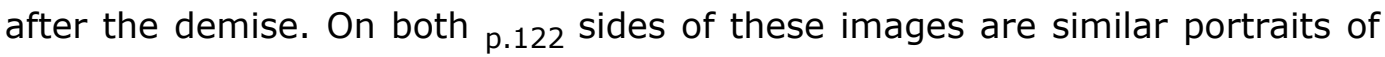
bodhisatwas, of Awalôkitêçwara and of eighteen famous apostles of the

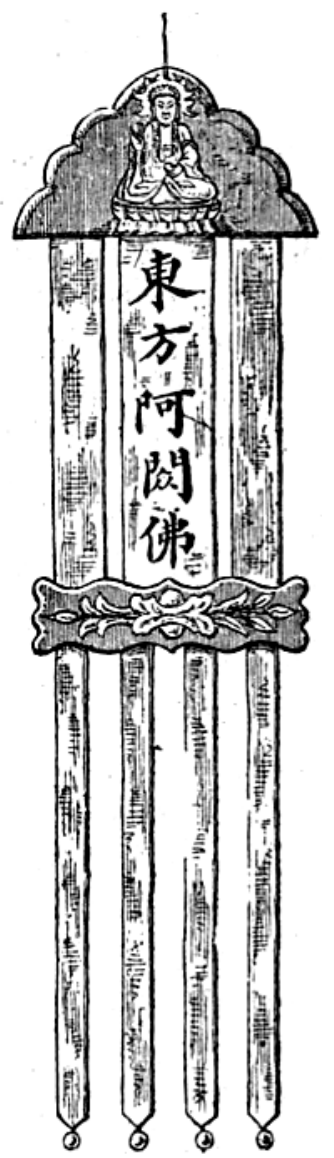
Church. Tables standing in front are spread with cakes, fruit and various eatables of a vegetable kind, but meat and fish are strictly excluded, because the Buddhist Church forbids animal food and consequently never offers this to her saints. This altar, which is called a pút toân or 'altar of buddhas', is adorned with banners (see the annexed figure) each composed of seven strips of linen, three of which are affixed between two wooden boards; the other four strips hang loosely down from the lower board and have each a small globular jingling bell at the extremity. Each of these so-called tông hoan), 'streamers or banners', bears on the topmost board, which is triangular in shape, the portrait of one of the buddhas of the six points of the Universe and, besides, the name of this being on the middlemost of the three upper strips; the strips are also of the colour which Chinese philosophy identifies with the corresponding point of the compass. So, there is an azure, a red, white, black, yellow and deep blue streamer, bearing respectively the inscriptions:

Fig. 10. Buddha Banner.

The Buddha. Akshobhya, of the East,

The Buddha more precious than any other, of the South, otherwise called Torch of the Sun and Moon,

The Buddha Amitâbha of the West, 


\section{The religious system of China \\ vol. I}

The Buddha with flaming Shoulders of the North,

The Buddha Singha of the World below, i. e. Shâkyamuni.

The Buddha of Brahma's Voice, of the Zenith. p.123

According to the Amitâbha Sûtra which is the principal authority on which the Buddhist Church in China bases her doctrine of the Western Paradise, these six buddhas each govern a part of the Universe in concert with myriads of other buddhas. They are represented on the altar because the said Sûtra is to play a most important part in the ceremonies ; indeed, it is an article in the creed of the Church that the recitation of no other sacred book can equal it in efficacy, when the object is to gain admission for a soul into Paradise. Thanks to the streamers, the spirit of each of the six mighty saints is present on the altar and may exert its beneficial influence upon the meritorious work of redemption, which is about to be performed on the spot. With regard to the host of other holy ones the same result is effected by means of square pieces of pasteboard, each inscribed with the name of a bodhisatwa or dewa, or bearing a collective expression embracing a whole class of saints. These socalled khiā sò or 'standing invocations' are arranged over the whole altar, each at a place suitable to the rank and dignity of the being or class of beings which it represents. Finally, the altar is nicely decorated with pieces of variegated embroidered silk, lamps, candlesticks, images of wood and metal, and the like, according to taste and wealth. A complete set of instruments used by Buddhist priests when reading prayers and sending up invocations and hymns, are never wanting ; and so one may also see upon or at the side of the altar, in a standing position, one or two crosiers, these objects having, as has been said on page 55, an extensive power over Hell, which has now to be conquered to obtain the delivery of the soul from its pains.

In case the house should not have a room large enough to contain such an altar, this may be erected in a neighbouring dwelling, in an apartment hired to that end by the family.

Either three or five Buddhist priests, in the case of rich people even seven, are employed by the family to perform the work of delivery. Arrayed in their Kâshâya or ceremonial dress of the highest order, they spend nearly the whole day in reciting before the altar such canonical books as are known specially to possess the power of redeeming souls from Hell and of sending 


\section{The religious system of China}

vol. I

them up to the Western Paradise. The Church in China has many productions of this kind, all of which themselves profess to be endowed with such power, p.124 but, as has been said, the Amitâbha Sûtra is the best of all. While reading, the priests keep exact time by means of the wooden globe mentioned on page 72 , on which one of them gives a gentle knock at each syllable pronounced. And when they come to rythmical parts wherewith all Buddhist canons in China are interspersed, their voices pass into a kind of choral singing, the accompaniment then, in addition to an open metal bowl also mentioned on page 72 , consisting of a few ordinary instruments, played by a small band of musicians engaged for the purpose.

Such recitations of holy scriptures are from time to time performed also in front of the coffin, at a table placed in the central part of the hall. One or more tables bearing a complete sacrificial meal with sundry sorts of dainties and cakes, stand in the immediate vicinity of the coffin all day long, and the mourners, clad in sackcloth, may be seen to advance often, especially when fresh articles are brought in from the kitchen, to offer incense and wailingly bow their heads to the ground, encouraging the soul in this way to eat and drink at pleasure. That considerable quantities of paper money are burned at intervals we need scarcely say.

The most important part of these ceremonies is a walk undertaken through the hall and the adjacent apartments, with the purpose of leading the soul into Paradise. With the children, grandchildren and other relatives in the rear, all wailing and lamenting in a loud tone of voice, the priests, after having first finished a reading of the Amitâbha Sûtra by way of introduction, march one behind the other between benches, chairs, tables, and around the coffin, winding their way through one door to another and incessantly repeating the word $O$-bî-tô, which is a corruption of the name of Amitâbha. This Buddha of the West has also the control of the Paradise, which the Church teaches as existing in that part of the Universe. His name is of a most wonderful efficacy in matters of salvation, and it is therefore not to be wondered at that the priests, at the critical moment when they have to bring the redemption of the soul to a conclusion, simultaneously repeat it thousands of times, thus accumulating a large amount of merit, which they transfer to the benefit of the dead. The utterance is rapid, but time is kept by 


\section{The religious system of China}

vol. I

the help of the wooden globe and a small metal bell on a long handle, each played on by one of the marching priests.

Fig. 11. Streamer harbouring the Soul.

A peculiar streamer (see Fig. 11), more than a metre long, is, during the promenade, solemnly carried on the top of a staff by the p.125 principal mourner. It is shaped like the banners of the six buddhas mentioned above, but flies from under a circular frame of bamboo splints, covered with the same material of which the strips are made, and which is of blue glossy silk amongst the well-to-do, of blue or white paper with the poor. Six ornamental tapes hang loosely down from the frame. The inscription is placed on the middlemost of the three upper strips and addressed to Amitâbha. Here is the translation of one, out of many.

« Om, May Thy nimbus call to Thee the real soul of the deceased Wĕn-

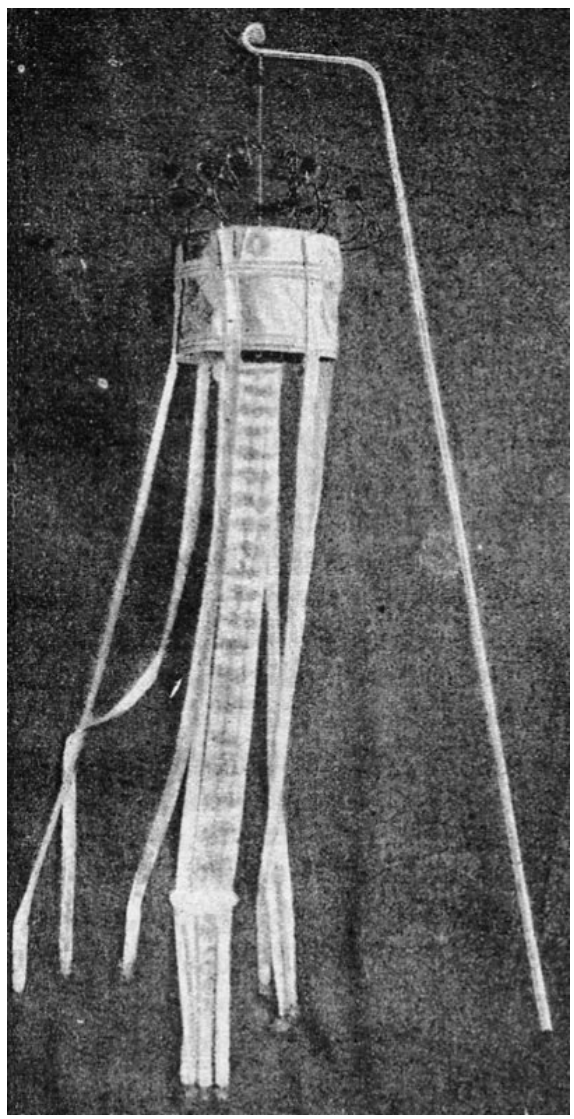
jü, the chief of the Yang family, upon whom the Imperial house of Ts'ing has conferred the honorary title of the sixth degree and who was a graduate of this district with the dignity of Archivist of the Imperial Academy of Learning. May his soul speedily repair to the regions of the West to entrust itself to the process of transformation into an independent existence of careless diversion amidst the lotustanks; may it receive and enjoy the treasures and food (which the surviving relations sacrifice to it), being entirely p.126 extricated from the bitter wheel of transmigration. Ahum ${ }^{1}$.

On the reverse side the slip has :

1 The word Om at the head of the invocation is the first, and Ahum the last word of the well-known Buddhist formula 'Om mani padme hum'. 


\section{The religious system of China \\ vol. I}

« Buddha Amitâbha of me, sacerdotal leader of the ninth rank ${ }^{1}$, we salute Thee, who reigneth in the realm of peace, in the region of extreme delight, in the pure land of the West where the souls are received and introduced.

This hoan or 'streamer' presents one of the best illustrations of the genius of the Chinese people in inventing expedients to insure the happiness of the dead. Note that there is an ancient theory that the human soul is composed of three parts which are created by the Yang, and of seven parts produced by the Yin element. Now, the streamer is made expressly of three broad strips and seven strips, that the soul of the dead may exactly fit in and consequently not hesitate to take up its abode therein immediately. But, by so doing, it places itself forthwith under the full influence of the powerful inscription and is, thanks to the same, easily piloted into the desired Paradise. Indeed, as the streamer bears the ineffable name of Amitâbha, it exercises, when waved about, the same redeeming influence as the verbal recitation of that name thousands and thousands of times. And the streamers of the six buddhas, likewise made of seven strips, all serve a similar purpose. Therefore they are, when priests and mourners deem fit, also carried about during the procession.

Gaining admission for the soul to the Paradise of the West by these ceremonies is called tng se-hong, 'sending home to the regions of the West'. In most cases only one day is devoted to the celebration. With the rich, however, this celebration sometimes lasts three days, and then the purse of the family is severely taxed, as relations and friends usually honour the rites with their presence and have in consequence to be invited to dinner and supper. Each day is concluded with a burnt offering of a large quantity of p.127 'treasury money', in many instances connected with all the religious practices described in detail on page $78 \mathrm{sqq}$.

Storing coffins away outside the dwelling.

It is, of course, a very inconvenient matter to have to keep a coffin at home for a long time. Most Chinese are, moreover, extremely superstitious and firmly believe that, if burial is delayed for say one year or longer, the

${ }^{1}$ Apostrophe by the priest who presides at the rites. 


\section{The religious system of China}

vol. I

corpse may bring evil over the house. Indeed, even the most angelic soul would be naturally driven to madness if so long deprived of all chance of obtaining final rest in the tomb ; it might even re-unite itself with the body, change into a kiang si and kill the inmates of the house. Especially if three years are allowed to elapse, the dreaded metamorphosis will certainly take place, as most people assert.

It is consequently very common to deposit coffined bodies, for which no proper burial site has as yet been found, outside the precincts of the town. The spot selected to such an end is generally a plot of ground belonging to the family or held on lease; sometimes a corner of some field is rented on purpose for the time being. A small cottage of bricks, or of clay and lime mixed together, is erected and good care taken that it is closed on all sides, lest sun or moon peep through the openings of the walls or the roof-tiles and further the metamorphosis of the corpse into a kiang si. More generally still the coffin is covered over with a very narrow vault of masonry, or of straw, matting, bamboo and wood plastered all over with clay and lime, one or more small holes being left at the sides to allow the soul to freely wander in and out. It is very usual to make these openings in the shape of the characters [], 'male individuals', and [], 'talents', that by the influence of these symbols the dead may bless the offspring with a great number of sons, who by their talents shall arrive at high positions and thus surround the family with an aureola of glory.

Such a shed or vault goes by the name síp ts'ù, a term which may be translated by 'sepulchral house' or 'funeral vault'. The coffin is taken to it with all the rites, pomp and splendour appertaining to a funeral ; afterwards, when a burial site is found, it is carried to the grave with very little ceremony. To protect p.128 the coffin against the attacks of white ants and other destructive vermin, the mourners take good care to leave a small space between it and the ground ; they also cover it with oiled piper to prevent the paint and the wood from being spoiled by the influence of the weather. If the síp ts'ù be a cottage and thus afford the required space, a table is placed in front of the coffin with a censer and a pair of candlesticks, that the tenant of the field, or some one living in the neighbourhood and appointed by the family to look after the coffin, may offer incense-sticks and candles every day, and the 


\section{The religious system of China}

vol. I

kinsmen do this at every new moon and full moon, when they pay their usual visit to the spot.

Farmers who happen to have a small hut in their field or garden, often derive a regular income from it by keeping there in safe custody, against remunerative payment, the coffins of other people. But the well-to-do, who can afford to pay well, prefer to deposit their dead in Buddhist mountain temples, of which there are several in the environs of most towns of importance. It is, however, generally very difficult to obtain permission for this from the consistory and the priests of such an establishment, they being well aware that, if they were too liberal on the point, so many corpses would soon be accumulated within the premises, that the laymen and laywomen, who are in the habit of visiting the place to worship the gods, would refrain from coming back. So, coffins are only admitted against a very high payment. and on condition that they shall soon be taken away. The duty of daily burning candles and incense before them then devolves on the priests, who inhabit the establishment. That the dead are stored up in an obscure apartment into which no worshippers are expected to penetrate, need scarcely be said. The consistories of most mountain temples flatly refuse to take any coffins inside the precincts.

It is by no means a matter of rare occurrence that, when a coffin is about to be lowered into the grave, some individuals suddenly turn up to protest against the interment and even to forcibly prevent it, pretending that the soil is their property, or that the grave will completely spoil the auspicious situation of a tomb in the neighbourhood belonging to them. Noisy quarrels and vociferous discussions immediately ensue. The grave-diggers, coffinbearers and other men employed in the funeral train, convinced that the matter does not in the least concern them, render the mourners no assistance, but quietly stand around smoking their pipes to see what will be the end of the matter, meanwhile the auspicious p.129 hour assigned for the interment elapses, the end being that the mourners have either to take the coffin to a temple in the vicinity, or leave it on or near the spot and quickly build a síp ts'ù over it. Custom severely forbids taking a coffin homewards again, on account of the ancient principle mentioned on page 32 , that in funeral matters there should be a regular progress, no retrogressive 


\section{The religious system of China}

vol. I

movement ; moreover Confucius himself has said : "An encoffined body may not be taken back". Many a síp ts'ù owes its origin to events of the above kind, disputes about landed property and immovable goods in general being perhaps nowhere in the world more common than in the badly administered Empire of the Midst. Many also are erected because it is usual for every family, on discovering that an interred coffin has been attacked by white ants or suffers front the ground-water, to exhume it without delay and to leave it on or near the spot until a better grave has been found and purchased.

Temporarily confiding a corpse to other people for safe keeping, which the inhabitants of Amoy call kià koan, 'intrusting others with a coffin', is also commonly recurred to when the dead man's family seat is in another part of the empire, and his kindred expert they may sooner or later be able to convey his mortal remains thither. Sending the dead to their ancestral home, there to be buried, is, indeed, very common with the well-to-do, as will be demonstrated in the tenth chapter of the third part of this Book.

The reasons for leaving coffins for a time unburied being manifold, it is very natural that in many parts of China, especially in such where burial ground is scarce, the soil is as it were studded with corpses awaiting interment. In my own journeys through the empire scarcely a day passed on which I did not see several. In the environs of Kung-ch'wen, a little town on the Min between the cities of Yung-ngan-hien and Yen-phing-fu, I found them in the fields in such large numbers, that I almost felt compelled to conclude no interments took place in this part of the country at all. By scores and scores they were piled up in small huts consisting of three walls with a roof, having neither wall nor door in front. Just outside the large village of p.130 Hing thien, situated in the north-west of Fuhkien province, on the highroad between Kien-yang-hien and Ch'ung ngan-hien, dozens of well-made substantial coffins merely covered with a loose piece of old matting studded the open ground; at the head of each was pasted a sheet of red paper bearing the character [], 'long life', to prevent them from emanating lifedestroying influences and so operating destructively upon the living beings thereabout. A similar spectacle presented itself in the environs of Ch'ungngan-hien, and in the neighbouring mountains which separate the sources of the Min from the river-land of the Yang-tszě. There many coffins had been 


\section{The religious system of China}

vol. I

severely damaged by time and weather, others were reduced to dust, and yet nobody seemed to care about the decaying bones. There were, however, also a good number closely covered in by a vault of masonry. Síp ts'ù of this description, invariably accompanied by a much larger number of uncovered coffins, I found also in many places near Nanking, even inside the city walls in the vast plains covered with rubbish, which were densely populated quarters before the double capture by the Thai-p'ing rebels and the imperial armies in 1853 and 1864 had reduced the town to ruins. Further I beheld the same spectacle around Kiu-kiang and Shanghai, in the hills about Swatow and Canton, and in many other localities.

In his rambles through various parts of the empire Dr. Gray also observed coffins near the sides of hills, in the open plains, on the banks of rivers and canals and, in some instances, by the wayside (144). Sometimes, says he, they were covered with matting, stones or straw, but as a rule they were uncovered. In the cities of Kiu-kiang, Chin-kiang, and in the town of Han-kow he saw coffins at the doors of houses in the less frequented streets, a custom, he was informed, arising not so much from a difficulty in finding lucky sites for interment, as from a reluctance to remove their dead out of their sight. This sentiment, he continues, prevails to a still greater extent at Yang-cheu-fu in Kiangsu province, where it is not unusual for tradespeople and others to keep their dead within their dwellings.

At Canton, the custom of storing coffins away for the want of proper burial sites, or because they are to be afterwards taken to the native place, has occasioned the erection of large buildings p.131 capable of holding several hundreds of coffins. To these chong, as they are called in the local dialect, mourners are in the habit of conveying their dead with funeral pomp, should the professor of geomancy have failed to find an auspicious grave-site in due time. They consist of long rows of rooms, each on an average ten feet by twenty and partly divided in two apartments by an open work screen across the middle. In the inner apartment is the coffin, generally resting on two inverted water-jars, because wooden supports are often attacked by white ants and might cause the coffin to fall to the ground. In the outer division is a table with candlesticks and an incense burner, in many instances also with a tablet for the soul ; there may be seen on the walls narrow scrolls of paper 


\section{The religious system of China}

vol. I

inscribed with poetical sentences. Light and air are admitted only by the doors in front, which open into an uncovered passage dividing two opposite rows of rooms.

Besides three large establishments of this kind, there are in Canton many smaller ones. Some are specially erected for the occupancy of natives of certain parts of the empire, who remain there until their relatives are able to take them to their ancestral home. The most interesting chong is situated at a distance of one mile beyond the east gate of the city. It is laid out, like the others, in the form of a small town, two of its sides being flanked by a lofty wall, loopholed for musketry. This precaution is taken against robbers, who sometimes remove the body of a person who has bequeathed wealth to his relatives, and hold it till a ransom has been paid. When a suspicion of anything of this sort is entertained by the relatives of the deceased, a few armed men are hired to keep watch by night. In the court-yard there is a pond, the east bank of which is planted with trees and shrubs. Attached to this same 'city of the dead' there is a garden with a large garden house. To this bower, persons, when visiting their dead, resort to dine, and many pic-nic parties are held here.

In each necropolis two or three Buddhist priests reside, whose duty it is to say occasional masses for the repose of the souls $(\underline{145})$. These institutions are all private property, but licensed by government. They are kept in good order, and at once strike the foreigner as being cleaner and neater in appearance than most of the abodes of the living. Besides an entrance fee, a monthly rent of from one to three dollars is paid by those who place their p.132 dead in the chong, the sum varying according to the means and the rank of the family. They are made use of also by those who postpone a funeral because they desire to lay father and mother in the grave at the same time. Sometimes coffins are left for years after the rent has ceased to be paid. Filial piety, even amongst the Chinese, may be dulled by lapse of time or increasing poverty ; men leave their homes hoping to return, but business, misfortune or death prevents their doing so ; people are reduced to poverty and, hoping for better times, they allow the chong rent to accumulate till death takes them off, or till their position with respect to the rent becomes irretrievable; families die out and coffins containing unclaimed bones are left in the hands of the proprietor 


\section{The religious system of China \\ vol. I}

of a chong. In such cases they are put aside in some inferior room, and if at the end of ten or more years they are still unclaimed, a report is made to the magistrate and permission to bury them is given, the expenses being defrayed by the contributions of those who wish to lay up for themselves a store of merit for good works ${ }^{1}$. Also in Fuhchow there exist some Cities of the Dead, but they are much smaller than those of Canton. No doubt inquiries would show them to exist in many other towns of the empire.

Postponement of burials, denounced by Law and Government.

The Chinese of all classes unanimously assert that it is quite incompatible with the all-pervading doctrines of the hiao to leave coffins unburied for any great length of time. It would indeed be difficult to find a man ready to contest the fact that burial is indispensable for the repose of the dead, and that postponement is nothing short of a calamity for the soul, which is then compelled to wander about in a state of sad disquietude. The fact that, in spite of these conceptions, so many coffins, mostly belonging to people of the best classes of society, remain unburied even for years, indicates better than anything else could do how firmly the mind of the nation is held in captivity by the fung shui theories, according to which a body ought not be interred except in a grave situated under the good influences of nature.

These theories, entailing so many sins against the hiao, have also been severely denounced by the Imperial Government. The Ta Ts'ing luh li or 'Laws and Statutes of the Great Ts'ing dynasty', p.133 the civil and penal code of the empire, says in its official commentary :

«The fung shui doctrines date from latter ages. At the bottom they are absurd and false, and not worthy of belief. Thinking that future happiness is transmitted to children and grandchildren by the decayed bones of father and mother, people postpone the interment of the latter for years, leaving the coffin uncovered and unburied : this is the highest degree of unfilial conduct.

\footnotetext{
1 Theos. Sampson, in Notes and Queries on China and Japan, vol. II, p. 110 seq.
} 


\section{The religious system of China}

vol. I

Filial conduct embracing in the first place implicit obedience to everything the parents desire, it is systematically enforced by the Government upon all its subjects as the highest social duty, because it is calculated that in this way every individual will be kept under strict authority and so order shall prevail in the whole empire. Consequently it is quite logical that the Code of Laws should interdict the practice of postponing burials.

«Any family, it says, in which a death has occurred, is certainly obliged to set the deceased at rest in a tomb, with observance of the established rites. He who, led astray by fung shui or under any other pretext, keeps a coffin with a corpse in it in his house over a year, leaving it uncovered and unburied, shall receive eighty blows with the long wooden stick.

But in China laws are not made to be implicitly obeyed. They only exist to serve the governing classes, in cases of need, as a means to uphold their authority and to prevent any disturbance of the public peace. Consequently anybody may at any time keep as many coffins unburied as he likes, so long as the local authorities are not seized with the humour of undertaking a crusade against the transgressors of the law. Edicts are then promulgated, threatening with severe punishments those who do not quickly inter their dead. A few persons are, perhaps, taken into custody to undergo a cruel bastinado, and to have their money squeezed out of them by the authorities and their underlings; but after a short time hiao, law, edicts and coffins are forgotten, and matters go on as before. Public health is never used p.134 as an argument against the practice. Such things never cross the brains of the Chinese, who all believe that diseases and epidemics are simply caused by evil spirits.

An event such as the above occurred in Amoy in 1882. The edict wherewith the Taotai or highest civil authority residing in that place opened the crusade, ran as follows :

«Sun, Intendant of the Circuit embracing the departments of Hinghwa, Ts'üen-cheu and Yung-ch'un in Fuhkien province, Controller of the Maritime military forces, promoted by the Emperor to the official rank of the second degree, 


\section{The religious system of China \\ vol. I}

- considers that the practice of storing coffins away and of neglecting burials must be prohibited and abolished.

To serve the living and to bury the dead is in fact commanded by the duties of a son, and by committing coffins to the care of others or by storing them away, souls of parents are actually deprived of anything whereon they can rely. Already at the very moment I stepped down from my carriage (to enter upon office here), I was informed that the practice of keeping coffins unburied was prevalent in Amoy country. I said to myself : The dead consider rest to consist in returning to the earth, so that a coffin kept one day unburied means a soul left one day without anything to rely upon; therefore, how can the minds of men deviate so far from the customs of antiquity that, deluded by the reasonings of geomancers, they so often keep the encoffined bodies of their parents for a long time unburied, thus causing the same to gradually become nests of mole-crickets and ants ! People wish only to make use of a set of unconscious white bones of their forefathers as implements wherewith to seek fame and glory for their descendants; but they simply forget that wealth and consideration in human life are from the outset fixed by Heaven, so that it is impossible to secure greatness and glory to posterity by a selection of lucky spots for burying. Such things are detrimental to good manners and customs, and, even were there no articles in the Law positively proscribing them, there are feelings of the heart which cannot tolerate their existence.

From the moment this proclamation is issued, I expect that all the soldiers and citizens of Amoy, who may be keeping coffined corpses in their houses or may have stored them away in Buddhist temples, shall have all of them carried out for burial within three months. If any one venture to delay the burial beyond this period and thus oppose this order, I will investigate the p.135 case immediately and pass sentence without leniency or pardon. Do not resist this special order.

Issued in the $8^{\text {th }}$ year of the Kwang sü period, on the $21^{\text {st }}$ of the $7^{\text {th }}$ month. 


\section{The religious system of China \\ vol. I}

Treatment of corpses of unknown or murdered persons.

Before finishing this subject we have still to mention, that postponement of burial is also of very frequent occurrence in cases of wilful murder or manslaughter, and when the corpses of unknown persons are concerned. The Ta Ts'ing luh li has the following article :

«When a person is found dead within the precincts of a place, the headman of the village and the people living in the neighbourhood shall be punished with eighty blows with the long wooden stick if they neglect to inform the Magistrate of the fact, that he may hold an inquest, or if they arbitrarily transfer the corpse to another spot, or bury it. If in consequence of their proceedings the corpse has disappeared, the chief culprits shall receive one hundred blows. In case the body is mutilated or cast into the water, the chief perpetrators shall have sixty blows and be deported for one year ; and if it is cast away but not lost, or the hair is injured, one degree less punishment (i. e. one hundred blows) shall be inflicted upon all of p.136 them. If people steal the clothes they may be tried for ordinary theft, and their punishment fixed in accordance with the value of the things appropriated.

As a natural consequence of this law, no unknown corpse found dead is ever touched until official permission has been granted to remove or bury it. Even if on the point of dying or only apparently dead, the body is left on the spot without a helping hand being stretched out to it. Indeed, any good Samaritan in China would be called a fool ; for, should the object of his pity happen to die, the grateful family would at once attack him as a welcome prey out of which to squeeze money. Flatly accusing him of having murdered the man, they would give him the choice between paying a large sum as an indemnification, or having a complaint lodged against him with the magistrate. If he prefer the denouncement, he is immediately imprisoned and subjected to the most ignominous ill-treatment by the jailers, unless his family bribe these men with large sums to leave him alone and let him have food enough to keep him from starvation. The flogging and tortures, which he has to suffer in the tribunal, like everybody who falls into the hands of the 


\section{The religious system of China}

vol. I

mandarins and who does not forthwith confess his guilt, need not be expatiated on. This pretty state of affairs also compels every inn-keeper, who happens to have a lodger who is seriously ill, to carry him clandestinely out of his house before he breathes his last, and to lay him down somewhere in the street, to die miserably of cold and hunger, and for want of assistance.

The laws of the empire prescribe that the magistrates shall hold an inquest on the body if there are traces of a violent death upon it. The headman of the ward in such a case immediately sends a message to the District Magistrate, to inform him of the matter. But as a rule a couple of days elapse before this worthy makes up his mind to do what his duty requires, and during the whole of this time the corpse is left untouched in the narrow street, to the frightful annoyance, especially in summer, of the olfactory nerves of neighbours and passers-by. At last the magistrate is conveyed p.137 to the spot in his sedan-chair, escorted by the usual retinue of lictors and attendants, and stations himself underneath a sort of tent, pitched windward of the spot where the corpse is lying. Here some chairs have been arranged for his convenience, as also a table with writing materials.

Now, a sort of coroner called $g \underline{\bar{a}}$ tsoh, a functionary of very inferior rank attached to the Yamen, begins to wash the body with a lukewarm decoction of onions and other ingredients, which is believed to possess the property of rendering injured places more conspicuous. If the corpse has been long on the spot, this washing destroys a great part of the epidermis. When it is over, the coroner inspects every part of the body, probing it with his fingers and with a chopstick; and after he has examined each limb he turns himself to the mandarin, to kneelingly report with the assistance of an interpreter whether an injury has been detected on it, of what nature it is, by which instrument it is likely to have been produced, and so on. All his depositions are carefully taken down by a secretary. Thereupon the mandarin and the lower officials of his suite, holding handkerchiefs or towels to their mouths and noses, proceed towards the body to look at the injuries reported by the coroner. Then they purify themselves by passing through a small fire of straw kindled on the pavement, and get into their sedan-chairs to return home. At this moment, the bystanders explode a large quantity of fire-crackers, to frighten away the bad influences of death. This double process of purification 


\section{The religious system of China}

vol. I

is repeated at the gate of the Yamen when the procession re-enters. The costs of the fire-works, the tent etc. have to be defrayed by the relations of the dead, if any have been found, otherwise by the headman and the inhabitants of the ward.

At Amoy such a coroner's inquest goes by the name of giēm si, 'to hold an inquest on a corpse'. Elaborate precepts regulating such procedure are laid down in a work called Si yuen luh, 'Book on the Redress of Wrongs', which was published in the $13^{\text {th }}$ century and is officially appended to many copies of the Ta Ts'ing luh li. Its minute indications, often very amusing, how to ascertain the cause of nearly every kind of death resulting from accident, murder, poison or any suspicious circumstance, form a p.138 rich mine of information regarding the Chinese ideas on physics and anatomics ${ }^{1}$.

The inquest over, the corpse is left at the disposal of the relatives, to be coffined. If, however, the family of the dead is unknown, the headman of the ward collects money for a coffin among the people living around, the highest contribution being levied on those who dwell nearest to the spot where the corpse has been found and who are therefore more than others interested in its removal. But in most instances it is not even now allowed to be committed to the earth. A second, nay, perhaps a third coroner's inquest may be deemed necessary by the authorities to verify statements made by witnesses or persons implicated; and even when putrefaction has done its work, the mandarins may for the same purpose think it useful to scorch or boil the flesh or bones, or to burn parts of the skeleton, which proceedings are all conducted on rules laid down in the book mentioned above. There is no question of burial if the culprit or the culprits have not been detected. Consequently the coffin is deposited somewhere near the spot where the body was found, there to remain in charge of the headman and the inhabitants of the ward until it is claimed by the authorities. Sometimes they screen it from view by a thatching of straw, matting or boards. Scarcely ever is it buried before the judicial investigation is crowned with a satisfactory

\footnotetext{
1 A translation in Dutch was published by Mr. De Grys in 1803, in vol. 30 of the Transactions of the Society of Arts and Sciences at Batavia.
} 


\section{The religious system of China \\ vol. I}

result and sentence has been passed on the culprits, after which the main piece of evidence is, of course, no more wanted.

If the judicial inquiry has pointed out that there is no question of premeditated or wilful murder, but only of manslaughter, and the culprit has been sentenced to pay an indemnification to the family of the slain, the coffin is kept unburied until the fine has been paid in full and therewith the whole affair settled. When villages have been in bloody encounter with one another, which in many parts of the empire is a matter of almost daily occurrence, the same line of conduct is followed with regard to the slain outnumbering those who have fallen on the other side, because, should peace and mutual understanding be afterwards restored, a retribution will have to be paid for that surplus.

In the event of an unknown person having been found dead without marks of violence on his body, so that the magistrates do p.139 not deem it necessary to hold an official inquest, the neighbouring people, as soon as they become aware that the family is not to be found, coffin the corpse under the superintendance of their chiefs and elders, and deposit it somewhere in the hills or the open fields. Want of interest in the deceased prevents the people from doing more in his behalf. The coffin, which is in many instances supplied by a benevolent society, is as a rule of a very bad quality, so that during several days there emanates from the body a most sickening smell. After some time the wood decays and the bones remain scattered about the spot, until some one, anxious to derive a small supply of merit from an act of benevolence and to obtain a good reward from the soul, covers them with earth. In many instances such bodies are forthwith interred by the neighbours in one of the public grave-yards, which benevolent societies have laid out near most towns for the poor who cannot afford to buy their own graves for their dead. 


\section{The religious system of China \\ vol. I}

\section{CHAPTER VII}

\section{The burial}

Preparations and introductory rites.

p.140 On page 103 it has been stated that a lucky day and auspicious hours have always to be selected for the burial if the same takes place seven or more days subsequent to the demise. As in such cases the day-professor generally delivers the results of his calculations a good number of days beforehand, the mourners have plenty of time to arrange everything for the burial at their leisure. This is amongst the wealthy a matter of no small importance, as they are accustomed to send a father or mother to the tomb with a pomp that entails long and difficult preparations.

Arrangements are in the first place made with one or more undertaker's shops, which, as was said on page 13, provide for temporary use all the principal requisites for a funeral train, as also the necessary workmen, coolies and musicians. Further, written messages are sent round to graduate acquaintances and intimate friends, inviting them to kindly officiate in the cortege as overseers of the bearers of the coffin and of some portable tents of particular interest, or to act as leaders in certain subdivisions of the procession. Notable families in some instances distribute printed notifications among kinsmen and friends, announcing the day and hour of the ceremony and containing a polite request that they will not attend the funeral. But these documents mean just the opposite of what they express, and are in reality a formal notice that the family sets much value on the presence of kinsmen and friends and by no means expects that they will be absent.

The haò png sacrifices with the introductory howling ceremonies kiò khí and kiò khùn (p. 115) are performed anew on the two days preceding the burial or, in a few cases, even on six days ; in conclusion it is repeated on the morning of the burial day itself. In the course of this morning, when the hour fixed by the day-professor as suitable for setting the coffin in motion has 


\section{The religious system of China}

vol. I

arrived, a certain number of workmen, despatched by the ${ }_{\mathrm{p} .141}$ undertaker, shift the bulky object a couple of inches, during which proceeding the members of the family hide themselves in the inner apartments to escape the wrath and anger of the spirits of the earth who, shaken out of their rest by the motion of the coffin, might revengefully leap upon the bystanders (comp. page 105). Each workman shields his own person against such dangerous assaults by winding his headkerchief round his waist. As a compensation for the danger to which they have exposed themselves notwithstanding, they are rewarded by the family with an extra fee in money. If it is still too early for the burial, the coffin is now left on the spot, until the fit moment for its removal arrives.

Meanwhile the females and servants are busily occupied in the kitchen, as a bounteous meal must be offered to the dead before he is sent to the tomb. The edibles, which consist of several meats, fowls, ducks, cakes and the like, are arranged on one or more tables in front of the coffin and the hûn péh. As a rule the number of dishes is even, because even ciphers are identified with the principle of death and darkness Yin (see p. 65). Burning tapers are placed in the candlesticks, to light the soul while partaking of the meal. When everything is ready, the mourners, clad in the deepest mourning prescribed according to each one's special rank of relationship, advance and wailingly kneel down in front of the tables, the males keeping to the left, the females to the right. The principal mourner, that is to say the eldest son, stands before the table, takes burning incense-sticks between his thumb and fingers and, clasping his hands together, makes an obeisance to the spirit, thereupon informing it that, the hour of interment having arrived, a farewell dinner has been affectionately set out on its behalf. He now places the incense in the censer and kneels down on the floor. One of the more removed kinsmen of the dead, who acts as an attendant, then pours a little rice spirits into small porcelain cups that stand in a row on the table, and immediately repeats this twice successively, thus filling the cups to the brim; this rite is called sam hièn tsiú, 'threefold presentation of spirits'. When it is finished, the principal mourner bends his forehead to the ground three or four times, wailing in this position a few seconds at the fast bow, and then he gets up to allow the other relations to p.142 perform similar acts of worship in the order of proximity. It 


\section{The religious system of China}

vol. I

often occurs, however, that want of time prevents a great number of them from doing so. All the while the mourners keep up a piteous wailing and lamenting. In the end it is ascertained by means of the two divining cash whether the soul has finished his meal. If so, a quantity of mock money is burnt and the tables are cleared.

This ceremonious sacrifice is designated khi bé, 'to start the horses'. The term owes its origin to the fact that, as the $I$ li and the $L i$ Ki teach us, horses were anciently used in burials of grandees to convey carts loaded with sacrificial articles and other things to the tomb; now-a-days, however, no animals are in Fuhkien ever used for such purposes. Ceremonious and solemn though the khi bé sacrifice be, it is only a poor ceremony compared with the entertainment that is shortly afterwards, at the moment of starting, offered to the soul in the street.

Two or more tables are arranged there near the door. The principal mourner, a relative or a friend reverently places the hûn péh upon one of those tables, taking care it faces the direction in which the procession is to go. At its side, or just behind it, comes the permanent soul tablet, which after the interment is to harbour the spirit and now makes its appearance in the obsequies for the first time. A piece of red silk and a skein of threads of the same material and colour are tied around it ; a few copper coins string on a red cord, a stick of vermilion ink wrapped in a sheet of paper, and an ordinary writing pencil are fastened in front ; in many cases, a twig bearing a few gilt leaves or flowers is stuck in the red cloth on both the left and the right side of the tablet. It would carry us too far from our subject to enter upon a description of this tablet. Full particulars about it will be found in the Second Book, which is devoted entirely to the human soul and its worship. We here confine ourselves to stating that it is an object much like the hûn péh, but lower and broader; it does not taper away at the top, neither is it covered with silk, the inscription being written or cut out on the wooden surface.

The sacrificial tables are loaded with a variety of dishes, bowls and plates, containing various sorts of food. As a rule the sons provide at least one set of so-called ngó sing or 'five sacrificial viands', being five open platters which hold respectively a pig's p.143 head, a fowl, a duck, a fish and a pig's tripe, 


\section{The religious system of China}

vol. I

with slight variations according to circumstances. The married daughters are in duty bound to do the same, but in many instances every child provides a set, especially if the deceased is a person of great distinction. Thus the number of dishes is often very great, even exceedingly so when the children are anxious to give testimony of their affection and respect for the deceased by adding many more dainties and articles of food.

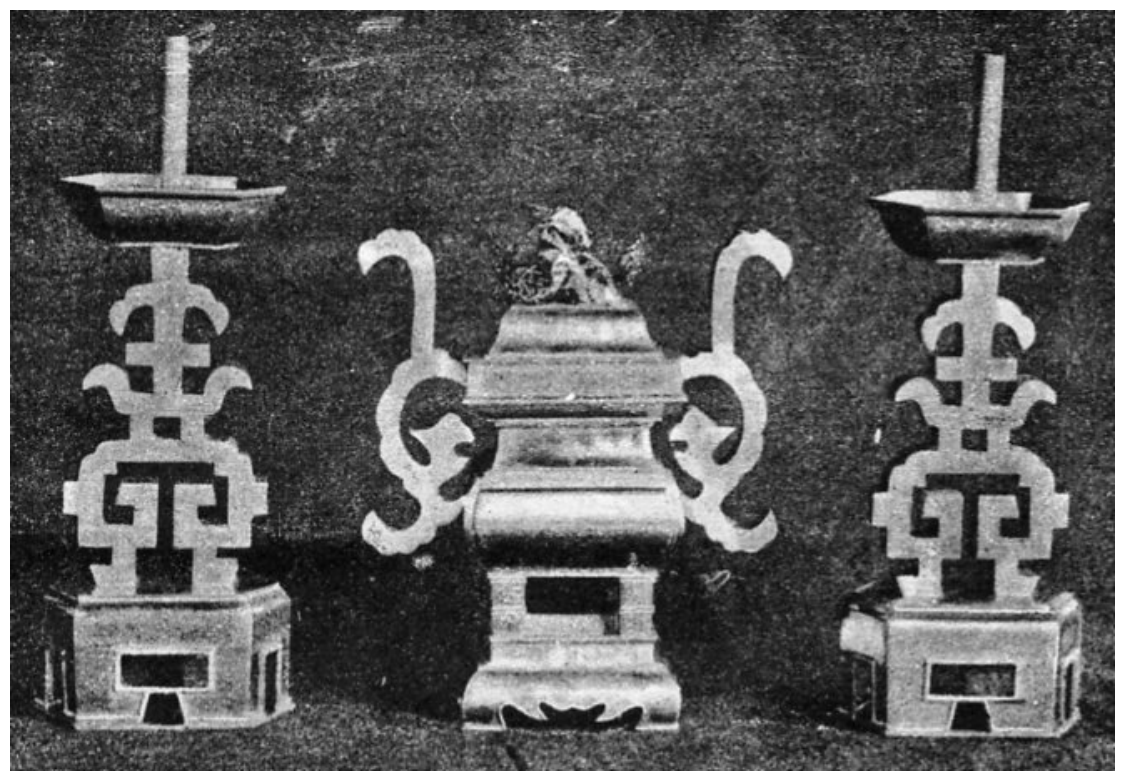

Fig. 12. Candle Sticks with I ncense Burner.

Amongst the offerings are a couple of tapers, placed in candle-sticks of tin which have the shape of the character [], 'long life'. Between them stands a so-called kong-pô lố, or 'incense-burner for the ancestors'. It is square, has a cover and four feet, and on each side a big ear or handle; it stands in a square plate or tray which, like the censer itself, is of tin. All these instruments, which are depicted in Fig. 12, are taken from the p.144 domestic altar, of the furniture of which they form a part. In front of the edibles are also arranged some sexangular flat-bottomed tsiú pân or 'wine tankards' of tin, tapering away at the top and closed with a cover ; each has a spout and a handle. Of these instruments, filled with spirits distilled from rice, there are as

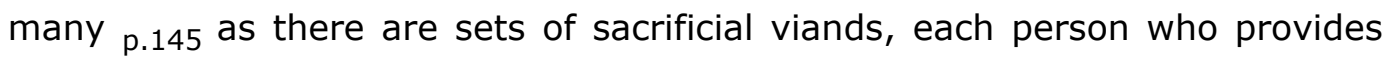
such a set being bound to add a tankard. There is also one larger tankard of tin, round, with a long and narrow neck closed with a caver; the spout is elegantly curved and, like the handle, very slender. This flacon goes by the name of Iō-si pân, 'heron jug', because its elegant and slender shape reminds 


\section{The religious system of China}

vol. I

one of this aquatic bird. With three tin globular cups called tsiú tsiok or 'winegoblets', having two ears or handles, three feet and, at the opening, two flat, projecting mouths, these form a set of instruments which are generally used for wine libations on the most solemn occasions (see Fig. 13).

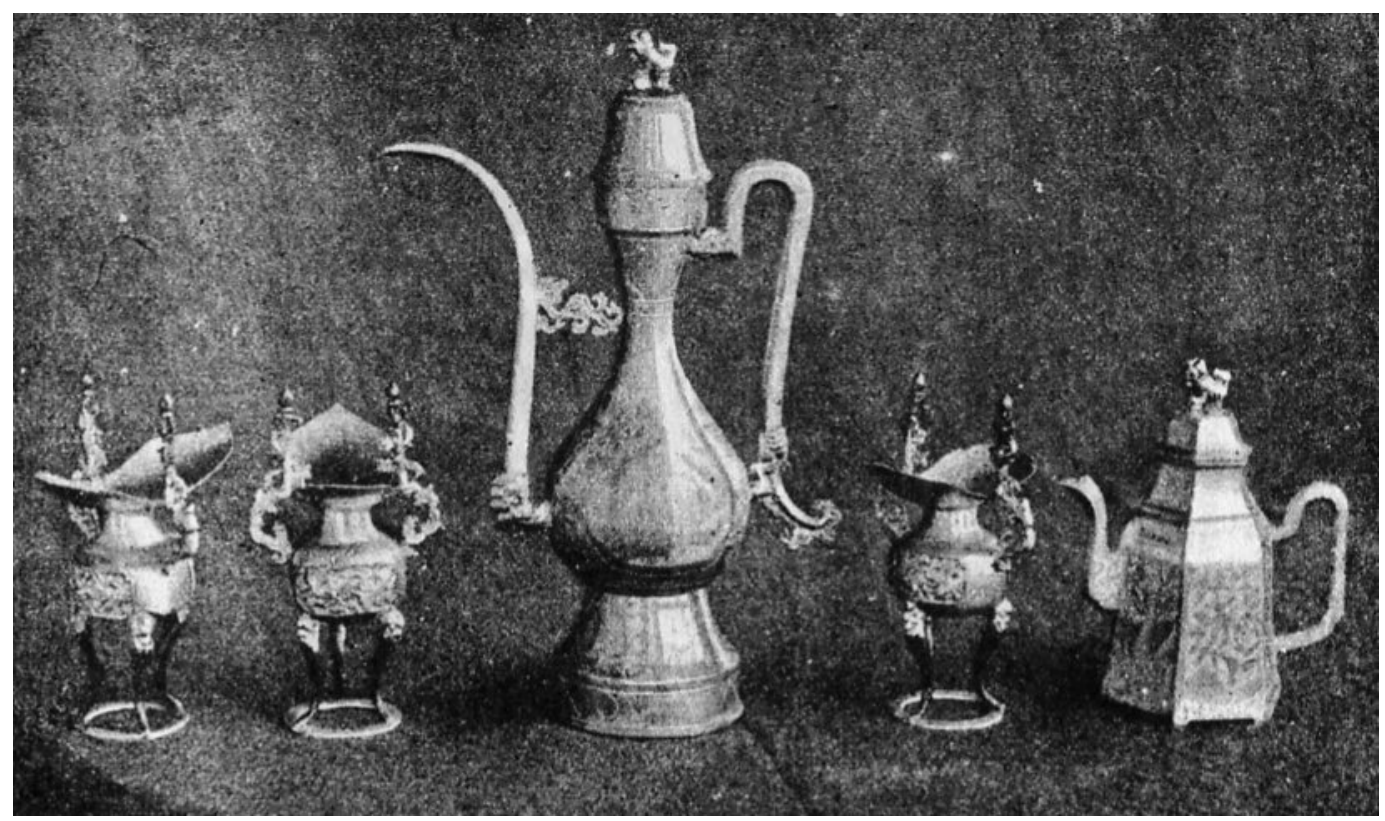

Fig. 13. Sacrificial Goblets with Heron J ug and Wine Tankard.

While the offerings and sacrificial implements are being arranged on the tables, a curious ceremony may be witnessed on the part of the coffin bearers, who have in the meantime placed the hearse, on which the corpse is to be carried to the grave, upon two low trestles behind the tables. Some of them busily occupy themselves with putting small sheets of mock money between the gaping joints of the hearse. Others place a few dishes of meats and other eatables, provided for this purpose by the mourning family, on the pavement, after which one man pours out spirits from a tankard into three little earthenware cups arranged on the spot, and the headman, having taken burning incense-sticks between his thumb and fingers, makes a couple of bows to the hearse. A bonfire of paper money closes the ceremony. The food is carried off by one of the coffin bearers, who will divide it with his fellows as an extra emolument for their services. This sacrifice is intended to propitiate the spirit that is supposed to inhabit and control the hearse. As Mr. Doolittle, who observed the same practice at Fuhchow, has very judiciously remarked, 


\section{The religious system of China}

vol. I

« it will cause the soul of the departed to be more peaceful en route to the grave than it would have been had the sacrifice not been made ; it will help the bearers to carry it more easily ; it is feared, unless it is done, the god of the hearse will injure the coffin in some way, making it difficult and heavy to bear (146).

When everything is properly arranged, a piece of sackcloth, white cotton or linen is suspended between the fore-legs of the foremost sacrificial table, and the coffin ordered out. Scarcely p.146 have the bearers set to work to move it, when all the bystanders rush into the adjoining apartments, especially in case it has not yet been shifted as described on p. 141. But instantly the principal mourners re-appear wailing, to follow the dead out of the house. The coffin is carried across the threshold feet foremost and placed on the hearse, the feet pointing towards the tables and accordingly in the direction which the procession is to take. The sons, dressed in hempen sackcloth like the other principal mourners, each carry, as a token of the deepest sorrow, a mourning staff, which is a very short stick pasted all over with thin curls of white paper. The more distant relations, in white linen or cotton garments, come out after them, and all kneel round the coffin, pouring forth the most piteous lamentations and death dirges. Meanwhile the coffin bearers fit on carrying poles and ropes to the hearse, and place an embroidered pall over the coffin, scarcely anything being done much unedifying vociferation.

While one of the several bands of musicians, that is to do duty in the funeral cortege, sends forth the discordant tones of its instruments into the narrow street, some friends or more distant kinsmen, clad in white mourning, take up a position in front of the sacrificial tables, one or two on the right and the same number on the left side. They are to officiate as attendants or masters of the ceremonies. One of them holds a thick bundle of incensesticks. The principal mourner, creeping along the pavement in token of the deepest grief, advances to the table. Out of the hands of the fast mentioned attendant he receives two burning incense-sticks, with which, his hands clasped together, he makes a deep obeisance to the tablets and the coffin. Thereupon he gives the sticks to an attendant on the other side, who immediately plants them in the ashes of the 'incense burner for the 


\section{The religious system of China}

vol. I

ancestors', and then he kneels down upon the pavement, to bow his forehead to the ground four times in succession.

Meanwhile another of the assistants performs the threefold presentation of spirits described on p. 141, in a long row of earthenware cups arranged for the purpose on the table, using one of the sexangular tankards. The mourner, without rising to his feet, now receives one of these cups or, in case of the well-to-do, a tin wine goblet, and has spirits poured into it from the 'heronjug' by the fourth attendant; thereupon he moves the goblet upwards as if to present it to the soul, and slowly pours the contents over the ground by a circular movement. This libation goes by the ${ }_{\text {p.147 }}$ name of koàn tōe, 'to pour over the ground'; it is also called tiēn tsíu, 'to make a libation of spirits', or, in literary style, koàn tiēn, 'to pour out a libation'. When it is finished, the assistant on the other side places the cup on the table again, whereupon a second and a third cup are consecutively presented to the dead in a similar manner.

Now follows the third part of the ceremony. The wailing relatives suddenly put a stop to their lamentations, the musicians to their music, and one of the attendants, kneeling down devoutly, reads in the mandarin tongue an address to the soul from a sheet of yellow paper. Here is a translation of such a document, taken from real life :

«In the thirteenth year of the Kwang sü period, being the cyclus year ting-hai, in the first or jen-yin month and on the day jen-ch'en, which is the third from the new moon, the unfilial orphan son Kung-ch'u and the other mourners, respectfully presenting an offering of sacrificial viands, must, sundry delicacies, incense and paper, venture to address the soul of their departed father, chief of the family Ngeu-yang, in the following terms :

Man's innate nature harbours disparate inclinations, but in our father's character kindness and benevolence were sublime. We were just living in the hope that Thy overflowing virtue would enjoy a long existence, blessed with strength ; but who could have expected this would be a 


\section{The religious system of China}

vol. I

mere dream of ours, a dream of yellow millet ${ }^{1}$, out of which we would not awake to behold p.148 its realization ! Like a white cloud Thou hast passed away to go to the West, and it is in vain we look up to Thee, in order to continue our reliance on Thee; so we have founded a nice city (i. e. a grave), of which we venture to tell Thee some particulars, to wit that p.149 we have selected a first rate plot of ground on the sunny side of the mountains, and there have laid out a quiet abode on the borders of the water. The revolving wheels of the bier now fill our souls with pain and grief; the men who grasp the ropes to draw it forth afflict us and pierce our hearts. There will be no more opportunities to serve Thee by holding up the washing basin 2 ; what way is there to receive the smiles from Thy face again! Seeing the foremost carts drive off, we cry to Heaven from the depths of our souls and invoke the pity of Earth. We set out a sacrifice of viands to give testimony of the sincerity and depth of our feeling, hoping that Thou mayest come and taste of the offerings. Alas, what woe! Mayest Thou enjoy this our sacrifice!

At the words 'Alas, what woe !', which are expressed in a very plaintive, protracted tone of voice, all the mourners suddenly join in an outburst of pitiful wailing. The musicians at the same moment pour forth the shrill tones

${ }^{1}$ A dream of yellow millet means a short dream of happiness. The expression owes its origin to a popular legend, of which one version runs as follows.

"In the 'Records on the Inside of the Pillow' it is related, that in the period Khai yuen (A. D. 713-742) Lü Wang mastered the mystic arts of the gods and the immortal beings. Wandering about in Han-tan (in the south-west corner of the present Chihli province), on the road he fell in with a young man of the name of Lu Sheng, in whose company he passed the night at an inn. With sighs this person revealed to him his poverty and misery. When he had finished speaking and thought of going asleep, Wang took a pillow from his bag and offered it to him, saying: "Lay your head down on this, then you will attain to glory, and whatever you may desire shall fall to your share". Sheng did as he was told and dreamt that his person crept into the inside of the pillow, that not long afterwards he was appointed to an official dignity, that during fifty years he was promoted from one high office of state to another and that, having enjoyed unparalleled glory and prosperity, his life was translated on a certain day. At this point he awoke from his sleep; Lü Wang was still by his side and the yellow millet, which the inn-keeper had on the fire, was not yet done. »

See the Liao ch'ai chi $i$, ch. V, the appendix of the tale entitled []. Also the Pei wĕn yun $f u$, ch. XXII, 3, leaf 85.

2 An allusion to one of the duties of children as prescribed by ch. 39 of the $L i k i$ : see p. 119. 


\section{The religious system of China}

vol. I

of their instruments into the melancholy concert, and one of the attendants burns the prayer, thus dispatching it to the soul by means of fire and smoke. The principal mourner, who up to this moment has not risen from his kneeling posture, now bows his head to the ground four successive times and creeps on all fours over the pavement to the other mourners prostrated at the side of the coffin, there to wail and lament in concert with them.

After him, the mourner next in rank creeps towards the table, to offer incense and wine in just the same manner. The other sons and their wives, the unmarried daughters and the grand-sons of the dead subsequently go one by one through the same ceremony in regular order of proximity and age ; but if the approaching auspicious hour for lowering the coffin into the grave does not allow them sufficient time, the libations are omitted by those at least who have not presented a set of sacrificial viands. When every one has taken his turn, a mat is placed on the pavement and covered with a piece of red cloth, lest the brothers of the dead and the other mourners in the second degree, who may be prompted by feelings of respect and affection to pay homage to the deceased by an offering of incense and spirits, should be compelled to kneel on the bare stones. But none of them touches the cloth with his p.150 knees before he has folded up one of its corners, to express his willingness to dispense with the cloth, as the mourners of the first degree have done. They neither advance to the table, nor retire from it, in a creeping attitude. The relatives who have to wear mourning in a still lower degree, come last. They do not perform a libation, but content themselves with presenting incense and making prostrations ; in the end, especially if time presses, even the incense offering is omitted, and all simply bow their heads to the ground in groups of twos or threes at a time. In very fashionable families, a friend or distant relative, stationed a little to the rear on the right ride, kneels down and prostrates himself simultaneously with each of the worshippers of the third and lower degrees : an act of courtesy prescribed by the rules of etiquette, which goes by the name poé pài, 'to keep company in prostrating'. It is noteworthy also that many a kinsman, on bowing his head to the ground, at the last bow bursts into a short fit of whining without lifting up his head, as if he were so overwhelmed with grief as to be unable to rise. Two other kinsmen immediately rush up to him, to help him on his feet. 


\section{The religious system of China}

vol. I

The last of the prostrations and libations is a sign for the funeral procession, which has meanwhile been arranged in the street, to prepare for starting. Some of the friends, kinsmen or servants hasten to set on fire a quantity of mock money on the pavement, while the coffin bearers, loudly vociferating, take the bier upon their shoulders, violently kicking down the trestles on which it was placed. At this moment the principal mourners lay their hands on the bier with a new outburst of lamentation, as if to prevent their beloved parent from being carried away, and then they arrange themselves behind it, wailingly following it to the grave.

The ceremonious farewell sacrifice here described is called khi ts'â-thaô, which means, 'to take the coffin away', as the word ts'â is obviously an abbreviation of $k a^{n}$-ts'â, 'coffin'. Music accompanies the solemnity from the beginning to the end. At same fashionable funerals, three or five Buddhist priests, dressed in ceremonial robes of the highest order, are employed to recite in front of the sacrificial tables the Amitâbha Sûtra and some invocations, chants and prayers, before the mourners enter upon their libations. These sacerdotal rites, which are called ${ }_{\text {p.151 }}$ khai $I \bar{o}$ ts'àm, 'rituals to open the way', are intended to obtain admission for the soul to the western regions of bliss. When they are over, the priests arrange themselves in the funeral train, to further the salvation of the soul by muttering along the way without intermission Amitâbha's sacred name.

Sacrificing to the dead outside the dwelling at the moment the coffin is carried out for the tomb, is a custom of old standing. After having described how, in case of ordinary officials, the coffin was, on the day preceding the burial, taken to the ancestral temple and left there in the open court-yard with an offering of eatables at its side, the $I$ li gives an account of a bounteous farewell sacrifice presented on the same spot, which rends as follows :

«On the next morning, five caldrons are arranged outside the gate as formerly, (that is, as at the sacrifice connected with the coffining). They contain the left side of a goat without the leg, and its five intestines and five stomachs, exclusive of the lungs. Further there is a similar part of a pig, cut into pieces, but without any of its intestines or 


\section{The religious system of China \\ vol. I}

stomachs. There are also fishes, dried meat, and fresh meat of quadrupeds, altogether the same as formerly. On the east of the court-yard are set out : four pots, respectively holding $p^{\prime} i \operatorname{sih}^{1}$, pickled meat of bivalves of the kind pi, uncut kwei pickles and pickled meat of snails; - four baskets, respectively with jujube fruits, cakes of parched rice or of flour, chestnuts and dried fruit ; - must, and spirits.

The torches having been extinguished, candle-bearers keep near to the thill-ropes of the catafalque, facing the north. The guests who enter the gate are saluted with bows (by the principal mourner). Now the caldrons are taken inside the gate and the offerings put down (on the west side of the catafalque). The pots are so placed that the principal ones come on the south; they are tilted over. The baskets come on the south side of the dried snails' meat, the principal on the north, and they lie tilted over also. Each stand for the meats is loaded with two pieces, of which the principal is on the south. They are not tilted over. There is an extra stand for the fresh meat of quadrupeds.

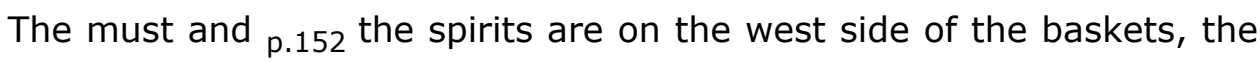
principal article (i. e. the must) on the north.

The men who have put the offerings in their places now leave the gate, the mourners stamping their feet at the important moments.

That during the Cheu dynasty the sacrifice in question, which the I li calls 'sacrifice at sending away the dead' did not merely exist in theory, is fully testified by the Li ki. Chapter 13 of this Classic (I. 11) relates that Tszĕ-yiu, Confucius's disciple whom we had occasion to introduce to our readers on page 32 , said on a certain occasion :

«Immediately after the demise there is an offering of dried and pickled meat; when the corpse is about to be carried off, the sacrifice of sending it away is performed and thereupon it is conveyed away ; and after the interment food is presented to the deceased. Nobody has ever seen the dead enjoy these offerings, and yet, from the remotest ages to the present time nobody has ever neglected them.

\footnotetext{
${ }^{1}$ It is not known what $p^{\prime} i$ sih was. Ching Khang-ch'ing says, it means [], 'centifoil' ( ?)
} 


\section{The religious system of China}

vol. I

The funeral procession.

Funeral processions as a rule may be said to differ from one another rather with regard to show and length than with regard to arrangement. The wealth of the family, the social rank of the dead and the consideration in which he was held during his life, the position of his sons, the number of his friends and acquaintances, etc. have a must decisive influence on the pomp p.153 displayed in the train and on the number of persons and groups composing it. One may sometimes see corteges of not more than a dozen people, whilst others consist of many hundreds. Public opinion is wont to judge of the filial devotion of mourners from the way in which they celebrate the obsequies of their parents. Consequently, in burying a father or a mother, sons scarcely ever neglect to spend as much as they can afford on the cortege, everybody in China being most anxious to show that he possesses such filial conduct, the cardinal virtue of the nation, in the highest degree.

In the following pages we intend passing in review a funeral procession of the highest classes of society. In this way our description will be pretty complete, and the reader can then easily judge for himself which groups fall out at the funerals of the lower classes and the poor.

A kinsman or a friend of the family, in a mourning dress of white linen and with a cap of the same material on his head, opens the procession. His function is to clear the way in a polite and peaceful manner. Wherever he comes across anything which obstructs the passage, as e. $g$. a bench or counter on which articles are exposed for sale, a portable furnace belonging to an ambulant cook who sells warm food to the people in the streets, a load temporarily set down by a cooly who is taking a rest or food, or any obstacle of the sort, he requests the owner to remove it, at the same time offering him, by the hands of a cooly who follows at his heels, a piece of a betel-nut and a little wet lime-dough, wrapped in one or two siri-leaves. This cooly, who wears no mourning, carries a basket of these articles for distribution. In southern China, the chewing of betel and siri as a stimulant seems to have been very common in bygone centuries, but it has now almost entirely died out, being supplanted, it would appear, by tobacco and opium-smoking. Nevertheless, probably as a survival of those good old times, it is still 


\section{The religious system of China \\ vol. I}

customary for any man living at variance with another, in case he desires to apologize and accommodate matters, to send some of those articles to the latter's house like a flag of truce ; and it would be considered highly improper on the part of the party, to whom the hand of reconciliation is tendered in this way, to refuse to accept the same. This fully explains why betel and siri are also distributed at funerals. Indeed, the clearer of the road confesses himself in the wrong with regard to the person whom he disarranges, and accordingly he immediately p.154 makes his apologies. In many instances, clearing the road is simply entrusted to the cooly alone; at most of the plainer funerals it is entirely omitted.

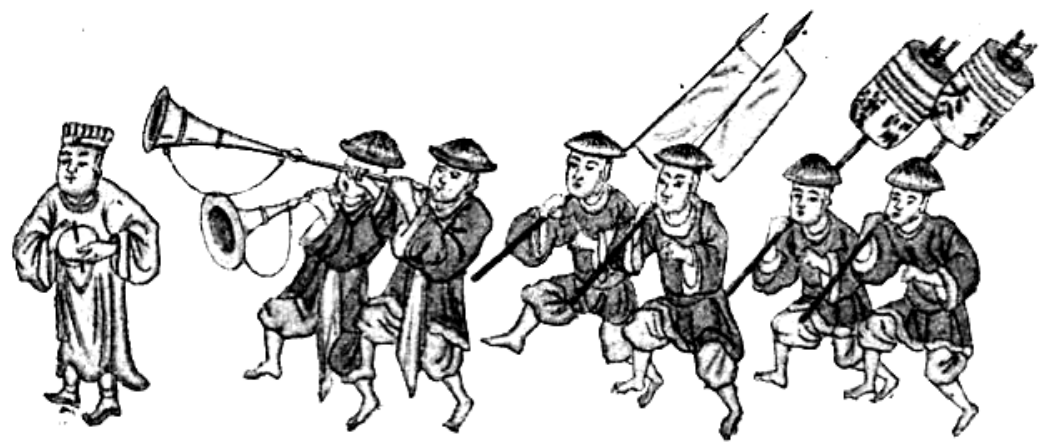

Fig. 14. Paper-Scatterer, Trumpeters, Flag and Lantern Bearers in a Funeral Procession. (From a native Drawing)

Next follows a so-called pàng tsoa ê lâng, or 'paper-scatterer' (Fig. 14). This is a distant relation, a friend or an acquaintance, likewise dressed in a white robe and cap, or, in some cases, in sackcloth. His function is to strew round or octangular sheets of tinned paper, from eight to ten centimetres in diameter, along the road, and also in the water when the train has to cross a creek or stream by a bridge or in boats. A great number of these sheets, strung on a little stick like metal coins on a cord, he carries in his hands for the purpose. This paper money is destined for the malevolent spirits who, according to the popular conception, prowl about everywhere and infest streets and thoroughfares, mountains and forests, rivers and creeks, causing all sorts of mishap to befall men. Wisely concluding that great numbers of these beings, hungry and miserable because of their not having been cared for by a dutiful posterity, must be swarming chiefly on the roads where coffins have to pass, for the express purpose of robbing, by importunate begging or by brute force, every deceased person of the money wherewith the living 


\section{The religious system of China}

vol. I

have so unselfishly enriched him during the funeral rites, the measure in question is recurred to in order to divert their attention. Like p.155 famished wolves on their prey, the spirits rush upon the money, and thus forgetting both coffin and soul, permit the procession to pass by unmolested. In numerous cases the tinfoil is coloured yellow, that the sheets may represent golden coins. Many families in easy circumstances prefer to use square sheets of good white paper, such so-called péh tsîn or 'white money' being higher in price than tinned paper and consequently more valued by the unseen spirits. Both sorts of mock money bear the generic name of bóe $\underline{\underline{o}} t s i^{n}$, 'paper to buy off a passage'.

Not seldom the distribution of siri-cuds is also entrusted to the paperscatterer. It is, moreover, incumbent on this man to affix a small shred of red cloth to every street-gate through which the procession passes, and to every bridge which it has to cross. The baneful, inauspicious influences emitted by the cortege of death are thus kept away from those spots and prevented from settling on the spirits which inhabit and control the same; if the family should neglect to show this little attention, it might experience the wrath and anger of those beings, in other words, incur sundry misfortunes. For a similar reason, the man with the siri-cuds and the paper-scatterer, at every temple they pass, warn the custodian, or the persons loitering about the premises, to shut the door quickly, in order to prevent the divinities from being seen by the cortege. At some temples, instead of closing the door, they lower a nicely sculptured and painted triangular wooden board, which, with a view to such cases, hangs from a pulley in front of the gods.

Much though the unseen spirits may be propitiated by such liberal gifts of paper money, these are by no means deemed a decisive expedient to keep them at a respectable distance from the funeral train. Two long trumpets of copper, with a thin sliding tube and curved-up mouth, are still required to frighten away those among them on whom the distribution of money has no effect. These instruments, which are called hō thaô or hō siú, 'signal-heads', are not proper musical instruments, as they only give two or three notes ; the men who carry them behind the paper-scatterer (Fig. 14) simply emit monotonous, protracted sounds through them at intervals. These persons wear a jacket of black linen, which is fastened on the middle of the breast and 


\section{The religious system of China}

vol. I

has along each p.156 side of the opening a broad hem of red colour; moreover, there is on the middle of the breast and on the back a piece of white cloth bearing the inscription hō siú. They wear a low round bat, likewise black, with a small brim. A fringe of red silken threads, fastened on the top, hangs down upon their hat.

These trumpeters remind us of the musicians who, in ancient Rome, marched at the head of funeral trains, each armed with a tuba or tibia longa of about the same length as the performer and ending in a bell-shaped mouth. At their heels follow two dirty blackguard boys, without either uniform, shoes or stockings; each carries over his shoulder a banner of white cloth about one meter by three decimetres, the long side being fastened to a pole (Fig. 14). Of such ts'ái kî or 'decorative flags' there are, as a rule, several in the procession. Most of them are red, because this colour dispels malevolent spirits.

Thanks to all these ingenious arrangements, both the soul and the mortal remains are now pretty well insured along the whole way against the attacks of invisible ghosts. But in several parts of Fuhkien many families consider it advisable to add a third efficacious means for keeping them away : they at intervals explode fire-crackers in the van of the procession. This custom we found to be specially in vogue at Ts'üen-cheu-fu, the capital of the department in which the town of Amoy is situated.

So far for what we may call the vanguard of the procession, which consists exclusively of clearers of the road. The second division opens with two men, in a dress resembling that of the trumpeters, each carrying on a straight pole a great cylindric lantern of paper, the upper part of which is covered with as many flounces of sack-cloth as there are generations of the dead man's family, himself counting for one generation (Fig. 14). Each flounce only partly covers the one underneath, so that they are all visible. On one side these lanterns are inscribed with the official titles and the surname of the dead; the other side displays, in case of a man, the inscription: 'Illustrious father of (e. g.) four generations', in case of a woman : 'Illustrious mother of (e. g.) four generations'. They are called péh ting, 'white lanterns', or moâ ting, 'hempen lanterns'. In this part of the train there are, besides, 


\section{The religious system of China \\ vol. I}

two very big lanterns of p.157 red colour, called kam ting or 'orange lanterns' on account of their resemblance to that fruit. They are suspended from the top of a curved pole and display, in variegated characters, the names and official titles of the deceased.

At the outset lighted candles are placed in all these lanterns ; but they are soon burnt up or blown out by the wind, and nobody troubles himself to light them again. Their use in broad daylight shows decidedly that they are designed to pilot the soul, which lives in complete darkness, along the right path to the burial ground, and we believe that the inscriptions they bear, are intended to prevent the soul from being led astray by other lanterns, which it may happen to see along the road.

The lantern bearers are followed by a band of professional musicians, consisting of six or eight men (Fig. 15). They play the following instruments.

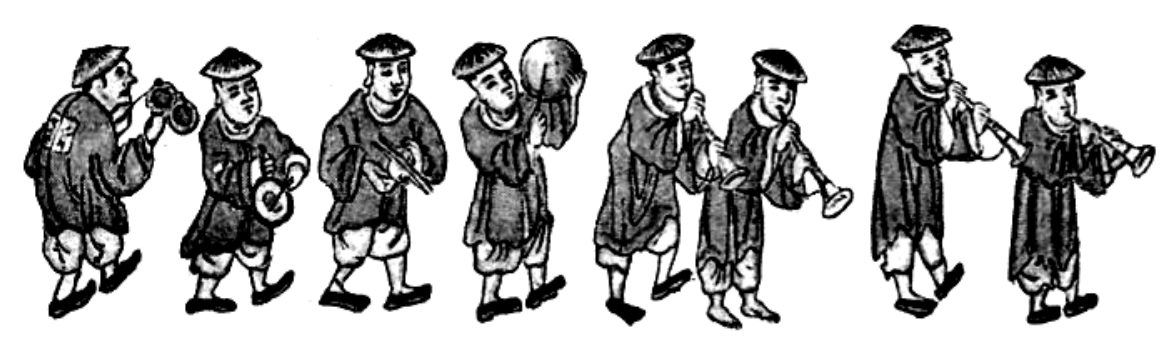

Fig. 15. Band of Musicians in a Funeral Procession.

(From a Chinese Drawing.)

Either two or four wooden clarionets with wide copper mouths and, at the upper end, a flat mouth-piece of reed. One small drum, in most cases carried on a handle which passes through the barrel ; it is beaten by the right hand with a single stick. Very often this instrument is replaced by a small flat drum which has a body of wood covered with buffalo-skin on one side only, and which is likewise beaten with one stick. One pair of cymbals. A small gong with a boss in the middle. A frame in which two little gongs are affixed side by side by means of silk cords; this instrument is carried on a handle and beaten with one stick. The musicians, who always belong to the lowest classes of society, wear hats with red tassels like those described on page 50 ; on their red uniform p.158 coats is stitched, on the middle of the breast and back, a square ornamental piece of white cloth, displaying a painted 


\section{The religious system of China}

vol. I

animal or some other figure. If it is hot, they usually tie their coats like a bundle on their backs and walk along with the upper parts of their bodies quite naked. This band is in many cases accompanied by two trumpeters like those who march in the van of the procession. Quite independent of the music, they send forth from time to time grave and dismal ghost-frightening sounds through the streets.

The music of such bands, of which there are many in the train, is called mourning music, as being quite different from that played on joyful occasions. But we do not believe that European ears would be able to distinguish between the two sorts, because the Chinese do not know major and minor scales and, moreover, the clarionets, which are the only instruments in the band by which more than one single note can be produced, are exceedingly shrieky and never tuned in the same key. The only impression which Chinese funeral music, like their music in general, makes on foreign ears, is that of a noisy confusion of some four or five discordant tones, played by men absolutely ignorant of the principles of harmony, who merely do their utmost to outvie all the other members of the band in making as much noise as possible. From a European point of view it does not even deserve the name of music.

But apart from the quality of this music, we see at any rate that the Chinese observe a custom which has likewise flourished in our Western world since very high antiquity, and which, being faithfully maintained in the burials of princes, grandees and the military, has given birth in modern times to those sublime productions of musical genius, known as funeral marches. Everybody is acquainted with the ancient Christian custom, still surviving in Catholic lands, of conveying the dead to the grave with psalmody. With the Chinese, the use of music in funeral processions and at other important moments of the rites connected with the disposal of the dead, is declared to have for its object the gratifying of the soul of the dead with dulcet tones, but is not intended to increase or decrease the melancholy character of the rites. Sundry passages in the Cheu li show, that the custom of having music in this connection is, in China, as ancient as the remotest ages into which the literature of the empire allows us to penetrate. Describing the functions of a Great Director of Music, the book states that 


\section{The religious system of China}

vol. I

«this dignitary, at Great Funerals, controls the arrangement of the p.159 musical instruments and does so too when, at the interment, those instruments are stored away (147).

Further it says :

«The Master of the Music, at obsequies in general, arranges the instruments of music and then takes the lead of the musical functionaries. He acts in the same manner at the wailing by regular turns $(\underline{148})$.

Still we have the following passages :

«At Great Funerals, the Grandmaster heads the blind musicians and starts the elegy (149). - The clear-sighted musicians start the instruments of music at Great Funerals (150). - At Great Obsequies the Masters of the Pandean Pipes start their instruments, and at the interment they present the same and store them away (in the cave of the tomb) (151). - The Master of the Musical Bells and the Master of the Flutes start their instruments at Great Funerals; they present them and store them away in the grave (152). - The Director of the Instruments of Merit arranges, at Great Funerals, the stands for the bells and for the sonorous stones (153).

The musical band described serves as an escort to a white portable tent or pavilion of wood, open in front and on the two sides; it has a roof of white cloth, linen or silk, on which dragons of gold thread are embroidered and which has a deep fringe on every side (see Plate $X$ ). By means of two large and two small poles it rests on the shoulders of four bearers, of whom one couple walks behind each other in front and the other behind each other at the back. In most cases these men are dressed in the poorest possible way, without the shade of a pretence to uniform dress; they even go half-naked when the weather is hot. On each side, this white pavilion is escorted by a boy, carrying a ts'ái kî which is likewise white ; in addition there is, in some cases, on each side a boy bearing aloft a paper p.160 lantern on a wooden pole. The pavilion contains an image, composed of a hollow frame of bamboo splints covered with variegated paper. (see PI. IX). This is never more than three quarters of a meter high, the dimensions of the pavilion not allowing 


\section{The religious system of China}

vol. I

the use of a larger figure. Its appearance is, according to Chinese conceptions, exceedingly terrific and therefore well fitted to strike the whole

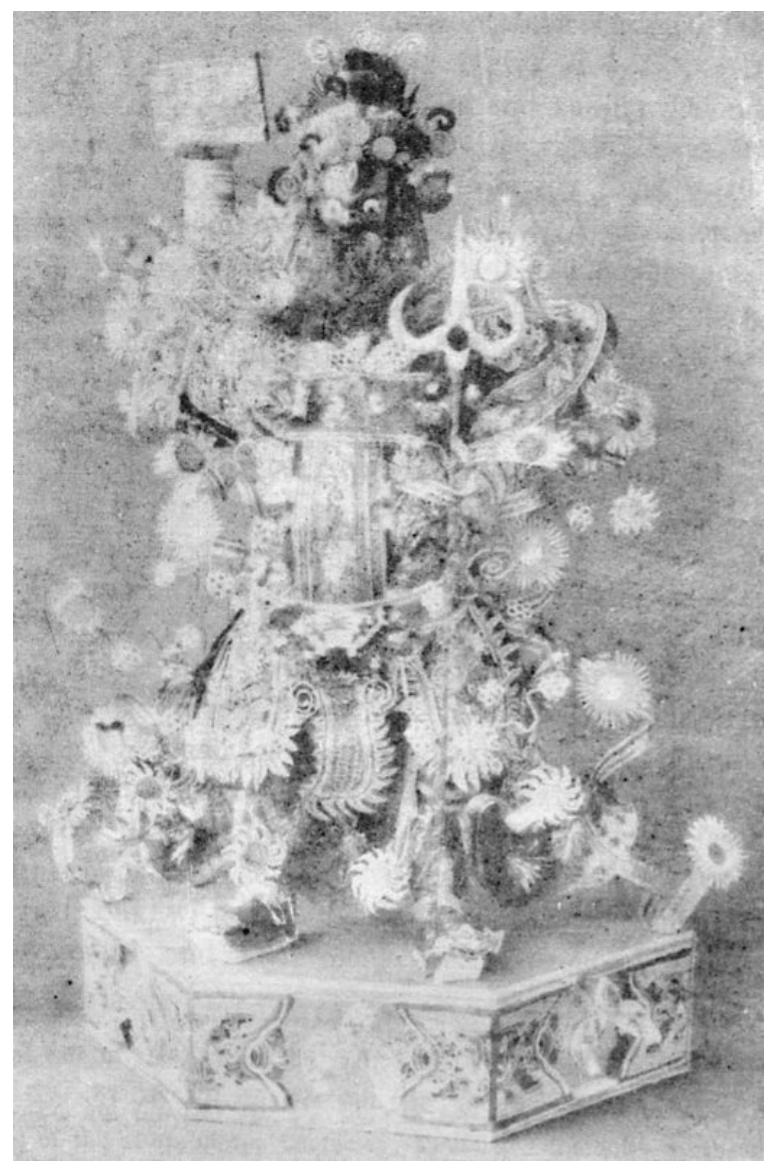

PI. IX The Spirit that clears the way.

host of evil spirits with terror. The face, of a blood-red colour, has two large white eyes, from which black, protruding eye-balls cast about terrible looks ; a third eye stands perpendicular in the middle of the forehead, and a long purple beard of woollen threads heightens the intimidating aspect. The dress is that of a warrior : a helmet covers the head, a coat of mail the breast, thigh-plates the lower limbs. A long red gown hangs down from underneath the armour ; the broad girdle, which encircles the waist, bears the character [], 'King', to make manifest to the evil spirits that they have to do with a being of great importance and power. This image is always made to stand, as an erect attitude renders it more formidable, martial and imposing. Its right hand brandishes a trident, its left hand, which is stretched out aloft, holds a red seal as a token of authority. Variegated ornaments like flowers and stars are affixed to sundry parts of its body. On the whole, the figure is a motley 


\section{The religious system of China}

vol. I

mixture of colours, amongst which, besides gold and green, red, which is so much feared by the spirits of darkness, is most conspicuous.

Although bamboo and paper are the ordinary materials of which such a clearer of the road is made, cloth and inferior sorts of silk sometimes enter into its composition at the burials of the rich. For reasons of economy it has in most cases no back, because this part of the body, if constructed, would be rendered invisible by the back-panel of the pavilion. The name by which this image is generally denoted, reads khai-lō sinn, 'spirit that clears the way'.

In some instances its site is enormous. It is then often wheeled along the road on an open cart, no pavilion being large enough to contain it. When so big, it is usually stuffed with the heart, the liver, the paunch and other intestines of a pig. In Java, where the Chinese inhabitants are nearly all descended from natives of south-eastern Fuhkien, there are frequently to be seen khai-lō sin higher than the roofs of two-storied houses; but in most towns of the southern p.161 provinces of the empire such gigantic figures cannot be used, because the streets are too narrow and, moreover, in most places are covered with bamboo thatch and mats. Mr. Doolittle (154) writes, that in Fuhchow two immense khai-lō sin may sometimes be seen at the burial of high mandarins, the one dressed to represent a civil, the other to represent a military officer.

Chinese authors trace the use of such images at the head of funeral corteges back to the dawn of their national history. The San kiao yuen liu shing ti fuh shwai sheu shen $k{ }^{1}{ }^{1}$, 'Description of Holy Sovereigns, Buddhist Leaders and sundry Divinities of the Source and Branches of the Three Doctrines', says in its $4^{\text {th }}$ chapter :

« The Divine Prince who clears the Road is the Rescuer of the Country mentioned in the Cheu li. A tradition says, when the emperor Hien-

\footnotetext{
1 This interesting collection of biographies of the saints of the Confucian, Taoist and Buddhist pantheon is said to have been written by Yü Pao, in the earlier part of the fourth century. At present no other edition is to be had except an enlarged one published by a certain Jü Lin of this dynasty, in which it is impossible to sift the ancient parts from the modern interpolations. It need not be said that this deprives the work of a great part of the value which it might otherwise claim as a production of antiquity.
} 


\section{The religious system of China \\ vol. I}

yuen (i. e. Hwang-ti, whom chronology places in the $26^{\text {th }}$ century before our era), travelled through the nine provinces of his territory, his chief concubine Lo-tsu died on the road. He then ordered his concubine next in rank, who bore the name of Hao-jü, to take care of the dead body, and this woman bought a Rescuer to watch over the corpse during the night. This is the origin of the divinity in question. His popular name is Spirit of the dangerous Roads; an other appellation runs: General who vociferates along the Roads and the Streets ; a third is : Spiritual Prince who clears the Roads. This divinity is over ten feet high ; his forehead is three feet broad, his beard three feet five inches long and of a red colour. His face is dark blue, his hair is tied in a knot on the top of his head, and he wears a metal hood. He is clad in a red war-tunic and wears black leather boots; his left hand holds a seal of jade, his right a painted halberd with a square blade. When a coffin is carried out with this being in front, all baleful influences are suppressed and malevolent spectres conceal themselves. $\mathrm{He}_{\mathrm{p} .162}$ is the spirit who ensures happiness to coffins that are in motion. This has survived, and has been transmitted as a custom to subsequent generations.

We see from this, that the khai-Iō sîn have their origin in the employment of living individuals as exorcists. This explains why people are still in the habit of placing the intestines of an animal inside the image. The above extract speaks of a Rescuer of the Country, mentioned by the Cheu li. If we open this book, we find indeed a description of the functions of certain exorcists bearing that title; these consequently were actual officers of the state, probably also in the feudal kingdoms, among which the greatest part of the empire was divided in those times.

«It is incumbent on the Rescuer of the Country to cover himself with a bear's skin, to mask himself with four eyes of yellow metal, to put on a black coat and a red skirt, and thus, lance in hand and brandishing a shield, to perform, at the head of a hundred followers, a purification in every season of the year, which means the finding out of (haunted) dwellings and driving away contagious diseases. At royal funerals he walks ahead of the coffin and, arriving at the grave, he leaps into the 


\section{The religious system of China \\ vol. I}

pit to beat the four corners with his lance, in order to drive away the fang-liang spectres (155).

Such a curious devil-dispeller, or perhaps more than one, also figured at the head of imperial funeral corteges during the Han dynasty, as the Books of the After Han dynasty say :

«The Rescuer of the Country has four eyes of yellow metal; he is

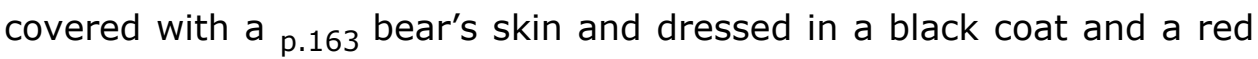
skirt. Bearing a lance and wielding a shield, he stands on a cart drawn by four horses and drives on in the van (156).

Living exorcists at burials are by no means out of fashion in the present age. At Amoy it is still fresh in the memory of the people how at the burial of a gentleman, who had been the prefect of a department in Kiangsi province, four men, clad in fanciful spectral attire, walked in front of a khai-Iō sin of colossal size, dancing and screaming all the way. At the grave they worked themselves into a fit of raving which resembled a demoniacal possession ; they cast themselves by turns into the pit, frantically yelling and brandishing their swords, and thus brought about a general sauve qui peut in the unseen world of spirits. People at that time denoted them by the name of khòng chi'áng, which perhaps means : 'grave-pit hoppers'. Eye-witnesses have told this writer, that it had cost the family much trouble and expense to find persons to act this dangerous part in the burial. Indeed, everybody felt sure that some of the spectres, mad with fear and acting on an impulse of desperate self-defence, might throw themselves upon the exorcists and strike them with illness, nay, with death.

It must be noted by the way that, when the procession is on the point of starting, a petty sacrifice of sweetmeats, cups of tea and such like articles is arranged by the family in front of the khai-lō sinn, and offered to him as a luncheon by one of the attendant relatives, who, holding burning incensesticks in his joined hands, makes a reverence to the image. This ceremony clearly shows that the figure is in point of fact conceived of as being possessed by a soul. Indeed, the Chinese scarcely believe in the existence of any inanimate object. Most families belonging to the middle and lower classes go to no expense for a khai-lō sîn image. They only make use of a pavilion 


\section{The religious system of China}

vol. I

intended for its occupancy, obviously expecting that, though there is no image inside it, the soul of one of the ancients who formerly acted the part of Rescuers of the Country will nevertheless settle in it, or, at any rate, that the spirits of darkness will be intimidated by the mere aspect of the vehicle.

p.164 In a former chapter we have already had an opportunity of stating that scarcely any well-to-do Chinese gentleman neglects to purchase an official degree, wherewith to crown the distinguished position to which his money has raised him (p. 50). After his death, the original imperial brevet of

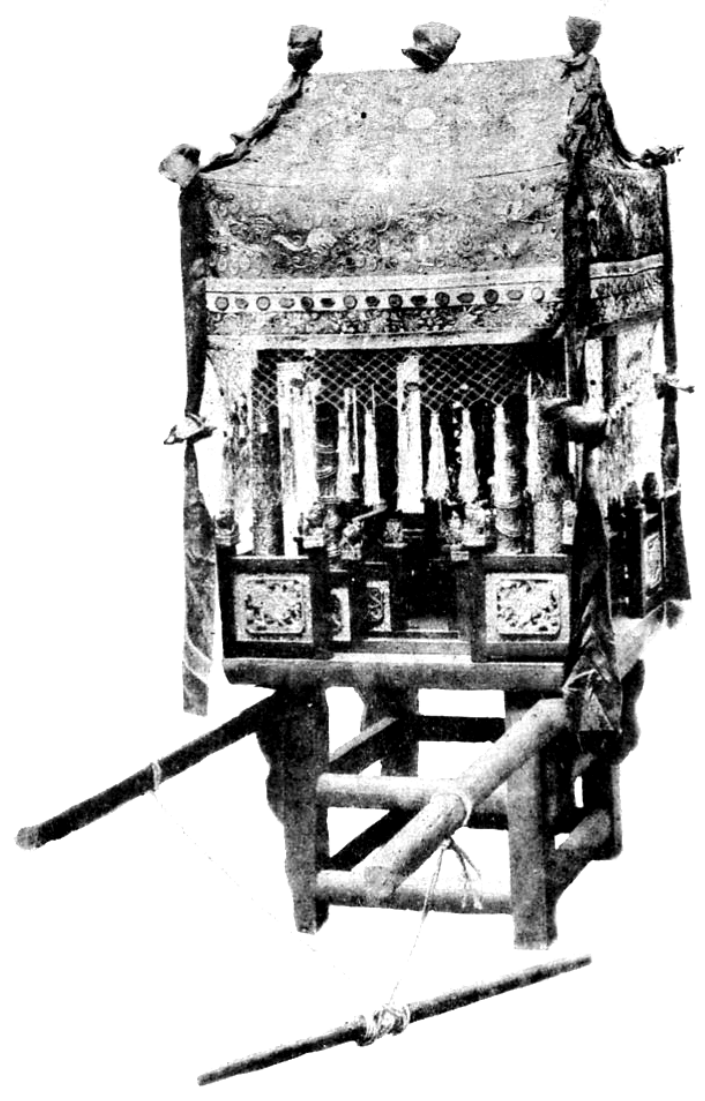

PI. X. Portable Pavilion.

his rank is paraded in his funeral behind the khai-lō sîn : thus men may see how illustrious a personage they have to do with, and evil ghosts, awe struck, keep their distance, The document is rolled up and wrapt in a piece of yellow cloth ; at either end a gilt flower is affixed, and so it is placed over two pins projecting like cloak-pegs from a small wooden stand, which is placed in a pavilion like that represented on Plate $X$. In the present case this pavilion and 


\section{The religious system of China}

vol. I

its embroidered roof are of the imperial yellow colour, in honour of the imperial document which lies inside.

It is quite a matter of course that this khò hong tîng, or 'pavilion for the dignity conferred', should be surrounded with awe inspiring pomp. Everything, in fact, which stands in any relation whatever to the Son of Heaven ought to be attended with becoming respect. A couple of boys, each with a yellow 'decorative flag', walk on the right and left of the pavilion, and a complete band of musicians marches ahead; moreover there is, in front, an escort of attendants and lictors as described on page 87 (Fig. 16). The gongbearers in this case have flags over their shoulders. p.165 In addition there are some

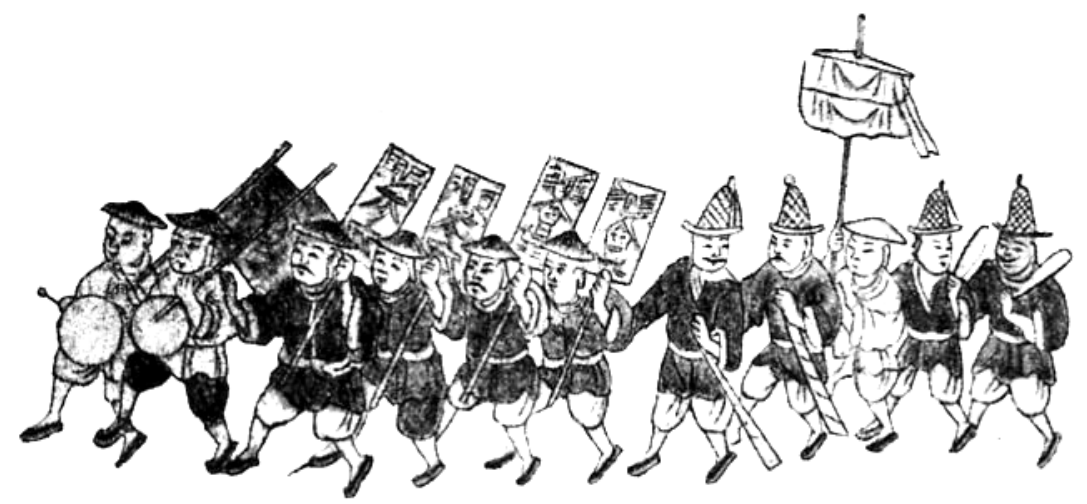

Fig. 16. Escort of official Attendants and Lictors in a Funeral Procession. (From a native Drawing)

men, bearing each a square board on a long wooden handle. Two of these tng-kha pâi, 'tablets with a long leg', display, in raised characters, the official title of the dead ; two others the name of the dignity with which he has been invested during his life ; a third pair bears the words: 'Be respectful and keep silent', and the fourth: 'Turn away and abscond'. The dress of the bearers resembles that of the trumpeters mentioned on page 155 . This party of men are supposed to escort the dead, who is the bearer of the dignity, not the patent, which is merely a badge of it ${ }^{1}$.

1 The above reminds us of our own European practice of exposing the insignia of the orders, which sovereigns have bestowed upon the deceased during his life, upon his catafalque on the way to the grave; if he is a prince or high nobleman, a crown decorates the pall. With the ancient Romans, the metal medals or phaleræ, the torques or decorative rings that were worn on the breast, the coronæ or wreathes, and similar public presents which had been bestowed on the dead, were solemnly carried in his funeral train. Moreover, there was a company of lictors, carrying rods 


\section{The religious system of China}

vol. I

But the principal group in this subdivision of the train, the pride and glory of the mourning family, is a set of two or four literary graduates of the lowest degree, so-called 'Cultivated Talents', siu ts'ai, who have been engaged to act as tsiáng khò-hong tîng or 'directors of the pavilion with the dignity conferred'. It is very grand, in fact the height of fashion, to have such miracles of learning in the train. No wonder they are dressed in the full uniform their rank entitles them to wear, lest anybody should mistake them for ordinary individuals. As long as the procession is passing through inhabited wards, these worthies walk afoot behind the yellow pavilion, most stately and majestic; but when the open country is reached, where not so many eyes are fixed upon them in silent admiration, they immediately betake themselves to the palanquins, designedly posted there by the family for their case and comfort.

Even though the departed has never been invested with an official rank or dignity, a mandarin's retinue may likewise be seen in this part of the procession. The long-legged boards are then borrowed, either gratuitously or for money, from some p.166 relative or acquaintance who, being in reality the bearer of a grade or title, keeps such instruments in his house as a necessary appendix to his dignity. This manner of decking one's deceased parent in borrowed plumes does not in the least shock anybody. On the contrary, every one highly approves of this sort of thing, as the doctrines of filial devotion teach that it is a sacred duty on the part of children and grandchildren to exalt and magnify their seniors as much as is in their power.

A red pavilion with an embroidered cover of the same colour and accompanied by a couple of red decorative flags, appears next in the procession. It contains a shallow slide box of red lacquered wood, which is placed erect on one of its small sides, so that the slide, on which gilt dragons are sculptured, comes in front. A gilt flower is affixed to either side of the box. This is designed as a receptacle for one or more square plates of thick slate stone on which a short necrology of the dead is engraved, and which are

and axes, who were surrounded by all the attributes of the offices and dignities with which the deceased had been invested. 


\section{The religious system of China}

vol. I

to be deposed in the grave ${ }^{1}$. Still for some obscure reason, these stones are not enclosed in the box, but are brought to the grave by a common cooly, who makes his way thither after his own fashion, regardless of the procession. This course of conduct is so generally followed, that the box, which, like all the funeral instruments, is provided by the undertaker, in most instances has not even a side which can be opened, and is merely the imitation of a box. Inside the pavilion one may also see a censer with burning incense, and two tapers in candle-sticks, all likewise destined to be put into the grave. In many cases these implements of worship are conveyed in a special pavilion, which precedes that with the box for the slate stones.

For relations, acquaintances or friends, who wish to give a visible testimony of their sympathy with the mourning family and the deceased, it is customary to enlarge the funeral train with a red pavilion carried by four bearers. In this way they express their willingness to provide the family with the necessary means of carrying the soul and the implements of burial to the tomb ; in other words, each pavilion represents a gift to help the family in defraying the expenses of the obsequies. A piece of inscribed red paper, posted on the back panel, shows who the donor is or the donors are; it expresses this in plain terms, e. $g$. 'The family Wu p.167 allied by marriage', 'The sworn brethern' 2, and the like. Not seldom each pavilion is escorted by a couple of lanterns, carried on poles and bearing the same inscription as the back panel; two boys with decorative flags act as satellites to the pavilion and, in most cases, a band of musicians marches ahead, as another appendage.

These vehicles, which are called tsān tîng, 'auxiliary pavilions', or kheh tîng, 'guest pavilions', remain quite empty, because the family have nothing to put inside. It is scarcely necessary to say, that in funerals of persons of distinction they are often numerous; we have sometimes seen a row of several dozens, The undertakers, who provide them, do not charge much

\footnotetext{
1 They will be dealt with at length.

2 Literally: 'brethren of the golden orchid'. Orchids are in China symbols of sweet harmony, since Confucius has said: "The words of those who are one in heart are fragrant like orchid plants" ; see the Yih king, sect. [], I, 2. Ch. 14 of the imperial edition of 1715 , leaf 4.
} 


\section{The religious system of China}

vol. I

over one dollar or one dollar fifty cents a piece, bearers, musicians, flags and lanterns included, so that the costs do not weigh heavily upon the donors. For the mourning family, however, the case is different, because custom compels them afterwards to repay the attention of all these officious people with a present equal to the outlay they have made. No wonder therefore that the family often see with reluctance such numerous proofs of friendship enforced upon them. At all events the undertaker is the greatest gainer, as this useful man wisely increases his own profits by providing fewer bearers and fewer musicians than have been contracted for. It is easy for him to do this. For, most of the persons who are so intimately connected with the dead as to send a pavilion, are also in duty bound to accompany him to the grave; and, whereas they then walk in the rear of the procession, they cannot see what happens so far ahead of them. But, not liking to be fleeced if he can avoid it, many a donor sends a servant to guard against the rapacious proceedings of the undertaker. This ingenious measure generally entails much clamorous discussion and, occasionally, hot quarrels.

The custom now under notice derives a peculiar interest from the fact that it represents a survival of very remote ages, when it was usual for princes and dignitaries to send horses and carriages p.168 to the obsequies of deceased servants of the state and to those of friends and acquaintances, always adding some pieces of silk, which were to be placed in the tomb with the dead. The $I l i$, after having related how, on the day preceding the burial of an ordinary officer, the corpse was transferred to the ancestral temple and placed there underneath the catafalque in the open court-yard, says, at the outset of chapter 30 (157) :

« The Ruler sends presents, to wit, a bundle of black and scarlet silk and a couple of horses.

The Usher who introduces the visitors leaves the gate, to ask the messenger what he comes for; then he enters again, to announce him. The principal mourner, having laid his mourning staff aside ${ }^{1}$,

\footnotetext{
1 The staff being not only a badge of mourning, but also a symbol of authority, one was not allowed to carry it in the presence of a higher authority, nor in that of a person acting as his substitute.
} 


\section{The religious system of China}

vol. I

receives the visitor outside the gate of the temple, abstaining from wailing. He then precedes him in entering the gate, turns to the left, stations himself with his face to the north, and, together with the other principal mourners, bares the upper part of his body.

The horses now enter and are posted (in the court-yard). The visitor, holding the silk upon his hands, passes by the horses on the west side, places himself near the foremost thill-rope of the catafalque and, with his face turned to the north, delivers his message. The principal mourner thereupon wails, makes reverences, knocks his forehead against the ground and performs a full stamping with his feet. And the visitor, having deposed the silk in the left box of the hearse, leaves the gate.

Passing by the principal mourner on the north side, the steward takes the silk up to bring it eastward, while strong men take hold of the horses and lead them out of the gate. The principal mourner sees the visitor off outside the outer gate, makes reverences to him, re-adjusts his dress and, entering the gate p.169 again, returns to his place, to take his staff in his hands as before.

A visitor who brings presents (from a nobleman or from another officer) is also the bearer of a message. The Usher asks him what the object of his coming is, enters the gate and announces his arrival; then he leaves the gate again, to tell the visitor that he is waited for.

The horses enter the gate and are posted (in the court-yard). The visitor takes the silk upon his hands, the Usher enters the gate first, and the visitor follows him, to acquit himself of his message as in the above case. The principal mourner bows to him from his place, but without stamping his feet ; then the visitor deposes the silk as in the foregoing case, and it is taken up and the horses are accepted as in the above case.

The brothers of the dead are allowed to give presents and to sacrifice ; but acquaintances give presents without sacrificing. 


\section{The religious system of China}

vol. I

These presents consisted likewise of horses and silk. The fact that they are denoted in the $I$ li and all other ancient books by a peculiar character, viz. [], which nowhere occurs in any other sense, certainly points to a custom of established importance at that time and, very likely, also of high antiquity.

Horses were not only presented to the deceased, in order to make them draw the carts loaded with articles and implements that were to be placed in the tomb for the use of the soul, but also to the family, for the transport of carriages and objects that were only to do service in the funeral procession. This follows from chapter 48 of the $L i k i$, which says, on leaf 6 :

« Horses presented to the dead enter the gate of the ancestral temple ; but neither horses presented to the family, nor the additional silk, large white flags nor war-chariots enter that gate (158).

p.170 The Li ki also gives an account of the way in which the messenger of a Ruler acquitted himself of his charge to present horses to a mourning family. It differs slightly from that given by the $I / i$, and runs as follows (ch. 54, I. 32) :

« The principal of the attendants who have to deliver the horses for the dead, takes a long symbol of jade in his hands and delivers his message, saying : "Our Ruler has sent me to present horses to the dead". The assistant hereupon enters the gate to announce the visitor, and then returns to him with this message: "The orphan So-and-so awaits you". The yellow team and the Great carriage are now posted in the central court-yard, the thills to the north, and the visitor, his symbol in his hands, communicates his message, while his followers place the horses on the West side of the carriage. The son having bowed and knocked his head against the ground, the visitor squats down to place the gift on the east side of the encoffined body, at the south corner. It is then taken up by the steward and brought to the east (159).

Contemporary works contain so many passages relative to the custom now under notice, that there is no room for doubt that it anciently prevailed on a most extensive scale. In the Tso ch'wen we read : 


\section{The religious system of China}

vol. I

«In the $23^{\text {rd }}$ year (471 B. C.), in spring, King-tsao of Sung (the mother of the ruler of that state) died. Ki Khang-tszĕ (her grandson) then sent this message : "I possess a couple of poor horses bred by my father, and have ordered Khiu to deliver them to the steward of the lady. May they be used to convey the streamers and ornaments ?" (160)

Chapter 10 of the Li ki (I. 11) relates:

«At the funeral rites for Poh-kao, before the messenger of Confucius had arrived, Jan-tszĕ (a disciple of the sage) took it on himself as his substitute to present a bundle of silk and a team of horses. Confucius said : "Strange, that my disciple makes p.171 me fail in showing my sincerity towards Poh-kao" (161).

And on leaf 21 of the same chapter we read :

«When Confucius went to Wei, he found the mourning rites being celebrated for a man, who had lodged him in bygone days. He entered and wailed for him bitterly. On coming out, he ordered Tszĕ-kung to loose the team of three horses from his carriage and to present them ; but Tszĕ-kung said : "At none of your disciples' funerals has your team ever been taken off ; is it not an exaggeration to do so for a man with whom you merely lodged ?" The Master replied : "A while ago, when I entered there to wail for the man, I found them so entirely overwhelmed with grief that I shed tears. I should be sorry if those tears were not followed by something more. Do so, my child !" (162).

After the auxiliary pavilions comes the last and most important subdivision of the train, in which are the soul, the coffin and the mourners. It opens with a dark-blue pavilion, having a dark-blue roof and, besides a band of musicians, is escorted by two dark-blue decorative flags. It contains a small closet or tabernacle, beautifully carved, painted and gilded, and having folding doors in front; inside this stands the tablet with all its adjuncts as described on page 142. In front of the tabernacle are arranged the 'incenseburner for the ancestors' (p. 143), and two candles, each inside a small lantern to prevent the wind from blowing them out. At the burials of the rich, 


\section{The religious system of China}

vol. I

the censer and the candles, which are respectively designed to gratify the olfactory nerves of the soul that follows behind, and to light it along its way to the grave, are carried apart in a green pavilion, just ahead of that which contains the tablet. Four so-called tsiáng sín-tsú tîng or 'directors of the p.172 pavilion with the tablet' walk in this part of the procession. If practicable, they are sons-in-law or other distant relations of the dead. They are dressed in the mourning prescribed for each special rank of relationship to the deceased.

At the back of the pavilion containing the tablet, outside, at each corner, hangs a white lantern of paper, bearing the inscription: 'Hundreds of sons and thousands of grandsons'. And on the frontside of this vehicle two narrow boards are suspended perpendicularly on the right and left. In characters, neatly carved on a coloured ground, each of these boards bears one line of a distich referring to the soul. As an illustration of Chinese funeral poetry we quote the following specimen of such a distich :

Bestriding a crane, he has already departed for the Western Heaven,

But we have called his soul back to this earth, and it obligingly abides amongst us.

The tablet inside the pavilion is not yet inhabited by the soul. It will be so when, after the completion of the interment, the procession returns homeward from the grave. On the way out, the soul dwells in the temporary tablet or hûn péh, which is placed in the next vehicle. This is a palanquin of state like those in use with official persons, and therefore called tōa kiō, 'great palanquin'; many people also call it hûn kiō or 'sedan-chair of the soul'. The painted portrait of the deceased, which, as we saw on page 113 , is also a seat for his soul, is likewise placed inside this sedan-chair, suspended from the back panel. Four relatives or friends in mourning dress escort the soul in the quality of so-called tsiáng kiō, 'directors of the palanquin', and two 'orange-lanterns', shaped, inscribed and carried like those in the van of the train, are scarcely ever wanting. These move in front, to assist the soul in keeping the right path to the grave. In a great many cases, two white paper lanterns which display in red characters the titles of the deceased, are suspended from the back of the palanquin, at the two outside corners. 


\section{The religious system of China}

vol. I

p.173 If the burial follows quickly on the demise, so that the portrait of the deceased is not yet ready, there is as a rule no state-palanquin. The provisory soul tablet is then placed in the blue pavilion, behind the other tablet, or at the side of it. But if the burial takes place while the great Buddhist mass, already mentioned on several occasions, is in course of celebration, there is then always a palanquin of state in the funeral train. It now contains a socalled hûn sin or 'body for the soul', i. e. a bamboo-and-paper image in which the manes of the dead man reside during that mass in order to receive the homage and the sacrifices of the living, and which in consequence is an object of the greatest attention and solicitude during the long series of days those ceremonies last ${ }^{1}$.

The Buddhist clergymen, who have officiated at the farewell sacrifice ( $p$. 150) and are to continue their salutary work of opening the road for the soul on the way to the grave, march immediately in front of the vehicles described. Their keeping so near the same prevents evil spirits and contrary influences from inserting themselves between them and the soul, and so the effects of the meritorious sacerdotal work cannot be neutralized. A few performers of music are adjoined to the priests, to give a certain solemnity to their ceremonious mutterings.

1 The Chinese custom of having images of the dead in the funeral procession will appear less strange to us, if we bear in mind that a like custom was once widely prevalent in our own western world. A portrait of the deceased in wax or stone was carried immediately in front of the bier by the ancient Romans, in the midst of images or busts of the ancestors, or so-called imagines.

«These practices, says Spencer, look strange to us; but a stranger thing is that we have so soon forgotten the like practices of civilized nations In Monstrelet's Chronicles, Book I, the burial of Charles VI of France is described thus : "Over the coffin was an image of the late king, bearing a rich crown of gold and diamonds and holding two shields, one of gold, the other of silver; the hands had white gloves on, and the fingers were adorned with very precious rings. This image was dressed with cloth of gold, etc. In this state was he solemnly carried to the church of Notre Dame". - This usage was observed in the case of princes also. Speaking of the father of the great Condé, Mme de Motteville says : "The effigy of this prince was attended (servit) for three days, as was customary, forty days having been the original time during which food was supplied to such an effigy at the usual hours". Monstrelet describes a like figure used at the burial of Henry $V$ of England ; and the effigies of many English monarchs, thus honoured at their funerals, are suit preserved in Westminster Abbey, the older having decayed into fragments. - The Principles of Sociology, § 456. 


\section{The religious system of China \\ vol. I}

At the burials of bearers of an official dignity, either purchased p.174 or gained by merit and literary attainments, there is in the train still another

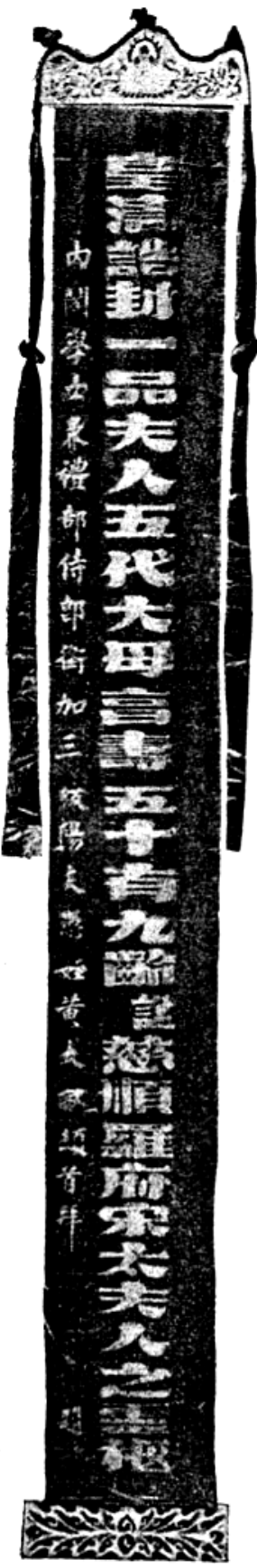
seat for the soul in the shape of a very long streamer or pennon of dark rosy satin, flying from the top of a pole. It is known as ling tsing, 'soul banner' (Fig. 17). It usually varies in length from two to three metres, having a width of from three to four decimetres. At the top it is attached to a small triangular wooden board, which hangs from the top of the pole by means of which the streamer is carried aloft. A decorative strip of blue satin is affixed over the upper rim of this board, in such a way that the ends may hang down a few feet on either side of the streamer and freely flutter about in the wind. To prevent the streamer itself from flying up too high and getting entangled with the surrounding objects, a small painted board of sufficient weight is affixed to its lower extremity.

As in the case of the hûn péh (comp. page 71), the 'soul banner' is rendered fit to be an abode for the soul and so to replace the body enclosed in the coffin, by means of a description of the deceased, which is painted on it in one single column of characters running down the middle from top to bottom. A second column of smaller characters mentions the name, the titles and dignities of the person who, theoretically, wrote the inscription. Here is, for example, the inscription copied by us from the streamer of a prefect of a department, who died in Amoy during our stay in that town :

Fig. 17. Soul Banner.

« Inscribed streamer of Mr. Khiu of the name Yun-lung, on whom the reigning Imperial house of Ts'ing has conferred the title connected with the third degree of rank, as p.175 also the dignity of Prefect of a 


\section{The religious system of China}

vol. I

Department; he was the illustrious father of four generations and has enjoyed a life of seventy-two years.

This is written by Tseng Shi-yuh, his stupid younger brother ${ }^{1}$ in this World of Light, specially invested with the rank of Second Class Secretary of a Board, who in the year kwei-yiu was promoted to the degree which qualifies him for admission to the metropolitan examinations administered by the Board of Rites. He bows his head to the ground.

When any person is invested with an official dignity, his principal consort is, simply in virtue of this promotion of her husband, simultaneously endowed with an honorary title. Accordingly she also has at her obsequies a streamer of the same description. The wife of the aforesaid prefect happening to die shortly after her husband, we had an opportunity of seeing her funeral too. Her streamer was inscribed as follows :

« Animated encoffined corpse of Her accomplished Ladyship of the family Hwang, who bears the posthumous title Kung-kien 2 and was espoused to the house Khiu. On her the Imperial house of Ts'ing has conferred the title connected with the third degree of rank. She was the illustrious mother of four generations and enjoyed a life of sixtyeight years.

This is written by Yang Hiung-fei, her consort's stupid younger brother in this World of Light, who is specially endowed with the dignity of Second Class Secretary of a Board and entitled to compete at the metropolitan examinations conducted by the Board of Rites. He bows his forehead to the ground.

p.176 The characters on such streamers have the square form generally used in printing, or, in other words, they are the so-called pien tszĕ, 'flat or low characters', or Sung thi tszĕ, 'characters of the shape in vogue during the

\footnotetext{
${ }^{1}$ In China, everybody calls his friend his elder brother and styles himself the younger brother of his friend.

2 Mary deceased ladies and gentlemen are, after their death, denoted by another name, because that by which they were distinguished during life is then too sacred to be pronounced. More particulars on the custom of avoiding names will be given in our Second Book.
} 


\section{The religious system of China}

vol. I

Sung dynasty'. They are painted on the silk with a yellow water-colour in which some glue is mixed to fix it ; in a few cases the whole inscription is gilt, which looks very pretty on the pink ground.

It would be a mistake to suppose that such a soul banner is merely a symbolic representation of the deceased. On the contrary, it is actually the soul, or, at any rate, the streamer and the manes of the dead person are most intimately fused into one. At the interment it is placed in the tomb upon the lid of the coffin, and thus the soul is made to establish itself in the grave, from whence it is expected henceforward to issue blessings of every kind to the offspring. The part which the streamer performs in the obsequies being of so much importance, it is natural that in every respect it becomes an object of great solicitude. It is written by a person invested with an official rank, the higher the better, because in this way the soul, which it harbours, is surrounded, nay infused, with influences which cannot fail to endow it with the capacity to help to high official dignities from out of its tomb. But this end is attained all the same if the grandee merely writes the banner in theory, that is to say, if his illustrious name and his titles only figure on it as if he had actually written it. Accordingly, the relations simply ask his permission to use his name for the purpose, and then the streamer is inscribed by an ordinary workman, or by some clever member of their own family. A grandee will scarcely ever refuse to lend his name and titles for a funereal streamer when a fashionable family applies to him, because he knows custom requires that he should be liberally rewarded for his kind permission when the burial is over.

To increase the power of the streamer for ensuring titles and dignities to the offspring, it is nominally carried to the tomb by a military mandarin, either titular or in active service. This grandee appears in the procession on horseback, in the rear of the customary cortege of lictors, servants and bearers of title-boards; and if he is actually in the service of the State, he is generally escorted by a certain number of soldiers with matchlocks, swords and other p.177 weapons of every description, in many instances with bows and arrows. In everybody's eyes this cortege adds great dignity to the obsequies and, of course, the family are very proud of it. Civil mandarins are never engaged to act as bearers of a soul banner. For, these worthies cannot 


\section{The religious system of China \\ vol. I}

ride on horseback ; they scarcely ever use any other means of locomotion than a covered palanquin, and a man sitting in such a vehicle cannot possibly carry a long object like a streamer on a staff.

We have said that the streamer is only nominally carried by the mandarin. In fact, the work is actually done by a servant in a kind of uniform, or even by a dirty cooly who walks on foot behind Rozinante, winding, for convenience's sake, the streamer carelessly round the pole. The practical effect which the streamer is expected to have on the glory of the offspring, is not in the least diminished by this measure which eases the great man on horseback of a troublesome burden.

The soul banner derives a peculiar interest from the fact that it represents an institution of very ancient times and, like the hûn péh, which is only another form of it, has played an important part in the ancestral rites of the ruling classes in ages as far back as the Cheu dynasty. Since it would carry us too far from our present purpose to enter now into the historical origin of these two interesting objects, we defer dealing with them till our Second Book, a part of which will be specially devoted to the different sorts of seats which the Chinese are, or formerly were, in the habit of providing for the disembodied souls of their parents and ancestors.

Finally we come to the rear of the procession, which consists of the coffin and its attendant mourners, musicians and others. Two youthful male relations of the family, dressed in white mourning, come first, each with an oblong piece of white linen, suspended from the top of a pole like a banner and inscribed with the characters [][], 'linen of which mourning clothes of the third and fourth degree are made'. We read in the $I$ li that, when the coffin of an officer had to be removed for burial, and to this end was taken out of the shed wherein it had been stored away for a time (see p. 99),

« the Invoker after the manner of the Shang dynasty, having bared his head and the upper part of his body, entered the gate with a cloth of linen of which mourning clothes of the third and fourth degree were made, and ascended the western steps to their top; there, without going up to the hall, he cried three times to the soul, and exclaimed thrice : "Open p.178 the shed !", finally ordering the mourners to wail... 


\section{The religious system of China}

vol. I

Subsequently he wiped over the coffin with the cloth and covered the latter with a corpse-pall (163).

And describing the arrangements for the funeral procession, the $I$ li says :

« The Invoker after the manner of the Shang dynasty holds the cloth of mourning material in his hands, using it to direct the movements of the coffin (164).

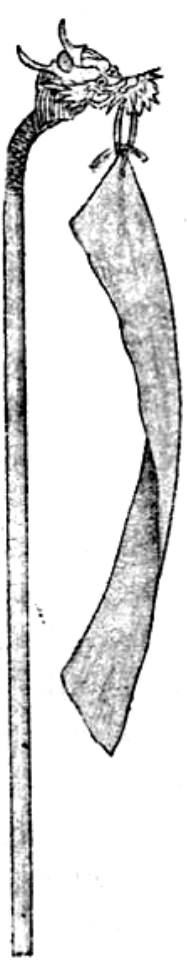

He placed himself, adds Ching Khang-ch'ing, in front of the coffin, and all the way gave signals to the men who drew the catafalque.

Fig. 18 is a reproduction of the picture which the Khienlung editors of the $I I i$ (ch. 44) and the Li ki (ch. 82) give of the cloth in question ${ }^{1}$. The Amoy Chinese of the present day, evidently misled by the accidental circumstance that the characters [][] also mean 'dissemination of merit', seem to consider the ancient cloth as having been a kind of honorary banner signalizing the virtues of the deceased. This is apparent from the fact that the corresponding pieces of linen, which they use at their burials, bear the two characters as conspicuously as possible, while in addition two similar banners are carried behind the first, inscribed, in the case of a man, with the binomium [][], 'faithful and devoted', and in that of a woman, with [][], p.179 'chastity and submission' viz. to her husband.

Fig. 18. Banner of

These two banners are likewise carried by two boys in mourning. Mourning Linen.

\footnotetext{
1 They have evidently borrowed it from the 'Illustrations fur the Three Rituals' Sam Ii thu, the work of Nieh Ch'ung-i, a renowned scholar. This author presented the manuscript in 962 to the first emperor of the Sung dynasty and it was adopted as a standard authority for the state religion during that dynasty. Nieh's book was compiled from divers works of the same character, in existence at the time, one of which dates from the Sui dynasty; but we do not know whether any of these writings are still extant.

The second-hand pictures, which the San li thu contains, accordingly are for a great part pretty old, and this increases the probability that they represent objects and instruments as they were in pre-christian times. A biography of Nieh with particulars of his works is to be found in ch. 431 of the History of the Sung dynasty. The chapters of the San li thu on matters relating to mourning and funeral rites have been reprinted in the $K u$ kin thu shu tsih ch'ing, the renowned giant thesaurus already mentioned on page 75.
} 


\section{The religious system of China}

vol. I

A band of eight musicians comes next. They play a gong, a drum, a pair of cymbals and, instead of the detestably discordant clarionets, two or three stringed instruments and a flute. Four so-called tsiáng pán or 'managers of the coffin', being kinsmen or friends of the family in white garments, walk immediately in front of the bier, which is, as their title indicates, intrusted to their care. In many parts of southern Fuhkien, and sometimes in Amoy also, these men and the musicians ahead of them are preceded by either two or four bearers of long torches of bamboo splints drenched with oil or other combustible matter, designed, like the lanterns at the head of the procession, to light the spirit of the dead along the road. If the torch-bearers are members of the family, they are dressed in a mourning attire ; but when common coolies are hired for this work, a simple band of white cloth is tied around their foreheads. Torches are also used in Chinese funerals in the isle of Borneo, amongst immigrants from the department of Ch'ao-cheu-fu, which is a part of Kwangtung province ${ }^{1}$.

The coffin follows immediately behind the four tsiáng pán. The manner in which corpses generally are conveyed to the tomb and the instruments used therefore are easily described. As may be seen from the first figure of Plate $X I$, which represents the catafalque without the drapery that generally covers it, the coffin is placed on a strong oblong frame of wood, which is strengthened by some extra bars inserted athwart, and accordingly looks like this figure : $[\bar{\square}]$. When this bier has been placed on a couple of trestles (see p. 145), and the coffin arranged lengthwise upon it, p.180 a triangular frame of wood is inserted upright in the middle of each long bar of the bier, in two holes made there for the purpose. Across the lid, through the tops of these two triangles, which reach a little over the coffin, is then passed a strong piece of wood ; finally, on either side of the coffin, a strong rope passing over this cross-beam is tied firmly to the bier on the right and left of each triangle,

\footnotetext{
1 It may here be observed that the ancient Romans never solemnized funerals without the addition of torches, and that with the Greeks the first man in the procession most likely bore a lighted torch, which was after a time passed to the person following behind him, and so on, till everybody had carried it for a few moments. We need scarcely say that in the Christian world too the use of torches and tapers in obsequies is of very old standing, and that with many savage and semi-civilized tribes in various parts of the globe torches are carried in funeral processions.
} 


\section{The religious system of China}

vol. I

so that all the different pieces of the catafalque are held tightly together and cannot be dislocated unless the ropes are removed or snap off.

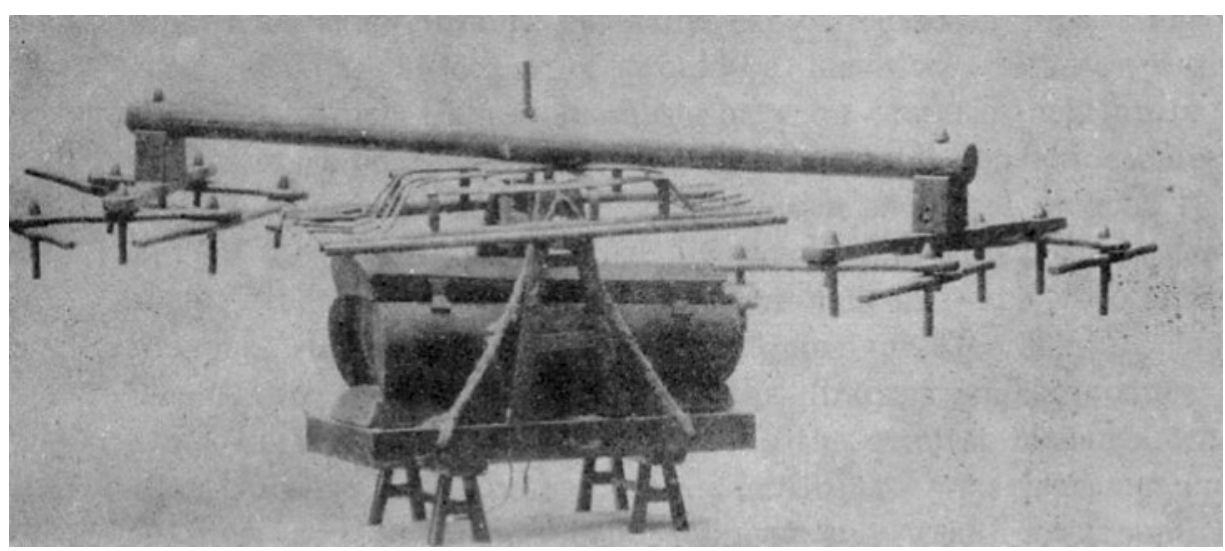

PI. XI . Catafalque without the drapery.

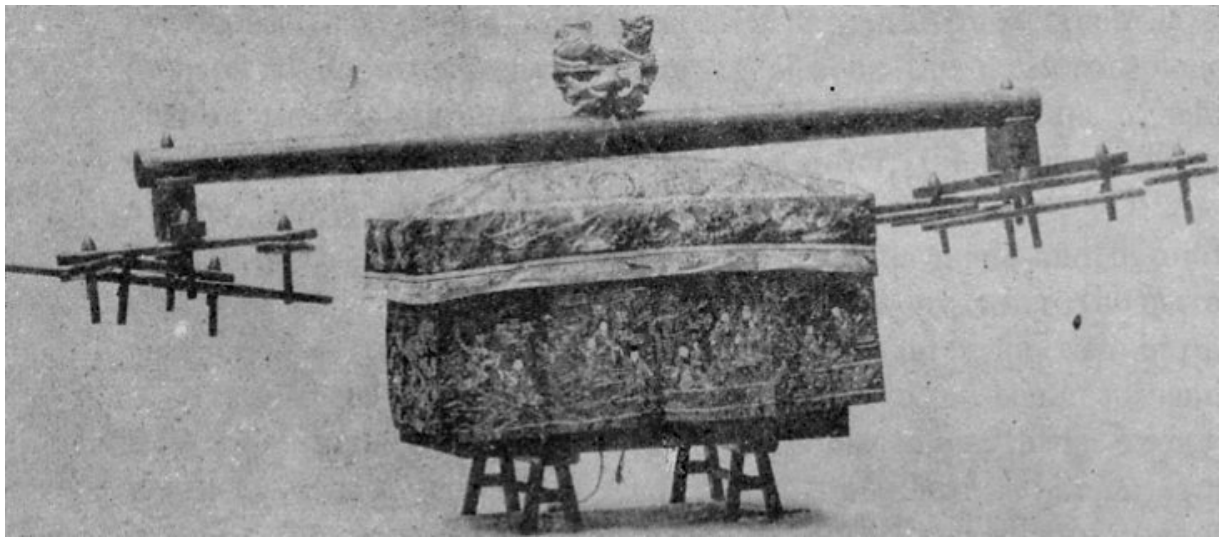

Catafalque with the drapery.

Over this bier, which is popularly styled a ch'ia or 'carriage', a large rafter, called 'big ox' tōa gû, or 'big dragon' toā lîng, is made fast by means of an iron bolt, which passes loosely through a hole in the middle of the rafter and the center of the cross beam mentioned above. It will be clear now that, when the coffin bearers take the rafter upon their shoulders, the whole catafalque hangs down and can turn on the bolt as on a pivot. This is of great advantage in carrying the cumbersome burden through the narrow alleys which in Chinese towns bear the name of streets; otherwise short corners could never be turned. With the better classes, the coffin and hearse are generally so bulky and weighty that a good number of men are required to move them. Therefore, at each end of the rafter a cross pole is contrived by 


\section{The religious system of China}

vol. I

means of a loose bolt of iron or wood, so that there is room for four bearers, one at each end of these poles. This number can be doubled by fixing to each end of the two cross poles another cross pole in a corresponding manner, and so on. Thirty-two may be said to be the largest number of bearers ever employed in Fuhkien; even sixteen are rare, eight being the usual number, also with the well-to-do. A desire to make a show is as often an element in determining the number of bearers as the weight of the coffin itself.

No family, not even the poorest, will ever send a kinsman to the grave without having the coffin concealed on the road thither by means of a socalled koan tà or 'coffin cover'. As the first figure on Plate XI shows, a rough frame of bamboo is placed over the lid, underneath the rafter. Over this frame is cast a sort of roof-like awning, consisting in most cases of drapery, sometimes of silk; further, a piece of the same material is suspended by tapes p.181 from each of the four sides of the frame, so that the coffin is entirely hidden from view. In the case of a male person the koan tà is red, in that of a woman it is dark blue. On all sides it is beautifully embroidered with figures of gold thread and variegated silk. The side curtains generally exhibit episodes illustrating the most striking historical or would-be historical instances of filial devotion, which Chinese moralists have for centuries held up to the nation as standard examples and models for all generations present and to come. On the front curtain are a couple of dragons rising out of the waves, surrounded by clouds and with a sun between them; the back displays a tiger or unicorn, the top exhibits dragons, sundry ornamental flowers, and figures representing clouds. Thanks to these clouds and to the dragons which produce the same in their quality of watergods, the greatest blessings which the Universe can bestow, viz. fertilizing rains causing crops to grow and so giving food, raiment and wealth, surround the dead, and he may avail himself of those blessing for dissemination among his descendants from out the tomb. The unicorn enables the dead man to cause famous persons to be born into the family, for, since this fabulous animal made its appearance at the birth of Confucius, its image can bring about the birth of sages and of men destined to everlasting renown. And as to the tiger, its portrait keeps evil spirits away from the coffin, all Chinamen being convinced that ghosts 


\section{The religious system of China}

vol. I

and demons fear nothing so much as this monster ${ }^{1}$. For this reason there is also on the most conspicuous part of the catafalque, viz. over the great bolt by means of which the latter is suspended underneath the rafter, the wooden effigy of a tiger, nicely gilded and painted.

The catafalques are not everywhere in China made and decorated after the same plan. In many parts of the empire, where the narrowness of the streets is no impediment, they are, for rich burials, of a size bordering on the gigantic. Instead of being suspended from one single pole, the coffin is then placed lengthwise upon two parallel rafters, which at the same time bear a huge square canopy, the corners of which are elegantly turned up after the well known Chinese house-roof fashion. Underneath this canopy embroidered screens of drapery hang down along the sides of the coffin, which in this way is rendered invisible, while other p.182 pieces of drapery are affixed to the rafters, so as nearly to reach the pavement when the catafalque stands still. A catafalque of this description may have a length of over three metres with an equal height, reckoning from the tiger at the top of the canopy; it is carried by means of a similar system of poles and cross-poles as has been described above, and often requires thirty-two or even sixty-four bearers. Catafalques of various sizes and styles fall between the ones described and those used in Amoy by the very poor, who merely have a rafter tied lengthwise over the lid by ropes passing underneath the bottom of the coffin, with some pieces of coarse drapery carelessly thrown over it.

But, however much their shapes may differ in the several parts of the empire and for the sundry classes of society, they are all decided imitations of the wheeled catafalques, which tradition and some passages in the ancient works on ritual teach us were in use for the Rulers, nobles and officials during the oldest historical period of the empire. Chapter 58 of the Li ki says on leaf 39 :

«In decorating a coffin they use, for a Ruler, side curtains with dragons depicted on them, three rain catchers with moving streamers, further a roof with figures of axe heads and showing three flames side

\footnotetext{
1 The reasons for this will be explained in our Second Book, in the chapters on Demonology.
} 


\section{The religious system of China}

vol. I

by side, as also three figures ${ }_{\xi}$ arranged side by side. There is also a tent-like cover of plain tapestry (placed immediately over the coffin), and over this comes a false roof. The scarlet strings (for connecting the roof with the curtains) are six in number. The top of the roof is composed of material of five different colours, and decorated with five cowries. There are, moreover, two shah with the figure of an axe depicted on them, two with the figure $\xi_{5}$ and two painted (with clouds); all of them are surmounted each by sceptres of stone. The fishes jump and wave the rain-catchers to and fro. For a Ruler there are also six scarlet cords to tie the ropes of the coffin to the catafalque, with six scarlet ends drawn through the side curtains (165).

Fig. 19a. Ancient Catafalque for the Ruler of a State.

In translating this
passage we have closely

followed the interpretation of Ching Khang-ch'ing, who, standing nearer to the Cheu p.183 dynasty than any expounder of the $L i k i$, has generally been recognized by all as a standard authority. This renowned scholar explains the rain-catchers as a sort of bamboo trays covered with blue cloth, which were suspended under the roof to represent the gutters that, on the houses

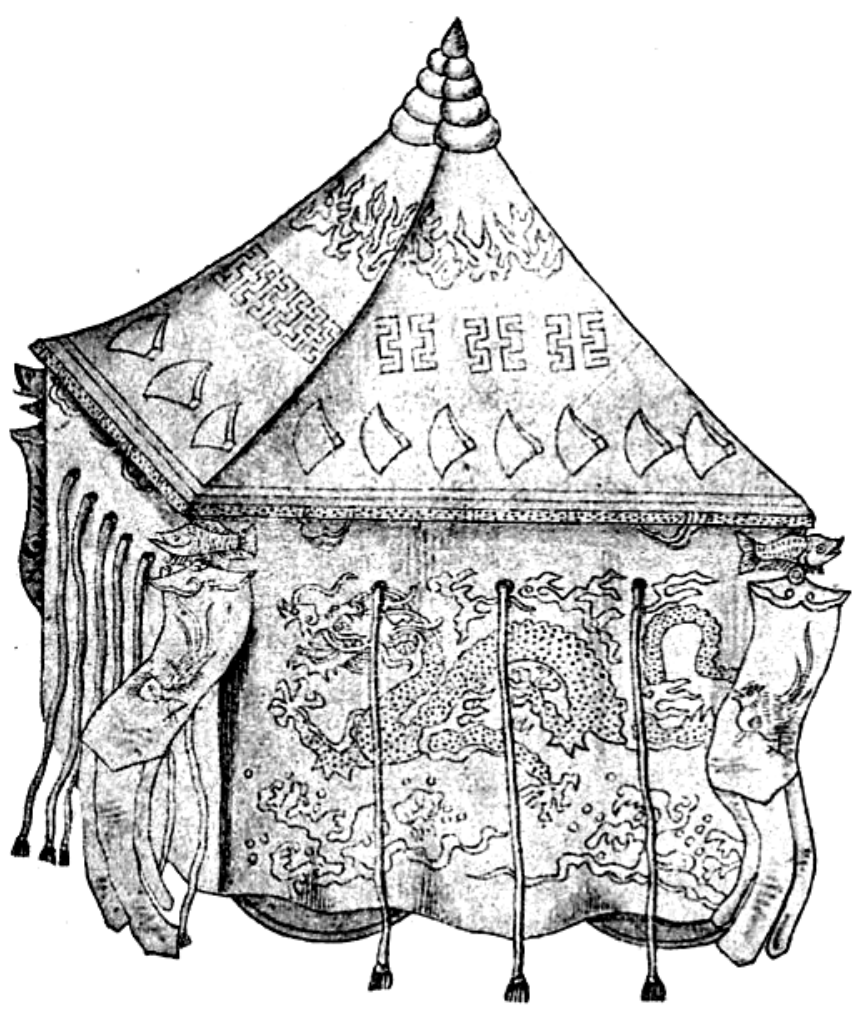
of the living, catch the rain from the caves ; in fact, says he, the catafalque represented for the dead man the dwelling he occupied during his life. A copper fish was suspended underneath each tray, and under each fish hung a moving streamer, upon which, according to the commentators, a pheasant was depicted. Such things were, however, not suspended on the catafalque of 


\section{The religious system of China}

vol. I

a Great officer, as may be inferred from chapter 53 of the Li ki (I. 28), where it is said :

« For a Great officer yellowish blue pendants are not affixed underneath the water-catchers.

A picture of such a princely catafalque, as the editors, relying on tradition in connexion with the above interpretation by Ching Khang-ch'ing believe it to have been, is to be found in the Khienlung edition of both the $L i k i$ and the Cheu li, respectively in ch. 82 and ch. 48. Fig. 19a is a reproduction of it on a smaller scale. About the catafalque of p.184 official persons of lower rank than a Ruler the $L i$ ki relates, also on the $39^{\text {th }}$ leaf of ch. 58 :

« For a Great officer they use side curtains painted (with clouds), two rain-catchers without moving streamers, a roof painted with clouds, with three flames side by side, and three figures $\xi^{2}$ arranged side by side. There is also a tent-like cover of plain tapestry, two scarlet and two black strings (for connecting the roof and the side curtains). The top of the catafalque is of tri-coloured material and ornamented with three cowries. There are two shah with the $\xi^{5}$ figure, and two shah painted with clouds, each of them surmounted by yak tails. The fishes jump and wave the rain-catchers to and fro. And in the case of a Great officer, the cords which tie the ropes of the coffin to the catafalque are, when placed towards the front of the catafalque, scarlet, and at the back they are black, and the same is the case with the ends drawn through the side curtains.

For an ordinary officer they use side curtains of (undyed) cloth and a roof of the same material, further one rain-catcher with yellowish blue pendant, two scarlet and two black strings. The top of the roof is of tricoloured material and ornamented with one cowry. There are two shah painted with clouds, and each is surmounted by yak tails. In the case of an officer, the cords which connect the ropes of the coffin with the catafalque are, when placed towards the front, scarlet, while those at the back are black; and the two ends which pass through the side curtains are scarlet (166). 


\section{The religious system of China \\ vol. I}

Fig. $19 \mathrm{~b}$ is a reproduction on a reduced scale of a picture which ch. 44 of the $I$ li gives of such a catafalque of an ordinary officer. The above quotations, which it illustrates, sufficiently prove that we are perfectly justified in suggesting, that the modern catafalques are imitations of those of ancient China. Besides the p.185 catafalques, the shah which, according to the above extracts, were used in the burials of grandees, have survived till the present day. It is not exactly known what their shape was in the time of the $L i k i$, but we may learn from Ching Khang-ch'ing how they looked in his time, to wit, during the Han dynasty; and as this house no doubt borrowed them from the more ancient dynasties, there are grounds for believing that Ching's description also holds good to a great extent for the shah of the house of Cheu. He says :

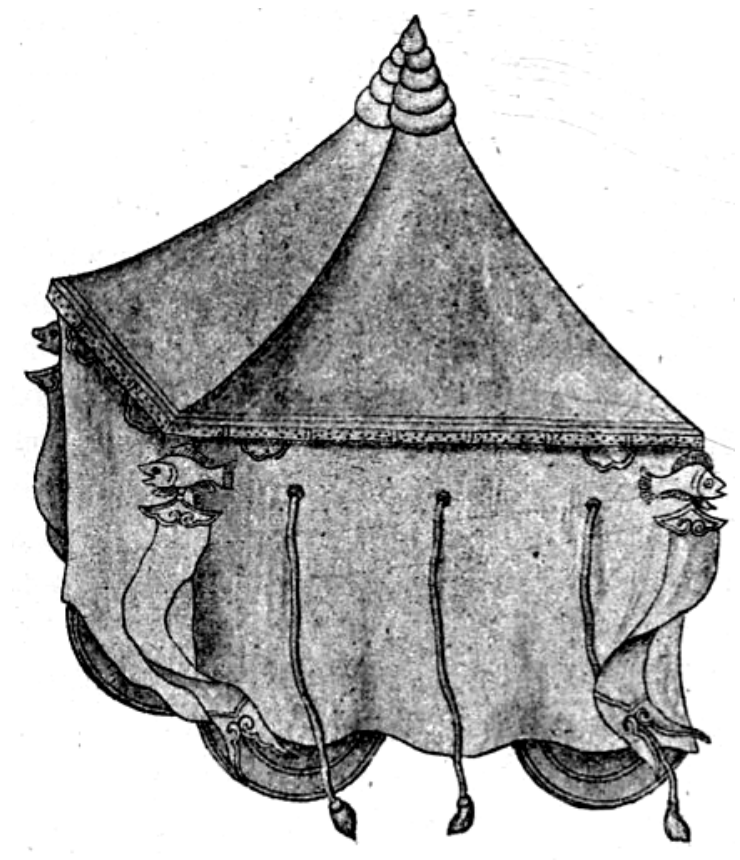

Fig. 19b. Ancient Catafalque for an ordinary Officer. «A shah consists of a frame made of wood, three feet broad by two feet four inches high ; it is square, has raised corners and is covered with white linen. As to the figures painted on them, they represent clouds and for the rest they exhibit the respective insignia of the person for whom they are made. The handle is five feet long. When the funeral car moves on, men are employed to carry them behind it, and when the coffin has been lowered into the grave, they are planted inside the pit (167).

That this description holds good, at least on some points, for the shah of the Cheu dynasty also, may be inferred from the fact that the Cheu li contains the following passages :

« When there is a funeral, the tailor sheathes the woodwork of the p.186 shah (168). 


\section{The religious system of China \\ vol. I}

«At the funeral of an empress, the female attendants hold the shah (169).

The reader will have recognized already in these shah the forerunners of the square boards inscribed with the titles and dignities, and fixed on the top of long handles, which are now carried in the retinue of mandarins whenever they appear in public, and, at the death of a titled person, in his funeral procession (comp. p. 165). The part they played in the obsequies of antiquity sufficiently accounts for the reason why even at the present day people are most partial to having them in the burial train of their dead : as we have said, if the dead man be not Fig. 20. A Shah. entitled to have them himself, the family will borrow them for the purpose from titled friends or from mandarins with whom they are acquainted. As these socalled 'long-legged boards' or tng kha pâi do now, so the

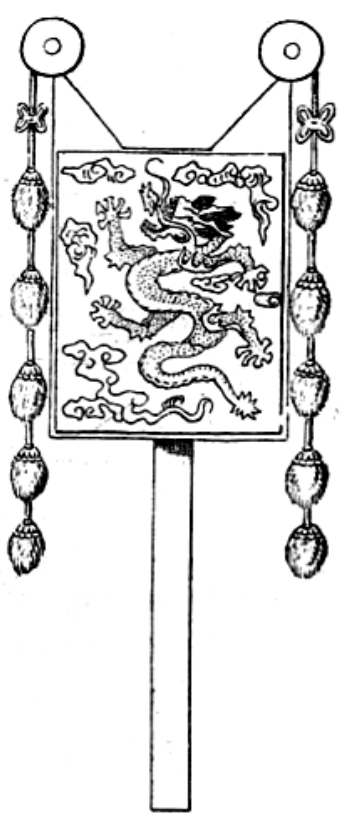
shah formerly displayed the rank of the grandee, though not by characters, but by emblematical figures. Apart from the testimony of Ching Khang-ch'ing, who explicitly states this in the passage just quoted, it is proved by the yak tails suspended over them, these objects being in ancient times symbols of official dignity. Moreover, the number of shah was increased in proportion to the rank of the person, as is proved by chapter 34 of the Li ki, which has on I. 13 :

«In some ceremonial usages the quantity of things forms the mark of distinction : the Son of Heaven has eight shah, a feudal prince six, a Great officer four.

The symbolic meaning of the axe-heads and ${ } \xi^{2}$ figures depicted on them is not clear; the clouds which, as we have seen, also decorated the ancient catafalques and are still found on the modern ones, may have represented the blessings of the dragon or rain-god, which has from time immemorial been an emblem of a blissful government represented by the emperor and by the officials as his deputies. 


\section{The religious system of China}

vol. I

The Khienlung editors of the Three Rituals suggest that the two shah which, according to the above citation from the $L i k i$, the Son of Heaven had in addition to the six of a feudal prince, were painted with a dragon, the characteristic symbol of the imperial p.187 dignity. Now recapitulating what is contained in the several extracts quoted on the foregoing pages about the shah, we see that :

an ordinary officer had one pair, painted with clouds,

a Great officer two pairs, with clouds and 张 figures respectively,

a feudal prince three pairs, with clouds, $\xi$ figures and head-axes respectively,

the emperor four pairs, with clouds, 张 figures, head-axes and dragons respectively.

The Khienlung edition of the Li ki (ch. 82) and that of the Cheu li (ch. 48) give a picture of each of the four sorts. As they are all shaped alike, the emblematical figures alone differing, we confine ourselves to reproducing in Fig. 20 the one with a dragon. The pendants hanging down from the two circular sceptres of stone, which surmounted the top of each shah, consisted of feathered ornaments ; for this reason, perhaps, the element [a], feathers, enters into the composition of the written form of the word shah, which is $[a b]$.

To return now to the catafalques : those of antiquity were, like those of modern times, moved forward by a large number of men. In ch. 56 of the Li ki we read, on leaf 17 :

«When they go up to the ancestral temple ${ }^{1}$ and there put the coffin in its place, the ropes attached to the carriage of the bier for drawing it forth are, in the case of a feudal prince, grasped by five hundred men. The men at these four ropes are all gagged. The Minister of War holds the clapper. He has eight men on his left and eight on his right (to shout out his orders). The chief of the artisans directs the movements of the coffin by means of a bundle of feathers, suspended

1 There the coffin must remain during the day previous to the burial : comp. page 151. 


\section{The religious system of China \\ vol. I}

from the top of a pole. And at the obsequies for a Great officer, when they go up to the ancestral temple and there put the coffin in its place, three hundred people grasp the ropes for drawing the coffin. The man with the p.188 clapper has then four men on either side, and the movements of the coffin are guided by means of alang grass (170).

The curious custom of gagging the men put to the carriage of the bier naturally points to a prevailing custom of loudly vociferating while conveying the coffin forward, a custom which was disliked by the higher classes. Chen Hao of the Yuen dynasty, commenting on the passage just quoted, describes such a gag as being «something like a chopstick, which was tied in the mouth by means of two cords attached to either end and knotted together behind the neck». The use of these instruments seems to have been pretty common in ancient China, as ch. 37 of the Cheu li (I. 44) describes the functions of a certain 'Officer of mouth-gags', on whom it was incumbent to stop tumultuous cries at the great sacrifices of a state, to have clamorous people gagged during military reviews and great hunting parties, and to forbid all vociferation in the capital.

On the meaning of this crying while conveying a coffin to the grave, some light is thrown by the Historical Books of the Tsin dynasty.

«It was an ancient institution during the Han and Wei dynasties that the men, who in Great (i. e. imperial) funerals and in funerals of high ministers held the drawing-ropes, chanted while pulling forth the carriage of the bier. When projecting new rites (for the house of Tsin), the framers acted on the supposition that such singing had taken its origin from the songs, by which serfs and bondsmen employed in the case of the emperor Wu (B. C. 140-87) of the Han dynasty had, during their toilsome labour, given vent to their deep sorrow, such songs having thereupon been adopted as a rite on accompanying the dead to the grave. The projectors of the said new rites also took into consideration that, though the songs might serve to soothe sorrow, yet they were not mentioned in the Classics, so that it had been an infringement upon the Rites to allot ${ }_{\text {p. } 189}$ such singing a place among the statutory rituals ; - further, they considered that, in using mouth- 


\section{The religious system of China \\ vol. I}

gags, the object was merely to produce a bawling noise as a mark of affection, and that it was an improper thing to have songs for the sake of show. Therefore they abolished all chanting at the side of the bier. But (the statesman) Chi Yü ( $3^{\text {rd }}$ cent.) gave it as his opinion with regard to the singing at the bier-ropes that, though melodious songs tended indeed towards dispelling sadness, gags held in the mouth carried the grief up to its highest pitch ; further, he pretended they had the good effect of making an impression on the multitude. Moreover he stated that, though such singing is not mentioned in the Classics, yet it represented an ancient institution maintained by a series of dynasties. He showed that the Shi king mentions a man of higher order singing to give vent to his sorrow ${ }^{1}$, and he demonstrated in the end that having chants for the sake of show is beyond the reach of all blame. His conclusion therefore was that the new rites should not differ on this point from those of former times, and his advice was followed by imperial edict (171).

A careful perusal of this extract will show that the gags in question were used with the object of changing, in burials of the highest official classes, the customary singing into a wailing hubbub or monotonous bowling, which moralists considered to be more in harmony with the mournful character of a funeral procession. But the opinion of the first compilers of the rites of the Tsin dynasty as to the origin of this chanting and crying, must be accepted with great reserve. For supposing their assertion that it took its rise during the Han dynasty were true, how then are we to account for the fact that the Li ki already makes mention of gagged catafalque-drawers ? p.190 This naturally suggests the prevalence of the custom in question in much earlier times. It does not appear improbable that it simply originated in the ancient practice of calling back the soul by chanting death-dirges and expostulating with it in terms of reproach and grief, in short, in the death-howl already referred to on page 10 seq. and which we shall treat exhaustively in the first chapter of the next part of this Book. This view is confirmed by the fact revealed in the $\mathrm{Li}$ Ki that, in ancient times, the men who drew the catafalque

\footnotetext{
1 This is so in point of fact. See the last line of the Siao min section.
} 


\section{The religious system of China}

vol. I

to the tomb were those who resorted to the mortuary house to offer condolences, persons, in fact, closely allied to the family by ties of blood or friendship, so that wailing was incumbent on them as a duty.

« Those who condole at the time of the burial, says the said Classic (ch. 12, leaf 9), certainly grasp the drawing-ropes. And when they have followed the coffin to the grave, they all take hold of the veeringropes (172).

Commenting upon this passage, Khung Ying-tah, one of the most renowned interpreters of the ancient books in the $7^{\text {th }}$ century, says :

« Condoling at a burial in point of fact consisted in lending a helping hand in the management of the matters connected with it ; therefore the condolers did not fail to assist in pulling forth the funeral car. As for the men, employed at the ropes, their number was adequate to the social rank and position, and when the number was complete, the rest arrayed themselves behind the corpse. But at the grave, when the coffin was set down and lowered into the pit, they all, in unlimited numbers, took hold of the ropes.

Apart from the above extracts, we have in each of the Three Rituals evidence that the dead were formerly carried to the tomb by their fellowvillagers or clansmen. This is the same as to say, by the members of their family in the broadest sense of the word, for in China, even down to the present day, every clan and village is but the extension of a single family. In its description of the burial of an ordinary officer, the $I$ li says :

«When the pit has been ${ }_{\text {p.191 }}$ filled up with earth for one third, the principal mourner bows to the villagers (173),

thus expressing, as Ching Khang-ch'ing says, his gratitude for their activity and exertions. The Li ki has (ch. 55, I. 32) :

« Condoling does not simply consist in following the principal mourners (to the grave), but those of forty years (and under) must hold the ropes when the coffin is let down into the pit. And as to the villagers : those who are fifty (and upwards) go home with the mourners to wail, while those of forty (and under) wait till the grave is filled up (174). 


\section{The religious system of China}

vol. I

Finally, the Cheu li says :

«The clan chieftains order their people to protect and receive one another... in order that they may bury each other (175).

Even now the same custom prevails in most villages of Fuhkien province, which as a rule are inhabited by people of one clan name only. They carry each other's dead to the tomb gratuitously, though the family, if they can afford the expense, are required by custom to reward the men afterwards with small presents of money or articles of food. We do not doubt but the same practice obtains in most parts of the realm. Indeed, this best accords with the clannish spirit which, owing to the fact that the autonomy of the family and the village has ever lain at the root of the social organization of the empire, reigns supreme in the nation. Even many a citizen of a town is, in Fuhkien, carried to his last resting place by the inhabitants of the village in which he was born and his ancestors have lived, if the distance does not prevent the men from coming over for the purpose, especially if the deceased has acquired wealth and a high position, and has made a liberal use of his money and influence for the benefit of his birth place and its inhabitants.

Apart from such exceptional cases, the coffin-bearers in towns and cities are generally common coolies, hired by the undertaker. This is attributable to the circumstance that clanship is by no means strongly developed there, such big settlements consisting of an agglomeration of families with various p.192 surnames and no mutual coherence. In Amoy, such hired coffin-bearers are scarcely ever dressed in a uniform or anything approaching it. They generally march in the procession in the dirty clothes peculiar to the lowest classes of Chinese society, barefooted and, in hot weather, even half naked. They belong to the same class of men who are accustomed to proffer their services for carrying empty coffins from the coffin-maker's shops to mortuary houses (comp. p. 89).

In Amoy, there exist among the lower classes many associations, instituted for the purpose of assisting their members in the expenses of the funeral rites of their parents. Such pē-bú hōe or 'father-and-mother associations' mostly consist of a dozen or more members, who work under the auspices and the protection of a divinity of their own choice, in the face of 


\section{The religious system of China}

vol. I

whom the neophites are sworn on an auspicious day. Whenever a death occurs which falls within the sphere of their office, the brethern contribute money for the funeral, or take a sum from the fund, if one has been accumulated for cases of emergency ; moreover, in many cases they carry the coffin to the grave, dressed for the occasion in white mourning garments. Should the fraternity be composed of men whose social position, as being a shade higher, does not permit them to do the carrying themselves, they support the coffin on either side with their hands when the coolies shoulder it, to show at least their willingness to carry it to its last abode.

In Fuhkien we have seen hundreds of burials, but never in a single case did the bearers of the coffin wail or pour forth mourning dirges. We feel therefore compelled to conclude that the ancient custom of doing so, has in that province fallen entirely into disuse. At burials of the very rich there are nearly always an extra number of men marching around the catafalque, to support it with their hands when narrow spots have to be passed, or short turns to be made round difficult corners. These men also support it when the bearers wish to halt for a few moments to take breath, as then each bearer places underneath the carrying-poles, instead of his own shoulders, a staff with a small cross-piece affixed at the top, which he carries in his hand for the purpose. Let us p.193 note by the way that a coffin is invariably carried feet foreward, as is also the rule in Europe ${ }^{1}$.

If in bygone ages the family members and clansmen, who drew the coffin gravewards, howled and chanted so loudly that gags had to be used to muffle their voices, it is not surprising to see that still now-a-days the nearest kinsmen of the dead, while following the corpse to the grave, howl and lament bitterly. The wailing sons of the dead man follow immediately behind the coffin, in the deepest sackcloth mourning and with straw sandals on their feet. Their pigtails are unbraided, so that the long dishevelled hair flows down their back from under a mourning cap of sackcloth. Each one of them carries

1 Nature, which headlong into Life did throng us, With our feet forward to our Grave doth bring us : What is less ours than this our borrow'd Breath ?

We stumble into Life, we go to Death".

Musarum Deliciae, ap. Brand, Observations on Popular Antiquities, p. 463. 


\section{The religious system of China}

vol. I

the small mourning staff already mentioned on page 146 . Sometimes one or more of the sons walk at the side of the coffin, having one hand on the catafalque as it to help in conveying it gravewards, or as if to prevent it from carrying away their beloved father or mother. It is by no means unusual to see a man walking on either side of the eldest son to support him, the principal mourner being supposed to be so deeply bowed down by grief as to be unable to walk alone.

Should ceremonies instituted to gain the soul admission to the Western Paradise (p. 121 sqq.) have been celebrated before the burial, and a hoan provided by the family as a seat for the soul (page 125), this streamer is carried in the funeral procession by the eldest son of the principal wife of the dead man, to the exclusion of the elder sons by concubines or by adoption. Only in the event of there being no sons by the principal wife, have the other sons a right to carry it and thus to support the soul on its way to and from the grave. When the burial happens to take place while the great requiem mass, often alluded to, is being celebrated, the streamer also appears in the train, for, during these rites likewise it is made to play an important part.

Those of the sons who cannot attend the burial because they live abroad or are prevented by severe illness from leaving their homes, are represented in the funeral cortege by a complete suit of sackcloth garments together with a mourning staff, carried either on a tray or in an open basket by a servant or a remote kinsman p.194 in white mourning apparel. Besides implying that the child, who is unable to perform in his own person the sacred duty of burying his father or mother, is present in mind, the custom serves to show the number of sons the deceased has left behind, male offspring being in China not only a reason for happiness, but also for display and pride. Should the eldest or only male descendant of the deceased be an infant, it is, in sackcloth dress, taken to the tomb in the arms of its mother or nurse seated in a sedan-chair. Other male babies are usually represented by a suit of mourning clothes each, but infant sons, who are able to walk, are always taken to the tomb, carried, if necessary, on the back or the shoulder of fullgrown relatives. They are attired in sackcloth garments quite similar to those of their elder brothers. Some mothers think it prudent to tie a copper coin between their eyebrows by means of a red silken string fastened behind the 


\section{The religious system of China}

vol. I

head, to protect, as they think, their tender age from the attacks of nefarious influences.

Like every important rite in respect of the disposal of the dead, the journey to the grave is connected with loud lamentations on the part of the nearest kindred. Their melancholy concert may often be heard at a great distance. But, like all Chinese death howling, this too is chiefly a ceremonious wailing, a rite prescribed by the laws of custom and having little concern with real feelings of affection and grief (see page 11 ) in fact, tears are very rarely shed, and the howling is done with the same ardour and passion even if the dead man have departed this life years ago and can scarcely be remembered by the offspring. It is quite natural therefore that the wailing should cease in the open field, where there are no passers-by, and that it should immediately be resumed when the procession arrives at inhabited quarters, meets with remarkable persons or approaches dwellings of note. While watching burials, it has often struck us to see the mourners suddenly stop their cries to cast smiling looks of curiosity upon the foreigner so rarely seen, and then set up their howl again as soon as they had passed by the rara avis. The practice certainly deserves the name of an Irish weeping, and may be placed in the same category as the conclamatio of the ancient Romans, or the crying of the women, which Virgil, in his description of the obsequies of the Queen of Carthage, denominates by the term ululatus. But the Chinese of the present age do not, like the Irish, place a band of people in front of the procession, to set up, from the house to the burial p.195 ground, a most barbarous Holooloo-loo ; neither do we find with them the mulieres prœficæ of the Romans, who probably fulfilled the same office; neither do they, like the Javanese and many barbarous and semi-civilized peoples, follow the corpse to the grave with outcries so hideous and vociferations so frantic as to make the foreign spectator think himself in presence of a procession of raving madmen.

Besides the sons, all the grandsons and great-grandsons in the male line of descent walk behind the coffin, also, in the order of proximity, the brothers, male cousins and other relations by blood. Every one of them wears the deepest mourning attire prescribed for his specific degree of kinship to the dead. Finally come such distant relatives as take an interest in the deceased and his family, as also the friends and acquaintances, many of 


\section{The religious system of China}

vol. I

whom, not falling within the terms to wear mourning, are dressed in their best attire, or in the ceremonial robes thò p'ao described on page 49 sqq. Scarcely ever is a dead man followed to his last resting place by any one occupying a higher rank in the hierarchy of the family, because the rigid rules of social life, which demand that every one should adhere firmly to his position of superiority or inferiority in the domestic circle, cannot be changed by death itself in a country where the line of demarcation between the living and the dead is so faint. A father does not follow his child to the grave! This rule, however, does not hold good for the dead who belong to the same generation and are of inferior rank only on account of their sex or age ; e. $g$. a brother may appear in the funeral of his sister, an elder brother in that of his younger brother, a husband in that of his wife. But a husband does not follow his consort to the grave. He never followed her, she always followed him, and so it must ever be, even after death. Accordingly he walks in front of her coffin, wearing a specific mourning costume prescribed for widowers, and carrying a long staff about which more will be said in ch. VI of the third part of this Book, which is specially devoted to mourning and mourning dress.

The female members of the family, even the next of kin, such as the wife, the unmarried daughters and the daughters-in-law, only follow the coffin at the outset. Having gone a few dozen paces, they return home, without interrupting their wailing, always taking another street, as if ashamed that people who have seen the procession start, should perceive that they have

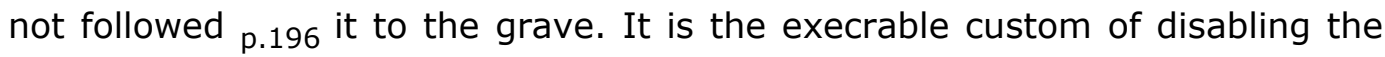
women by crimping their feet which compels them to abandon the procession so soon. The holy ancients acted otherwise, so that the present generation is blameworthy from an orthodox point of view, which accounts for the women's choosing another way in going home. Both the I li and the Li ki prove, that in the ages of the Cheu dynasty the female mourners went to the grave. Describing the interment of ordinary officers, the first-named work says :

« The women stand with their faces towards the east, and, while everybody abstains from wailing, the coffin is lowered. Parcels of black and scarlet silk in pieces of eighteen feet long are now presented to the dead.... and, this rite accomplished, the principal mourner bares 


\section{The religious system of China \\ vol. I}

the upper part of his body and makes reverences to the guests, the principal female mourner imitating him in this (176).

The $L i k i$ also says (ch. 13, I. 8) :

« On the death of the mother of Kwoh-chao-tszĕ, he asked Tszĕchang, saying: "On burying her, what should be the places at the grave for the men and women ? Tszě-chang answered : "At the burial of King-tszĕ, the Minister of the Multitudes, when Confucius directed the rites, the males stood with their faces to the west (i. e. on the east side of the pit), and the women stood with theirs to the east". "Ah, replied the other, that will not do.... Let the women stand behind the men and all have their faces towards the west (1777).

Still in the great codex of the state religion enacted in the $20^{\text {th }}$ year of the Khai-yuen period (A. D. 732) ${ }^{1}$ we find it formally stated amongst the rescripts regulating the burial of official persons, how the males and females have to station themselves at the tomb during the interment (178).

The ancient rule probably still obtains in many parts of the ${ }_{p .197}$ empire. In southern Fuhkien it is, at the present day, only followed in the event of the dead man having no male issue, so that all the duties of the sons devolve on his wife or unmarried daughters. These women are then carried behind the coffin in sedan chairs, if their crimped feet prevent them from walking, and they continuously wail and lament, as the sons would do in like case. Whether they accompany the dead for only a few paces or all the way to the tomb, the females are dressed in the deepest mourning prescribed for their respective degrees of relationship.

To accompany a dead man to the tomb is called sàng tsòng, 'to see off a burial'. The persons who perform this sacred duty, and those who follow behind them to show affection and esteem to the deceased and the bereaved family, generally form the rear of the procession. Hence we might herewith close our description of the funeral corteges if there did not remain a few things to be mentioned which appear in the same only exceptionally.

\footnotetext{
1 See page 236 .
} 


\section{The religious system of China \\ vol. I}

In the first place, in many parts of the empire one may see, a little in front of the pavilion with the soul tablet, a set of sacrificial meats, dainties and instruments of worship. These are carried either in one or more pavilions, or on large, square wooden trays, each suspended from a pole which rests on the shoulders of two men. The eatables are destined to be offered to the soul at the grave. They have formed a part of those which were placed on the tables at the great farewell sacrifice. Moreover, an assortment of fresh offerings destined for the God of Earth are carried gravewards in a similar manner.

We have said that such sacrificial articles only exceptionally appear in the procession. In fact, excepting the burials of high officials, when an entire goat and pig may be seen amongst the offerings, the latter are nearly always carried to the tomb by men who go their own way, regardless of the train, taking the shortest cut, to save time and labour.

Sending to the tomb part of the offerings which have done service at the farewell sacrifice, is again a usage borrowed from holy antiquity. After the description of the said sacrifice, reproduced on page 151 seq., the I li says :

«While the mourners stamp their feet as before, the persons charged with removing the offerings enter the gate. They remove the napkins placed over p.198 the offerings, and put the sacrificial meats into baskets, taking only the lower quarters of the victims, and not the fish, neither the dried meat (179). These baskets, which are of Phragmites grass, are three feet long and made of stalks of fully the same length (180).

And in describing the interment, the book mentions these baskets as among the articles which were deposited in the tomb all around the coffin, to remain buried there as an offering to the dead (181).

We also read in the $L i k i$ (ch. 13, I. 5 and ch. 54, I. 7-9) :

« The Ruler of a state has seven parcels of offerings and seven carriages for dispatching them, a Great officer has five parcels and five such carriages (182). The number of the carriages is proportioned to the parcels of meat. They are covered in with coarse linen and 


\section{The religious system of China \\ vol. I}

ornamented on the four sides. The parcels are placed in the four corners of the burial pit. Rice is also loaded upon the carts, but Yiutszĕ (a disciple of Confucius) has said that this is not consistent with the ceremonial usages, as, at funerals, nothing except dried and pickled meat must be offered (183).

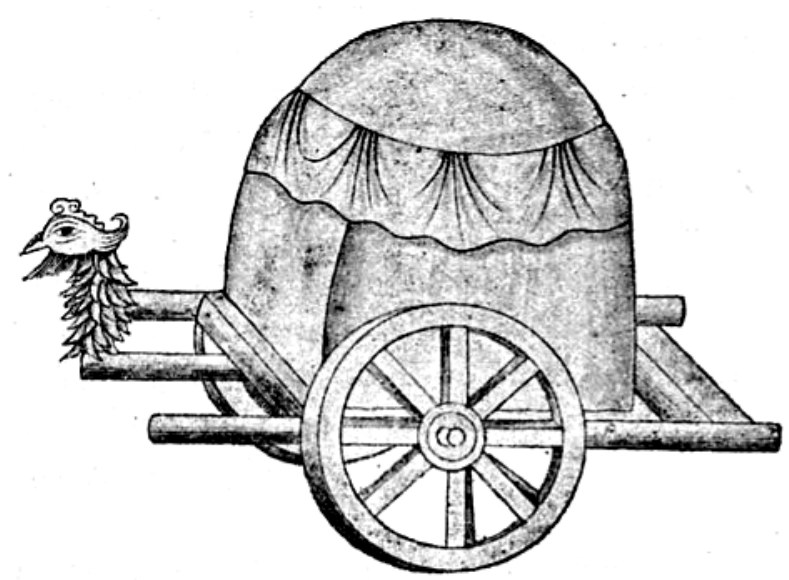

In Fig. 21 we give a picture of such a cart as found in Nieh Ch'ung-i's Illustrations for the Three Rituals. With some p.199 insignificant deviations in the details, the Khienlung editors have copied it from that work and inserted it in the $\mathrm{Li} \mathrm{Ki}$ and the $I / i$, respectively in ch. 82 and 44 .

Fig. 21. Cart for conveying Offerings to the Tomb.

As a second category of things seen only exceptionally at burials, must be mentioned large, square pieces of coloured silk or broadcloth, each fastened to a lath which is suspended from the top of a pole carried aloft, in the same manner as inscribed banners use to be carried amongst Europeans. They are decorated with eulogistic phrases implying respect and veneration for the dead, or referring to him and his future fate. Amongst the rich, such honorary banners are presented by friends and relatives to families who celebrate a great Buddhist mass for the repose of a deceased kinsman, that they may use them for decorating the walls of the hall. Hence they do not appear at a funeral unless that mass has already been celebrated, or is in course of celebration when the burial takes place.

In many parts of the empire it is customary to ornament such banners with boughs of green leaves affixed to the top of the pole. This custom exists also in West Borneo, amongst the numerous Chinese settlers who have emigrated from Kwangtung province. In that island, the present writer saw them carrying in the van long bamboos on which were left all the green leaves and twigs; they were thrown away about the grave when the procession prepared for returning home. This custom acquires a peculiar 


\section{The religious system of China \\ vol. I}

interest from the circumstance that a similar practice obtains in many parts of Europe, where yew, willow and cypress branches, ivy, rosemary, laurel and other evergreens are carried to the grave and cast into the pit when the coffin has been lowered, or laid over the grave after this has been filled up.

In the event of the coffin having been kept unburied for a considerable time, it is not unusual to see on the way to the grave a live white cock with its feet tied standing upon the catafalque. In many instances, this bird is kept in a state of drowsiness by spirits which are poured down its throat, lest it should endeavour to fly away or disturb the bearers by fluttering its wings. Though most Chinamen confess they do not know the meaning of this custom, saying it is merely a legacy handed down by a wise ancestry to its offsprings who without reasoning must act as they have done, yet it is not difficult to find a plausible explanation of it, if notice be taken of some ideas which are prevalent amongst the people about the cock and expressed in native books.

Since very ancient times the cock has been the acknowledged p.200 emblem of the sun, because every morning it loudly announces the rise of the God of the Day. The ancients even went so far as to identify it with the sun :

«It is, so an author of the $11^{\text {th }}$ century tells us, an old saying that in the sun there is a cock, and in the moon a hare (184).

But, whereas the sun is the chief embodiment of the great Yang element which, as the reader knows, represents the light, warmth and life of the universe, the cock naturally represents also an important depository of Yang matter :

«The cock, says the Ch'un-ts'iu shwoh thi tszĕ or Disquisitions on passages occurring in the Ch'un-ts'iu, is the emblem of the accumulated Yang (i. e. the sun) and of the South. Etherial things which partake of the character of fire and of the Yang element, have the property of flaming up; hence, when the Yang rises above the horizon the cock crows, because things of the same nature influence each other (185). 


\section{The religious system of China \\ vol. I}

Now, as we have said on page 22, the human vital energy also consists of Yang matter. Therefore it is not surprising to find that the Chinese have recourse to a cock, in order to strengthen a soul which is enfeebled to a great extent by having been so long compelled to wander about miserably in consequence of the delay of the burial, and which must make a wearisome journey to the grave. In this they act on exactly the same principle which teaches them to place a candle or lamp on the couch of persons who have just breathed their last (page 20), and to carry lighted lanterns and torches in funeral processions.

Besides, the use of the cock in funerals serves still another purpose : it keeps spirits of darkness away from the coffin. Indeed, such spirits being identified in Chinese philosophy with the principle of darkness Yin, everything which is imbued with much Yang matter naturally exercises a neutralizing, nay destructive influence over them. Moreover, it is an article in the creed of

all classes of Chinese society that the spirits of darkness, being unable to withstand daylight, are every morning put to flight by the p.201 crowing of the cock, standing as they do in perpetual awe of this bird. It would lead us too far from our present scope if we were to enter into particulars about the important position the cock holds in China as an exorcising agency. This subject will be amply dealt with in our Second Book, in the chapters specially devoted to Demonology. But we must not omit to note here that Chinese books furnish evidence that white cocks were anciently preferred to those of other colours for exorcising purposes, a fact which explains the reason why now-a-days such birds are used in funerals to the almost total exclusion of others. The great standard work on Natural History and Materia Medica, known as Pen-ts'ao kang muh or 'Collectanea of Plants' which was composed in the latter half of the $15^{\text {th }}$ century by Li Shi-chen and has since become a general vademecum for the whole host of apothecaries and quack-doctors in the empire, has in its $48^{\text {th }}$ chapter the following quotation from the Chen kao, a work written in the $5^{\text {th }}$ or $6^{\text {th }}$ century by one Thao Hung-king :

« If in the mountains you study the ways to attain higher perfection, then keep white fowls and white dogs, because they may serve to avert evil influences from you. 


\section{The religious system of China}

vol. I

« This is, adds Li Shi-chen, the origin of the practice in vogue amongst modern men of the black art, of using white cocks for exorcising purposes.

Some light is also thrown on the custom of placing a white cock on coffins by the following passage, occurring in the Pen-ts'ao shih $i$ or 'Omissions in the works on Botanics', a work written in the first half of the $8^{\text {th }}$ century by Ch'en Tsang-khi :

«If a white cock be fed during three years, it is fit to be employed by disembodied souls to serve them (186).

It is a matter of frequent occurrence that two members of one household are carried to the tomb in the same funeral procession. If, for instance, a husband and wife have manifested a desire to rest together in one grave, and one of the couple dies when the other is p.202 so old that death may soon be expected, the corpse is in many instances kept unburied for the time being, in order that both may be entombed simultaneously. Cases may also occur in which brothers and sisters die soon after each other and, their graves having been selected near the same place, the family prefer to bury them at the same time, to save expense. In all such instances the procession is arranged as if for one person only, but there are two soul banners, if they are used at all, and, of course, one set of soul tablets for each corpse. If both the deceased ranked on the same level in the family hierarchy, these tablets may be placed side by side in the same pavilion, should the family desire to limit the number of such vehicles for economy's sake; otherwise those of the person who died last are carried ahead of the others. For each coffin there is a special catafalque. It is the invariable rule at double burials to carry the person, who died last, ahead of the other. For, as the Chinese of Amoy express it, sin ts'oā $k \bar{u}$, 'the new corpse should show the way to the old one' ; indeed, reversing the order, 'the old dead opens the way to a new one', and this may have the fatal consequence that the last case of death entails another case, and so on, in endless succession. The necessity of precluding such a disaster has caused a precept of the holy Confucius to the effect that the principal dead ought to be carried foremost, to become a dead letter. This 


\section{The religious system of China}

vol. I

precept has been handed down to posterity by the $L i k i$, which relates (ch. 26, I. 12) :

«On being asked by Tseng-tszĕ : "What course is to be adopted when there is a double case of death ? Who is then first, who last ?" the sage answered: "At burials, the less important one should have the precedence, the more important one ought to follow (187).

Let us now make a rough estimate of the number of people composing a funeral procession of the highest order. In some that passed before us, we counted more than fifty pavilions including those contributed by friends and relations. Now calculating that each is carried by four men and escorted by two flag-bearers and a band of eight musicians, we obtain the considerable number of seven hundred. Add to these the mandarins' escorts, the persons p.203 in charge of the more important pavilions and of the coffin, the sixteen or thirty-two coffin bearers, the numerous mourners, friends and kinsmen in the rear, and so forth, the total number may without exaggeration be fixed at over one thousand persons. This cipher will still be considerably increased in wet weather, the undertaker having then an extra number of men in the train for the purpose of placing covers of oiled paper or linen over the catafalque and the roofs of the pavilions whenever a shower occurs, lest the costly material should be spoiled by the rain. Against this the highest cipher we may place as the opposite extreme that of burials of the very poor, who have to content themselves with what is strictly required, viz. one paper-scatterer, one shabby pavilion for the soul tablet escorted by one or two clarionet players only, and four coffin bearers, with a few mourners in the rear.

It would be a mistake to imagine that a Chinese funeral presents an edifying spectacle bearing the character of a civilized people under mournful circumstances. By far the most inspire a foreigner from the West with a feeling of disgust. In order to make as much money as possible, the undertakers employ as bearers of the coffin and the sundry pavilions the very scum of the streets, abject individuals addicted to opium, the upper parts of whose bodies are naked in summer, and in winter covered with only a few dirty garments. As to the banners, lanterns etc., they as a rule are intrusted to the care of impertinent, dirty paltry boys, who are to be had cheaper than 


\section{The religious system of China}

vol. I

full-grown men. Even those amongst the hirelings who wear something like a uniform do not make a more favourable impression, their clothing bearing traces of very long usage and a total absence of any idea of cleanliness. Lí sī tsit $\underline{\hat{e}}$ kng hng-hûn-tîng $\underline{\underline{e}}$ : 'You are the bearer of a soul pavilion', and Lí sì tsit ê kiáh ts'ái-kî $\underline{\hat{e}}$ : 'You are the bearer of a decorative flag', are in Amoy favourite expressions in the mouth of people when calling each other hard and ugly names, and also daily on the tongue of mothers when scolding their children for abject individuals of the worst kind.

As soon as the procession starts, these wretched, shabby creatures deem it prudent to yell and cry in a most unedifying manner. The bearers behind every pavilion give directions to those in front p.204 by loud screams and revilings, and are answered in like manner. A number of men run up and down the procession to maintain and to prevent the one part from going too fast and the other too slow, and they are continuously yelling and shouting at the top of their voices. The lictors, at short intervals, send forth their loud Iû. o. o. o., accompanied by the deep tones of the heavy gongs. But all the hubbub produced in this way is as nothing compared with the shrill tones of the detestable clarionets, of which there are so many in the train that the noise of the still more numerous drums and cymbals, mingled with the long plaintive sounds of the copper sackbuts, is drowned by them. After all, seeing that each band plays as it thinks best, regardless of those marching in the immediate neighbourhood, and seeing, moreover, that streets in southern China are for the most part mere narrow lanes crowded with busy passers-by, through which the procession can scarcely make its way without endless altercations: the reader will easily understand that a Chinese funeral is anything but a decent mourning ceremony intended as the last honour to the dead. From the variegated pavilions, flags and lanterns, and from the numerous bands of musicians, a foreigner not accustomed to such scenes might easily imagine he saw before him a cavalcade of semi-barbarians going to a feast.

Chiefly owing to the narrowness of the streets and the numerous impediments from the peddlers, coolies and shopkeepers, with which the train is every minute coming in contact, the order is continually being disturbed, in spite of the most strenuous efforts of the men appointed to maintain it. Even 


\section{The religious system of China}

vol. I

the undertaker, who has generally to provide for several burials on one day, will cause large gaps by hurrying on the van, in the hopes of compelling the rest to make haste. Often, on entering a city, we have seen the van of a funeral train calmly waiting outside the walls, and have met the rest of the procession in the streets a long while after. At nearly all funerals the undertaker is present in person to superintendent the arrangements, and this reminds us of the designator of ancient Rome, who used to walk at the head of the cortege followed by a certain number of lictors.

It is a fixed rule for burial processions to move forward to quick time. This may have something to do with a rescript in the $L i k i$ (ch. 10, I. 59) to this effect.

«It is desirable that in affairs of mourning there should be urgency, and that festive affairs should be gone about in a leisurely way. But, although affairs of p.205 mourning require urgency, one must not violate the prescribed rules.

It is prescribed by custom that, on the way to the tomb, at three or more spots properly agreed upon beforehand, the chief mourners should turn round and silently kneel down with their heads bowed to the pavement. They mean hereby to express their gratitude to the friends and kinsmen in the rear for honouring the dead and the family by their presence, and to intimate that they dare not expect them to go so far as the tomb. Some of the company harangued in this silent way are then expected to rush forward and help the mourners to their feet again, while a person, previously appointed for this duty, exclaims : Liet ūi siùng-kang, haò-lâm siā pō, 'File of noble gentlemen, the filial sons thank you for your presence here'. Such of the noble gentlemen as are not closely related to the deceased now leave the train and go their own way, the majority of them in sedan-chairs, which the family have politely stationed at the three points, to be made use of gratuitously by the departing guests.

This ceremonious sending away of those who have honoured the deceased by their presence is called sî kheh, 'to dismiss the guests'. At each of the three spots where it is done, a man in a white mourning dress is seated at a table, to take down the names of those who leave the procession, as custom 


\section{The religious system of China \\ vol. I}

requires the family afterwards to send presents in recognition of the marks of interest shown on such an occasion. At very pompous funerals, the recorder of the names is assisted by a few others, to provide against the chance of his meeting with faces which he does not know. The names of the donors of 'auxiliary pavilions' are also noted for the same reason. By the way it may be observed that, at burials of the highest order, it is customary to station men along the road to distribute siri-leaves and betel-nuts amongst the notable persons walking in the procession. Though most of them do not partake of these drugs, the use of the same being, as we have said on page 153, far from general, it would be inconsistent with good manners to refuse to accept them. So must men just hold them between their fingers, or give them away to the coolies or anybody who likes them.

p.206 So far for the procession. Now we have to watch the behaviour of the people on seeing it go past.

Established custom requires everybody to make room for a cortege of death, whenever and wherever it is met. Even the highest mandarin, moving through the street with a numerous attendance of lictors, soldiers and servants, forms no exception to this rule : - if the street is too narrow to allow two corteges to pass each other without collisions, he must patiently wait until the coffin has passed. In fact, by stopping a funeral, one might cause the auspicious hour, selected with so much care for letting down the coffin into the grave, to be missed, and so bring great misfortune over the dead man and his offspring ; besides, it is a holy rescript of antiquity lodged in the venerable $\mathrm{Li}$ ki (ch. 55, I. 14) that

«men of higher order should not deprive others of their funeral rites (188).

Many persons avoid funerals from superstition, believing they may bring life-destroying influences over them. Women call in their children who are playing in the street, and close the door behind them, or, if they cannot get away in time, they tell them to clasp their hands together and make slight reverences to the corpse and the soul, while they do the same themselves. That the doors of temples are closed, or the gods residing therein prevented in some other manner from seeing the cortege of death, has been stated 


\section{The religious system of China}

vol. I

already on page 155. If a procession carrying a bride to the house of her parents-in-law be met, this is considered to bring good luck to both parties. The accident will bring happiness to the bride and to the generation of descendants to which she gives birth, because the road, which she is going to take, has been purged by the numerous spirit-dispelling expedients that form part of the funeral : - no nefarious influences will now settle on her and work evil on the future happiness of herself and her offspring. On the other hand, the bridal procession undoubtedly emanates its influences over the corpse, and these, sown in the grave, must surely cause many happy marriages to be celebrated among the mourners and their descendants.

In his Social Life of the Chinese (ch. VII), Mr. Doolittle makes mention of sacrifices sometimes performed at Fuhchow at the expense of personal friends or relatives in honour of a distinguished p.207 man, either a civilian or a mandarin, while the coffin is en route to the grave. Tables, he says, with bounteous articles of sacrifice are placed by the roadside, the procession halts at the spot, and the coffin having been put down, one of the principal persons who united in making the sacrifice approaches and kneels down before the coffin. Some of the articles are then handed to the man on his knees, who presents them towards the dead. He retires, and another person takes his place, kneeling, receiving and presenting some food. Such a sacrifice honours the memory and the virtues of the departed in a manner very gratifying to the family of which he was once a member. In the summer of 1850 an illustration of this custom occurred at Fuhchow, when the corpse of exCommissioner Lin, of Canton opium-destroying notoriety, who died while engaged in an expedition against the long-haired insurgents, was brought home for burial. A large number of tables were arranged along the sides of the street on the island in the river. As observed at that time, the exhibition of articles offered to the manes of the honoured dead was far more extensive than a sacrifice on the premises occupied by the family of the deceased.

In the southern part of Fuhkien such sacrifices are of extremely rare occurrence, at least if we are entitled to draw such inference from the fact that during our many years' residence there we did not come across one single instance of it. Trustworthy persons, however, relate instances which have taken place in that part of the empire, adding that the mourners never 


\section{The religious system of China \\ vol. I}

neglected to thank the sacrificers by throwing themselves at their feet. It is clear that such roadside-sacrifices are repetitions of the farewell-offering presented by the family itself at the departure of the funeral procession from the house of mourning.

\section{The Interment.}

In case the grave is situated on an eminence, the place where the ground begins to ascend upwards is selected as the last spot for 'dismissing the guests' (p. 205). At this final summons all the friends and acquaintances retire, because, as we have said on page 104, the presence of persons whose horoscopes do not agree with the hour of burial, may have a bad influence upon the fate of the deceased, as well as on that of the owner of the horoscope.

Lest these retiring friends should have to make the long journey back on empty stomachs, the family of the dead have taken care p.208 to station at this spot some members of a numerous class of people who make it their special vocation to move about the streets with a portable furnace, selling cooked food to passers-by workmen, etc. Macaroni and vermicelli soup, mixed with boiled shrimps and oysters, is the special fare on such occasions, the long threads of this food being considered very useful in counteracting the life-shortening influences which the contact with death may have exercised (comp. p. 68). For every bowl of soup delivered, the peddler receives a stamped, counter-check from a friend or relative of the family, who is stationed for the purpose on the spot with a large provision of such documents; when the burial is over, he then calls at the house of mourning and converts them into hard cash. Similar soup-stalls are in some instances also stationed on the other spots where guests leave the procession.

The bearers of the catafalque, setting down their cumbersome load, break it up entirely. They tie the big rafter lengthwise over the coffin by winding some ropes several times around both and, casting the pall loosely over it, they carry the coffin up-hill, disembarrassed of all superfluous weight. This practical measure is not taken when the grave is situated in the plains, and the path presents no difficulties to carrying the whole catafalque to the edge 


\section{The religious system of China}

vol. I

of the pit, All the empty pavilions presented by the friends are left behind with the hearse, as well as their bands of musicians.

Arriving at the grave, the procession finds the pit perfectly ready to receive the coffin. It has been dug by some of the so-called thó kong, or 'earth-workers', under supervision of the same professor of geomancy who was employed by the family for finding out the grave (p. 102). If the burial has been deferred over seven days, so that it has been necessary to select a fit hour for lowering the coffin (p. 103), it may happen that this hour has not yet come when the procession arrives, in which case they must wait patient on the spot. The coffin having been set down on the edge of the pit, everybody, the mourners not excluded, sit down on the grass or idly stroll about, gossiping and smoking. No lamentation, not a single sound of mourning is heard all the while, and the music too keeps perfectly silent.

In many instances, it is considered highly salutary, even p.209 necessary, to subject the pit to a certain preparative and purgative process. One of the grave-diggers, descending, places one or more copper coins, provided by the family for the purpose, in each of the four corners, saying in a loud voice : An tsîn, beh hō kiáng-sun tsin tsâi, 'I depose money here, in order to cause your sons and grandsons to acquire wealth'. All the by-standers respond to this by exclaiming in the affirmative hó ah. It is clear we have here to do with a continuation of the practices observed at the preparation of the coffin for receiving the body (p. 89 seq.) and that, therefore, the ceremony is intended to cause the grave to emit influences which may assist the offspring in earning money. The five kinds of cereals and a few iron nails are subsequently scattered about over the bottom of the grave, with accompanying sentences worded like those pronounced on sowing the same things in the coffin.

This an khòng or 'deposing things in the pit' can, however, only secure wealth, food and offspring to the family if all the contrary influences, which might prevent the grave from freely operating in the way desired, are exorcised away. For this purpose, a fire-pan in which smoulders some 'purification-incense' (see p. 33), is held inside the pit by one of the gravediggers and moved along its four sides. Much more effective, however, than 


\section{The religious system of China}

vol. I

this tsing khòng or 'purging the pit', is a ceremony which in exceptional cases is performed at burials of the rich by the professor of geomancy. Barefooted, with blackened face and dishevelled hair, this worthy man, otherwise extremely dignified in his habits, as it becomes every man of learning in China to be, stands, sword in hand, on the summit of a neighbouring knoll, where his observations have taught him the so-called t'ien-tik hng or 'region of the benefits of the heavens' is situated, in other words, where the centre of the beneficial influences of nature lies, which the art of geomancy purports to converge upon the resting places of the dead. Having stood there for a while, crying and wielding his sword like a raving madman, in order to induce the said influences to rise out of their latent state and begin their operation upon the grave immediately, the professor scatters about him a great number of sheets of mock money for the unseen spirits which, if not p.210 propitiated in this way, might cool their wrath by neutralizing the effects of his work. Then he suddenly rushes down-hill, yelling at the top of his voice and brandishing his sword, with the object of bringing about a general sauve qui peut among the spectres. Subsequently he casts himself into the pit, wallows for a moment at the bottom, scatters more paper about him, and finally climbs out, to allow the coffin-bearers to let the coffin down. All the while the musicians make as much noise as their drums, gongs, cymbals and sackbuts can possibly produce, thus co-operating with him in driving the evil agencies away; besides, a great quantity of crackers are fired, and shots out of blunderbusses of the kind which are employed in China for firing salutes for mandarins.

This odd proceeding of the geomancer goes by the term hoah soa ${ }^{n}$-lîng 'to halloo the influences of the mountains', or kún soan-lîng 'to stir those influences up, to make them boil'. It will easily be understood that this matter entails an extra expense for the benefit of the professor. Indeed, dispelling evil spirits is a business so extremely dangerous, that nobody can be reasonably expected to undertake it unless adequately indemnified for the risks he runs.

The coffin-bearers now place the rafter lengthwise over the pit and unknot the ropes by means of which the coffin is affixed underneath the rafter, slowly veering them away amidst the beating of gongs, cymbals and drums. In case 


\section{The religious system of China}

vol. I

the dead possessed an official rank entitling him to a salute of blunderbusses on entering or leaving an official mansion, the same number of shots are fired when his body is lowered into the grave. The musicians play their instruments with all the power that is in their hands and lungs, the lictors shout out their Iû o. o. o., and the mourners loudly wail in obedience to the I li, which says in its description of the funeral rites for official persons :

« They now lower the coffin into the grave, the principal mourners wailing and stamping their feet an unlimited number of times (189).

Most of the bystanders recoil a few paces, lest their shadows should fall into the grave and harm thus be done to their persons. In this they act on the same principle as those who attended the coffining, these persons, as we have seen on page 94, preventing their shadows from being shut up in the receptacle of the dead. The grave-diggers and coffin-bearers, p.211 however, do not take this precaution. They deem themselves sufficiently beyond the reach of evil consequences by having wound the long strip of cloth, which, in southern Fuhkien, people of the lower classes are in the habit of wearing around their heads, tightly round their waists, so that their shadows cannot be separated from their bodies. The geomancer and his assistants are wise enough to stand on the side of the grave which is turned away from the sun. Many men pick a blade of grass and put it in their mouths, this likewise serving, as they think, to protect them from any evil connected with the interment.

As soon as the coffin has reached the bottom of the grave, the professor approaches, to ascertain by means of a compass and with a thread which he stretches lengthwise over the pit, whether the corpse lies exactly in the line which his calculations have taught him will best ensure repose to the dead and prosperity to the family. By means of the ropes, hoes and handspikes the coffin-bearers and grave-diggers adjust the coffin according to his orders, and finally lift it up a little with their hoes, to enable the other men to draw away the ropes. In many cases much time and labour are wasted ere this lóh khòng or tsin khòng, 'lowering or entering (the coffin) into the pit', is finished to the perfect satisfaction of the professor. For, according to the geomantic 


\section{The religious system of China \\ vol. I}

doctrines, the luck of the family may be spoiled for ever if the corpse deviates one single inch from the calculated direction.

The sons now throw their mourning staves away and, while one of the attending kinsmen picks them up to stick them side by side in the ground at the head of the pit, they proceed towards the pavilion which contains the soul tablets. Then, all the musicians playing their instruments and the lictors shouting out an awe-inspiring Iû $O$. o., the eldest son takes the hûn péh out, the second son the permanent tablet, and the third the incense-burner of the ancestors, and these three objects they place at the foot of the pit, the censer coming in front of the tablets. The permanent tablet is now deposed upon the lid of the coffin by the headman of the grave-diggers, and the sons, with or without incense-sticks between their fingers, kneel down, exclaiming : Laō pē (laō-bú) ah, khí lâi, 'Father (or mother), rise!' These words have the effect of p. 212 inducing the soul to enter the tablet. From this very moment the tablet is considered to be imbued with afflatus of the dead, and to have become his perpetual duplicate, to serve as a patron divinity in the domestic circle and there to receive the offspring's sacrifices and worship.

The grave-digger hereupon takes the tablet away from the coffin and hands it to the eldest son, who respectfully puts it back into its place at the foot of the grave. This calling upon the soul to take up its abode in the tablet is considered a ceremony of great import. Only those persons to whom the sacred laws of filial devotion especially assign the regular worship of the soul, viz. the sons, may make the summons. Hence, if the only male child be a baby, the person in charge of it at the tomb gives himself much trouble to make it stammer out the words, and only in case it cannot speak at all does he pronounce them in its stead.

In must parts of southern Fuhkien it is an established custom for the sons to take a handful of earth in the lap of their sackcloth garment and drop it on the coffin. They perform this ceremony in regular order of seniority. In Amoy it is known as p'è thô, 'to take earth in the corner of the garment'. No doubt it is expressive of the idea that, as burying one's parents is a holy duty, a child ought really to take an active part in it. That it is very usual for those who 


\section{The religious system of China \\ vol. I}

attend an interment in Europe to throw earth upon the coffin, we need scarcely say.

The soul streamer, which served to convey the soul gravewards, is now taken down from its staff and folded lengthwise over the lid of the coffin. But the family does not venture to place the name of the grandee, the supposed writer of the inscription, in the grave. If they did, they would undoubtedly bring the influences of death over the man and endanger his life. Therefore they remove the name by tearing off from the streamer a small piece of silk loosely pasted on it, on which, with a view to this, the name has originally been painted. The proceeding in question shows that the Chinese have a tendency to identify names with the persons who bear them, a tendency which may be classed on a level with their inability, already illustrated by numerous instances, of clearly discriminating between semblances or symbols and the realities which these call to mind. The surname of the writer of the streamer is p.213 not torn off, for being borne by tens of thousands of people, it does not represent a special person.

The provisory soul tablet, which likewise served the purpose of carrying the afflatus of the dead to the tomb, is also placed in the pit. The gravedigger, however, pulls off the pedestal and throws it away outside the pit as useless. At burials of the poor, who have to economize as much as possible, the man in some cases removes the silk also, that the family may take it home and use it for some other purpose ; but the part of the silk, which bears the names etc, of the dead, is left in the grave, as being the seat proper of the soul.

The slate stones engraved with the biography of the deceased, as also the censer and the candle-sticks that were carried along with them in the pavilion destined for those stones, are placed at the foot of the coffin, in a small vault made expressly for their occupancy. In the event of the corpse having been coffined on a day of 'reduplication of death' (page 99), the box with the cockroach, bedbug or louse is also put into the pit. Then come the ashes of the 'treasury money', neatly wrapped up in paper sheets (page 80); subsequently the coffin is covered all over with oiled paper over which comes a layer of straw, and finally the pit is filled up with a watery mixture of earth 


\section{The religious system of China}

vol. I

and lime. In time this mixture becomes very hard and forms a vault, which prevents the coffin from being crushed under the weight of the earth when it loses its solidity from the decay of the wood.

If during the earthing up of the grave rain happens to fall, the family feel greatly gratified. Indeed, China being so often visited by crop-destroying droughts, rains are ranked there among the greatest blessings which nature can bestow, for, without rains, there is no food, no raiment, no wealth. Consequently, abundance will reign in the family if the heavens pour down those blessings into the very place which is to become the source of their prosperity, the centre from whence their future luck is to emanate.

\section{Dotting the Tablet.}

Meanwhile, at a short distance from the grave, a mandarin who is actually in office, or one with a purchased title, has been patiently waiting with a complete retinue of lictors, soldiers and attendants. For his convenience a small house is hired there by the family for the day, or if there are no habitations in the neighbourhood, a tent or shed is put up for the occasion. This grandee has been p.214 prevailed upon to come to the grave, in order to perform a certain ceremony, the object of which is to fix the soul of the dead in the permanent soul tablet. To none but very notable families is the glory reserved of securing to this end the services of such a distinguished person.

As soon as the coffin is let down into the grave, the two graduates who acted in the train as attendants on the deceased's brevet of rank (p. 165), are dispatched with a complete band of musicians, to politely invite the mandarin to enter upon this duty. He quickly finishes his tea, many cups of which beverage he has, thanks to the care of the family, swallowed while waiting, and gets into his sedan-chair; his whole retinue follows, and so he is carried in procession to the grave, in the rear of the music. The graduates march ahead of him with an air of great importance. A majestic Iû $O$. o. o. resounds over the hills; shots from the blunderbusses and blows on the large gongs mark the moment at which he sallies forth. Approaching the burial site, he falls in with the mourners, who lie prostrate on the ground to receive him. If 


\section{The religious system of China \\ vol. I}

his rank be not too high to disallow of such condescension, he descends from his palanquin to decline such marks of respect from the mourners, urging them to rise to their feet, after which he continues on his way, under a renewed concert of Iû 0 . 0 . shouting and gong-beating.

At the grave, the mandarin is offered a seat ; this is placed behind a table, on the frontside of which hangs a cloth between the legs. His attendants arrange themselves on both sides and every one draws near, while the eldest son, followed by all the chief mourners, fetches the tablet from the border of the pit, or has it brought to him by one of the notable by-standers. Turning his back towards the sun, or to the east, which is the region specially devoted to light because every day this makes its appearance there above the horizon, he kneels down in front of the table. While all the musicians exert their lungs and hands to the utmost and the lictors cry Iû o. o., the son holds the tablet with both hands on his back, allowing one of the principal attendants to untie the writing brush and the vermilion ink which are fastened to the tablet. The ink is then moistened by a servant with some drops of spirits or, if a white cock has been carried along upon the catafalque, with some blood obtained by making a little incision in its comb; the pencil is dipped in it, and the mandarin rising, solemnly proceeds towards the kneeling mourner. At this p.215 moment the musicians and lictors become, if possible, more noisy than ever. All the by-standers with their parasols draw near, to assist the bearer of the large state-umbrella in screening the head of the mandarin from the sun's rays. This grandee now removes the string of coins and the red cloth from the tablet. Holding both these objects in his hands he receives the writing brush, breathes over it, slowly points with it to the sun and solemnly marks the frontside of the tablet with several dots. First he dots the topmost part, which in most cases is engraved or painted with the image of a sun in the midst of clouds, saying : Tiém thien, thien ch'ing, 'I mark the heavens, pour out all your purity, O heavens !' Then he marks the pedestal, pronouncing the words: Tiém tē, tē lîng, 'I mark the earth, operate efficaciously, O earth !' In this way the natural influences of the Universe are summoned to work upon the tablet and thus insure the happiness of the soul for all time to come. Now the frontside is dotted on the right and left at about the middle of its height, the words pronounced running : Tiém ní, ní ts'ong, 'I 


\section{The religious system of China}

vol. I

dot the ears, be acute, O ears !' ; then come two points at about the same height, but a little nearer the centre, with the words: Tiém bók, bok bîng, 'I dot the eyes, be sharp, $O$ eyes !' Then follows a dot on the character for 'males', which stands in a smaller column of characters at the side, indicating the male descendants who erect the tablet as an object of worship for the family, the accompanying words being : Tiém lâm, lâm tiōng siū, 'I mark the males ; males, live long !' - and in the end a dot is placed on the character [], 'tablet', the last one in the large central column. Not unfrequently this character has the shape [] and, receiving the dot on the top, is transformed into the required figure. The words pronounced here are: Tiém tsú, tsú hién lîng : 'I mark the word tablet ; display spirituality, O tablet !' This and all the foregoing formulas are uttered in so low a tone, that even the nearest bystanders can scarcely catch a word of it. In fact, fashion prescribes total abstinence from vociferousness in any man of position and rank, especially when he appears in public.

The object aimed at by the ceremony described is fully implied ${ }_{\text {p. } 216}$ in the last words of the dotter : 'May the tablet display spirituality'. Already imbued with the afflatus of the dead by the summons described on page 211 , it will, thanks to the power of the words pronounced over it, henceforth be surrounded with the vivifying energy emitted by heaven and earth ; it will hearken to the prayers and desires of the offspring ; it will have an open eye for their wants and for those circumstances of life in which they may be in need of the soul's protection and help; finally, it will cause the male descendants to enjoy long and happy lives, and so ensure to the soul itself sacrifices and worship for all generations to come. In short, the dotting is intended to infuse life into the tablet, or rather into the manes which inhabit it and are incorporated with it. A high mandarin is employed to perform the ceremony because it is believed that the influences, emitted by his person over the manes, will endow them with the power of causing the offspring likewise to become men of elevated position ; in other words, it is done on grounds similar to those which induce people to employ such grandees for nailing up the coffins and bearing the soul streamer in funeral processions. Families who cannot afford to employ a mandarin, have the tablet dotted without much formality by a literary graduate, by some person of learning, or 


\section{The religious system of China}

vol. I

by an old or a wealthy man. Should this person happen to be in mourning, having, as a relative of the dead, followed the procession, he is required by custom to put off his white or sackcloth dress before entering upon the dotting, as this rite is considered not to be of a mournful character. In many cases he first puts on the ceremonial thò p'aò attire (p. 49). At burials of the common people, the dotting is often performed by the geomancer, this man being reckoned to belong to the learned class, the highest cast existing. As a rule he does not demand an extra fee for this additional work.

It is not difficult to understand why, during the ceremony, the tablet is made to face the sun or the east, that is to say, the luminary or the region from whence all light, warmth and life of nature emanate. It is likewise easy to comprehend why the mandarin, besides pointing with the writing brush to the sun, breathes over it : breath is indeed considered by the Chinese to be one of the principal manifestations of animal life. The ink used for the dotting must be red, because red is the colour of fire and light and consequently particularly identified by Chinese philosophy with the Yang or the chief principle of life. And when the soul has been so much p.217 weakened by a long postponement of the burial that a cock is required in the procession to strengthen it, some blood of this bird is taken to moisten the ink, because it contains the vital energy of the very being which, as we saw on page 200, is a principal depository of the energy of the Yang and the sun, in short, of the life of nature. That the blood is taken out of its comb may, we believe, be safely ascribed to the puerile reasoning of the people that the fiery-coloured portion of the head or the most important part of the bird must naturally be the focus of its Yang energy. This suggestion is strengthened by the fact, that in the Chinese pharmacopæia blood taken out of a cock's comb holds a preeminent place amongst the means employed for pouring vital energy into bodies lingering between live and death, or even quite dead. Chapter 48 of the Pen-ts'ao kang muh says :

« How to treat persons expiring suddenly. If a sleeping person suddenly dies, this is always the consequence of his having been struck by a malicious agency. Take blood out of the comb of a cock, smear it on his face and, when it is dry, do so once more ; moreover, blow your breath into his nostrils and make a circle of ashes around 


\section{The religious system of China \\ vol. I}

the dead man. And if some one suddenly expire or lose speech, then take blood out of the comb of a cock, mix it with pills made of pearls and insert three or four of these pills in his eyes; this will produce a good effect. In the event of somebody having hung himself and thus being on the point of dying, you should, if he is still warm about his heart, not cut the rope, but prick the comb of a cock and drop the blood into his mouth, to set his mind and manes at rest. If somebody has hung himself and has not yet expired, then smear the blood of a fowl under his throat.

Finally, the work gives this receipt, p.218 borrowed, as it says, from the ancient 'Inquirer into Manners and Customs' Fung-suh thung $i$, a work of the second century :

«In case somebody has suddenly died by the agency of demons, then smear the blood of a black cock under his heart, and he will return to life.

Dotting a tablet at the grave is, in Amoy, denoted by the term tiém tsú, 'to mark the tablet'. The string of coins which was suspended on it and which the mandarin holds in his hand while going through the ceremony, has for its object to endow the tablet and manes with the property of rendering the offspring rich. The cock whose blood has been used is immediately seized upon by the bearers of the pavilion in which the tablet was placed on the way to the grave, as lawful booty allotted to their profession in virtue of an established custom.

The dead man has vacated the ancestral home, but his tablet will occupy the place left open by him; it will live on with the offspring as a patron divinity without whose help there can be no prosperity ; it will henceforth be the focus upon which the religion of the family is to concentrate itself. Considering the important part the tablet has to play in the future, it cannot be a matter of surprise that the ceremony by which the manes are fixed into it is looked upon by the people with the greatest interest and therefore associated in many cases with even more display than we have described. So, at pompous burials, it frequently occurs that two masters of ceremonies are appointed by the family to attend on the mandarin. One of these replaces him 


\section{The religious system of China}

vol. I

in pronouncing the formulas, and then, to increase their efficacy, he adds good-omened phrases. For instance, when the mandarin points to the sun with his brush, he says: Tsí jit, ko sing, 'He points at the sun, make promotion ( $\mathrm{O}$ offspring !) in the service of the State' ; when the last character is dotted, he exclaims : Tsú ka it tiém, tsú-sun ch'iong sing kho kah biên ting, "A point is placed on the character 'tablet', may the offspring become illustrious and prosperous, win the highest degrees at the State examinations and advance higher p.219 and higher in official service" ; and so forth. And when the grandee, having finished his task, throws the writing brush away, honour is rendered him by firing as many shots as his rank entitles him to.

At this moment the illustrious man approaches the grave, to the foot of which the eldest son or a kinsman has in the meantime brought back the tablet, his intention being to prostrate himself there in worship of the soul. But it is exceptional for the sons to permit him to execute his purpose. They throw themselves on their knees before him, thus humbly entreating him to retire, as neither the deceased nor themselves are worthy of such condescension on the part of a man of his standing; but the real motive for their protest is a fear the service may become too expensive for their purse, as custom requires that at least double the fee be paid to the mandarin if he also worships the soul. When the dignitary prepares to get into his palanquin amidst the sound of gongs and loud Iû o. o. cries, all the sons throw themselves on their knees, to express their gratitude for his valuable services. Now it is the great man's turn to decline these arts of reverence. Rushing up to the prostrated men, he urges them to stand up, at the same time extending both his arms as if to assist them in rising; then he disappears in his sedan-chair and goes off with a salute of shots. One of the attendants has meanwhile taken good care to place a large piece of red cloth over the roof of his vehicle, as was also done in the case of the mandarin or graduate who came to the house to nail up the coffin (p. 97). Occasionally a couple of gilt paper flowers are added to the cloth. Hurrying on a dozen paces in advance of the mandarin, the mourners once more prostrate themselves, to which courtesy the dignitary tries again to put a stop in the way abovedescribed, or, if he is too high in rank to descend from his palanquin, he merely pours forth a few polite phrases. 


\section{The religious system of China}

vol. I

Sacrifice to the Divinity of the Soil.

In the meantime some relatives and servants have been busily occupied arranging the sacrificial articles, spoken of on page 197, partly at the foot of the grave, partly on the right or left side where a small altar will have to be erected to the God of Earth (see p. 26 and 30), such as is to be seen at every tomb of note. As a rule both sacrifices are simply set out on the ground, but at very pompous burials that of the God of Earth is exposed on a table which has an embroidered cloth in front. Besides other p.220 articles of food, this sacrifice consists of the five sorts of meat mentioned on page 142, reduced by poor people to three. When the ceremonious dotting of the tablet is drawing to an end, the literary graduates repair again to the shed or the small house hired as a waiting room (see p. 213), to invite another mandarin, who has in the meantime arrived there with his retinue, to come to the grave and present the sacrifice to the god.

He is ushered up to the grave and saluted there with the same courteous observance as his colleague who dotted the tablet. Having taken up a position in front of the sacrifice, one of the graduates tenders three burning incensesticks to him, which he immediately presents to the god by holding them up with both his hands on a level with his eyebrows, bowing at the same time. Then a graduate on the other side places the odoriferous matter in the censer standing amongst the sacrificial articles, and the mandarin kneels down on a mat, bows his forehead three times to the ground, solemnly rises and retires. $\mathrm{He}$ is seen off with exactly the same ceremony as the dotter of the tablet, red cloth and gilt flowers being likewise placed on the roof of his palanquin.

While the grandee is thus paying honours to the god, the mourners humbly keep behind him in a kneeling attitude. All his movements are directed by one of the graduates, who in the Mandarin tongue instructs him loudly in a protracted tone of voice when to begin an act, and when to cease. On his right hand side a member of the family politely performs the rite of prostration simultaneously with him (pôe pài, comp. page 150).

We need scarcely say that the presence of a third mandarin carries the pomp of the burial up to the highest pitch. It is he who places the crown upon the great work of interment, a work which the descendants expect will secure 


\section{The religious system of China \\ vol. I}

them wealth, glory and prosperity for all future ages, a work indeed which shall insure them offices and dignities in the service of the Son of Heaven. To understand this aright, the reader must know that, in China, the emperor is the second being of the whole universe; nobody is above him but the God of Heaven, the highest deity of the Pantheon, of whom he is the only son and vice-regent on earth. As over all human beings, he also bears sway over all divinities ; and even these stand in rank and position below a mandarin in his quality of imperial proxy. Now it is easy to see, that employing a mandarin to present a sacrifice to a local divinity of the Soil must be very flattering to this god, nay, the highest honour which can possibly p.221 be conferred on him. Infinitely gratified by this testimony of respect shown him by the family, he cannot but feel himself in duty bound to reward them for it by always showing his extreme solicitude for the fate of the dead entrusted to his keeping. With a liberal hand he will pour out over the tomb the beneficial influences of the earth at his disposal, and all the blessings a good grave emits will, as a natural consequence, fall to the lot of the offspring.

From the above it naturally follows that, the higher the rank of the mandarin is, the more glorious are the results which the family may expect to derive from his intervention. In 1886, at a very pompous burial of a literary graduate of the second degree (Kü jen) and his wife, which the writer witnessed at Amoy, no less a personage than a Hai Fang Thing or Maritime Sub-Prefect, the highest local authority, performed the sacrifice to the God of Earth. On the same occasion the Tao Thai ${ }^{1}$ or Intendant of the Circuit comprising the departments Ts'üen-cheu-fu, Hing Hwa-fu and Yung Ch'uncheu, a mandarin of only one degree less than the highest, acted as dotter of the tablets, while the Ts'an Fu or Commander of the Brigade which has its head-quarters in Amoy, carried the soul banners. All this pomp was chiefly due to the circumstance that one of the sons of the deceased was a literary graduate of the first rank (Tsin shi), a man therefore who had carried off the highest honours at the State examinations.

As soon as the mandarin who has worshipped the God of Earth disappears from the scene, the sacrifice, so solemnly begun by him, is continued by the

1 This dignitary has been mentioned already on page 134 . 


\section{The religious system of China}

vol. I

mourners. Incense is presented by the eldest son, the 'threefold presentation of spirits' performed, a written offertory read off aloud by one of the graduates, and the ceremony is closed with the customary number of deep prostrations, everything just the same as at the sacrifice previous to the removal of the coffin out of the house (page 141). The principal junior mourners, and eventually those of lower degree, likewise bow their heads to the ground in regular succession of kinship, and in the end a bonfire is made of mock money, to enrich the god. The offertory too is cast into the flames, to reach the p.222 throne of the divinity through fire and smoke. This document is written on red paper, as a god would feel offended if he were addressed on the unpropitious colour of mourning.

In many cases, the mandarin, instead of going off so soon as we have described, also presides at the 'threefold presentation of spirits' and the prayer-reading in lieu of the eldest son. Anyhow, the prayer contains his name and title, as he is regarded as presenting the sacrifice even though he does not remain to the end. Here is the original text and a translation of such a prayer, which was actually used at one of the burials personally attended by the writer.

\section{$[\ldots]$}

In the $13^{\text {th }}$ year of the Kwang sü period, being the cyclus-year ting-hai, in the first month denoted by the cyclical characters jen-yin, and on the day jen-ch'en which is the p.223 third from the new moon, I, Thang Pao-kien, officer presiding at this sacrifice, Mandarin Expectant with a Prefect's brevet, have carefully provided an offering of sacrificial victims, spirits, sundry delicacies, incense and paper ; and, whereas a dwelling has been sought out by auguration on this spot for the chief of the family Ngeu-yang, an Intendant Expectant of a Circuit and deceased father of Ngeu-yang Kung-ch'u who is a Second Class Assistant-Secretary of the Board of Punishments, I venture to present the said articles as a sacrifice to Thee, O Ruler of the soil in these mountains and God of Happiness and Benefits, saying : 


\section{The religious system of China}

vol. I

Grand and immensurable are the felicities and blessings bestowed by Thee, O Glory of the water-streams and mountains. Thou reignest supreme over the element Earth, and respectfully call we Thee the Spiritual Energy of the Mountains. From Thy see Thou controllest the regions at the eight points of the compass, in rank Thou comest immediately after the emperors and sovereigns ${ }^{1}$. Thou maintainest the equilibrium between the four great terrestrial continents; Thy blessings overshadow the all-pervading influences of the winds and the waters. During thousands of autumns Thou hast overfilled the sacrificial dishes of mankind, and for ten thousand antiquities Thou hast enjoyed their sacrificial victims. The chief of the family Ngeuyang now settles in this City of excellence (grave), measured out and built in surroundings which compose the ne plus ultra of configurations, and we fully trust that his cavern of death may rely on Thy awe-inspiring, efficacious protection. In this sepulchre we deposit him, in order that it may cause his male offspring continuously to grow out like gourds and melons in lines unbroken ${ }^{2}$, and that it may cause a happy posterity to wear red fringes on their heads from generation to generation ${ }^{3}$. A pure sacrificial meal I have respectfully prepared for Thee as a testimony of my sincere devotion, and kneelingly I hope that Thou mayest look down upon it and descend to enjoy its savours. Mayest Thou enjoy it !

p.224 Offering to a local divinity of the Soil is denoted by the term sū Hō Thó, 'sacrificing to the Empress Earth'. In a great many cases this rite and the dotting of the table are both performed by one and the same mandarin, which saves expense. When circumstances prevent the family from employing more than one mandarin and yet forbid their entrusting both the rites to this one, for fear the presents to be paid for his services may exceed their means, they will always have the dotting done by him, this ceremony being considered of

1 Observe that the sovereigns of the empire stand above the gods even after their death.

2 In the wet and hot season of the year these plants grow in China with remarkable speed, sending forth numerous creepers over the ground in every direction.

3 Hats with red fringes like those described on page 50 form part of the uniform dress of mandarins. 


\section{The religious system of China}

vol. I

higher import in securing the future greatness of the offspring than the sacrifice. Hence it follows that, if two mandarins are employed, the dotting is intrusted to the highest in rank.

We have not come across any passages in the ancient books of rites from whence it might be inferred that the sacrifice now under notice existed already before the Christian era. But, summing up in its $12^{\text {th }}$ chapter (I. 35) a few practices anciently connected with burials, the $L i k i$ says that, when the principal mourners have left the grave to return home,

« an officer sets out sacrificial articles on low tables and mats to the left of the grave »(190).

Though Ching Khang-ch'ing, the Nestor of commentators, declares that this sacrifice was undoubtedly intended for the soul of the dead, yet Khung Yingtah, an authority of no less renown who lived more than four centuries after Ching (see p. 190), advocated the view that it was addressed to the spirit of the Soil ; and it is perhaps to be ascribed to his influence and that of his school that a sacrifice to this divinity was adopted by the Thang dynasty as an institution of the State and as such found a place in the great codex of official rites enacted in the $20^{\text {th }}$ year of the Khai yuen period (A. D. 732). This codex, on which we shall have more to say on page 236 , prescribes that it shall be presented by an official on mats spread out on the left side of the grave, and that it shall be connected with a short offertory answering to a given formulary. It is probably owing to this precept that the sacrifice, based on what seems to us a rather arbitrary interpretation of a hazy classical passage, has been maintained by subsequent generations as an integrate part of their funeral rites.

The Sacrifice to the Deceased.

p. 225 The priests who accompanied the procession have meanwhile been very busily engaged reciting soul-saving canons, formulas and litanies at the foot of the grave, with the accompaniment of handbells, wooden clappers and musical instruments. This meritorious work draws to an end when the mourners, after having finished the sacrifice to the God of Earth, are preparing to present the sacrifice to the soul, the articles required for which 


\section{The religious system of China}

vol. I

have also been brought to the tomb (see p. 197). We refrain from giving a description of the way in which this is offered, as it is quite similar to that followed in the case of the God of Earth, and only insert a specimen of the offertory recited, in order to convey to the reader an idea of the general tenor of such documents.

\section{$[\ldots]$}

In the $13^{\text {th }}$ year of the Kwang sü period, being the cyclus-year ting-hai, in the first or jen-yin month, and on the p.226 day jen-ch'en which is the third from the new moon, the unfilial orphan son Kungch'u and the other mourners carefully set out an offering of sacrificial victims, spirits, sundry delicacies, incense and paper, and present it to the manes of their deceased father, chief of the family Ngeu-yang, addressing them in the following terms :

Oh, what sorrow, what pain! During a long period of time, $\mathrm{O}$ father, Thy fame was on the lips of all in our native place, and we were just fervently hoping that an unlimited age would be granted to Thy eminent virtue, when unexpectedly Thou hast departed to the West, from whence there is no returning in the barge of mercy ${ }^{1}$. The calamity of death has befallen our deceased father ere we, immersed in heavy sins and profound wickedness, have requited the favours bestowed by him upon us during the course of our lives; so, sending up long protracted cries to the azure canopy of heaven, we provide for Thee a resting place here in this ground. The crane's chariot soars away through the sky ${ }^{2}$ : like gibbons we scream for sorrow and grief. We entreat Thee, establish Thyself in this grave; suffer Thy mortal coil to be installed in this burial cavern, and allow Thy soul to return with us to the hall of our home! At these our words our eyes fill with tears and our hearts feel alarmed; for indeed, there is alas nothing here but wind, trees, shrubs and twigs; this high land with

\footnotetext{
1 Kwan-yin or Awalôkitêçwara is said by the Buddhist Church in China to convey souls to Paradise in a ship.

2 Departed souls are sometimes popularly represented as repairing to the regions of bliss on the back of a crane.
} 


\section{The religious system of China}

vol. I

its water-springs is so vast, so sandy ; clouds and vapours soar over it. Thy solitary abode will be boundless and dreary ; therefore come home with us, $\mathrm{O}$ soul ! Abide here on this spot during the hoar-frosts of succeeding autumns and the dews of springs, as long as Earth shall exist and Heaven last ! Each handful of earth is to us a draught of sorrow, which rends our bowels asunder. O father, may Thy manes look down upon these pure sacrificial goblets! Alas, woe is us! 1 Mayest Thou enjoy this sacrifice !

The sacrifice is concluded with a bonfire of paper money, into which the prayer is also cast. The khai-lō sin which, up to this moment, has faithfully stood by the side of the grave on the watch against malign spirits, is made to return to its disembodied state p.227 by being committed to the flames. The principal mourner removes the tablet from its place behind the offerings, and reverently puts it back in the same pavilion in which it has been brought to the tomb; this done, he thanks the geomancer and the headman of the grave-diggers for their services, with courteous bows to each in particular. Another mourner meanwhile places the incense-burner in the pavilion of the tablet, while some of the relatives distribute small parcels of evil-dispelling red silk threads to everybody present, excepting the musicians, coolies, pavilion-bearers and such like rabble. The grave-diggers in the meantime have eagerly appropriated the offerings which were presented to the Divinity of the Soil. They divide them amongst themselves as their emolument, but the edibles that were offered to the soul they may not touch, custom requiring these to be consumed at the funeral meal which is to be given in the house of mourning. Hence the men, who have brought them to the tomb, pack them up again and take them home.

The Return of the Procession.

The cortege returns in the same order in which it proceeded to the grave. As the tablet now plays the principal part, the procession is spoken of as hoán tsú, 'the return home of the tablet'. The man who scattered about paper

\footnotetext{
1 As in the case of the recital of the prayer at the farewell sacrifice on the premises (page 149), the mourners at these words simultaneously burst into wailing.
} 


\section{The religious system of China \\ vol. I}

money in the vanguard now places himself amongst the relatives in the rear ranks, no such distribution to the evil spirits being deemed necessary on the way home. The empty bier is never allowed to get mixed up with the train. In fact, since the soul is taken home to be happy and prosperous in the midst of its offspring, whom it in turn is to render happy and prosperous by its blessings, the procession now bears a festive and cheerful character; hence there is no room in it for signs of mourning. For this reason the mourners entirely abstain from wailing and lamenting, until they come within sight of the house. All the bands, however, play assiduously in a cheerful key, as the Chinese say.

Care is always taken to go home by the same road which was followed to the grave, the soul having become to a certain extent familiar with this way and being therefore less exposed to the danger of going astray. To assist it in finding its way, the torches, which were extinguished on reaching the grave p.228 (p. 179), are relighted and carried in the van of the tablet. The lanterns bearing the inscription 'Hundreds of sons and thousands of grandsons', suspended from the palanquin of the soul (p. 172), now do excellent service by bringing influences, which may enable the soul to bless itself and its offspring with an endless line of descendants, from the tomb homewards, influences which, as the reader may remember, were carefully sown in the coffin and the grave by artificial means truly wonderful.

Before reaching the house, the procession comes across the female members of the family in sackcloth garments, who wailingly lie prostrate on the pavement of the street to receive the tablet. This act of respect and courtesy towards the departed is called tsih hoán tsú, 'to receive the returning tablet'. As soon as the procession, the females in the rear, halts on the premises, the principal mourner takes the tablet out of its vehicle, the next mourner the 'soul-body', if this has figured in the procession (see p. 173), and the third one the incense-burner, and these sacred objects they reverently carry through the main entrance, to arrange them on the table which stood in front of the coffin before the burial. The lictors and musicians give solemnity to this act by respectively crying and playing with their most strenuous efforts. And now, while the crowd of attendants with the musicians take their station in the lower part of the hall or in the court-yard in front, the 


\section{The religious system of China}

vol. I

priests recite a few formulas before the tablet to set the soul at rest, upon which the mourners, having changed their sackcloth garments for gowns and caps of white linen, commence a series of prostrations, in every instance preceded by the usual presentation of incense-sticks, being assisted herein by two masters of ceremonies. The more removed kinsmen generally confine themselves to prostrations only, carefully observing one another's social position, age and order of relationship as they succeed each other. If they are numerous and time is short, they prostrate themselves in couples or greater numbers at a time. When all the males have taken their turn, the women emerge from the inner apartments and go through similar sets of reverence.

\section{The Funeral Entertainment.}

During these prostrations the procession disperse, returning to the undertaker's shop, or going to a second house of mourning p.229 which has a funeral on the same day. The red name-cards affixed on the back-panels of the 'auxiliary pavilions' are first torn off by the family, to check the list of the donors prepared on the road (p. 205), after which they are returned to the owners of the pavilions, who present them at the houses of the donors when collecting their bills.

Subsequently the mourning garments are all taken off and everybody sits down to a sumptuous banquet. As at large festive meals in general, the guests are arranged around several tables, with strict observance of each one's social position, age, and rank in the family hierarchy. The principal seats are politely offered to the mandarins who took such an active part in the burial. He of the soul streamer has come hither with the procession; the two others have made their way to the house of mourning of their own accord. We need not say that the graduates obtain seats of honour. Servants are sent out in all directions to those who have seen the dead man to his grave but have not as yet made their appearance, in order to prevail upon them to join the feast. Among those invited are the geomancer and the headman of the grave-diggers; indeed, these men must be well treated, because the repose of the departed soul and the happiness of the family depends so much upon them. At many a notable burial, the number of guests is too great for them all to be seated in the hall and the adjacent apartments. 


\section{The religious system of China}

vol. I

Then the family are obliged to hire some apartments in their neighbours' houses for the feast.

In obedience to the established rules of decorum, the women do not join the society of the men, but they celebrate the feast of the dead amongst themselves in the inner apartments. Neither do the mourners mix with the guests. They take their meal in a separate room or in some inconspicuous part of the house, both law and custom forbidding their taking part in any festivities so long as they are in deep mourning. Doing the honours at this banquet consequently devolves on the other relations and the friends, one of whom presides at each table.

As to the food which is served up, it is especially noteworthy that the offerings used at the farewell sacrifice on the premises and at that to the manes at the grave form the chief part thereof. The food has in fact been brought home from the grave for this purpose, while that offered to the God of the Soil was given a way to the grave-diggers. From this it is sufficiently evident that the idea lying at the bottom of the burial banquet, is to let p.230 the dead and the living partake of one meal together. In many cases every table is served with at least one dish of the so-called âng tsao bah, 'meat of red sediment', being pork cooked in a red condiment which is prepared from the refuse of the distillation of spirits. This food is intended to promote the welfare of the eaters, because, being very red, it wards off unpropitious influences in general and those resulting from contact with death in particular. While the guests are decorously satiating their appetites, music and merry sounds are conspicuous by their absence, such things being considered inconsistent with mourning.

The repast over, every guest is seen off by the mourners, who pour forth all kinds of polite phrases to express their profound gratitude at his having honoured the dead and the family by his presence. With regard to the mandarins, they even go so far as to prostrate themselves on the floor; but this humble expression of their thankfulness is invariably declined in the customary way. When the official, who carried the soul-streamer, leaves, he receives a couple of gilt flowers and a piece of red cloth over his sedan-chair, as did his two colleagues on leaving the burial ground. Most of the guests are 


\section{The religious system of China}

vol. I

carried home in palanquins courteously provided at the expense of the mourners.

The ladies, who have spent the day in the home of mourning to assist in preparing the banquet and in doing other work, are likewise sent off in palanquins. On leaving, each of them is presented with a couple of red tapers, to be burned on their domestic altar ; further they receive some mock paper money which is to be reduced to ashes on that sacred spot, a pair of gilt paper flowers symbolizing the wish of the mourners that abundance may reign in their house, and about a dozen of the red cakes or âng $\hat{i}^{n}$ mentioned on page 76 . These cakes are intended to convey the same idea as the red meat condiment served up at the entertainment. In many instances sugar is added to these articles, as a sign of the wish that sweetness of life may fall to the lot of the person to whom it is given. Many families send these presents to the homes of the persons for whom they are intended, being of opinion that this is more in keeping with good manners. The male persons who have lent a helping hand during such a busy day, are favoured with like gifts. Finally it remains to be said that p.231 some of the guests, especially those belonging to the female sex, purify themselves at their own homes in the way described on page 32.

The funeral banquet is not always celebrated immediately after the interment. The burial may occupy the greater part of the day, so that sufficient time does not remain to properly entertain many guests, in which case only a luncheon is offered and the great meal postponed to the day following. In cases - not unfrequent - of the burial taking place during the night because of the day-professor not having been able to find a lucky hour falling within daylight, the same thing may occur. On some occasions, those are immediately regaled who have returned with the procession to the house of mourning, such guests as have left previously being invited the next day, or even the day following that. 


\section{The religious system of China \\ vol. I}

\section{CHAPTER VIII}

\section{Usages after the removal of the coffin and after the burial}

p.232 Among the rites performed after the removal of the coffin out of the house of mourning, the first which deserves notice is the so-called teh koan $\bar{u} i$, 'putting things in the place where the coffin stood'.

As soon as the deceased is carried out of the hall for burial, a female member or acquaintance of the family, who is reputed to be a happy creature because she is of a great age or well-to-do, or the mother of many sons, and so forth, stations herself, either in a standing attitude or sitting on a chair, upon the vacant place, in order to neutralize by the influence of her auspicious personage the inauspicious influences which stick to the spot in consequence of the long presence of death. This wonderful effect is still enhanced by her dress, in which no trace whatever of mourning is to be seen ; moreover, some gilt paper flowers are stuck in her hair to increase the luck promoted by her person. In some cases, a male member of the family or even a hired individual, who unites in his person the enviable and propitious qualities mentioned above, acts in lieu of the woman.

After this lucky person has been seated for a while on the spot, she retires and gives place to a number of things which the family set out on the same place to produce the same effect. We may mention a hoat ké or 'fermented tart' of flour, to cause the quantity of food in store in the house henceforth to swell and increase like fermented food ; further, a mixture of the five cereals, a few pecks of uncooked rice, some ten pairs of chopsticks and so many small bowls such as the Chinese use to eat out, all of which serve to prevent the spot in question from ever causing want of food in the house, or want of inmates to consume it. A bucket of water in which are a couple of silver dollars and a few copper coins, is also set down there, to ensure acquisition of riches produced by the fertilizing waters of heaven; further, a handful of charcoal, in order that fuel may ever be abundant in the house ; a hoop of 


\section{The religious system of China}

vol. I

bamboo, that felicity in the house may be round or, as we should say, complete and perfect ; lastly, a couple of artificial flowers which, being styled ch'un ki, 'vernal sprigs' p.233 or 'sprigs of profusion', are endowed with the property of causing the family always to have enough and to spare, as in a fruitful spring. About the hour the funeral procession is expected to return, just as many couples of red tapers are lighted on the spot as there are mourning sons; and when the latter re-enter the dwelling, each one takes his couple into his private room, to transplant thither the felicity created by the happy person and the felicitous articles.

The ceremonious cleansing of the house, described on page $107 \mathrm{sqq. \text {, }}$ is as a rule performed after the burial when this takes place only a very few days after the decease. We had already an opportunity to note this on page 111.

Now turning our attention to the day following the interment ; especially in summer, when meat and edibles in general are liable to taint speedily, this day is set apart for sending slices of the pig's-heads which figured amongst the offerings at the farewell sacrifice on the premises (page 143), to those who, shortly after the demise, came to the house of mourning to pay homage to the dead and to condole with the bereaved family. Some of the remains of the burial entertainment are added to each portion, e. $g$. part of fermented tarts, some of the fowls and ducks and so forth, the quantity and quality varying in proportion to the value of the coffin-paper presented at the visit of condolence (see p. 31). In this way, the persons who showed an interest in the family but did not attend the burial feast are enabled to partake of it, though in a different way. To those who did not come to condole in person, but simply sent coffin-paper to the mortuary house, presents of food are also made. It is customary for those who receive such a present to place in the basket, in which the articles are brought to their house, a few sweet-meats, expressive of their desire that the sweets of life may fall to the lot of the mourners; the rules of etiquette further bind them to pay the messenger for his errand with money wrapped in red paper.

When there has been a postponement of the burial for a considerable length of time, this distribution of edibles does not take place, the 


\section{The religious system of China}

vol. I

recognitions in the shape of presents having in such case been sent round already previous to the interment (see p. 110 seq.).

On the same day or, if there be no more time for this, on one of the following days, presents are also sent to all persons of distinction who took an active part in the burial. Among them the mandarin who dotted the tablet is the first and principal. A messenger is sent to him with a parcel of silver, the value of p.234 which depends upon his rank and upon the wealth of the family; and this messenger, on delivering the money at the gate of the Yamen, receives the mandarin's card, which be must take home as a proof that the present has safely reached its destination. In some instances, as when the grandee's rank is very high and the family are not on terms of intimacy with him, the male mourners, dressed in plain white clothes, repair in a body to the Yamen, solicit an audience and prostrate themselves before the great man, to thank him once more for what he has done in their behalf and in that of the deceased. The pecuniary part of the business being in the meantime arranged by their respective servants.

The mandarin who sacrificed to the divinity of the Soil, and he who carried the soul streamer, also receive presents in silver and, in many cases, a visit of ceremony is paid them. If any of these magistrates should happen to be on such good terms with the family that they cannot expert him to accept silver, articles of value are presented to him instead, especially edible bird's-nests, which are held in high esteem by the notables. Silver is sent also to the graduates who were employed at the obsequies; these gentlemen are at the same time presented with a piece of red cloth and a couple of gilt flowers, such articles not having been presented to them sooner, as in the case of the mandarins. And to the grandee who allowed the family to make use of his exalted name and titles for the soul streamer, the mourners send, besides a present of coined or uncoined silver, the mail piece of silk bearing his name, which, as we have seen on page 212, was torn from the streamer before the latter was deposed in the grave : he may now feel convinced that the burial will do no harm to his personage.

Finally it remains to be mentioned that gifts are also forwarded to those friends and acquaintances who followed the dead man on his way to the 


\section{The religious system of China}

vol. I

grave, or added glory to the funeral procession by sending auxiliary pavilions. The latter generally receive a ham, this being considered to be the best portion of a pig, as also some red cakes of flour, incense-sticks, mock paper money and a few tapers, the total value of which articles being about equal to the expenses they have incurred. The rule is, that every one who receives presents from the mourning family should sacrifice them to the manes and lares on his domestic altar before consuming them. 


\section{The religious system of China \\ vol. I}

\section{CHAPTER IX}

\section{The relationship between ancient and modern funeral rites. Final remarks}

p.235 Our description of the way in which the Chinese of Amoy dispose of their dead, has introduced the reader to many practices already mentioned in literary remains which have been handed down as valuable relics of what may be said to represent the most ancient historical epoch of the Chinese empire. That these practices still are in as full vigour as they were during the age of Cheu, is undoubtedly due, in the first place, to the influential position which the said documents have always occupied in Chinese society during the whole range of dynasties that have borne sway over the realm. Even if we give the fullest weight to the idiosyncrasy of the nation slavishly to imitate what previous generations have done, it can scarcely be denied that few, perhaps none of the practices in question would have outlived the ravages of time, had not the ancient books preserved the knowledge of them to posterity.

It may be admitted as a matter beyond dispute that the house of Han adopted by simple tradition many of the official rites and institutions of earlier ages. The sovereigns of this house undertook the collecting and arranging of the fragments of the ancient literature, and under their auspices able scholars rescued the $I I i$, the $L i k i$ and the Cheu li from eternal oblivion. The results of their strenuous efforts to save whatever could be saved from perdition enabled the dynasty to supply many deficiencies in the rites which it had adopted as its own, and to constantly improve the same by abolishing much to which no reference was made in the documents brought to light. Subsequent dynasties framed their institutions on those of the house of Han, admitting, however, modifications of more or less import. All adopted the Classics and the Three Rituals as the fundamental constitution of the State. Instances of eminent statesmen presenting memorials to the throne as how to interpret, how to practise sundry rescripts contained p.236 in these books abound in the historical works, which circumstance gives us a right to surmise 


\section{The religious system of China \\ vol. I}

that formal codifications of the rites have always been in existence since the house of Han.

As a matter of fact some of these codifications have been preserved in the earlier Dynastic Histories under the title 'Records of the Ritual', but it is not possible now to decide whether in their entirety or in an abridged shape. None of them equal in elaboration that of the Khai yuen period, to which we have had occasion to refer on page 224 . This complete compendium of the statutory rites enacted by the Thang dynasty, or, as we may call it, fundamental code embracing all the rescripts relating to the State Religion at that time, is a regular synopsis. of nearly all the ceremonial usages mentioned in the ancient books, with a few additional elements borrowed from the house of Han. It was drawn up by the statesman Siao Sung, assisted, as we may surmise, by a body of officials and scholars. The extracts from it contained in the 'General Canon', Thung tien, of Tu Yiu ( $9^{\text {th }}$ century), and in the 'Thorough Investigations of Memorials', Wen hien thung khao, of Ma Twan-lin ( $14^{\text {th }}$ century), are so numerous that there is scarcely any room for doubt these comprehensive thesauri supply us with the codex in its entirety. Under different headings it is also distributed throughout the Canon of Rituals, which is one of the sections of the giant collectanea Ku kin thu shu tsih ch'ing already referred to several times in this work.

The Khai yuen Codex, commonly known as Khai yuen li, 'Ritual of the Khai yuen period', is the medium through which the most ancient ceremonial usages of China have ever since held a place as the standard institutions of the empire. In it the manners and customs of the pre-Christian period, for so far as posterity possesses written evidence of the same, were collected, under a systematic arrangement and thus, we may say, crystalized into a solid body of political, social and religious statutes which have borne undisputed sway over the empire down to the present day. The comprehensive compilations of the institutions of the Ming dynasty and of the present house of Ts'ing, known respectively p.237 as Ta Ming hwui tien, 'Collective Statutes of the Great House of Ming', and Ta Ts'ing hwui tien, 'Collective Statutes of the Great House of Ts'ing', were, so far as the rites and ceremonies are concerned, moulded on it. It is also the prototype of the Ta Ts'ing thung li or 'General Rituals of the Great Ts'ing dynasty', which is an extra codification of the rites proper for the 


\section{The religious system of China}

vol. I

use of the nation, published in obedience to a rescript promulgated in 1736 by the emperor Kao Tsung.

As in the Khai yuen Codex, one section in this Ta Ts'ing thung li is devoted to the so-called hiung li or Funeral Rites. This gives elaborate regulations for the disposal of the dead, from the Son of Heaven and the members of the imperial family down to the several classes of nobles and officials and even to the common people. These rescripts, which we shall deal with in detail when describing the religion of the State, are also widely made use of as rules of conduct by notable families in which titulary dignities have been purchased for money. Already on pages 50 and 164 we had occasion to state that buying official titles is a thing of every day occurrence in the Empire of the Midst. Besides placing the family beyond the reach of rapacious mandarins and inimical fellow-citizens, an official title possesses the enviable advantage of securing to the purchaser, his parents and wife a very honourable position in the next world, being conferred by the Son of Heaven, the second personage of the universe and, as such, the chief of gods and spirits (comp. page 220). Their deceased persons ought accordingly to be dispatched to those invisible abodes with all the honours due to the high rank they are going to assume there, that is to say, with observance of the ritual established for each dignity and rank by the Sons of Heaven themselves and laid down in the aforesaid General Rituals. Now, as these Rituals are a mere digest of the ceremonial usages contained in the ancient works, we have here an explication of the fact set forth at the outset of this chapter, that so many practices now-a-days connected with the disposal of the dead are directly traceable to antiquity.

There is still a second reason which accounts for this phenomenon. Chu $\mathrm{Hi}$, the most eminent among the modern philosophers and ethical authors of China, in the $12^{\text {th }}$ century compiled p.238 a work entitled Kia li, 'Rituals for Family Life', which, having been elaborately commented upon by scholars of repute, has ever since circulated throughout the empire as a standard authority. It has even been deemed worthy of a place amongst the writings from which the General Rituals of this dynasty have been built up. A passionate partisan of the orthodox doctrine that social institutions ought to be based on precedents established by antiquity, a doctrine which has ever reigned supreme in the empire, $\mathrm{Chu} \mathrm{Hi}$ made his work a mere digest of 


\section{The religious system of China \\ vol. I}

rescripts laid down in the Classics, especially in the $I$ li and the Li ki. Though eliminating many points which had evidently fallen into disuse in his time, on the other hand he adopted much which is not spoken of in the ancient works, thus sanctioning many a custom not purely classical. Of these we may mention the strewing of ashes of wood in the bottom of the coffin (p. 89) and the moving and transporting the receptacle of the dead by means of ropes wound around it. After the coffining, this author says, one should set up a 'bed for the soul' on the east side of the coffin, with a mat, a pillow for the head, clothing, coverlets, a standing screen, etc., such as were used by the deceased during life. Though we have never found this precept mentioned in the ancient books, nor have we seen it put in practice by the Amoy people, yet, in consideration of the important part which the Kia li plays in family life, we can scarcely doubt that it is conformed to in many parts of the empire, because it is evidently closely connected with the sacred custom mentioned on page 119 of providing the deceased every morning with washing water, towels and other necessaries for his toilet. Szĕ-ma Kwang, the famous statesman, historiographer and author of the $11^{\text {th }}$ century from whom many wise judgments are incorporated with the Kia li, sanctions the non-classical custom or placing a painted portrait of the dead behind the provisory tablet (comp. p. 113), but rebukes the custom of having such portraits, made for females, declaring it inconsistent with correct rites to expose the face of a deceased member of the weaker sex to the profane view of a painter. The Kia li also prescribes the appointment of a 'patron of the funeral rites' (page 112). In the Classics we find no such persons mentioned, but we come across them in the Books of the Early Han Dynasty, chapter 68 of which work p.239 relates on leaf 12 , that half a dozen of them were appointed by the emperor to officiate at the obsequies of the famous statesman Hwoh Kwang, who died in 68 B. C. Moreover, we are told in the Books of the Later Han Dynasty, that Ch'en Tsun, a Provincial Governor in the first century of our era, « acted in his own person as patron of the obsequies of one of his friend's parents ». Besides these two passages relative to the function, we have found others in these histories. Finally, Chu Hi advocates the covering of the coffin with lime and similar substances which in course of time coagulate into a solid mass and thus protect the dead against grave-robbers, ants and the roots of 


\section{The religious system of China}

vol. I

surrounding trees. He likewise prescribes the placing in the tomb of the five cereals (p. 209), without, however, saying they serve to ensure abundance of food to posterity.

On the other hand, the Kia li is perfectly silent on some usages which, although they are not traceable to the books of antiquity, pass now-a-days for rites of most indisputable import. Not a word does it say on the dotting of the tablet, but it teaches that a part of the inscription should be written upon it at the grave : a precept which we may be sure is still followed by many an orthodox family. Neither does the book make mention of a sacrifice presented to the soul at the side of the grave. Buddhist ceremonies, of whatever sort or tendency they may be, it stigmatizes without reservation as heterodox and therefore unbecoming any true son of China. A lengthy note from the hand of Szĕ-ma Kwang is here subjoined, showing how utterly false the doctrines are on which Buddhism bases its rites of redemption, a note to which we shall have occasion to refer more particularly in our Book on that Church.

So far for the close relationship between the modern funeral rites and those of antiquity. We must now pass to another point worthy of notice, viz., that the ceremonies observed on the death of a woman are conducted in the same manner and style as in the case of her husband. In the first place this is owing to the stringent rule, sanctioned also by Chinese legislators as one of the principal laws of social life, that children owe their mother the like amount of devotion, respect and submission (hiao, see p. 120) as they do their father. Moreover, whenever a man is endowed with an official p.240 degree or dignity, a corresponding rank and title is at the same time conferred upon his consort, the Government having adopted the principle of the $L i k i$ (ch. 54, I. 18) that

«A woman generally gets titles and rank along with her husband (191).

Thus she naturally acquires a right to be seen away to the next world with the ritual established by the State for her husband's rank.

Considering that in China the disposal of the dead is almost exclusively based upon the doctrine of implicit devotion to husband and parents, it is quite natural that boys and girls, and in general people who leave neither wife nor offspring behind, should be buried with a minimum of ceremony and 


\section{The religious system of China}

vol. I

pomp. Such was the prevailing rule already in the time of Confucius, as may be inferred from the following episode related in the $L i k i$ (ch. 13, I. 37) :

«In the battle at Lang (B. C. 484) Kung-shuh-yü-jen advanced along with Wang I, a youth of his neighbour, and both were killed. The men of Lu, desirous of treating the lad as one who had died not under age, questioned Chung-ni (Confucius) on the matter, and the latter laid: "He has proved himself able to bear shield and spear in defence of the gods of Land and Grain ; why should not you then be allowed to do as you desire? (192)

The same incident is recorded in the Tso ch'wen, under the heading : ' $11^{\text {th }}$ Year of the ruler Ngai'.

Our description of funeral rites is in no case applicable to the clergy of the Buddhist Church, nor to the numerous eclectical sects based on Buddhist doctrines, which exist in many parts of the empire. These people have mostly a set of funeral ceremonies of their own; cremation is even practised amongst them on a very large scale. Their principal observances at deaths we shall review in the chapters specially devoted to the same in our Book on Buddhism. 


\section{P A R T I I \\ THE I DEAS OF RES UR RE C T I O N}

p.241 The funeral rites described in the first part of this Book sufficiently establish the fact that the Chinese regard death as a separation of the vital spirit from the body, and that they cling to the belief that the spirit keeps hovering about the body, even after the latter has been deposited in its final resting place. We need only remind the reader of the light placed at the side of the corpse while it is stretched on the 'water-bed' (p. 21 seq.); of the frequent calling to the dead, for the purpose of inducing the wandering duplicate to re-enter the mortal remains and bring these to life again (p. 10 seq.); of the tablet placed near the corpse for the occupancy of the soul ( $p$. 71); of the offerings of edibles set out on the spot (p. 29, 70 sqq.) ; of the tablet, pennons and portrait harbouring the soul, which are carried along in the funeral procession and for a part deposited with the coffin in the grave, with the avowed object of there installing the soul with the body (p. 212 seq.); of the numerous practices for surrounding the corpse in the tomb) with influences which may enable the soul to deal out blessings to posterity ; and so forth.

The Chinese are therefore far from regarding death as an absolute reality. Life remains after the soul has left the body ; the survivors even entertain a lingering hope that the soul may re-enter the clay and thus cause resurrection to take place. Taking for granted that the accumulated experience of ages has done something to establish among the people a notion of the reality of death, it is not beyond the pale of logic to conclude that the belief that the soul does not forsake the body, either before or after interment, and that it may recall it to life, must have borne a more potent sway over the Chinese mind in times gone-by than it does at the present day. For the correctness of this conclusion we have p.242 abundant and direct testimony in the written 


\section{The religious system of China}

vol. I

documents of the empire. Numerous customs and practices having an important influence in the domain of religious and social life have been called into existence by this belief. To review them in both their ancient and modern aspect will be the chief object of this and the next part of the present Book. 


\section{The religious system of China}

vol. I

\section{CHAPTER I \\ Calling back the soul. The death-howl}

\section{Recalling the Soul.}

p.243 It is a well-established ethnographical fact that savage and semicivilized man as a rule explains sleep, swoon and unconsciousness as due to an absence of the sentient entity from the body. The invisible duplicate thus wandering away may be made to return to the body by shouts and by calling out the name. Sometimes, as in ordinary sleep, it comes back immediately. In other instances, as when the body is in a state of lethargy or trance, the return of the other-self is postponed for hours, at times for several days. Yet, in most cases, re-animation does actually take place.

Similar conceptions are entertained by the Chinese. At Amoy, they say of one who is in a fainting fit that 'his soul is not united with his body' : sin put $h \bar{u}$ thé. And when a baby is taken with convulsions, the affrighted mother finding her first attempts to coax her darling back to consciousness by repeatedly calling out its name to be in vain, she hastens up to the roof of her house and, waving about a bamboo pole to which is affixed a garment belonging to the little one, exclaims several times in succession : « My child So-and-so, come back, return home ! » In the interim another inmate of the house is loudly beating a gong, to arouse the attention of the soul. After a while the vital spirits are expected to recognize the garment and to slip into it ; and so, along with it, they are taken back to the sufferer and placed either upon or at the side of his bed. If recovery does not follow in a few minutes, it is a proof the soul has not yet returned. The mother once more repairs to the roof of the house to repeat the same ceremony, and, if necessary, she does so over and over again, until her efforts are crowned with success. Chinese people in general. believe that p.244 convulsions and fits are in most cases due 


\section{The religious system of China}

vol. I

to a certain class of mischievous spectres, who are fond of drawing the vital spirits out of men : In the case of babies and children, these unseen beings are, at Amoy, designated as the tsaó bé thien-kong, 'celestial agencies bestriding galoping horses', and as the poàn thin siù-tsâi, 'literary graduates residing halfway up in the sky'.

Similar attempts to bring back the other-self are resorted to in case a fullgrown person suddenly sinks down in an inert state and betrays a total loss of feeling and consciousness; also when any one is taken ill or dying, sickness, especially if coupled with unconsciousness of mind, being likewise regarded as a sign of the absence of the soul. Under such circumstances, people hurry to a priest of the class mentioned on page 107, that he may, as they call it, 'snatch the vital spirits away', ch'ióng tsing-sîn, in other words, rescue them by certain ceremonies from the claws of the invisible being who has stolen them from the body. In another Book these ceremonies will be described in detail.

Primitive man, having witnessed various durations of insensibility followed in many cases by re-animation, on beholding a body lying in a state which we are accustomed to call death, would naturally confound its condition with ordinary syncope and infer that the other-self might possibly return to it. He would still entertain this hope even when the body grew cold, nor would he relinquish it when decay set in. The persistence of the insensibility would prompt him to make more strenuous efforts to bring the soul back, to shout, call and speak to it louder and longer than he would do in case of unconsciousness of a less grave nature ${ }^{1}$. In China we find p.245 the nearest

1 This has been illustrated already on page 11 by some instances taken from the customs of savage tribes. Here are a few more examples:

«When one died among the Romans, the nearest relatives embraced the body, closed the eyes and mouth, and when one was about to die, received the last words and sighs, and then loudly called the name of the dead, finally bidding an eternal adieu. This ceremony of calling the deceased by name was known as the conclamation, and was a custom anterior even to the foundation of Rome. In Picardy, as late as 1743 , the relatives threw themselves on the corpse, and with loud cries called it by name. - Among the Yo-kai-a Indians of California, a mother who has lost her babe goes every day for a year to some place where her little one played when alive, or to the spot where the body was burned, and milks her breasts into the air. This is accompanied by plaintive mourning and weeping, and piteous calling upon her little one to return. - The Caribs lament loudly, their wailings being interspersed with comical remarks and questions to the dead, as to 


\section{The religious system of China}

vol. I

relations behaving in this way even at the present day (see p. 10), repeating their lamentations over and over again during the funeral rites. Kao Khang, who lived in the $12^{\text {th }}$ century, records the following custom of the inhabitants of Hwai-nan, i. e. the central part of the provinces of Nganhwui and Kiangsu :

« Now-a-days, in Hwai-nan, it is customary when any one among the people has died suddenly, to send a certain number of men on to the roof of his dwelling and along the roads, to call for the deceased everywhere. Some have in this way been resuscitated (193).

As we may naturally suppose, the custom of calling back the dead was highly developed in China in olden times. Confucius cherished the conviction that it prevailed there already at the dawn p.246 of civilization, for, according to the $30^{\text {th }}$ chapter of the $L i k i(I .20)$ he said :

«When ceremonial usages were coming into existence, people, in case of death, went up to the housetop and exclaimed : "Ho. o. o. So-andso, come back!" (194).

why he preferred to leave this world, having everything to make life comfortable. And Roman, in his History of Florida (1775, page 88 ) relates that, among the Choctaws of Carolina, as soon as the deceased is departed, a stage is erected and the corpse is laid on it ; at this stage the relations come and weep, asking many questions of the corpse, such as why he left them ? did not his wife serve him well ? was he not contented with his children ? had he not corn enough ? did not his land produce sufficient of everything ? was he afraid of his enemies ? etc. » First annual Report of the Bureau of Ethnology to the Secretary of the Smithsonian Institution, pp. 166, 194, 168.

«Camden's Britannia, dealing with ancient and modern manners of the Irish, records: "When a person is at the point of death, just before he expires, certain Women Mourners, standing in the Cross-ways, spread their hands, and call him with cries adapted to the purpose, and endeavour to stop the departing soul, reminding it of the advantages it enjoys in goods, wives, person, reputation, kindred, friends, and horses: asking why it will go, and where, and lastly, complaining that the departing Spirit will be transformed into those forms which appear at night and in the dark : and, after it has quitted the Body, they bewail it with howlings and clapping of hands. They follow the funeral with such a noise, that one would think there was an end both of living and dead. The most violent in these lamentations are the Nurses, Daughters, and Mistresses. They make as much lamentation for those slain in battle, as for those who die in their beds, though they esteem it the easiest Death to die fighting or robbing; but they vent every reproach against their enemies, and cherish a lasting deadly hatred against all their kindred". Similarly in the Statistical Account of Scotland (1793) we read of the parish of Nigg in Kincardine : "On the sudden Death of their Relations, or fear of it, by the Sea turning dangerous, the Fisher people, especially the Females, express their sorrow by Exclamation of Voice and Gesture of Body, like the Eastern Nations, and those in an early State of Civilization". » - Brand, Observations on Popular Antiquities, Customs at Deaths. 


\section{The religious system of China}

vol. I

The $L i k i$ gives also very valuable particulars connected with the custom as it was practised in the pre-Christian era. In its $57^{\text {th }}$ chapter (I. $5 \mathrm{sqq}$.) it has :

«In calling back the dead, if there are forests and thickets in the territory, the foresters arrange the steps, but if there are no woodlands, the serfs do so. The calling back is done by an officer of low rank, who uses the court dress of the defunct... In all cases he ascends by the corner on the east, advances to the middle of the roof where it is dangerous to stand, and, turning his face to the north, there shouts to the dead three times. Then rolling up the dress, he casts it down in front, where the Officer in charge of the Official Dresses receives it, after which he descends by the corner on the north west.

In case the deceased is a visitor from another country, his soul is called back in the mansion of the head of the State, not in a private house. If he dies in the open country, they call his soul back standing on the left wheel of his carriage.

The garments which have been used in calling the dead back, are not used for dressing the corpse, neither for the second nor the third dressing. In calling back the soul of a woman her wedding garments are not used. Whenever a soul is called back, a man is called by his personal name, a woman by her title. Nothing but howling precedes the calling back. The calling finished, they perform what is required in cases of death $(\underline{195})$.

In calling back the soul of the Son of Heaven, they exclaim : p.247 "Come back, O Son of Heaven!" (chapter 6, I. 50) (196). In calling back a feudal prince, they say: "Return, Sir So-and-so" (ch. 7, I. 32) (197). In calling the soul back and in writing the soul banner ${ }^{1}$ the same terms are used for all, from the Son of Heaven down to ordinary officials. A man is called by his personal name (ch. 46, I. 6) (198).

It will be seen from the above extract that a suit of the deceased was made to play an important part in the ceremony. It must be his court dress,

\footnotetext{
${ }^{1}$ See page 174 sqq.
} 


\section{The religious system of China}

vol. I

the principal costume he possessed and which therefore was dearest to him ; chapter 53 of the Li ki (I. 25 sqq.) moreover says :

« In the case of a feudal lord, in calling back the soul they use the dress of his investiture, also that worn with his crown and with his official cap or his cap of leather. In the case of his wife, they employ the black robe and that embroidered with pheasants, both lined with plain white silk. In calling back the consort of a grandee, they take her aster-coloured robe and the robe of her investiture, lined with plain white silk; in recalling the wife of a Great officer of lower rank, they make use of an unornamented dress. For all other women the same garments are used as in the case of the consort of an ordinary officer (199).

Though our knowledge of the garments anciently worn by official persons is very meagre, yet there is scarcely any doubt that the dresses mentioned in this extract were special uniform attires connected with the dignity and rank of the persons to be recalled. It is, indeed, quite natural that the use of such dresses should have been preferred in alluring the soul, since it would feel particularly inclined to slip into such of its garments as it had been proud to wear during life. Kia Kung-yen, a renowned p.248 commentator on the ancient books who lived in the $7^{\text {th }}$ century, says :

« They used the clothes he was wont to wear during his lifetime, supposing that the vital spirits, on recognizing them, would re-enter them and seek refuge therein (200).

In the end they were placed upon the body, just as is done at the present day in the case of a sick person or one who has fainted (page 243). This we may learn from the $I l i$, whose account of the way in which the calling back was performed at the death of ordinary officers, their parents and wives, runs as follows :

«A person charged with calling back the soul takes the dress which was worn by the defunct with his official cap or his cap of leather, and fastening the petticoat to the coat, he hands both over his left shoulder, putting the collar into his girdle. Ascending by the eastern corner of the gable-front of the building, he advances to the middle of 


\section{The religious system of China \\ vol. I}

the roof, turns his face to the north and holding the clothes, he calls the soul, exclaiming : "Ho. o. o. So-and-so, come back!" He holds the collar of the court dress in his left hand and the waist in his right, and, whilst calling, moves his hands to the left side (201). Having ejaculated his exclamations three times, he lets the clothes down by the frontside of the building; they are received in a basket and taken up the eastern steps, to be placed upon the dead body. The man who called the soul then descends at the back of the house, by the western corner (202).

The garments, the Khienlung editors add, were received in a basket because the soul had taken shelter in them, therefore people of low rank were not permitted to receive them in their hands; this was a mark of care, of respect.

As the above extract shows, the men who performed the calling back p.249 ascended the roof by the eastern corner of the gable-front and descended at the back of the dwelling, on the west side; in other words, as ancient buildings usually faced the South (see page 5), they went up at the southeastern corner and came down by the north-western. No doubt this manner of proceeding was prescribed by the knowledge that the East and South, or the regions where the sun rises and reaches its highest power, were specially assimilated with the Yang part of the Universe, the great source of all life in Nature, while the West and North, where the sun sets or never appears, were associated with the Yin part, i. e. with darkness, cold and death (comp. page 22). The learned Khung Yiug-tah says :

«Calling back the soul immediately after death was an attempt at finding back the life of the deceased; hence the man who had to do the calling ascended by the eastern wing. But, after having tried in vain to find the soul, he felt averse from going back without having gained his object ; hence he proceeded in the direction of the dark Yin and then went down from the house (203).

The assimilation of the North with Yin and death also explains why the dead was called from this region, as both the $L i k i$ and the $I l i$ have told us. 


\section{The religious system of China}

vol. I

«Calling back the soul, says the Li ki (ch. 12, I. 21), is the way to manifest one's love and affection in all their fulness ; it partakes of the character of a prayer. To look for their return from the region of darkness is the right way when seeking for disembodied spirits in general ; hence the custom of turning one's face to the North in calling back a soul signifies that it is sought for in those dark regions (204).

The West being likewise a part of the great domain of the Yin, the man who called the soul held the clothes up in that direction, as is stated on the preceding page in our quotation from ch. 31 of the $I$ li ; moreover,

« it was on the west side of the others that the principal caller stood when calling back the soul (205).

This statement, which occurs in ch. 53 of the Li ki (I. 28), is doubly important, as it also p.250 intimates that in some instances more than one person was employed to perform the ceremony.

The great importance anciently attached to calling back the dead is manifest from the numerous passages in which the three Books of Rites refer to it, as well as from the fact that these passages contain very minute descriptions as to the way in which this ceremony was to be observed in peculiar and exceptional cases. So e. g., they teach us that, if the envoy of a state died on his mission, his soul must be recalled in a palace of the ruler in whose territory he found himself, and that it was strictly forbidden there to recall it in the mansions of nobles of the highest ranks.

«If an envoy of a ruler dies, says ch. 54 of the $L i k i$ (I. 22), his soul is called back in the mansion of the head of the State, not in any private mansion. By a mansion of the head of the State is meant his palace, or some other building erected by him ; a private mansion is the dwelling of a nobleman, a Great officer or a person below these in rank (206).

According to ch. 27 of the $\mathrm{Li}$ Ki (I. 39) this rescript was on a certain occasion the subject of a discussion between Confucius and his principal disciple :

« "If, asked Tseng-tszĕ, on a commission upon which he has gone for his ruler, some one dies in the building in which he is lodged, the rites require that he shall be called back in a mansion of the head of the 


\section{The religious system of China \\ vol. I}

State, and not in a private mansion. But to whatever realm a commissioner may be sent, the building assigned to him by the officers is a mansion belonging to the ruler; why then is it explicitly declared that the calling back must not be performed in a private mansion ?" To which Confucius replied : "You have asked well, indeed. The dwellings of noblemen, Great officers and ordinary officers are called private mansions, but the hotel of the head of the state and the buildings erected by him are styled mansions of the head of the state. In this you have the explanation of the precept that the soul is recalled in the mansion of the chief of the state" (207).

p.251 There also existed rules prescribing how to act with feudal lords, noblemen and officers who breathed their last outside their residences, or on the road. It is laid in ch. 53 of the Li ki (I. 1 and 4) :

« If a feudal lord, being on the march, dies in a mansion, his soul is recalled in the way in which this is accustomed to be done in his kingdom. If he expires on the road, some one climbs on the left wheel of his driving car and calls the soul back, waving the defunct's yak's tails fastened on the top of a staff. If a Great officer or an ordinary officer dies on the road, his soul is likewise recalled by some one standing on the left wheel of the deceased man's car and waving his yak's tails; and if he dies in a mansion, he is called in the same manner as if he had departed this life in his own house (208).

The following passage occurring in ch. 11 of the $L i k i$ (I. 38) may be quoted as being of particular interest because it points to the prevailing conviction that, the longer revival absented itself, the further the soul was away, so that, in calling it back, the circle of activity must be gradually widened.

«In the case of the ruler of a state, the soul is called back in the smaller back chamber, in the larger back chamber, in the smaller ancestral temple, in the greater ancestral temple, at the gates of the arsenals and treasuries, in the four suburbs of the capital (209). 》

«The Hia-ts'ai, adds the Cheu li, when officiating at Great funerals, takes the robe which is worn with the crown and calls back the soul in the great ancestral temple; then, on the driving car on which the 


\section{The religious system of China}

vol. I

yak's tails of the defunct are erected, he calls back the soul in the four suburbs of the city (210). The Servants attending p.252 at the Sacrifices, at Great funerals call back the soul in the small ancestral temple (211), and the Assistant Servants on such occasions recall it in the smaller back chamber and in the larger one (212).

In those ancient times it seems to have been customary after battles to call back the souls of the brethern slain in arms. In chapter 9 of the $L i k i$ it is related on I. 42 , that

« in Chu-lü they used arrows for recalling the dead, a practice which had taken its rise from the battle at Shing-king (213).

This bloody conflict between the armies of $\mathrm{Chu}$ and Lu, which took place in the year 637 or 638 B. C., is recorded in the Tso ch'wen, under the heading : 'Twenty-second year of the ruler $\mathrm{Hi}^{\prime}$; those of Chu carried the day.

« Notwithstanding their army then remained in possession of the field, says Ching Khang-ch'ing, the number of their slain and wounded was very great, and they had no clothes wherewith to call back their souls.

« The men of Chu, adds Khung Ying-tah, having set their minds upon carrying the day, they had taken their arrows closely to heart. Hence the victors, in calling back the souls, availed themselves of these arrows on which the slain had been so bent, in hopes the souls might be brought back by the same.

The various extracts reproduced in the preceding pages acquaint us with a practice which, having arisen undoubtedly in savage times, had gradually assumed the shape of a rite of generally acknowledged import, of a rite which, during the Cheu dynasty, was to be performed for everybody without exception, from the Son of Heaven down to the slain on the field of battle. It was then regulated by minute rescripts, nay, even commended « as the way in which one's love and affection for the dead might be manifested in all their fulness » (see. p. 249). Such great importance p.253 being attached to it already in early ages, we certainly need not be surprised that calling back the dead has not yet died out in a realm, where absolute devotion to parents has always been proclaimed as the duty standing above all others, and where the 


\section{The religious system of China \\ vol. I}

written remains of antiquity have ever been regarded as authentic codes of morals. The literature of the empire affords abundant evidence that the practice in question has obtained throughout all ages both amongst the ruling classes and the common people as a sacred custom. It would carry us too far from our subject to pass in review the numerous extracts lying before us in which reference is made to this rite. We must confine ourselves to a few short notes.

Yen Chi-thui, the ethical writer of the sixth century whose work has been quoted on page 42 , ordered his children « not to take the trouble to call back his soul ». The Codex of the Khai-yuen period formally sanctioned the ceremony as part of the funeral rites of the official classes, prescribing that it should be performed by three men, successively in the back chamber and on the roof of the building, with observance of the rules laid down in the $I / i$ and the $L i k i$. But in the case of officials under the fourth degree and other people, the calling back was to be done by two persons only. During the reign of the house of Sung, the recalling of the dead obtained as a custom in Hwai-nan country, as we have seen from Kao Khang's statement reproduced on page 245. In the official obsequies of that period the temporary soul tablet described on page 70 was used in lieu of the clothes of the deceased for calling back the soul, as may be inferred from the following extract from $\mathrm{Ma}$ Twan-lin's Wen hien thung khao:

«In the $31^{\text {st }}$ year of the Shao-hing period (A. D. 1161), Kin Ngantsieh, Vice-President of the Board of Rites, with some others memorialized as follows. "Scrutinizing the Collective Statutes of the empire, we have made earnest inquiries into the rules relative to the temporary soul tablet; and we have arrived at the conclusion that, although no direct references to it are to be found in the Classics, yet this tablet can be traced back to ancient times, it being based upon the ideas connected with the custom of calling back the dead. Indeed, the $L i$ yun (ch. 30 and 31 of the $L i k i$ ) informs us that, when a case of death occurred, people went upon the roof of the house and there exclaimed : 'Ho. o. o. p.254 So-and-so, come back!' (see p. 246). Upon this practice is based the ancient custom of recalling the dead with his 


\section{The religious system of China \\ vol. I}

clothes, as well as the present custom of doing it with the temporary tablet" (214).

The reader will probably remember that the calling of the other-self into a temporary soul tablet inscribed with the name etc. is still performed now-adays through the intervention of a Buddhist priest (see page $71 s q q$.). The ancient method of climbing upon the house top has fallen into disuse at Amoy, in spite of Chu Hi, who formally prescribes it in his Rituals for Family Life. It appears that it had already become obsolete in the $11^{\text {th }}$ century, as Szě-ma Kwang then wrote :

«At present people fear to alarm the community if they ascend the house and shout there. Hence they merely repair for such purpose to the south side of the back chamber and of the court-yard (215).

\section{The Death-howl}

"Calling the soul back", it is said in chapter 12 of the $\mathrm{Li} \mathrm{ki,} \mathrm{"bears} \mathrm{the}$ character of a prayer" (see p. 249). This statement implies that, during the Cheu dynasty, the departed spirits of the dead were wailingly addressed in coaxing terms to induce them to revive the corpse, as is still the case at the present day (comp. p. 10). It also suggests to us that a connection exists between the recalling of the dead and the methodic lamenting to which the modern Chinese give themselves up at some important moments of the funeral rites, a lamenting which has, through all ages, obtained in Chinese life as a sacred rite regulated by minute rescripts and well defined customary rules. We do not hesitate to say, that at one time both rites were probably one and the same thing. p.255 This is decidedly confirmed by the statement of the $L i k i$ reproduced on page 246, that "nothing but howling preceded the recalling of the soul".

Bearing in mind the fact sufficiently established in the foregoing pages of this chapter, that recalling the dead anciently held a place in China as a ceremony of the greatest import and as a sacred rite which nobody might 


\section{The religious system of China \\ vol. I}

presume to neglect, our theory then fully explains why in those same ancient times a place of no less importance was assigned to the death-howl. Though in process of time the original signification of the howling has been lost sight of, and it now merely survives as a formality betokening grief and woe, yet the fact remains that it has never lost its position as a rite of as much significance at least as the recalling of the dead; and this fact, we venture to say, cannot be accounted for except by concluding that the two practices are intimately connected, and identical in origin.

It is now incumbent upon us to prove by documentary evidence that the recalling of the soul and the death-howl were rites of equal weight in ancient China, and at the same time to bring forward such points as indicate that these two ceremonies are virtually linked together by ties of the closest relationship. With the help of the invaluable $L i k i$ it will not be difficult to accomplish this task. This Classic shows that, like the recalling of the soul, so the death-howl was observed for everybody, from the emperor downwards ; princes even wailed for members of their family who had expiated crimes under the executioner's hands. Chapter 9 has on leaf 28 :

« Teng tszĕ said : "The sorrow displayed by the wailing and weeping, the feelings expressed by the deep mourning garments, and the food of congee and rice, extend from the Son of Heaven to all" (216).

And ch. 29 relates on I. 26 :

«When a kinsman of the Ruler's had committed a crime, the Ruler did not offer condolence, wore no mourning and wailed for him in a temple of people of another surname, because he kept the man who had disgraced his ancestors aloof from the latter (217).

This passage showing that the ancestral temple was selected as a place for p.256 performing the death-howl, confirms the supposition that this was intended to cause the soul to return, for indeed, one must have naturally wished the dead man to take up his abode with the spirits of his ancestors in the place of worship specially dedicated to them all. The formal recalling, as we have seen from authentic passages quoted on page 251 , took place in the ancestral temples in point of fact. Chapter 10 of the Li ki moreover has (I. 12) : 


\section{The religious system of China \\ vol. I}

«Poh-kao having died in Wei, news of the event was sent to Confucius. He said : "Where shall I wail for him ? For a brother I wail in the ancestral temple, for my father's friend outside the temple gate, for a teacher in the back chamber, for a friend outside the ts'in gate, for an acquaintance in the field. If I now wail in the open field, I behave as if there existed only a remote relationship between us; if I do so in the back chamber, I make too much ado about him" (218).

We see from this that the death-howl was performed in exactly the same places as the formal calling back of the soul (comp. p. 251). The close relation between the two rites is further manifest by the fact that people were accustomed to wail also on the tombs, that is to say, on the very place where the body lay which it was desired to resuscitate. According to ch. 13 of the Li ki (I. 39), Yen Yuen, a disciple of Confucius, said to Tszě-lu, his father, who was also a disciple of the sage :

«I have been taught that, on leaving the country, one wails at the grave before starting, and that, on returning, one goes to look at the graves without wailing and then enters the city (219).

Finally it is deserving of attention that, in ancient times, those who wailed for a person who had recently died repeatedly placed their hands on the corpse, pulled at its clothes and leaned over it, the greatest amount of enthusiasm being displayed by those whose relationship was closest. This practice - on which we expatiated on pages $37 \mathrm{sqq}$. by quoting extracts from the $\mathrm{Li} \mathrm{ki}$ and

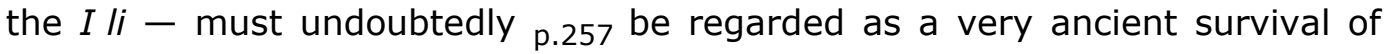
barbarous attempts to resuscitate the dead by shaking them while speaking to and shouting at them.

The fast set forth by the extracts we have quoted, that fixed spots were assigned with great minuteness for performing the death-howl sufficiently demonstrates the high importance in those times attached to this rite. Also the various moments at which it was to be set up and to be stopped during the funeral ceremonies were objects of the strictest attention and were regulated by most minute rules. Of this the reader may convince himself by consulting various extracts from the $I$ li already quoted and still to be quoted in this volume, and also by perusing Professor Legge's translation of the Li Ki, 


\section{The religious system of China}

vol. I

especially the $70^{\text {th }}$ chapter, which contains elaborate precepts to be observed when performing the mourning rites for a near relative who has died at a distance. There are even precepts fixing the length of the period during which the howling was to be kept up :

« For the Son of Heaven, says ch. 70 of the Li ki (I. 23), they wail nine days, for a feudal prince seven, for a nobleman and a Great officer five, for an ordinary officer three days (220).

And ch. 9 (I. 18) adds :

« Tseng tszĕ declared that, when on the tomb of a friend there are shrubs of one year old, one should wail for him no more (221).

Finally the same chapter (I. 54) has :

« When the mother of Poh-yü (Confucius' son) died, he still wailed for her after the year had elapsed. The sage, hearing him, asked : "Who is it that is thus wailing ?" "It is Li", answered the disciples. The Master hereupon said : "Oh, he exaggerates the matter!" When Poh-yü heard this, he forthwith gave up wailing (222).

The importance attached, in ancient China, to the death-howl is, however, illustrated by nothing so well as by the fact that we have instances in the $L i k i$ of persons exaggerating it in a way actually bordering on fanaticism. Chapter 10 (I. 18) relates that Kao Tszě-kao, a disciple of Confucius,

« when engaged in the mourning p.258 rites for his parents, wept tears of blood for three years without ever showing his teeth (i. e. without ever laughing), and that excellent people held this to be very difficult... And (I. 15) Tszě-hia having lost his son, destroyed his eyesight. When Tseng-tszĕ came to condole with him, he said: "O Heaven, and I have no guilt!" Upon this Tseng-tszĕ got angry and exclaimed: "How, Shang, you have committed no mistakes ?... At the death of your son you destroy your eye-sight, this is your third offence. How can you say that you have no guilt ?" (223)

Since the principal disciple of Confucius' school thus sharply rebukes a fellow disciple for such exaggeration of the howling, we may infer that their 


\section{The religious system of China}

vol. I

Master was disposed in favour of moderation on the point. As a matter of fact he preaches the golden mean.

«In Pien, says chapter 10 of the Li ki (I. 53 seq.), there were people who, at the death of their mother, wept like children. Confucius said : "Such grief is grief indeed, but it would be difficult to persist in it. The rites are institutions which require to be handed down and to be observed with persistency; hence there should be moderation in howling and in stamping the feet". (224)

On the other hand the sage showed himself fully impressed with the importance of the howling as a rite, manifesting an anxiety lest it should fall into disuse; at least, the same chapter of the Li ki (I. 37) reports that his disciple

« Tszĕ-lu said : "I have heard the sage declare that, in the rites of mourning, insufficient grief with a superabundance of ceremonial is not so good as an insufficient ceremonial with an excess of grief". (2225)

The death-howl being in those ancient times thus minutely regulated by precepts with regard to time, place and duration, it p.259 follows that it had then already become a studied rite and was no more than an artificial expression of grief, mere affectation, genuine Irish weeping. Apart from nearly all the extracts quoted in the above pages, we have incontrovertible evidence of this in the following passage, occurring in ch. 71 of the $L i k i$ (I. 3) :

« The howling of one who wears the deepest mourning is as if breath were constantly emitted without returning (in other words, it is without the slightest intermission). That of one wearing the mourning of the second degree is as if breath were alternately exhaled and inhaled. In the third degree one sobs after every three dirges, and in the fourth or the fifth degree it is allowed to lament. In this manner grief is manifested by the modulations of the voice. (226)

In the Cheu li we read amongst the instructions of the Master of Collocation mentioned on page 20, that 


\section{The religious system of China}

vol. I

« at Great funerals he orders the titled ladies whether or not belonging to the royal house, to set up the death-howl in turns ; (227)

besides this one, there are many more precepts in the same codex which show that much howling was done by command, but it is superfluous to quote them here.

In succeeding centuries people have even gone so far as to employ howlers who did not stand in any degree of relationship whatever to the dead, as the following extract from the History of the Southern Part of the Realm shows.

«Wang Siu-chi died in the first year of the period Lung ch'ang (A. D. 494). His post-mortem dispositions ran as follows: "You must not place me in the coffin with red garments. Sacrifice spirits and dried meat to me, but nothing else. People of the present age employ slaves and concubines to assist in howling right in front of the soul, but this howling should go out from the principal mourner, and it can be no generosity on your part to desire that many human voices should mingle together in a disorderly concert. If my soul possesses sentient entity, I shall laugh at such behaviour". (228)

p.260 The custom thus rebuked and ridiculed so many ages ago by a statesman of high standing still flourishes in Southern Fuhkien. There the servants and slave-girls of the house, as well as the male and female friends who remain there temporarily to lend a helping hand in preparing the corpse for the grave, occasionally wail along with the family at moments of

importance, believing that assisting the mourners in fulfilling their duties towards the dead includes assisting them in howling too. We, however, have never come across instances, either in books or in actual life, of people being hired to wail for the dead.

That the death-howl now-a-days is far from having lost its high significance as a rite is sufficiently manifest from the description of the funeral ceremonies, which constitutes the first part of this Book. Where the calling back of the soul has been proof against the ravages of time, it is not to be expected that the death-howl, which has from the very beginning stood in the closest relationship with it, should have died out. Of course its tenacity of existence is also due to the $L i k i$ and the $I l i$, which books have always been 


\section{The religious system of China \\ vol. I}

authoritative codes of morals for the empire, chiefly influencing the nation through the intermediary of the official codes of rites promulgated by successive dynasties, and by Chu Hi's Rituals for Family Life.

As many extracts reproduced in this volume show, the howling of the nearest relatives of the deceased is in the ancient books of rites very often mentioned in the same breath with a stamping of the feet, in some instances also with beating the breast. About these manners of expressing grief we have but little to say ; probably they may be also considered as remnants of savage life, when the bereaved worked themselves into a wild and ecstatic frenzy not only by screaming and howling, but also by leaping, dancing, tearing their hair and clothes. Perhaps the beating of the breast represents in a milder form the more ancient lacerating of the flesh. This supposition derives confirmation from the circumstance that, as native commentators unanimously declare, this manner of displaying grief was a special act of the women; and it is well known that, among savages, the weaker sex are particularly vehement and frantic in their grief, losing all self-control in the expression p.261 hereof. Be this as it may, the howling to revive the dead having been changed by the ancient Chinese into a formal rite, it is a matter of course that the leaping and the beating of the breast, which were inseparably connected with it, have been dealt with in exactly the same manner. Chapter 12 of the $L i k i$ (I. 27) says :

«Beating the breast and stamping the feet are the highest expressions of grief. They are restricted by fixed numbers, and there exist written precepts regulating them. (229)

The reader will remember that the $I$ li frequently speaks of a rite which it calls "a full stamping of the feet" and which, according to the commentators, consisted of three stamps thrice repeated (see page 37). Down to this day women-mourners may be frequently seen striking their breasts and waddling and tottering while wailing; but it seems that such acts are not regarded by them as formal ceremonies.

As Sir John Lubbock remarks,

« savages almost always regard spirits as evil beings. And we can easily understand why this should be. Amongst the very lowest races 


\section{The religious system of China \\ vol. I}

every other man, amongst those slightly more advanced, every man of a different tribe, is regarded as naturally, and almost necessarily hostile. A stranger is synonymous with an enemy, and a spirit is but a member of an invisible tribe. (230)

We have had already sufficient evidence in the present volume that this statement holds good of the Chinese too. On page 36 it is set forth that, in ancient China, princes, on paying visits of condolence, had themselves escorted by exorcists to shield them against the spirit of the dead. Pages 32 and 108 show that even now-a-days people entertain a belief that dangerous influences stick to every one who has called at a mortuary house. Finally, on pages 129, 155, 206 and others, facts have been adduced clearly intimating that men, and even gods, are averse from coming in contact with the dead. Consequently it cannot but be recognized as logical on the part of the Chinese to consider it dangerous to attend at other people's death-howl, as this naturally suggests the presence of the soul which is called back by it. Now it is also clear why, as the $L i k i$ (ch. 11, l. 53) says,

«Confucius detested those who howled for their dead in the open field, (231)

and why this Classic, in giving rules how to behave when hurrying to the funeral p.262 rites of relations who have died at a distance, prescribes (ch. 70, I. 2) that, "while howling, one shall avoid the markets and the Court". Formal prohibitions against howling in public seem to have been in existence during the Cheu dynasty, as the code of political institutions of this house contains a clause running thus :

«The Officer of Mouth-gags forbids screaming and crying, lamenting and uttering wailings of woe inside the capital, and prevents people from singing and pouring forth death-howls on the ways in the capital. (232)

And ch. 9 of the $L i k i(I .6)$ relates :

« Ki Wu-tszĕ - a contemporary of Confucius and, like him, a grandee of the state of Lu - had built a dwelling, at the foot of the western steps of which there was a grave of the Tu family. This family having 


\section{The religious system of China}

vol. I

asked his permission to bury a second person in that grave, he granted them leave to do so. When they entered the premises (with the coffin), they did not dare to wail, whereupon Wu-tszĕ said : "Burying two persons in the same grave is not a custom which dates from high antiquity; nevertheless, since the time of the Ruler of Cheu (the founder of the Cheu dynasty) nobody has abolished it. I have allowed them to do the principal thing, why should I not grant the smaller portion of it as well ? And he ordered them to set up their death-howl. (233)

As we had occasion to state on page 24 , the ancient conception revealed by the above episode that it was improper to howl on other people's premises is still in full sway at the present day. Nobody, however, troubles himself in the least with the question of why wailing portends ill-luck to strangers. This is a simple axiom which stands in no need of explanation. 


\section{CHAPTER II}

\section{On postponing the dressing of the dead, coffining and burial}

p.263 The belief that death is only a suspended animation and that the soul may return and recall the corpse to life, having so strongly taken possession of the minds of the ancient Chinese as demonstrated in the foregoing chapter, it is but natural that they should have systematically delayed the dressing of the corpse, put off the coffining till the dead body had reached an advanced state of decomposition, and finally deferred the burial for months, nay for years.

Chapter 70 of the Li ki says on I. 31 and 34 :

«The deceased is dressed on the third day.... When some one asks :

"Why is the dressing not performed till three days after the breath has expired ?", the answer is : "At the death of a parent, the filial sons are sad and sorrowful, and their minds are full of grief. Hence they crawl over the floor, pour forth their death-howls as if they would bring back life into the body in this way; how then can they allow the corpse to be wrested from them to be dressed for the tomb ? Therefore, when we say that the body is not dressed until the third day, this means that we wait so long for its revival. If re-animation does not follow in three days, it will not come at all, and the heart of the filial son is still more broken down. Meanwhile, the plans of the family with regard to the line of conduct they are to follow are brought to maturity, and preparatory measures as to the grave garments are taken ; moreover, the relations who live at a distance have time to arrive. These are the reasons why the sages have given a decision on the matter, making three days the rule. (234)

p.264 It appears to us that this extract fairly explains why, during the Cheu dynasty, the dressing of official persons was divided into three distinct stages 


\section{The religious system of China}

vol. I

separated front one another by an interval of time, the last clothes not being put on the corpse until the moment before it was deposited in the coffin. By this usage, which has already been mentioned on page 36 and which will be described in detail in the first part of the fifth chapter, the relatives clearly expressed the reluctance they felt to preparing a body for the grave, the resurrection of which they might at any moment expect.

Chapters 17 and 34 of the Li ki say, respectively on leaf 1 and 13 :

«The Son of Heaven is encoffined on the seventh day and interred in the seventh month. Feudal princes are encoffined on the fifth day and interred in the fifth month. Great officers, ordinary officials and the people are encoffined on the third day and interred in the third month.

Chapter 56 (I. 15 seq.) confirms a part of this statement by saying :

«An ordinary official is buried after three months, a Great officer likewise, but a feudal prince is buried in the fifth month. (235)

And in the Tso ch'wen we have :

« The Son of Heaven is buried in the seventh month, and all the feudal princes then arrive without exception. Feudal princes are buried in the fifth month, and all those with whom they have covenanted attend the ceremony. A Great officer is buried in the third month in presence of all those who hold the same rank. An ordinary official is interred when a full month has elapsed, the ceremonies being then attended by his relations by marriage. (236)

p.265 It is hard to believe that the disgusting customs with which the above extracts acquaint us, should have been maintained during the advanced state of culture of the Cheu period, nay, even then have obtained the force of established rites, unless there existed some imperative motive prompting the people to maintain them, a motive which set aside all regard for the noses and eyes of the living. The respite both in the case of the coffining and the burial was lengthened in regular proportion to the rank of the person concerned; and no wonder indeed, for, the revival of an emperor or a feudal lord being naturally considered of greater importance than that of an ordinary official, the door for re-animation was left open all the longer for 


\section{The religious system of China \\ vol. I}

them. It is also interesting to see that attempts were made to prevent decay, in order that the soul, on returning, might find the body in a fit state to be reoccupied.

« For a rider, says ch. 57 of the Li ki (I. 33), they put down a large basin with ice, for a Great-officer a corpse-basin with ice, for an ordinary officer only an earthenware vessel without any ice in it ; (237)

but, says the I li, "if, for an ordinary officer, ice is used, a corpse-basin may serve for it." Already in those ancient times the governing classes had regular store houses in which they laid up ice for use during the summer months. In ch. 25 (I. 50) and in ch. 21 (I. 18) of the Li ki we read:

« In the last month of winter ice is abundant, in waters and mares it is then thick and strong ; orders are issued to collect it, and it is carried to the stores... In the middlemost month of spring the Son of Heaven opens the ice stores with a sacrifice of a lamb, first offering some ice in the back chambers and in the ancestral temple. (238)

And the Cheu li says :

«The Ice Officers are charged with taking care of the ice. In the twelfth month of the correct p.266 year ${ }^{1}$ they give orders to cut it. At Great funerals they provide the ice required for the corpse-basins. Chapter 5, I. 30. (239)

The rescripts regulating the lapse of time after which the dressing, coffining and burial were to take place, do not seem to have borne the character of imperative laws during the Cheu dynasty. The $L i k i$ itself declares in its $57^{\text {th }}$ chapter (1. 32) that

« at the death of an ordinary officer his body was encoffined on the second day, (240)

which in China means the day following the decease; but this may be a printer's error. The Ch'un ts'iu contains instances of princes who were buried

1 That is of the year according to the chronology of the Hia dynasty. The twelfth month then corresponded to the second month according to the chronology of the Cheu period, which is still in vogue in the empire. 


\section{The religious system of China \\ vol. I}

after a lapse of time entirely different from that prescribed in the $L i k i$, even considerably exceeding it in length; e. $g$. it relates that,

« in the tenth year of Ruler Suen's reign (B. C. 598), in the fifth month, Hia Ch'ing-shu of Ch'en killed his ruler P'ing-kwoh (the feudal prince Ling)... and in the twelfth year, in spring, they buried this prince.

Which makes a postponement of the burial for at least twenty months. Similar uncertainty prevails with regard to the emperors of the Han dynasty. The Old Ritual of the House of Han (241) records indeed that the founder of the dynasty was dressed on the third and encoffined on the seventh day after his death, so that the rules laid down in the $L i k i$ were observed in his case. It is also probable that ice was used for him, as among the Records of the ritual of the said house we find that "basins were filled with ice in obedience to the established rites" (242). But as to the burials of that family of sovereigns, there never was any question of a fixed time for them, the dates, as they are given in the official books of history of that epoch, varying between the month in which the death took place, and the ${ }_{\text {p.267 }}$ three following months. In those ages, however, the opinion strongly prevailed that it was improper and indicative of a great lack of devotion to the deceased to confide their bodies hastily to the earth. This is sufficiently evinced by the Shih ming, a small vocabulary professedly composed during the Han dynasty, which has :

«When the burial takes place ere the usual number of days and months have elapsed, it is spoken of as a rash burial, which expression means that people for want of devotion are anxious to perform the interment without delay. But if the corpse is not interred when the said periods have elapsed, one calls it a retarded burial, that is to say a burial which proves that people, slow and indolent, do not care to set the soul at rest at an early date. (243)

Succeeding dynasties have never revived the old rescript that the Son of Heaven should be buried in the seventh month, including that in which he has breathed his last. The Dynastic Histories teach us that, previous to the reign of the family of Thang, such burials used to take place in the month following the decease, and that, during this dynasty, the period of postponement varied 


\section{The religious system of China}

vol. I

between the fourth and the twelfth month. This information gives us a right to conclude, that in the case of official persons and the common people the time of burial was not bound by strict customary rules. We can easily understand why this should be the case. The I li prescribes that a lucky period must be selected for a burial, and this precept having been faithfully conformed to by the whole succession of dynasties, including that which is now seated on the throne, it has pushed the ancient rule into the back ground, as being inconsistent therewith. Consequently, as a matter of course neither the Khai yuen Rituals, nor the Thung li of the present dynasty prescribe any fixed period for the burial of any one.

In the first part of this Book it has been shown that people now-a-days no longer delay the dressing and coffining of their dead for a fixed period of time. But as to the interment, we have seen that they often defer it, though for reasons entirely different from those which regulated the conduct of their preChristian ancestors on the point, to wit, because they wish to obtain graves which in all respects p.268 fall in with the demands of the fung shui doctrines (pp. 102, 105, 132). Yet traces of the original motive for such delays are still discernible. We have seen that calling back the soul was anciently considered a proof of filial devotion. Consequently, delaying the burial, which likewise had for its object to further the revival of the dead, must also have been from the very beginning a proof of filial devotion; and now we see indeed that a hiong tsòng or 'hasty burial' (see p. 102), such as is performed on the first or second day, is generally decried as evidence of the lack of filial love. Though the bulk of the people are in the habit of burying their dead so soon as that, yet such interments are considered quite unworthy of a family of distinction and are only excusable in the very poor, who know no better. At Amoy, everybody understands the term hiong tsòng, as meaning a burial portending evil or which will never bring good luck to the offspring ; on the other hand, a burial after the dead has been stored away for a pretty long time is there called a kiet tsòng, or burial which will prove prolific of blessings to the descendants, because the soul will gratefully reward them for it. Anyhow, fashionable people in southern Fuhkien deem it a sin against filial devotion to bury a father or mother ere seven days have elapsed, especially so, if the deceased has reached a considerable age. 


\section{The religious system of China}

vol. I

The prevalence of similar ideas in Fuhchow was noticed by Mr. Doolittle.

«The very poor - he writes - are often obliged, in order to save expense, or for other reasons, to bury their dead in the course of a few days after death. It is considered disreputable and a mark of the very lowest poverty, or that the dead is destitute of friends and relatives who take an interest in the honour of the family. If the body is buried in the course of a few days after death, it is called 'blood-burial', or a burial of blood. The corpse is believed to have blood in it or the blood has not yet dried up ${ }^{1}$. 'Blood burial' is used as a term of reproach, and refers to hasty burials, preceded by few mourning solemnities. (244)

In chapter I of the next volume we shall have to review the practice of keeping encoffined corpses at home in yet another light.

1 This must be understood, of course, as meaning that lire is not yet extinct. As we had occasion to show on page 217, the blood of a living being is identified by the Chinese with his vital energy; and this is very natural, as a body dies when it is deprived of blood. 


\section{CHAPTER III}

\section{On placing precious objects in the mouth of the dead}

p.269 The idea that death is merely a long protracted sleep and that corpses may come to life again, has, besides recalling the soul, howling and postponing of burials, given rise in China to some other practices which it becomes our duty to pass in review. In the first place, it has prompted the people since times immemorial to stuff the mouth of the dead with things that are supposed to be imbued with vital energy derived from the great element Yang, and therefore deemed able to facilitate revival and at the same time to retard decomposition, so that the soul, on returning, might at any time find its flesh and blood in a state fit for re-occupation.

Among these articles, a certain class of minerals called yuh, embracing probably sundry sorts of jade or jasper, nephrite and agate, have always obtained a first place. The Cheu li informs us that,

« at funerals of the highest order, the Manager of the Signets of Jade provided (bruised) jade, to be mixed up with the rite for the mouth, as also (pieces of) jade to be put into the mouth. (245)

A similar duty at those times was incumbent upon a certain official styled Manager of the Stores for Jade (246). The Li ki contains many references to the custom with which the above passage acquaints us, which proves that it held a very important place among the funeral rites at that time. This is still more evident from the fact that princes and sovereigns were in the habit of sending to one another, by special messengers, the jade required for stuffing the mouth. We read indeed in ch. 14 of the Li ki (I. 19) that

« at the mourning rites for Khao, the ruler of the state of Chu-leu, the ruler of Sü despatched Yung-ki to offer condolence and to present articles for the mouth of the deceased. "My Ruler, said this man, has sent me, Yung-ki, to cower down and offer articles p.270 for the mouth 


\section{The religious system of China}

vol. I

of the dead. He also sends the jade pertaining to a feudal lord and has ordered me, Yung-ki, to present it as an article to be placed in the mouth of the deceased". (247)

Of the way in which such jade for the mouth was presented by such a messenger, ch. 54 of the Li ki (I. 29) gives the following description.

« The man with the articles for the mouth, holding a flat piece of jade in his hands, delivers his message, saying: "My Ruler has sent me, So-and-so, to offer the articles to be placed in the mouth of the deceased". The person in attendance then enters the gate to report the message and, going out of the gate again, he says: "The orphan son So-and-so is waiting for you". Upon this, the bearer of the things for the mouth enters the gate, ascends the steps of the hall and delivers his message, after which the son bows to him, with his forehead to the ground. Now the other squats down, depositing the jade on the south-east of the place where the coffin is stored away and where a Phragmites mat is spread for the purpose; but if the burial has already taken place, he lays it down on a Calamus mat. This done, he descends the steps and returns to his place. The majordomo, in his court robes, but with mourning shoes on, now ascends the western steps, turns his face to the west, squats down, takes up the jade, descends by the western steps and goes to the east (of the court-yard). (248)

We see from this passage that jade for the mouth was still offered even though the messenger came too late for the family to make use of it, which is a proof of the great importance attached to the custom in question.

It is by no means difficult to trace the reasons why jade stone, the most precious mineral the ancient Chinese were acquainted with, was preferred by them above all things for stuffing the mouth of their dead. Already in those ancient times it was identified by philosophy with the heavens, whereas the Yih king (ch. 17) p.271 says : "Heaven is jade, is gold". Now, the empyrean region being, as the reader will remember from page 22 , the depository of all life in Nature, of the vital energy which Nature deals out over the world, its symbols must likewise be bearers of these good things. Moreover, the 


\section{The religious system of China \\ vol. I}

celestial sphere is unchangeable, indestructible, beyond the influences of decay, and the same qualities attach to its symbols. Hence jade and gold naturally endow with vitality all persons who swallow them, in other words, they intensify their souls or shen, which are, like the heavens, composed of Yang matter (see p. 110); and they hold at a distance from the dead corruption and decay, thus furthering their return to life.

That such ideas were prevalent in ancient China may be inferred from time-honoured works and from opinions expressed by native authors on the point. In the Cheu li we read that,

« when the Sovereign fasts, the jade which he swallows is procured by the Manager of the Jade Stores. (249)

The reasons for his swallowing this mineral can have been no other than to intensify the energy of his Yang soul, in order to enable him to bring about an intercourse between this soul and such disembodied shen of others as passed for beings of a higher order, such an intercourse being indeed the object of fasting in times of old. Commenting upon the passage just quoted, Ching Khang-ch'ing says that

« jade was eaten to subdue the influence of watery vapours, whereas this mineral is the purest part of the essence of the Yang element.

But Wang Chao Yü, a scholar of the Sung dynasty, writes :

« When the energy of the soul has reached its highest stage, then it is able to have intercourse with the spirits composed of Yang matter (shen); and jade being the purest part of the essence of the Yang, it may, when swallowed, assist the soul to gain that end.

The conception that jade reinforces the vital spirits naturally entailed the belief that, when swallowed, it prevents the body p.272 from deteriorating and thus enables men to live to a great age. The most ancient native work on medicinal botany, known as the 'Botanical Canon of Shen-nung', - probably extant already in the pre-Christian era, but since the revival of literature during the Han dynasty known exclusively by quotations in later works of the same kind - declared that 


\section{The religious system of China}

vol. I

«the spiritual and immortal beings, when they were on the point of departing with this life, swallowed five pounds of solution of jade, with this effect that for three succeeding years their colour did not undergo any alteration. (250)

The prevalence of similar conceptions in the second century before our era is manifest from the following passage in the Books of the Earlier Han Dynasty :

«In the $16^{\text {th }}$ year of his reign (B. C. 164) the emperor Wen acquired a drinking-cup of jade, on which was carved this inscription : 'Master of mankind, may Thy life be prolonged to the great delight of this world !' (251)

We may further quote here the testimony of the 'Description of the Ten Islands' Shih cheu ki, an account of fabulous countries which were believed to exist in several regions beyond the oceans; however spurious this work may be, it is nevertheless useful as acquainting us with ideas prevalent in the earlier part of the Christian era, when it was probably written. It says :

«In Yung-cheu, which is situated in the Eastern Ocean, rocks of jade exist, over one thousand fathoms high. From these rocks there issues a brook like sweet wine; it is called the Brook of Jade Must. If, after drinking some pints out of it, one suddenly feels intoxicated, it will prolong life.

Finally quoting Koh Hung, an alchemistic author of the fourth century, mentioned already on page 56 :

«Grease of jade, says he, is formed inside the mountains which contain jade. It is always to be found in steep and dangerous spots. The p.273 jade-juice after issuing from those mountains, coagulates into such grease after more than ten thousand years. This grease is fresh and limpid like crystal. If you find it, pulverize it and mix it with the juice of herbs that have no pith, it immediately liquefies; drink one pint of it then, and you will live a thousand years... He who swallows gold will exist as long as gold; he who swallows jade will exist as long as jade. Those who swallow the real essence of the dark sphere (heavens) will enjoy an everlasting existence ; the real essence 


\section{The religious system of China \\ vol. I}

of the dark sphere is another name for jade... Bits of jade, when swallowed or taken with water, can in both these cases render man immortal... (252)

It is certainly superfluous to prove by more extracts from native works that the ancient Chinese were fully imbued with the belief that jade and gold could prolong life by strengthening the vital energy and thus protecting the body against decay. Both minerals have indeed for a long series of ages held a prominent place in alchemy, or the great art of preparing the elixir of life and the philosopher's stone. In our Book on Taoism we shall have to speak at length upon this art and then we must revert to the two minerals again. It now becomes incumbent upon us to show, that the notions illustrated by the above extracts in reality lie at the bottom of the custom of placing jade and gold in the mouth of the dead. We will acquit ourselves of this duty by giving a few extracts from the works of native authors who have expressed themselves explicitly on the subject.

Koh Hung says :

« If there be gold and jade in its nine openings, the result is that the corpse does not putrefy. (253)

Thao p.274 Hung-king, who lived in the fifth century, wrote :

«When a grave of ancient date is dug up and the corpse is found to look as if it were alive, then there is everywhere both upon and inside it a great quantity of gold and jade. It was an established rule with the house of Han to bury every prince or feudal lord with clothes adorned with pearls and with boxes of jade, in order to prevent putrefaction. (254)

In the latter part of the fifth century there lived a certain statesman Li Yü, of whom the following is related in the Books of the Wei dynasty (255) and in the History of the North of the Empire (256). He applied himself ardently to the ancient methods of eating jade. Once upon a certain day, with his own hands he dug out of a field over a hundred pieces of jade and powdered them, giving part of them away to others and swallowing the rest himself in the course of a year. Thereupon he died in consequence of debauchery. His body 


\section{The religious system of China \\ vol. I}

was not coffined until the fourth day, and although it was in the seventh month, the hottest of the year, his colour did not change in the least. His wife asking him to open his mouth, that she might place two pearls of jade in it, he at once obeyed her, and no smell at all issued from his throat. - Finally quoting the author of the Pen-ts'ao kang muh :

«Jade, says he, cannot positively prevent the living from dying, but it can prevent the dead from decaying away.

We do not find one word in the native literature prior to the Christian era about the use of gold for filling the mouth of the dead. But the part this metal has played in philosophy and alchemy according to the numerous extracts quoted, leaves scarcely any room for doubt that it was widely made use of for the said purpose in subsequent ages. One question still requires elucidation, to wit, why jade and gold were, in China, so especially identified with heaven. No satisfactory answer to this is supplied by any of the ancient books; so we can only guess at the reasons. Semi-civilized, p.275 simple-minded man naturally cherishes puerile ideas about the Cosmos, the constitution of which he does not at all understand. So it is not surprising to find the ancient Chinese identifying the source of precious rains, warmth and light with the most precious things they possessed on earth and, in a reverse sense, simply regarding such things as emanations from the supremum bonum. The beautiful azure colour by which many sorts of jade are distinguished from other minerals, may likewise have had some share in establishing this identification.

If the above hypothesis be correct, it is as natural as natural can be that the ancient Chinese used also other precious articles for preserving their dead. To this end they availed themselves in the first place of cowry shells obtained from rivers, lakes and seas, which were so valuable in ancient times that they were generally used for currency. This fact, well known to Sinologists, is especially manifest from the circumstance that the character [], which is the ancient hieroglyph denoting a cowry, enters into the composition of most characters which signify things of value and arts connected with trade and barter. As instances may be given : precious, objects of value ; wealth, property ; strings of currency ; tribute ; goods, merchandise ; to trade or 


\section{The religious system of China}

vol. I

barter; to buy ; to sell ; to trade, also the price of a thing ; to ransom ; dear ; cheap ; to lend ; to borrow ; to bestow presents ; etc. etc.

« The mouth of the Son of Heaven, says ch. 56 of the Li ki (I. 14), is stuffed with nine cowries, that of a feudal lord with seven, that of a Great officer with five, and that of an ordinary official with three. (257)

The way in which they were introduced into the mouth in the case of an ordinary official, is described by the $I l i$ in the following words :

« Three cowry-shells, in a basket, are set out under the western wall. (The washing of the corpse finished), the principal mourner leaves the door and, turning his face to the south, bares his left arm and shoulder, inserting his clothes between his girdle on p.276 the frontside of his body, on the right. He then cleanses his hands over a basin, washes the cowries, and holding (the basket which contains) them in his hands, he enters the back chamber. The steward washes a spoon, places it in the uncooked rice (likewise destined for the mouth), and with (the dish containing) this rite he follows the principal mourner.

The Invoker after the manner of the Shang dynasty, holding the cloth (which is to be spread over the face of the dead) in his hands, follows behind them. Entering the back chamber he takes his station against the wall, with his face northward, then removes the pillow from underneath the head of the corpse, spreads out the cloth over its face and removes the plug from the mouth ${ }^{1}$. Then taking the cowries out of the principal mourner's hands, he places them on the west side of the corpse.

Hereupon the principal mourner passes by the feet of the dead to the west side, and there, with his face eastward, he sits down on the couch on which the corpse is stretched. The Invoker now taking also the rice from the steward, places it on the north of the cowries. With his left hand the principal mourner takes some of this rice upon the spoon and pours it in the right cheek, repeating this three times and

\footnotetext{
${ }^{1}$ People in those times were in the habit of plugging the teeth open immediately after death by means of a kind of spoon of horn, lest the mouth should shut and render the stuffing thereof difficult.
} 


\section{The religious system of China}

vol. I

placing a cowry there. Then he does the same in the left side of the mouth, and subsequently in the middle, finally putting rice in the mouth till it is full (258). When the cowries are placed in the mouth, they are made to support the last molar tooth on the left and the right side (259). The principal mourner now puts on his dress and returns p. 277 to his place (260), while the Invoker after the manner of the Hia dynasty removes the remainder of the rice (261).

During the Han dynasty pearls also occupied a place among the objects which were introduced into the mouth of the dead. At least it is stated in the funeral ritual for the Sovereigns of this house that,

«their mouths were filled with rice, and pearls and jade stone were put therein, in accordance with the established ceremonial usages. (262)

And the Poh hu thung i, a well-known work professedly written in the first century, says :

«On stuffing the mouth of the Son of Heaven with rice, they put jade therein ; in the case of a feudal lord they introduce pearls, in that of a Great officer and so downwards, as also in that of ordinary officials, cowries are used to this end. (263)

The same reasons why gold and jade were used for stuffing the mouth of the dead hold good for the use of pearls in this connection; indeed, the latter are also very frequently alluded to in Chinese literature as depositories of Yang matter, and as such ranked amongst the bearers of vitality. Medical works declare on this ground, that they can further and facilitate the procreation of children ; moreover, as we had occasion to show on page 217, these same books say that pearls can be useful for recalling to life those who have expired or are at the point of dying. The native literature abounds with tales about pearls so full of Yang matter that they emitted rays of light ; it has much to relate of 'effulgent pearls', 'pearls shining during the night', 'pearls lighting like the moon', 'flaming or fiery pearls', etc. etc. Similar legends have always been current in the empire about jade stone, and these are all based, of course, on similar conceptions. The 'Record of Forgotten 


\section{The religious system of China \\ vol. I}

Matters', a little book mentioned on page 56, says that at the time of the Emperor Shen-nung p.278 (28 ${ }^{\text {th }}$ cent. B. C.),

«there existed jade which was obtained from agate rocks under the name of 'Light, shining at night'. If cast into the water in the dark, it floated on the surface, without its light being extinguished. (264)

And the Tu yang tsah pien, a work written in the ninth century by Su Ngoh, relates :

«During the reign of the emperor Wu-tsung, in the first year of the period Hwui ch'ang (A. D. 841), the country of Fu-yü brought as tribute three measures of fire-jade. This jade, which was red, consisted of pieces half an inch in length, pointed at one end and round at the other; their light shone to a distance of several tens of paces. By piling them up they could be made to do service in boiling the pot. $(\underline{265})$

Such legends about lighting pearls and jade being current in the native literature in considerable numbers, it is easy to understand why people of the present time, as we had occasion to remark on page 92, give as one of the reasons for their placing precious stones in the mouth of the dead, a desire to procure light to the soul, that it may be safely conducted along its paths in the dark Tartarus. But they have not forgotten that the principal object of this practice is, to save the body from a speedy decay.

It finally remains to be noted, that the principal codes of rites all prescribe the placing of the precious articles, which have been dealt with in this chapter, in the mouth of the dead, so that we seem warranted in saying that these things have in all ages played their part in the disposal of the dead. Silver has obtained a place amongst them, as also coins, probably because these have replaced the ancient cowries as currency. In the Khai yuen Codex it is ordained that grandees and officials of the first, second and third rank

« shall receive in their mouth circular pieces of jade, those of the fourth and fifth rank blue jade, those of the sixth and lower ranks cowries. 


\section{The religious system of China}

vol. I

Chu Hi's Rituals for Family Life prescribe one coin in the left side of the mouth, one in the right side and ${ }_{\text {p. } 279}$ one in the middle, while ${ }^{1}$ the Ta $T^{\prime}$ 'ing thung li says :

«In the case of an official of the first, second or third degree, five small pearls and pieces of jade shall be used for stuffing the mouth ; in that of one of the fourth, fifth, sixth or seventh rank, five small pieces of gold and of jade. The gentry shall use three bits of broken gold or silver ; among ordinary people the mouth shall be stuffed with three pieces of silver. (266)

It may be finally noted that, in the province of Fuhkien, people in easy circumstances nearly always put an armlet of jade on one wrist or on each wrist of the dead 2 .

1 Correction: for while read The Imperial rescripts issued in 1372 for the burial of commoners, ordained that the latter might place no more than three coins in the mouth of the dead; but another edict, issued in the same year, entitled the officers of the five highest degrees to receive pearls in their mouths, and those of the lower ranks small pearls; see the History of the Ming Dynasty, ch. 60, II. 22 and 15.

2 The customs dealt with in this chapter we beg especially to recommend to the attention of Ethnologists, as they may be of service in placing in another light analogical practices widely prevalent in other parts or the globe, and hitherto mostly explained as serving to provide the dead with the means of defraying certain expenses beyond the grave. It is well known that the placing of articles of value in the mouth of the dead obtained among the Greeks, the Romans, the Hindus and the ancient Mexican emperors. In the island of Bali, where cremation exists, it is customary for the priests to put a gold ring inlaid with a precious ruby on the tongue of a body which is to be burnt ; this ring is, however, replaced by a flower before the funeral pile is kindled (Van Eck, Het Tijdschrift van Nederlandsch Indië, VIII, p. 114). Collin de Plancy writes in his Dictionnaire Infernal (art. Mort) : «Dans le royaume de Tonquin, il est d'usage, parmi les personnes riches, de remplir la bouche du mort de pièces d'or et d'argent, pour ses besoins dans l'autre monde. » This explanation is perhaps as incorrect as the suggestion that the cake of flour, honey etc., with which the ancient Romans provided the mouth of the corpse, was designed to conciliate the fury of Cerberus and thus to procure a safe and quiet entrance into the infernal regions. It is more likely to have represented a continued feeding or the dead, a practice which, as we shall show in Ch. VII, also prevailed on an extensive scale in both ancient and modern China. 


\section{The religious system of China \\ vol. I}

\section{CHAPTER IV}

\section{On coffins and grave vaults}

p.280 The ideas of the resurrection of the body, so clearly illustrated by the customs dealt with in the three last chapters, have naturally prevented the Chinese from ever adopting any system of disposition of the dead which entails a quick destruction of the body, such as cremation, water burial, exposition in the open air, etc. From the earliest times we find them clinging to the system of burning their dead in the ground, in coffins of great solidity, sometimes in several coffins enclosed one within another, in receptacles calculated to ward off putrefaction for a long time. Coffins are, moreover, made of certain sorts of wood which, as philosophy teaches, are pervaded with Yang matter and thus in a condition to further a speedy revival of the body. So, the Chinese are strict adherents to the doctrines of Democritus, who preached against the burning of the dead, saying they must be buried in expectation of a resurrection which he predicted for every one (267).

There is no evidence that the art of embalming the dead, carried to such perfection by the ancient Egyptians, was ever known to the Chinese. Neither in their literature, nor in actual life do we find any trace of it. So far as we know, there is only one instance on record of a faint attempt at preserving a body from decay in an artificial way ; it occurs in ch. 242 of the History of the Sung Dynasty $(1,12)$. Li Ch'en, a concubine of the emperor Chen Tsung, had born him a son, who in A. D. 1023 ascended the throne under the name of Jen Tsung ; When Li Ch'en breathed her last, the emperor, her son, was still totally ignorant of the fact that she was his mother; some high dignitaries, acquainted with this circumstance, but not at liberty to reveal it, nevertheless p.281 dressed her carefully in the attire of an empress and had mercury put into her coffin. After a time being apprized of the truth, Jen Tsung had the corpse transferred to a new coffin, and on this occasion it was found that 


\section{The religious system of China \\ vol. I}

« she looked like jade stone and as if she were alive; her attire was that of an Empress-Dowager, and corruption had not done its work, the mercury having preserved her body.

Thus embalming having never played a part of any importance amongst them, the Chinese were naturally thrown back upon the coffins as a means of preventing the decomposition of the dead. The ways in which they have concentrated their attention and sharpened their inventive genius upon coffins, form an interesting page in the book of their religion of the body and the soul, a page which we must not neglect to lay open before our readers.

\section{Coffins in ancient times.}

All the Chinese records, either authentic or apocryphal, show that, from the highest antiquity, burial in the ground has been the usual method of disposing of the dead in the Kingdom of the Midst, and that coffins have always been inseparably connected therewith. Only one classic, the Yih king, pronounces another opinion.

« In times of antiquity, it says (ch. 15), those who buried their dead covered them thickly with firewood and committed them to the earth in the open field ; they did not raise a tumulus over the grave, neither did they plant trees on the spot. The length of the period of mourning was not regulated by numbers. The holy men of subsequent ages modified this state of things by introducing coffins and vaults.

Though frequently quoted as authoritative by writers who stood forward as the advocates of simplicity in the disposal of the dead, this statement stands alone in Chinese literature, which therefore gives us sufficient grounds for believing that it rests on no historical basic. It looks rather like a product of p.282 fancy or the private opinion of some individual who simply imagined matters must have been so in the dark night of times of which we know nothing, in the year one. Even supposing the extract refers to ages on which the most ancient Chinese records throw a glimpse of historical light, still it is in flagrant contradiction with an ancient tradition preserved in the Li ki (ch. 9, I. 23 seq.), which runs as follows : 


\section{The religious system of China \\ vol. I}

«In the time of Yiu-yü ( $i$. e. the Emperor Shun, who is said to have lived in the $23^{\text {rd }}$ century B. C.) they used coffins of earthenware; under the sovereigns of Hia $\left(22^{\text {nd }}-18^{\text {th }}\right.$ cent. B. C. $)$ they built brick enclosures over the same. The people of the Yin dynasty $\left(18^{\text {th }}-12^{\text {th }}\right.$ cent. B. C.) used coffins and grave vaults of wood, and those of the House of Cheu $\left(12^{\text {th }}-3^{\text {rd }}\right.$ cent. B. C. $)$ put in the grave the side curtains of the catafalque, and the shah ${ }^{1}$. The people during the Cheu dynasty buried those who died between sixteen and nineteen in the wooden coffins and vaults of the people of Yin ; those who died between twelve and sixteen and between eight and twelve they interred under the brick enclosures of the sovereigns of $\mathrm{Hia}$, and those who died in infancy, for whom no mourning is worn, in the earthenware coffins of Yiu-yü's time.

In the first chapter of the next volume, in attempting to trace the most ancient forms of burial in China, we shall have again to refer to the above traditions, and to show that the statement about the use of coffins and vaults of burnt clay before wooden coffins came into vogue, deserves more credit than would superficially appear. It is interesting to note that during the Cheu dynasty the improved method of burial was only for the benefit of up-grown people, and that the less effective and older methods, upheld by that tenacity of existence which characterizes so many funeral customs in different parts of the globe, continued to be practised for the young, whose dead bodies were the objects of little interest. In the next volume it will be shown, that even at the present day earthenware pots for burying very young children are still widely made use of, and vaults of masonry are constructed over the coffin in graves of the wealthy.

p.283 Chinese literature contains also hazy references which point to the use, during the Cheu dynasty, of coffins of solid stone, by which term may be understood marble, dolomite or granite. The Shi ki relates :

Fei-lien begot Wu-lai. Wu-lai was a man endowed with athletic strength, and Fei-lien was a good racer. Both father and son served

\footnotetext{
${ }^{1}$ See page 185 sqq.
} 


\section{The religious system of China}

vol. I

Cheu of the Yin dynasty by their talents and strength. When king Wu of the House of Cheu had slain Cheu ${ }^{1}$, killing at the same time Wu-lai, Fei-lien made a coffin of solid stone for Cheu and buried him in the north of the capital. Finding on his return that nobody did anything for Cheu to requite the favours conferred by him, he erected an altar on mount Hwoh-thai (near Cheu's grave), to perform there himself what others had neglected to do, and he found on the spot a stone coffin bearing this inscription: "The Emperor of Heaven has decided that Ch'u-fu (this was Fei-lien's title) shall not be implicated for having played a part in the disorder created by the house of Yin ; he presents him with a coffin of stone, to shed glory on his kindred". After his death he too was buried on mount Hwoh-thai. (268)

However legendary this episode may be, it is not without interest, as showing that the father of Chinese historiography who recorded it, as well as the unknown author from whom he probably borrowed his information, were partisans of the doctrine that burying a human being, even though he were, like Cheu, a prince reproached for being the greatest monster of wanton cruelty that ever lived, constitutes an act of charity worthy to be rewarded by the highest divinity in existence. It further shows that in those ancient times it was considered a great privilege to be interred in a coffin of solid stone, and that it was a mark of honour for a family to have one of its members committed to the earth in such a receptacle. p.284 At all events we may conclude from this that they were used only in very exceptional cases.

They who agree in opinion with those who believe that fables always contain a grain of historical truth, may find in the domain of Chinese mythology a hint that stone coffins were still used at the beginning of our era, or, at least, that they were at that time not yet effaced from the memory of the people. The Books of the Later Han Dynasty relate the following about a certain Wang Khiao, a governor of the country of Yeh during the reign of the Emperor Hiao-ming (A. D. 58-76) :

\footnotetext{
1 In the battle of the country of Muh, 1122 B.C., king Wu, the renowned founder of the Cheu dynasty, completely overthrew king Cheu, the last tyrant of the house of Yin, thus accomplishing his conquest of the empire. Compare the foot-note on page 116.
} 


\section{The religious system of China}

vol. I

«Afterwards Heaven sent down a coffin of jade stone at the front floor of his hall. His underlings tried to take it away, but they could not move it, upon which Khiao said: "Can this mean that the Emperor of Heaven calls me towards him ?" He bathed himself, put on his official attire with its ornaments, and lay down in the coffin, the lid being immediately closed over him. When the night had passed, they buried him on the east side of the city, and the earth heaped itself up over him in the shape of a tumulus. All the cows in the district on that evening were wet with perspiration and got out of breath, and nobody knew whence this came. The people thereupon erected a temple for him. (269)

The Records of Khing-cheu which were written in the fifth century, relate that, « at Lin-siang there is in the water a couch of stone upon which stand two coffins of solid stone, green like copper mirrors. There is nobody who can give any information about them. (270)

Lin-siang was situated in the north eastern part of the present province of Hunan.

We must now direct our attention to the coffins of wood, which, according to the Li ki (see p. 282), came into vogue during the Yin dynasty and have continued to be generally used down to p.285 the present day. The word by which they are denoted throughout the native literature, reads kwan ; and as the written form of this word [ab] is composed of [a], 'wood' and kwan [b], 'official', there is ground for supposing that wooden coffins were at the outset used for the ruling classes only ; but we have nowhere any direct evidence for this in the books.

«For a Son of Heaven, says ch. 11 of the Li ki (I. 46), the coffin is fourfold. One of buffalo and rhinoceros leather covers the body ; it is three inches thick. Then comes a coffin of the I tree, then two of Rottlera wood. The four are all complete inclosures. Of the coffin bands two pass lengthwise around the coffin, and three crosswise. For each band there is one jen. (271)

And ch. 58 (I. 34) adds : 


\section{The religious system of China \\ vol. I}

«The highest coffin of a feudal ruler is eight inches thick, the next six inches, and the innermost four. The large coffin for a Great officer of the highest rank is eight inches thick, and the next six inches; for a Great officer of lower rank the dimensions are six and four inches, while for an ordinary officer the coffin is six inches. (272)

So, an emperor was buried in four coffins, a feudal lord in three, a Great officer in a double one, and an ordinary servant of the state in a single coffin, number thus regularly decreasing with the rank of the dead. No doubt this rule was founded on the idea that the body of a pre-eminent person ought to be better preserved for the resurrection than that of a less important individual, an idea which, as we have seen in chapter II, also prompted the ancient Chinese to defer the dressing, coffining and burial of eminent personages longer than in the case of less distinguished people.

The jen, mentioned in the above extract, were evidently instruments for closing the coffins, as we are explicitly told they stood in immediate connection with the ropes wound around the same. Neither the Li ki, nor any of the ancient books describe them; so we are compelled to apply to the commentators of the p.286 $\mathrm{Li} \mathrm{ki}$ for information on this point. Taking into consideration that the character [], by which the said Classic denotes them, occurs in the ancient books generally in the sense of flap or lapel of a coat, or in that of the seam where a coat opens and fastens, those commentators do not hesitate to assert that the jen were a kind of pegs used to clamp the case and lid together. Ching Khang-ch'ing says, "the jen are the 'small waists' which were in vogue in his time" (273), instruments "broad at both ends and thin in the middle" (274); very likely they were on account of this shape denoted by the name of waistlets. Three centuries after Ching, Khung Yingtah wrote :

«In ancient times coffins were not nailed; hence leather straps were used to join the different parts together. The straps laid lengthwise were wound around them twice, and those laid crosswise three times, and to each strap there was one jen. The coffins were not nailed, but people chiselled them out at the sides, thereupon they made excavations at both ends over the seam where the two parts joined, 


\section{The religious system of China \\ vol. I}

and secured these parts together by means of waistlets, which made them fit tightly. (275)

Finally to give the opinion of Chen Hao, an author already quoted on page 188 :

« The place, says he, where the seam of a coat closes, was called jen. Therefore the waistlets used to secure a coffin and lid together, were likewise denoted by this name. (276)

Although these extracts are not particularly clear in all respects, yet they sufficiently show that the jen were very nearly the same kind of thing as the double dove-tailed pegs of wood, which the modern Chinese still use to close their coffins. These pegs have been spoken of on page 95, and the way in which they are fastened may be learned from page 321. At any rate it is certain that the use of these instruments dates back as far as the time of Ching Khang-ch'ing, that is to say, the beginning of our era. Khung Ying-tah's p.287 assertion that no nails were used for coffins in ancient times - an assertion which is confirmed by the fact that nails are nowhere mentioned in this connection in the old writings - is of peculiar interest because it explains why, as has been said on page 95 , coffin nails are still so sparingly used in modern times, even for the huge coffins of the rich only two being allowed for the lid. The same strong spirit of conservatism which bears sway all the world over where sacred customs are concerned, will account for this.

It is curious to see that even in such an advanced stage of civilization as that represented by the age of Cheu, when iron was generally used, the custom still obtained of joining the different parts of coffins together by ropes or straps and wooden pegs, instead of using nails for the purpose. We do not hesitate to conclude that we are here face to face with a survival of centuries still more remote, in which iron was unknown. It is a fact well established by archæological science that, in spite of the general introduction of iron, traces of previous ages of lower culture hardly ever disappear; such traces have even been discovered in that part of the world inhabited by ourselves. Other survivals of this kind are revealed to us by ch. 58 of the Li ki (I. 35). There we read : 


\section{The religious system of China \\ vol. I}

« For a Ruler the coffin is lined with red stuff, fastened with nails of sundry metals; for a Great officer it is lined with dark coloured material fastened with nails of ox-bone ; for an ordinary officer it is not nailed. (277)

We feel strongly inclined to believe that those nails of bone and of various metals - probably copper and bronze - were instruments which, as late as the age of Cheu, had survived the general introduction of iron.

The custom of varnishing the receptacles of the dead, which, as stated on page 106 , is generally prevalent now-a-days, is proved by the Li ki to be of very old standing.

«In case of the Ruler of a state, says this book in its $58^{\text {th }}$ chapter (I. 36), the lid is varnished and has three jen with three straps. For a Great officer it is likewise varnished and has two jen with a like number of straps. In the case of a common officer the lid is not varnished but it has likewise two jen with two straps. (278)

p.288 Considering that the object of coffins was to protect their contents from decaying influences, it is not improbable that such varnishing also included a previous caulking ; but for this there exists no written evidence.

To prevent decomposition of the corpse being the main object of the coffins of antiquity, it is perfectly natural they should be made of very thick, substantial wood. Ciphers on this head are given by the $L i k i$ in the passage quoted on page 285. But these are controverted by Mencius, who, according to the classical writings which bear his name, said on a certain occasion :

«Anciently coffins and funeral vaults were not of fixed dimensions. But in middle antiquity the coffins were seven inches thick, and the vaults also, from the emperor down to the common people. (279)

It should, however, be taken into consideration that Mencius is chief amongst all the oracles of ancient China for making sweeping statements about matters of which he had little or no knowledge, thus rendering his evidence untrustworthy. 


\section{The religious system of China \\ vol. I}

Grave Vaults.

We have now to devote our attention to the grave vaults, which have been referred to in some of the extracts quoted in the foregoing pages. In the books of both the pre-Christian and the post-Christian era they are so often mentioned in the same breath with the coffins, that there can scarcely be any doubt the people regarded both with the same amount of interest ; and this induces us to conclude that they served, like the coffins, to preserve the corpse from speedy decay.

In all books, ancient as well as modern, they are represented by the character [], now pronounced kwoh ; by way of abbreviation this is often written $[a b]$. The fact that the prefix [a], 'wood', enters into the composition of the character already in such early times, gives us a right to suppose that wood was the common material out of which grave vaults were constructed from the first. Nevertheless there are instances on record of vaults having been built of solid stone during the Cheu dynasty; these instances are, however, so scanty, that we cannot but conclude that such vaults were only constructed in exceptional cases. Chapter 11 of the Li ki (I. 4) relates p.289 Tszĕ-yiu, a disciple of Confucius, said on a certain occasion :

« Formerly, our Master, while staying in Sung, saw that Hwan, the Minister of War there, was having a funeral vault of solid stone made for himself, which was not finished in three years. (280)

In the works of Chwang-tszĕ (281) we are told that, whilst digging a grave for Ling', the feudal ruler of the state of Wei, they struck upon a grave vault of solid stone, which bore an inscription ordering them to use it to bury the prince in. Though this tale bears the character of a fable or an allegory, it may serve to prove that stone funeral vaults were not unknown in Chwangtszĕ's time.

Other slight testimony for this conclusion we have in the Si-king tsah $k i^{1}$, or Miscellanies about the Western Metropolis, a little book of doubtful authority, which is said to have been composed in the sixth century by Wu

\footnotetext{
1 That metropolis was Ch'ang-ngan, in the present Shensi province, the seat of the Imperial court during the Early Han dynasty.
} 


\section{The religious system of China \\ vol. I}

Kiun. Relating how, during the Han dynasty, a certain Khü-tsih, king of Kwang-ch'wen, had several ancient tombs broken up, it says :

«In the tomb of king Siang of the state of Wei (334-319 B. C.) the vault was entirely constructed of veined stone and over eight feet high. There was room enough in it to hold forty people. To the hand it felt smooth and chilly, as if it were new. Inside it there was a couch of stone and a screen of the same material, elegantly finished on all sides, but there was no trace of a coffin, nor of implements for the use of the soul.

Of a character more doubtful still are a couple of passages referring to grave vaults of copper. The Yueh tsueh shu or Book on the Extinction of the Kingdom of Yueh, which was p.290 written probably during the latter part of the Han dynasty, records of Hoh Lu, a monarch who in the period between 514 and 496 B. C. bore sway over the kingdom of $\mathrm{Wu}$, that "his copper grave vault was composed of three layer". And ch. 6 of the Shi ki (I. 29) relates that Shi Hwang, the renowned monarch of the house of Ts'in who united the whole empire under his sceptre in the third century before our era, had a grave vault of copper made for himself. Seeing that these passages stand quite by themselves in literature, we consider them as not worthy of much credit. Perhaps we ought to read, instead of [a], 'copper', [b], 'wood of the Thung tree', this, as we shall see further on in this chapter, having always been a select kind of timber for the making of coffins.

As to the construction of wooden vaults, this may be easily understood from particulars given in the ancient books. The $I$ li prescribes that,

« when the (wood for the) grave vault has been piled up in the shape of the character 井, the principal mourner shall turn his face to the west and make bows to the workmen; then he shall walk around the vault, keeping it on his left hand side, and so he shall return to his place and wail, but without stamping his feet. The women shall in the meanwhile wail in the hall. (282)

This piling up of the wood, which had for its object to enable the mourners to convince themselves that the material for the vault was in perfect order, took place prior to the burial, on the premises of the house of mourning. The way 


\section{The religious system of China \\ vol. I}

in which, at this inspection, the pieces were arranged, suggests the idea that the vault was constructed of beams piled up inside the pit, on the four sides. Already before the burial they were put in their places, and when the coffin had been lowered, and the food, implements etc. for the use of the dead had been arranged around it,

« a wooden frame was placed over everything, the obverse down. Then followed a mat to keep off dust from the coffin, the obverse up, and finally came pieces of wood to support the earth. (283)

«In the case of an emperor, says chapter 11 of the Li ki (1.47), p.291 the funeral vault is made of cypress wood, cut from the foot of the trunk in pieces six feet long. (284)

Chapter 58 (I. 47 seq.) adds :

« Rulers have a vault of pine, Great officers of cypress wood, ordinary officers of sundry sorts of wood. The space between the coffin and the vault can, in case of a Ruler, contain a music-stopper ; in that of a Great officer it can hold a water jar, in that of an ordinary officer a liquor jar. In the case of a Ruler they line the vault, in that of a Great officer they do not do so. (285)

Thus the width of the vaults cannot have been very large, a music-stopper being, according to commentators, a square tub which, at musical performances, was beaten from time to time with a clapper, as a sign to the musicians to begin or to stop.

In the age of Confucius grave vaults were by no means considered indispensable for the burial of the dead. Chapter 13 of the Li ki (I. 28) reports that the sage said on a certain occasion :

«If you wrap the body round from head to foot and quickly bury it without using a vault, this being suitable to your means, you may be said to act in obedience to the established rites. (286)

And in the Lun yü we read :

«When Yen Yuen died, (his father) Yen Lu begged for the Master's carriage to make a vault out of it; but Confucius said: "Every one 


\section{The religious system of China}

vol. I

calls his son his son, whether he has talents or not. My son Li has also died, and he has got a coffin, but no vault ; I did not walk afoot at the time to make him one. I belong to the retinue of Great officers, and therefore I may not go on foot. (287)

The particulars contained in the above pages teach us that the ancient Chinese used double, triple and quadruple coffins of different kinds of wood and hides, with vaults of wood or solid stone. p.292 Knowing from the preceding chapters how firmly they believed in the possibility of resuscitation, there is no reason for believing that the numerous and substantial enclosures for their dead served any other object than that of preserving the corpses from decay, that they might at any time be fit to harbour the soul once more.

This conclusion is confirmed by the following interesting passage in ch. 11 of the Li ki (I. 4), which reproduces a discussion between some of the disciples of Confucius.

«Tseng-tszĕ said : "I have heard from the Master that one should desire to decay away quickly after death". "The superior man, replied Yiu-tszĕ, did not say so". "I repeat that I have heard the Master say so", returned Tseng-tszĕ. "Formerly, said Tszĕ-yiu, when Confucius was staying in Sung, he saw that Hwan, the Minister of War, had been engaged three years in having a grave vault of solid stone made for himself, which was not yet finished, and he said : "Acting like this is extravagance indeed; nothing can be better after death than to decay away quickly". That one should wish to putrify soon after death was said by him with reference to Hwan, the Minister of War". - Tsen tszĕ reported this statement of Tszĕ-yiu to Yiu-tszĕ, who said : "And yet I persist in saying that those were not the words of our Master. For, in Chung-tu ${ }^{1}$ he issued an official order that coffins were to be four inches thick and grave vaults five inches, and from this I feel convinced that he did not wish the dead to decay away quickly". (288)

In the Books of the Early Han Dynasty we came across an episode in the life of the emperor Wen, (B. C. 179-156), which proves that the idea

\footnotetext{
${ }^{1}$ A town in the state of Lu, in which Confucius held for a time the dignity of Governor.
} 


\section{The religious system of China}

vol. I

underlying the use of substantial p.293 coffins and vaults was at that time much the same as in the Confucian age.

«Ordering lady Shen to strike the lute, His Majesty himself accompanied the music with a song, but upon this his mind became gloomy and dejected, and he was filled with melancholy thoughts. Looking around him, he said to his ministers : "Oh, how would it be possible to injure a vault made of solid stone from the northern mountains and caulked with hemp and silk, mixed with varnish !" All those around declared that he was right, but Shih-chi stepped to the front, saying: "Suppose in such a vault there are things worth coveting, there will always be cracks enough in it, even though it were as close as the southern mountains. But if there is nothing of the kind in it, what then is there for Your Majesty to be anxious about, even if they do not bury Her in a stone vault at all ?". (289)

Here we see an emperor, in the midst of his enjoyments at the side of a favourite concubine suddenly remembering that death would come to put an end to all his earthly pleasures, and pondering at the same time on the means to keep his body in an undecayed state, in order that a life of happiness might dawn for him hereafter.

The different sorts of Wood used for Coffins and Grave Vaults.

To further the resurrection of the dead being the most important point in the use of coffins and vaults, it is quite natural that these were anciently made of special sorts of timber of great durability, and by preference of such kinds as were believed to be imbued with vital energy, that is to say with shen, or afflatus produced by the great Yang element (comp. page 110). As different extracts reproduced in the above pages have shown, the ancient books mention as such : I, Rottlera, Pine, and Cypress. The I, identified with the white aspen is a big and lofty tree, of which an author of the eighth century says :

« It is extremely abundant in northern countries and planted p.294 there in burial places. (290) 


\section{The religious system of China}

vol. I

« The fiber of the wood, adds the Pen ts'ao kang muh, is fine and white, the wood solid and straight, and accordingly it is much used for beams and posts, which never get distorted, nor bent. (291)

According to the Khanghi Dictionary it is, moreover, proof against moisture. The Rottlera possesses qualities no less excellent. The $P^{\prime} i$ ya says of it :

«The Rottlera is the king of trees, because among all the sorts of timber there is none better than that produced by the Rottlera. (292)

«It is, adds the Pen ts'ao kang muh, on this account that, at the Imperial court, coffins are styled structures or buildings of Rottlera. (293)

Elsewhere we read :

«People make coffins of it, which are of still better quality than even those of Pine and Cypress wood. (294)

Throughout the Chinese literature, even in recent works such as the Ta Ts'ing hwui tien and the Ta Ts'ing thung li, the expression "structure or building of Rottlera" occurs as a special name for the imperial coffins, which fact shows that the wood of this tree played a prominent part in their construction.

A place no less important is occupied by the Pine and the Cypress. In mediæval and modern ages we even see them entirely supplanting all other trees. Besides their solid, resinous wood distinguishing itself by its durability, even when buried in the ground, people have no doubt been prompted to use it extensively for coffins from the fact that both trees are possessed of great vitality, so that the wood, when placed around the dead, might facilitate their return to life. Thus we have here again a puerile notion of the same kind as those reviewed in the last chapter, where we have shown that the Chinese place in the mouth and on the body of their dead all sorts of things which they believe to be imbued with vitality on account of a supposed p.295 connection with the celestial sphere, the chief representation of the Yang element.

But why have the Pine and Cypress always been considered in China as special stores of vitality? The ancient Chinese, as well as Pliny, must have 


\section{The religious system of China \\ vol. I}

observed that "Pinus et Cupressus adversus cariem tineasque firmissimae" (295). These trees being in fact more proof against the ravages of air, weather and inserts than perhaps any other growing on the soil of the empire, it is natural enough that the inhabitants thereof ascribed their strong constitution to the large amount of vital power in their wood. Neither the scorching summers, nor the Siberian winters of northern China can divest them of their foliage; proudly raising their lofty heads into the sky, these giants of the mountains stand intact, while everything around has died off in an ocean of snow and ice. Indeed, Chwang-tszĕ was right in exclaiming :

«Pines and Cypresses alone on this earth are endowed with life ; in the midst of winter as well as in summer they are ever green. (296)

Nor is their capacity to live long equalled by any other tree : we need only remind our readers of their Californian congener, the Sequoia Gigantea. Several Chinese authors dilate upon Cypresses and Pines of an astounding site and age. Liu Ngan, a philosopher of the second century before our era whom we have mentioned on page 57 , speaks, in the $16^{\text {th }}$ chapter of his Explanations of the Great Light, of Pines of one thousand years old, and Koh Hung says :

«In Pines of one thousand years old there is something resembling either a blue ox, a blue dog or a blue human being ; in all these cases the tree is a thousand years old. (297) Cypresses of one thousand years have deep roots, shaped like men in a sitting posture, seven inches in length ; when they are cut, they lose blood. And branches of Pines which are three thousand years old have underneath the bark accumulations of resin in the shape of dragons, which, if pounded and consumed in a quantity of full ten pounds, will enable a man to live five hundred years. $(\underline{298})$

p.296 The Shuh $i k i$, a work probably of the earlier part of the sixth century, says :

«In the Fragrant Island, which is a part of the Chu-yai department, there are Pines of a thousand years, the fragrant smell of which extends over a distance of ten miles. And in the district of Lu-shi (in the far west of Honan province), there is an old burial ground of the 


\section{The religious system of China}

vol. I

Lords of Lu, flanked by two Cypress trees which extend their foliage over two hundred and more paces.

Coming down to more modern times, we read in the Records of the Country of $\mathrm{Wu}$, written probably about the end of the ninth century :

«On the Banks of the great river in the south of the district of Sungyang (in Ch'ehkiang province) there is a Pine which has a circumference of eighty-one spans and, in a hollow space inside the trunk, room enough for thirty people to sit down. (299)

The Memoirs of Honan, the author of which, we believe, lived in the $14^{\text {th }}$ or the $15^{\text {th }}$ century, say :

« On mount Sung, at the Thien-fung monastery, there are three old Cypresses, which the Empress Wu of the Thang dynasty (A. D. 684705) had invested with the dignity of Great officers of the fifth rank ; their foliage covers a hundred and odd paces of ground. (300)

To make a final citation from a large quantity of extracts lying before us the Wu tsah tsü, a work of the Ming dynasty, pretends that

« on mount Sung, at the Sung-yang temple, there stands an old Cypress, so thick that no less than five p.297 persons holding each other's hands are required to embrace it. (301)

As already set forth on page $271 \mathrm{sqq.}$, the use of jade and gold to preserve dead bodies from decay was intimately connected with the place these precious minerals held in alchemy as producers of elixirs of life. A like phenomenon presents itself with regard to the Pine and Cypress, the two other possessors of vital energy which are universally used in this capacity of protectors of the dead from putrefaction.

The Han Wu-ti nei ch'wen, the book quoted on page 56 which relates the adventures of the Emperor Wu (B. C. 140-86) with a fabulous Queen of immortal beings residing in the far West of the empire, says that

«these immortals use as a first-rate drug the resin of Pines and Cypresses, because this can prolong life, when consumed. (302) 


\section{The religious system of China \\ vol. I}

Liu Hiang wrote in his Lieh sien ch'wen (see page 56) with reference to the Pine trees :

« Those who ate or drunk of them have all attained to an age of three hundred years. (303)

During the Han dynasty the ruling classes believed so firmly in the lifeendowing properties of the Cypress that,

« on New Year's day they wished a long life to the emperor with wine prepared from Cypress leaves. (304)

From an extract quoted on page 295 we see that Koh Hung, the great alchemist, declared that the resin of Pines of three thousand years old enables men to live five hundred years. In the same chapter of his work he dishes up the following tale, which, though betraying his extravagant credulity, is nevertheless useful, as shedding light upon the ideas and conceptions about the Pine, which occupied the Chinese brain in his time.

«Moreover, says he, I have heard that in Shang-tang there lived a certain Chao Khü, who was since several years so thickly covered with leprosy that he proved incurable, though every one had tried his medical abilities upon him. When he was on the point of breathing his last, some one said that the best thing to be done was to cast him into a p.298 running stream of water; but his sons and grandsons, after having repeatedly taken counsel with the family, deposited him with some provisions in a mountain-cave. There he lay for more than a month, his heart filled with bitterness at his hard fate, sighing and weeping sadly day and night, tilt a hermit passed by the cavern, looked at him and, moved by compassion, inquired what was the matter. Sensible that he had to do with an extraordinary person, Khü bowed his head to the ground, related what had happened and implored his pity, whereupon the hermit gave him a bag of drugs, informing him at the same time of the way in which he must take them. For more than a hundred days Khü swallowed these medicines, the result being that all his ulcers disappeared, his healthy and cheerful complexion returned, and his flesh and skin became smooth and glossy as jade. When the hermit passed by again and looked at 


\section{The religious system of China \\ vol. I}

him, Khü thanked him for having endowed him with new life, and requested him to give him the recipe; whereupon the hermit said : "It is juice of Pine trees. In these mountains there is still more of it. If you refine and consume it, you may prolong your life and escape death". Having returned home, Khü took juice of Pine trees for a long time. His body became light, his breath a hundred times as strong as it had ever been before, and he reached his $170^{\text {th }}$ year without his teeth dropping

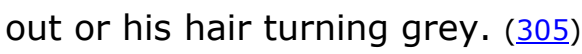

Succeeding centuries have evidently not brought about any modification in these and similar conceptions of the Chinese regarding p.299 the Pine and the Cypress, for authors of more modern date still lose themselves in vague speculations about the properties of these trees as the seats of vital power. The Description of the Sung Mountains, written during the Thang dynasty, says :

«On the high peaks of the Sung mountains there are big Pines, some a hundred, others a thousand years old. Whosoever gathers and eats their seed will live to a great age. (306)

And the Description of the Lu-shan, a work of the eleventh century treating of the picturesque mountain range west of lake Po-yang in Kiangsi province, tells us that

« the Pines on the western ranges there have the appearance of horses manes and that, if one consume such of the leaves as contain five grains, he shall enjoy a long life. (307)

In the Khuh-wei kiu wen, written in the twelfth century by the statesman Chu Pien it is related that Su Tung-p'o, a celebrated statesman and poet who lived from 1036-1101,

« while abiding in the country beyond the sea (Hainan), in the spring of 1099 took a scroll of paper and wrote: "The blessings bestowed upon mankind by the Pine are very numerous. Its flowers, its juice and the fungus which grows at its roots, if consumed, all prolong life. (308)

In conclusion let us sec what the Pen-ts'ao kang muh, the standard work on medical botany, zoology and mineralogy which has already been quoted so 


\section{The religious system of China}

vol. I

often in these pages, has to say on the subject. Far from proclaiming any new doctrines or derogating from what had already been preached by the authorities of bygone ages, it merely says :

« The juice of the Pine, when consumed for a long time, renders the body light, prevents man from growing old and lengthens his life. Its leaves preserve the p.300 interior of the body; they cause a man never to feel hunger, and increase the years of his life. And Cypress seeds, if consumed for a long period, render a man hale and healthy. They endow him with a good colour, sharpen his ears and eyes, cause him never to experience the feeling of hunger, nor to groom old ; further, they cause his body to lose its weight, and prolong his life. (․ㅜㅇ)

No other trees can, according to the same work, be converted into so many medicaments as Pines and Cypresses. Drugs which cure almost every disease imaginable, are prepared from their sprigs, leaves, seed, roots, resin and so on. All this healing power is supposed to exist simply because of the general conviction that Pines and Cypresses are stores of vitality par excellence, and that this vitality is imbibed by the sick man whose vital powers, on the wane, require reinforcement.

After all, the natural conclusion at which we arrive on a careful analysis of what native literature tells us about coffins, is that they were intended to preserve human bodies from putrefaction and to facilitate their resurrection, by enveloping them air-tight in a material which, as being possessed of vital energy, was considered capable of transmitting life once more into the clay. This fact renders it perfectly intelligible to us why, as the $L i k i$ states, the imperial grave vaults of cypress wood were constructed of timber cut out of the lowest parts of the tree in pieces of six feet long (page 291) : - indeed, the foot, as being older than any other part of the trunk, was deemed to contain more vitality than the higher and younger parts. Here then we have also it thorough explanation of a custom prevailing during the Han dynasty, and probably also in times still more ancient : that of piling up, in case of persons of rank, an extra number of pieces of cypress wood round the coffin in the grave. This evidently served no other purpose than to increase the vital power already emitted by the coffin and the vault. In chapter 68 of the Books 


\section{The religious system of China}

vol. I

of the Early Han Dynasty (I.12) we find this practice mentioned in connection with the burial of Hwoh Kwang, father in law to the Son of Heaven and generalissimo of the army in the first century p.301 before our era (see p. 239); it is there spoken of as 'a piling up of the thick ends of yellow intestines'. Su Lin ${ }^{1}$ a learned author living in the first and second centuries, explains this expression as follows :

«The yellow wood of the heart of cypress trees was accumulated outside the coffin; hence the text speaks of yellow intestines. The thick ends of the pieces ( $i$. e. those which, when on the trunk, are nearest the root), were all turned towards the centre of the cave, and therefore the text speaks of an accumulation of the thick ends.

In describing the funeral rites of the modern Chinese, we have shown that people believe the corpses of their ancestors emit such influences from the grave as may enable the offspring to live to a great age, and that this conception is particularly illustrated by their dressing their dead in robes stitched all over with characters representing long life (p. 63) and by their having the coffins nailed down by old men (p. 97). Now the conclusion is natural that this belief is intimately connected with the ancient practices of stuffing the mouths of the dead with life-emanating products of Nature and of surrounding their bodies with this same sort of things, nay, we may even suppose that it virtually originated in these practices.

A few words remain to be said on the other kinds of timber which, according to Chinese books, were used for coffins in former ages. Apart from a few sorts too rarely mentioned to deserve any special notice, are the following :

1. The Chang. This is the famous camphor tree, which grows all over southern China and is still so abundant in the south-western provinces as to supply most of the timber required for the watercraft on the Yang-tszĕ river. That its strong-smelling, hard wood is superior to almost any other kind of timber in resisting insects and fungi, is a fact generally known; moreover,

\footnotetext{
1 A short biographical notice of this man is to be found in the Memoirs of the Three Kingdoms, ch. 21, I. 21.
} 


\section{The religious system of China \\ vol. I}

this tree is an evergreen, and it is accordingly ranked by the people on a level with the pine and the cypress as a depository and dispenser of vital power.

2. p.302 The Kia. This is described by the 'Rh ya - a vocabulary dating probably from pre-Christian times - as a Ts'iu with small leaves ; and as the Shwoh wen, a dictionary composed in the first century of our era, identifies the Ts'iu tree with the Rottlera, it is not improbable that the Kia is simply a variety of the latter, the excellent qualities of which have been explained on page 294.

3.The P'ien. This tree is found in the provinces south of the Yang-tszĕ. It furnishes excellent timber which, according to Wells Williams, is much used for cabinet ware (1ㅜ) $)$.

4. The Tung, more commonly called Wu-t'ung. This is probably the Sterculia Platanifolea (311), a stately, large-leaved tree growing in the central and southern provinces of the empire, at least down to the latitude of Amoy. It produces an excellent light timber, much used for fine carpentry of all kinds, for musical instruments and the like. "The 'Rh ya calls it ch'en, because it is suitable for the manufacture of coffins" (312) ; in point of fact we find in the oldest Chinese documents the word ch'en very frequently used to denote an inner coffin.

« This word denotes the coffin nearest the body, and the wood got the name ch'en from the fact that it was placed next to the body. (313)

By the way we must place before our readers a curious extract from the $L i$ $k i$ (ch. 14, I. 22), referring to the manner in which in pre-Christian ages wood was procured in the empire for imperial coffins.

«When a Son of Heaven dies, the foresters repair to the trees growing on the spot assigned for sundry sacrifices, and have those fit for coffins and a vault cut down. If there be not wood there in sufficient quantity, the sacrifices are abolished, and the men connected with the place have their throats cut. $(\underline{314})$ p.303

Coffins, objects of great solicitude.

Coffins and vaults being intended in olden times for the important object of preserving the dead from decay and furthering their resuscitation, they 


\section{The religious system of China}

vol. I

must, as a natural consequence, have been objects of great solicitude. The ancient writings prove that such was the case in point of fact. It is recorded in chapter 11 of the Li ki (I. 16) that a scion of the house of the Rulers of Lu,

« Heu Muh by name, said : "I have heard Hien-tszĕ (a disciple of Confucius) say in reference to the rites of mourning, that mourners are not allowed to neglect thinking profoundly and long of the dead, and that, in purchasing coffins, they must pay minute attention to the same, outside and inside. When I die, let it be so with mine. (1ㅗ)

When Confucius was Governor of the town of Chung-tu (see page 292), he even went so far as to consider himself in duty bound to assume a paternal care over all the coffins within the pale of his government. His 'Domestic Discourses' $(\underline{316})$ relate on this head :

«When he had just entered upon his functions as chief magistrate of Chung-tu, he enacted rules for feeding the living and burying the dead. The old people and the young were made to eat different kinds of food, the strong and the weak to follow different professions. Males and females kept apart from each other in the streets, and on the roads lost things were not picked up by others. Vessels were not fraudulently carved; the coffins were made of timber of four inches, the vaults of wood of five inches. The hillocks being used for graves, no tumuli were raised over the latter, neither were trees planted upon them. When these regulations had been in operation during one season, all the feudal princes of the West imitated his example. (317)

Where the Master preceded, the disciples naturally followed, and encoffined the sage with a strict observance of the rules he had himself laid down.

«After the death of Confucius, Kung Si Ch'ih took upon p.304 himself the direction of the coffining and the burial. The coffin of Sterculia wood was four inches thick, and the cypress vault five inches. (1ㅗ)

The Chinese records in general contain numerous passages which point unmistakably to the prevalence, throughout the realm and in all ages, of a conception that it is among the most sacred duties of children to bestow great care upon the coffins of their parents. It would be but a waste of time and 


\section{The religious system of China \\ vol. I}

space to insert here a selection of such passages. When speaking in the latter part of this chapter of the coffins of modern times, we shall show that the said conception has culminated in the custom, still generally prevalent now-adays, of presenting coffins to parents while there is not as yet the least prospect of their being wanted by them, and that such an act is considered one of the greatest marks of affection sons can show to the authors of their being (page 325).

The expectation of a bodily resurrection, which prompted the ancient Chinese to pay so much attention to coffins and grave vaults, also led them to make provisions with regard to the coffins and vaults to be used for themselves after death. Two instances of vaults prepared during life the reader will already have noted, the one relating to a Minister of War in the kingdom of Sung (p. 289), the other to the Emperor Shi Hwang (p. 290). The Li ki moreover says (ch. 11, I. 30) :

«When the ruler of a state ascends the throne, he has his innermost coffin made; it is varnished once every year and then stored away. (319)

And in ch. 27 (I. 19) we read :

« Tseng-tszĕ asked : "When the ruler of a state crosses the boundaries of his territory, his necessaries for three years and his innermost coffin are carried in the rear. If he dies abroad, what are then the proceedings when he is brought back into his own state ? (320)

The emperors of succeeding dynasties seem to have held these rescripts in esteem during a long series of ages, for they were still complied with as late as the eighth p.305 century, when Huen Tsung of the Thang dynasty abolished them. The New Informations on the Great Thang Dynasty state on this head :

« Huen Tsung was on a tour of inspection in the north. Near a pass on the road along the slopes of the Thai-hing mountains he came across a cart loaded with a coffin. He asked the bystanders what there was in that cart, and was told: "A coffin. The Books of Rites prescribe that, when a Son of Heaven ascends the throne, he shall have his inner coffin made and have it varnished once a year, to show that, though 


\section{The religious system of China \\ vol. I}

he is alive, he does not forget his death. Its being carried in his rear on a cart when he goes abroad, is also an institution of the ancient sovereigns". But Huen Tsung said: "Why should we maintain this custom !" and he ordered the coffin to be burnt. Since that time the emperors have gone abroad without a coffin in their rear. (321)

Notwithstanding this strong and general partiality to being buried in the most substantial boxes procurable, there have existed among the ancient Chinese eccentric spirits, whose claims with regard to the treatment of their mortal remains were diametrically opposed to the hobbies of the masses. Foremost among these stands Chwang-tszĕ, a philosopher who is believed to have lived four centuries before our era and whose writings we have had occasion to quote on page 289.

«When he was at the point of death, his disciples resolved to give him a rich burial, but Chwang-tszĕ said : "I consider heaven and earth to be my coffin and vault, the sun and moon to be a double piece of jade, the stars and planets to be pearls, and all the products of nature a supply of presents bestowed upon me; are not then the articles required for my burial ready at hand? Why will you add anything to these ?" "We fear, replied the disciples, that ravens and kites will devour our Master", but Chang-tszĕ returned: "Above the ground man is eaten by ravens and kites, and under the ground p.306 by molecrickets and ants; will you snatch me away from the former, to deliver me over to the latter ? To what good end could such a deed in favour of the one party tend? (322)

This extract strongly confirms the conclusions, arrived at in the preceding and the present chapter, as to the chief object of the custom of stuffing the mouth of the dead with jade, pearls and so forth, and of interring their bodies in coffins. It shows indeed that Chwang-tszĕ was perfectly aware that all these things were intended to surround the dead with the beneficial influences of the universe, inclusive of those of the sun, moon and stars, which heavenly luminaries bestow life on earth; but he pleaded the utter uselessness of those things, because even in their absence the good influences of Nature were concentrated around the body. Of quite a different sort were the 


\section{The religious system of China \\ vol. I}

conceptions which, two or three centuries later, induced a certain Yang Wangsun to refuse to be buried in a coffin. These were evidently very remarkable in the eyes of contemporary historians, who deemed them worth recording in the standard annals of the empire. Wang-sun owes his admission amongst the immortals of history solely to his excentricity on this point, for there is nothing else noteworthy on record about him.

«Yang Wang-sun, says ch. 67 of the Books of the Early Han Dynasty, lived in the time of the Emperor Hiao Wu (B. C. 140-86). He applied himself to the arts and doctrines of Hwang-ti and Lao-tszĕ. His possessions amounted to a thousand pieces of gold, so that he could richly provide for his sustenance and during his life afford himself everything. When he had fallen so sick that his death became imminent, he gave the following instructions to his sons : - "I desire to be interred quite naked, in order that I may return to the original matter out of which I was created ; this my will you may certainly not depart from. When I shall have breathed my last, then make a linen bag, put my body inside of it, and depose it in the earth at a depth of seven feet; after that, pull off the bag over my feet, so that my body may come into immediate contact with the earth.

The sons wanted to keep silent about these instructions and not execute them ; yet they were conscious that it is a matter of no small importance to disobey the dispositions of a father. Hence they resolved to carry out his will, but again felt a great aversion to doing so. Finally they went to see Khi Heu, Wang-sun's friend, who gave them a letter for him of the following purport :

"You are dangerously ill, but I have no opportunity to call on you, as I must go up to the temple of my ancestors. I hope you will keep up your vital spirits and watch well over your mental faculties, also that you will have recourse to physicians and medicines, and take good care of yourself. I have heard about your instructions to be interred naked. If taking for granted that the dead have no knowledge, I have nothing to object against this plan: but suppose they have consciousness, then you intend destroying your own body under the earth ! In your stead I would not take it upon myself to appear naked 


\section{The religious system of China}

vol. I

before my ancestors. Moreover, the Classic of Filial Devotion ${ }^{1}$ says : 'Make for them a coffin and a vault, clothes and shrouds'. This also is a rescript left behind by the Holy Ones; why, therefore, are you so narrow-minded as to stick exclusively to what you have learned to be right ? I hope you will weigh well these my arguments.

p.308 Wang-sun's reply was of the following tenor. "I know very well that the ancient sovereigns have made laws and rites, in order to check the indifference of human nature with regard to parents. But the present generation goes much further than they went; hence I wish to lead the world into the right track by having myself buried naked. A luxurious burial is of no essential advantage to the dead, and yet people emulously try to excel each other in squandering money and wealth, placing this under the ground, there to rot away, in consequence of which the dead are sometimes interred to-day and exhumed to-morrow (by robbers); - in what respect does this really differ from exposing their bones to the sun in the open field?

But furthermore, death is a dissolution when life is finished, the returning of a being to its origin. If this returning have free scope and no obstacles be placed in the way of such dissolution, then the said being is absorbed into the original matter from whence it sprung, there to be reduced to an indistinct, shadowy condition, in which there is neither sound nor form ; it is then absorbed into the bosom of Tao. But if you adorn it on the outside to make a show of it before the public, and isolate it from the matter out of which it was produced by interring it in an opulent way, you prevent both its returning to the earth and its dissolution, so causing it to miss its destination. Moreover, I have been taught that the vital spirits are the property of the heavens, and the body and skeleton that of the earth, that those vital spirits, on leaving the body, return to the original matter from which they have sprung, and that they are therefore called kwei, this word meaning 'to return'. The corpse then alone remains p.309 behind

\footnotetext{
1 Hiao king. A spurious production, said to have originated with Confucius, but it is
} evidently a later compilation. 


\section{The religious system of China \\ vol. I}

on the spot like a clod of earth; how could it possibly have knowledge ? Dress it in silk, isolate it by means of coffins and a vault, tie the limbs and trunk together, put jade in the mouth, to prevent dissolution - it is all the same - you will have worried yourself about a mass of rotten flesh, which after a thousand years, when the coffin has decayed, shall return to the earth notwithstanding, in this way answering to its natural destination. To submit one's self to the natural order of things as here described, is better than to dwell for a long time like a stranger in a grave. In ancient times, when the Emperor Yao was buried, they used a hollow tree for a coffin and Dolichos creepers for coffin-bands; in digging the pit they did not disturb the springs of ground-water, but they took care that the smell of death should not escape to the surface. Acting in this manner, the Holy Sovereigns found it easy to combine the interests of the living with a decent burial of the dead ; indeed, they did not waste human labour upon such useless matters, neither did they destroy wealth for things in favour of which no man can allege any good. The present fashion of squandering away one's possessions by burying the dead in a grand style and thus placing obstacles in the way of their return to the earth, has for its object to effect something of which the dead are not conscious and to attain that which lies beyond the power of the living ; I call it a double self-deception, and Oh ! I will not do like the others". - Khi Heu confessed that Wang-sun was right, and thereupon the latter was buried naked.

p.310 The above theories on the nature of death pronounced by Yang Wang-sun by no means represent his private opinion alone, but are those generally set forth in the Chinese writings of the pre-Christian era. In our Second Book they will be carefully reviewed in their full extent. The school of Hwang-ti and Lao-tszĕ, of which, as the extract says, Yang Wang-sun was a partisan, is better known in Europe as Taoism. It taught that perfection in this life and the highest bliss in the next, immortality itself, might be obtained by perfectly assimilating one's self with Nature and the Universe. Hence it was most natural for the philosopher to long for a speedy dissolution of his body in the earth and for a quick assimilation of his vital spirits with the heavenly 


\section{The religious system of China}

vol. I

spheres, in short, for what he calls an absorption into the bosom of Tao. More light will be thrown on this subject in our Third Book, which is to be exclusively devoted to Taoism.

Another instance of a man who refused to be buried in a coffin or grave vault, has been deemed worthy of a place in the annuals of the Han dynasty. When Lu Chih, a high official, in A. D. 192

« was on the point of breathing his last, he ordered his sons to bury him in a poor style in a pit in the ground, without either coffin or vault, and with nothing on his body except a single piece of cloth. (323)

Other instances of a similar description are on record. But it would be a waste of time and space to reproduce them here, the philosophical reasonings which prompted them, being in each case obviously much the same as in the instance of Yang Wang-sun.

Among the men of letters of the Han dynasty there are some who severely rebuked their contemporaries for making the coffins of the dead objects of extravagant solicitude. Pre-eminent among them stands a certain Wang Fu. In the first half of the second century this man composed a book entitled Ts'ien fu lun, p.311 'Disquisitions by a Man living in Seclusion', in which he censured, often with unsparing sarcasm, many practices and doctrines of his age, thus bequeathing to posterity a rich mine of information concerning usages and notions prevailing at the time.

«The sage ${ }^{1}$, he wrote, informs us that, anciently, those who buried their dead covered them up thickly with firewood and interred them in the open fields, with no tumuli, nor trees on the grave; further he tells us that the time of mourning was not of a fixed length and that the holy men of later generations have altered this state of things by introducing coffins and vaults. The coffins they made of the wood of the Tung tree and the cords wound around them of Dolichos creepers; they were careful not to inhume them so deep as to reach the ground water, or so near the surface that the smell might escape.

\footnotetext{
1 Confucius, to whom the appendixes of the Yih king, in which this passage occurs (see page 281), are generally ascribed.
} 


\section{The religious system of China \\ vol. I}

Succeeding generations made them of the timber of the Ts'iu. (see p. 302), the Rottlera, the Hwai, the Cypress, the Tok and the Ch'u, each taking for the purpose the trees growing in his district. Glue and varnish were applied, the nails were planed away and the pegs levelled off, so that the seams became invisible; their solidity might be sufficiently relied on, and they were just good enough for use. All such things are allowable; but afterwards the notable families in the capital became obstinately bent upon the use of Pine and Rottlera timber from the Kiang-nan region, and upon P'ien and Nan timber from Yü-chang (Kiang-si) ; yea, even in the country, till beyond the frontiers, people vie with each other in imitating these extravagances.

Now, as to the said Pine and Rottlera timber - Yü-chang, whence it is exported, is extremely far off. It grows there in deserted valleys, deep in the mountains, on peaks ten thousand feet high, in glens hundreds of fathoms deep, which can p.312 only be reached by crossing steep mountain ranges. The trees must be sought for many days in succession along untrodden paths, steep and rough, open to all kinds of dangers and obstructed by rocks and stones. When they are at length discovered, many months are required for felling them; and when this work is finished, multitudes of people must be assembled ere they can be removed from the spot, and files of oxen have to be employed to carry them to the water-side. Then they are floated down the Yang-tszĕ, entering the vast lakes, whence they have to be brought up the Hwai and the Hwang-ho, against the stream, over thousands of miles. At last they arrive at Loh-yang capital. Here labourers set to work to cut and plane them during several days and months, and we may reckon that upon the fabrication of one coffin thousands, nay, tens of thousands of men are employed before it is finally fit for use. As it weighs over ten thousand pounds, it cannot be lifted up unless a great multitude of people are at hand, nor can it be moved from the spot without big carts. Throughout the region which extends over ten thousand miles between Loh-lang (on the borders of Corea) in the east, and Tun-hwang (in Kansuh province) in the west, the people outvie each other in the use of such coffins. The waste of 


\section{The religious system of China \\ vol. I}

labour entailed by this abuse and the damage it causes to agriculture makes the heart bleed. (324)

This extract is likewise interesting as showing, that already in those early times the soil of the empire over large areas had been stripped of its forestgrounds to such an extent, that it could no longer produce sufficient coffintimber for the needs of the population. - In the course of centuries this state of matters has not in the least p. 313 improved. It is a well-known fact that the northern provinces of China, in so far as they have come under the observation of foreigners, produce no large trees worth mentioning; the virgin forests of Kiangsi, of which Wang Fu speaks, no longer exist; in Kwangtung and Kwangsi forests are conspicuous by their absence. Fuhkien too is denuded; there is some timber on the banks of the Min river, but these forests are being recklessly destroyed to supply the market of Fuhchow, whence much wood is exported to the sea-ports of the Empire. Virtually the remotest corners of China have to be ransacked for durable, good coffin timber, and importation from foreign countries is necessary to make up the deficiency. If it be true that destruction of forests changes the climate, it is certain that the partiality manifested by the Chinese since times of old for preserving their dead against decay by using coffins and vaults of the best sorts of wood procurable, has been one of the great causes of the terrible droughts and floods, which regularly visit large tracts of the country at intervals. For a long series of ages the people in their ignorance have suffered themselves to be decimated by such catastrophes as a sacrifice to the bodies of their dead. No Chinese government has ever created a forest-department to restore what the people so recklessly destroy ; we may even suppose that each dynasty, instead of extending its paternal care thus far, has felt gratified by the denudation of the soil, as forests afford good shelters to rebels and render their extinction the more difficult.

The scarcity of timber entailed by the wanton destruction of forests readily accounts for the fact that, from the Han dynasty downwards, double, triple and quadruple coffins are scarcely ever mentioned in Chinese books, and that grave vaults gradually fell into disuse at the same time. In the eleventh century vaults had become so obsolete that Szĕ-ma Kwang wrote : 


\section{The religious system of China}

vol. I

«Although vaults were instituted by the holy ancients and have been in vogue since times of old, it is better not to use them, for the wood of the boards decays in the long run, which causes the pit to become too spacious, so that it no longer tightly encloses the dead. Moreover, when Confucius buried Li, he had a coffin only, and no vault, and the sage approved of the poor burying their dead without a vault (p. 291). If people at the present time do not use vaults because of their poverty, they abstain from using them because they desire to secure the repose of their p.314 dead. (325)

As for the Chinese of to-day, there is every ground for believing that the use of grave vaults has entirely disappeared from their funeral customs. It is possible they are still in vogue in some parts of the Empire, and for persons of imperial blood or dignitaries of the highest ranks, but we have no information on this head.

In perusing the voluminous Dynastic Histories of China, one comes across several instances of persons who, when giving instructions about their own obsequies, ordered that economy should be observed with regard to the same and that the coffin should be of the plainest description. This suggests not only that good timber was scarce and dear, but also that people in general were so slavishly addicted to wasting their money upon the receptacles for their dead, that men of higher intellectual standing felt obliged to raise their voices against such extravagance. Coffins being thus deemed of the highest importance for the dead, we can well understand why, in ancient China, it was considered a calamity to be interred without a vault, and how it is that some grandees have gone so far in their animosity against enemies as to forcibly deprive them of a burial in a coffin. As to the first point, we read in the Cheu li :

«Those among the people who do not rear cattle, have no victims for their sacrifices; those who do not plough have no full vessels when offering ; and those who do not plant trees have no grave vaults. (326)

As illustrative of the second point we borrow the following episode from the Books of the Early Han Dynasty (ch. 93). During the reign of the Emperor Ngai (6 B. C. - A. D. 1), Tung Hien, a generalissimo of the Empire, fell into 


\section{The religious system of China}

vol. I

disgrace with the Sovereign in consequence of the intrigues of Wang Mang, a grandee who at that time occupied the most influential position in the Empire and soon afterwards dethroned the emperor, proclaiming himself p.315 the Son of Heaven. Being deprived of all his dignities, Tung Hien committed suicide on the same day, together with his wife. The family in consternation buried both corpses under the cover of night. But Wang Mang, wishing to convince himself that the suicide had been committed in fact, caused his victim to be disinterred, and having examined the corpse in a prison, he had it buried again, but without a coffin. At his instigations a certain official then presented a memorial to the Throne, in which he accused Tung Hien's father of having carried his arrogance so far as to bury his son in a red coffin which was not only adorned with paintings and the colours of the four seasons, but also with a blue dragon on the left side, a white tiger on the right, and a sun of gold with a silver moon on the top. Further he insinuated that the old man had encoffined the corpse with ornaments of jade, with pearls and badges of rank, as one was wont to do in the case of an Emperor, declaring that for all these reasons he felt obliged to propose the banishment of the father and the confiscation of his property. Meanwhile another official, an intimate friend of Tung Hien, had unearthed the desecrated body, dressed, encoffined and reburied it. This aroused Wang Mang's indignation to such a pitch that he had the man flogged to death.

This tragic episode is also important as showing that, during the Han dynasty, only grandees were entitled to a burial in a red coffin, and that they jealously watched against encroachments on this prerogative by officials who had fallen into disgrace and consequently no longer belonged to their order. We read also in ch. 64 of the Books of the Later Han Dynasty that Liang Shang father-in-law to the Emperor Shun, who reigned between A. D. 126145, was buried in a vermilion coffin procured by the official department specially intrusted with the care of providing coffins for the court. That the use of red coffins by the official classes continues to the present day we shall have occasion to state on page 322 .

The ancient Chinese showing themselves so strongly opposed to interment without a coffin, their rulers naturally fell into the habit of bestowing coffins upon deceased men of state as a mark of favour. Such gifts being a 


\section{The religious system of China}

vol. I

recognition of services rendered the Government, much value was set on them ; hence we find them frequently recorded in the Dynastic Histories as matters of high p.316 significance. In most cases they were connected with a donation of money and valuables for equiping the deceased, carts, horses and other requisites suitable for the burial.

\section{Coffins representing the Heaven.}

Many a time we have had occasion to state, that in China it is considered a matter of extreme importance to place the dead in graves which are situated under the beneficial influences of the Cosmos, that they may feel happy and comfortable there in every respect and thus be found willing and able to bestow from thence blessings upon their offspring. That this conception is already very old, will be proved from the native literature in ch. XII of the next part of this Book. We have also seen that the ancient Chinese, wishing to facilitate the resurrection of their dead, surrounded them with jade, gold, pearls, timber and other things imbued with influences emitted by the heavens, or, in other words, with such objects as are pervaded with vital energy derived from the Yang matter of which the heavens are the principal depository. Now combining these conceptions and practices, the reader will have no difficulty in understanding why they used to paint their coffins in such a way as to make them represent the Universe in miniature. To this custom we must now call the reader's attention for a few moments.

The narrative of Tung Hien's tragic end, reproduced above, has shown that it was an established custom with the ruling classes during the Han dynasty to decorate their coffins with 'the colours of the four seasons'. No doubt these colours were blue, red, white, and black, these having always been identified by Chinese philosophy respectively with the Spring or the East, the Summer or the South, the Autumn or the West, and the Winter or the North (comp. p. 122). The same narrative further informs us, that the coffins of grandees in those times displayed "a blue dragon on the left side, a white tiger on the right, a golden sun and a silver moon on the top" ; moreover, the Books of the Later Han Dynasty state that the imperial coffins "used to be decorated and painted with a sun, a moon, a bird, a tortoise, a dragon and a tiger" (327). These four animals denoted in ancient China the 


\section{The religious system of China}

vol. I

four quarters of the celestial sphere, the eastern quarter being called the Azure Dragon, the p.317 southern the Red or vermilion Bird, the western the White Tiger, and the northern the Black Tortoise. For the sake of convenience we may draw up all the above cosmogonal elements in a table as follows:

\begin{tabular}{|l|l|l|l|}
\hline East & Spring & Blue & Dragon \\
\hline South & Summer & Red & Bird \\
\hline West & Autumn & White & Tiger \\
\hline North & Winter & Black & Tortoise \\
\hline
\end{tabular}

Likewise during the Thang dynasty the imperial coffins

« displayed a sun, a moon, stars and asterisms, a dragon, a tortoise, and their appendages, painted on the lid. (328)

And on page 181 we have seen that the modern Chinese still embroider dragons and a tiger on the drapery of their catafalques, on the top and the two opposite sides.

This partiality for surrounding the dead in their subterranean dwelling with the Universe in miniature explains the custom mentioned on page 91, of stretching them in their coffins on a board with seven holes or circles arranged in the same order as the stars of the Great Bear. In China, this asterism - called the Northern Bushel on account of its shape - anciently held a prominent place among the ruling powers of Nature. The Shi ki says :

« The seven stars of the Bushel, which are styled the Revolving Pearls or the Balance of Jasper, are arrayed so as to form a body of seven rulers. The Bushel is the chariot of the Emperor (i. e. of Heaven). Revolving around the pole, it descends to rule the four quarters of the sphere and to separate the Yin and the Yang ; by so doing it fixes the four seasons, upholds the equilibrium between the five elements, moves forward the subdivisions of the sphere, and establishes all order in the Universe. All these functions have devolved upon the Bushel. (르)

It is clear that this passage means this much : - the Great Bear turning around the pole of the heavens once a year, it stands, at the same hour of the night, in each of the four seasons in a different quarter of the sphere, and 


\section{The religious system of China \\ vol. I}

thus marks out p.318 on the latter the seasons, just as the hand on a clock indicates the hours; nay, it even compels the whole sphere to move round with it, thus producing the four seasons, the rotation of which is actually the course of Nature. Now then, it is quite natural that a people which was in the habit of depicting the heavens and the seasons on their coffins, should add thereto a representation of the power which, as they believed, brought about their rotation and was thus the real creator of all life and all the blessings of Nature.

So far as we are aware, the pre-Christian literature of China does not contain any clear reference to the boards of the seven stars. In the Tso ch'wen it is stated that Yuen, a feudal lord of the state of Sung, in 515 B. C. said to his ministers :

« If by your energetic help I save my head and neck till I die a natural death, I pray you, do not then let the flat piece of wood, which will serve to support my body, equal that used for the former rulers. (330)

Though this passage unmistakably shows that this piece of wood was an object of great solicitude, yet there are no means of ascertaining whether it was a seven stars' board or not. For the first time we meet with the name in Yen Chi-thui's Domestic Instructions, written in the sixth century (see page 42). In his post-mortem dispositions recorded in this book, the author prescribed as follows :

«I must have a coffin of pine wood, two inches thick, and on the spot where my body is to lie, nothing may be placed but a seven stars' board. ( $\underline{331}$ )

Among the rescripts concerning the obsequies of Tai Tsung, an emperor of the Thang dynasty who died in the year 779, we read :

«A seven stars' board was placed inside the Rottlera structure (i. e. the coffin), and the things which were to be arranged collectively underneath were all placed below it first. (332)

The Kia li also prescribes the use of this board, and so does the Ta Ts'ing thung $l i$ in its precepts regulating the funeral rites of the sundry classes of officers and of the common people. p.319 


\section{The religious system of China}

vol. I

Coffins of the present time.

The great interest attached to coffins in times of old has abated but little in the course of ages. Even at the present day they are considered indispensable for the repose of the dead; the poorest man is provided with one, though it may be of the cheapest wood and of the worst construction.

As a rule they are made as strong and well as the means of the family permit. Hence, as in bygone ages, they are mostly of very thick boards. The

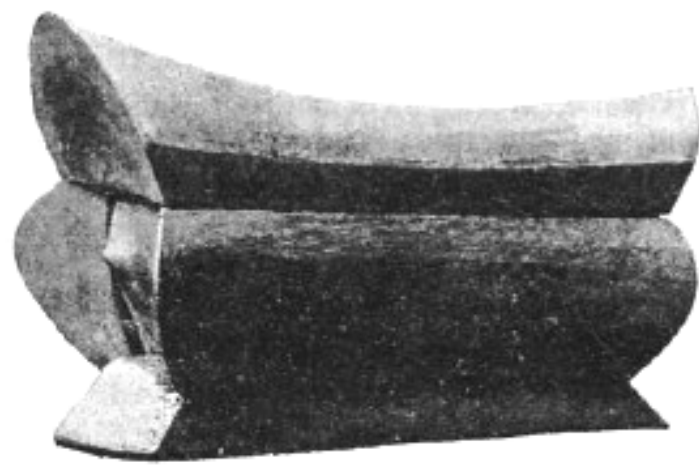
two planks on the right and left, as also the lid, are rounded on the outside surface, being in most cases cut out of the tree in this shape ; this gives the coffin a very substantial appearance and at first sight reminds us of the trunk of a tree (see Fig. 22). The bottom is Fig. 22. Closed coffin of superior quality. flat, and very thick. Like the lid, it projects a few inches over the two sides, and these, as well as the bottom and the lid, project beyond the small square planks which form the ends of the coffin. In a great many cases, the round surface of the lid slopes gently up at both ends, but more considerably at the head of the coffin than at the foot.

In order that the lid may fit well upon the case, the edge of the latter forms a raised rim (Fig. 23) which fits into a corresponding furrow in the four sides of Fig. 23. Open coffin of inferior quality.

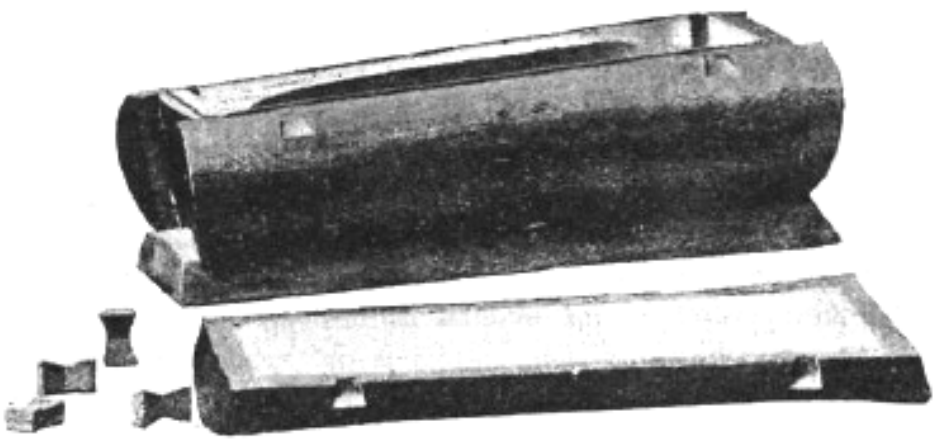
the bottom of the lid. When the lid is about to be fixed on the case, a mixture of lime and oil prepared from the fruits of the Thung tree is laid upon the rim all around, to make the seam close hermetically (comp. page 95); in addition, the seam is caulked on the outside with putty of a similar kind. In 


\section{The religious system of China}

vol. I

constructing the coffin, the carpenters fill all the seams in the six boards in like manner, this being calculated to prevent water and moisture from penetrating to the corpse when in the grave. Besides the putty mentioned, there are other p.320 such like preparations used for the purpose. Into the composition of some of these enters the so-called 'dripping blue', which is resin, pitch or gum obtained from pine trees; other sorts are prepared from bee's wax and similar matter.

Of many coffins of good quality the seams on the outside, after the caulking, are pasted over with strips of linen or of thin, tough 'cotton paper', mi tsoá, and are then varnished. The whole inside surface being often dealt with in this way, all the pores of the wood are perfectly closed. In many cases also, the coffin is entirely pasted over on the outside, and then covered with a coating of varnish or lacquer, especially when the corpse has been placed therein and the burial has to be postponed for a considerable time (comp. p. 106). In such instances the varnishing is repeated from time to time, if the family think it necessary. Some people prefer a yellowish coating to a black one, because it is said white ants do not so easily gratify their voracity upon yellow objects.

A coffin of good, substantial wood, carefully caulked and made in the way above described, may serve to preserve a corpse unburied for years without emitting any smell. We have ourselves visited many buildings enclosed on all sides, where encoffined bodies were stored up by scores without any offence to the nasal organs. But coffins of inferior quality, destined for the p.321 poor, are scarcely ever caulked, nor have they even a raised edge to fit into the lid. As a matter of course, such receptacles are only made with a view to immediate burial, before decay sets in.

On page 95 we have had occasion to state that the lid is fastened to the case by means of dove-tailed wooden pegs, each of which is forced tightly into an excavation of a corresponding shape, made over the seam. These pegs, of which there are two on each side, are in Amoy called gûn tiāng, 'silver ingots', or gûn tiāng sún, 'joints like silver ingots', on account of their shape; from Fig. 23 it may be seen how they are used. In most cases, especially if the interment has to be deferred and the coffin must be 


\section{The religious system of China}

vol. I

varnished, they are, after being inserted in their places, planed or chiseled away on the outside and caulked all around, so that, after the varnishing, the eye can scarcely discover them, That the use of such pegs dates from antiquity has been shown on page $285 \mathrm{seq}$. ; they are also an instance of the tenacity with which people cling to usages connected with the sacred observances of the dead.

The interesting fact that custom does not allow of more than two nails for fastening down the coffin lid, has likewise been noted before ${ }^{1}$. Only in the case of coffins of the poorest quality, which have no pegs, are four nails used, one near each corner. In Peking, it is said, the lid is usually nailed at the sides in three places, two nails on the right hand side for a male, and two on the left for a female 2 .

It must still be noted that families in easy circumstances cling to the ancient custom mentioned by the $\mathrm{Li}$ Ki (see page 287) of lining the receptacles of the dead. Coarse red linen or cotton stuff is used for this purpose. No lining is affixed to the lid, but instead of this, a wooden frame over which the same material has been nailed or pasted, is fitted into the coffin over the dead before the lid is put on.

p.322 As we have shown on page 315 , it was during the Han dynasty a prerogative of official persons to be interred in red coffins. This is still so at the present day. The Ta Ts'ing thung li prescribes that,

« in case of persons on whom the first of the nine degrees of nobility has been conferred, the ornamented coffin shall be varnished or lacquered red, and decorated with gilt flowers, while red coffins must be used for grandees of the second and the third rank of nobility, as also for the officials of the highest degree downwards. (333)

\footnotetext{
1 See p. 95. It is, at Amoy, a favourite saying in allusion to a noisy individual, intruding and importunate, that "he will not be quiet until four nails have been driven into his coffin": ting si ki ting tsiū tiāng-tióh, in other words, that his death and subsequent coffining with the customary two nails will not suffice to impose silence on him, but that double the number of nails will be required for this purpose.

2 Catalogue of the Chinese Collection of Exhibits for the International Health-Exhibition in London, 1884, p. 61.
} 


\section{The religious system of China}

vol. I

The ancient custom of making a microcosmos of coffins by ornamenting them with the principal subdivisions of the Universe (p. 316 sqq.) still shows faint signs of life among the people of Amoy. They seldom call the lid by its vulgar name of koà, 'cover', mostly preferring the word thien, 'heaven'; the bottom they call tōe, 'the earth', the sides respectively jit, 'the sun', and goát, 'moon'. The upper end they often style khoe thâo, 'the head of the Great Bear', and the lower end khoe bé, 'the tail of the Great Bear', which expressions owe their existence to the board of the seven stars which is still much in vogue, though not among the very poor. This board is not sold with the coffin as a natural appendage. It has always to be ordered apart from the coffin, and the price charged for it is exorbitant. This circumstance alone compels the poor to do without it.

Like most articles of common life, coffins are made and sold by the same individual in China. In other words, the workshops where they are manufactured, are also the sale rooms. Coffin-making is quite a separate business, by no means a work to be done by ordinary carpenters. Some few people add to this business a so-called ts'ái péh tièm or 'shop for decorative silks', where they sell all sorts of things required for the equipment of the dead in their coffins, such as lime, paper, pith, etc. ; they also supply sackcloth, soul tablets, and such like articles. These shops, which are in many instances kept by people who are not coffin-makers, should be carefully distinguished from the undertaker's-shops mentioned on page 13 and referred to in other places of the first part of this Book.

p.323 In many a town these is one or more streets in which most or nearly all the houses are devoted to the making and sale of coffins. Amoy possesses a street of this kind, called the koan-ts'â hāng or 'coffin lane'. In the same town the coffin shops go by the name of pán tièm, 'board shops', because in the local dialect receptacles for the dead are generally called pán 'boards'. This again must be ascribed to the disposition, generally manifested by the people and referred to already on page 95, to avoid calling matters of a disagreeable nature, like death and burial, and things reminding one of the same, by their true names ; they like to replace these by terms which call to mind matters and things harmless in themselves or good and beneficial to every one. This characteristic of the nation further explains the general use of 


\section{The religious system of China}

vol. I

the expressions 'longevity wood' and 'longevity boards' ${ }^{1}$ in various parts of China. We need scarcely say that these expressions undoubtedly stand in close relation with the fact that coffins have, since the remotest ages, served the purpose of surrounding the dead with vitality, thus enabling them to bestow on their offspring the capacity of living to a great age. Already in the Books of the Later Han Dynasty the term 'longevity receptacles' is used as a synonym for coffins.

Coffins vary considerably in both quality and price. Those of the very poorest description are made of thin, flat boards, or even of laths fastened together lengthwise and showing plenty of seams and breaks; these cost only two dollars a piece at Amoy, or even less. Fashionable people pay from two to three score dollars, for which sum they obtain a good coffin of rounded boards, each board consisting of one single piece of round, substantial timber. The poor, who cannot afford such an outlay, content themselves with coffins of similar appearance, the boards of which, on close examination, are found to consist of pieces of timber fitted together lengthwise, having their seams filled up with putty. The wealthy, in their anxiety to secure wood of first-rate quality and durability, often pay many hundreds of dollars for a single coffin. Such an expensive article is often over one meter high and extremely heavy and cumbersome, the boards being exceedingly thick.

In the south-eastern provinces of the empire nearly all good p.324 coffins are made of the wood of the San tree (Cunninghamia lanceolata). This stately congener of the pine, fir and cedar is one of the finest trees of China, remarkable for the straightness of its trunk and for the deep green colour of its stiff acicular leaves. The wanton destruction of forests, which has been going on for ages also in the south, has there rendered big San trees extremely scarce, and this fully accounts for the high price of coffins made of substantial boards, because the size of the tree augments the value of the timber obtained from it. Trees of the pine and fir sorts having from the remotest times been in demand for making coffins on account of the reasons set forth on page 294 sqq., it is quite natural that the San tree, which produces wood of almost unequalled excellence, has always been specially

\footnotetext{
${ }^{1}$ In Amoy siū pán.
} 


\section{The religious system of China}

vol. I

used for the same purpose in the provinces where it grows. At any rate such was the case in the fourth century, as appears from the commentary written by Kwoh P'oh ${ }^{1}$ at that time on the 'Rh ya :

«The San, he says, resembles the pine. It is suitable for shipbuilding, as well as for coffins and pillars. It does not rot when buried in the ground.

The author of the Pen-ts'ao kang muh said :

«The San is peculiarly valuable for making coffins, because its wood does not fall a prey to white ants. (334)

Coffins procured during life.

On page 60 sqq. we have shown that, in China, it is customary for people who can afford it, to procure grave clothes during their life, and that these are often bestowed by children on the authors of their days as a highly esteemed present. Knowing this, it is not surprising to find that the same thing is often done in regard to coffins.

Persons of upwards of fifty or sixty years of age, whose means permit them, are supposed to have their coffins ready for immediate use. Many people prefer to buy the loose boards only, which occupy less room, as Chinese houses are mostly rather small. Some families store such boards away in the fowl-cot, it being a prevalent opinion that the excrement of these domestic birds renders the timber strong and better proof against decay in the earth. Often also, coffins procured during life are left for safe keeping in the p.325 shop where they have been purchased, or stored away in Buddhist temples, against a remunerative payment to the inmates. This has also the advantage of securing the owner against the risk of such evils as superstitious people assert may be caused by the presence of objects so closely connected with death as coffins are.

There are many instances of devoted sons saving from their earnings for a long time, in order to purchase a coffin or coffin-boards of excellent quality for their father or mother. The old man or woman is, of course, much

\footnotetext{
1 A. D. 276-324.
} 


\section{The religious system of China}

vol. I

gratified to receive such a gift ; yet the presentation is, as a rule, not made a matter of such formality and ceremony as in the case of grave clothes (see page 62). By the way we may note that it is also customary for well-to-do fathers, at the marriage of a daughter, to add to the outfit wherewith she is sent to the house of the partner of her future joys and sorrows, a coffin of gilded silver, a few inches in size. This is to signify the old man's willingness to provide his child not only with all the requisites of life in the form of a trousseau, but also with those of death, amongst which none is so important as the coffin.

\section{Superstitions connected with Coffins.}

That spoken words possess power and influence, is a belief of general prevalence in the Chinese empire. Already on page 95 we had occasion to draw attention to this fact. It prompts the people of Amoy to avoid calling a coffin by the right word for it, viz. $k o a^{n}$ ts'â, and to style it 'boards', or 'longevity boards', or 'longevity wood' - all innocent and even good omened terms as mentioned on page 323. The same people also use the expressions pán p'e, 'embryo of boards', and toā ts'ù, 'great house', the latter almost exclusively in combinations, such as jíp toā ts'ù and khiā toā ts'ù, 'to enter and to dwell in the great house', which means, in plain English, to be coffined.

As has been cursorily noted, coffins, even when empty, may bring ill luck upon the living. Some very superstitious people, especially of the female sex, are therefore accustomed to turn their faces the other way whenever they meet with a coffin, nay, to p.326 take to their heels and beat a retreat ; others pertinently refuse to enter a coffin shop, or even to pass through a street where the coffin makers dwell. In order to counteract or neutralize the bad influences emanating from coffins, people are in the habit of pasting upon the board of the upper and the lower end a sheet of paper of a red, evildestroying colour, inscribed with the character [], 'felicity', or [], 'longevity'. Such charms are considered sufficiently effective, written characters being, as we have often shown in many customs described in this Volume, not merely dead figures, but things essentially endowed with the faculty of producing the reality they represent. 


\section{The religious system of China}

vol. I

It would be a mistake to conclude from the above that dreaming about coffins portends ill luck. On the contrary, such dreams are generally believed to foretoken a high amount of bliss : they will raise the dreamer, his children or other descendants to official dignities, which, as the reader knows, are more coveted by a Chinaman than anything else. The reason of this is simply, that a coffin and a mandarin are both denominated by the same word kwan, while, moreover, the written character for coffin [ab] is composed of the elements [a], 'wood', and [b], 'a mandarin'. In the Books of the Tsin Dynasty we read that Yin Hao, a learned official living in the fourth century, who was famous for the smart replies he had in store for every occasion,

« on being asked how it came to pass that a man dreamt of coffins when he was to be raised to an official dignity, and of filth when he should acquire wealth, gave the following answer: "The mandarinate is essentially rotten and a prey to corruption; hence a man dreams of a corpse when he shall become a mandarin. And money is in truth merely filth and mud; consequently, when wealth shall fall to the lot of a man, he dreams of dirt". (335)

The reader knows that in China vital power is specially p.327 assimilated with the Yang, the chief part of the Cosmos, identified with light, warmth and life. He knows also that such products of Nature as are deemed to be imbued with shen, i. e. afflatus derived from this Yang element, have always been believed in China to be capable of strengthening the vital energy and consequently have been widely made use of as elixirs of life and as medicines. As such we have instanced the cock, jade, gold, pearls and the products of pine and cypress trees. Further it has been seen from this and the preceding chapter that, as a direct consequence of the said ideas, all these things have, since remote ages, been placed inside, upon and around the dead, in order to imbue them with vital energy and so, besides preserving them from decay and facilitating their resurrection, to enable them to bestow vitality upon their offspring, causing the latter to live to a great age, hale and healthy. Now combining these ideas with the idiosyncrasy of man in general, to believe that what one wishes really is, then it is as natural as natural can be that the Chinese should take it for granted that corpses, coffins and graves, when prepared in accordance with all the rules of the art of burial, 


\section{The religious system of China}

vol. I

become the ne plus ultra of seats of Yang matter, or, what is essentially the same thing, embodiments of shen afflatus. A coffin or grave therefore can, according to these reasonings, produce first-rate medicaments, healthrestoring, life-sustaining. Moreover, whereas things imbued with Yang counteract the influences produced by the element Yin, which the reader will remember is the great principle of darkness, cold and death standing in the Universe diametrically opposite to the Yang, parts of the equipment of corpses and parts of coffins and graves neutralize the effects of the Yin, in other words, they paralyze all agencies of evil and death assimilated with the latter element. As a matter of fact the Chinese do what these theories teach them must be salutary, deriving from their coffins and tombs both medicines for curing the sick and amulets for warding off evil.

When, in Amoy, a person who has attended the dressing or coffining of a dead body, feels indisposed, his family consider this a sure proof that his vital spirits have suffered by contact with the deceased, and they decide at once that the corpse must be applied to for an antidote. The wife of the sick man, or another matron of the family, immediately repairs to the house of death, There, with incense-sticks in her joined hands making obeisances to the coffin, she informs it of the object of her coming, p.328 and picks up some of the chips which the carpenter has cut away while levelling the pegs that join the case and the lid, or, if everything has already been swept away, she cuts off a few particles of wood from a corner of the coffin. Taking them home, she places them with some tea in a pot, makes a decoction from the mixture, and gives it to the sick man to drink as a medicine. Should the corpse have already been buried, a little earth is fetched from the grave and used instead, the result being, as people believe, just as effective. Persons who fall sick after attending at the exhumation of a corpse, are restored to health by a decoction of chips from the old coffin.

Turning over the leaves of the Pen-ts'ao kang muh, we find the following passage, quoted from the writings of Ch'en Tsang-khi, who, as we have said on page 201 , lived in the eighth century.

« Old coffin boards. - These are not poisonous; they conquer the influences of spectres, dissolve obstinate inner evils and pains in the 


\section{The religious system of China \\ vol. I}

heart and belly, and counteract asthmatic affections, as also perturbations caused by bad dreams. Those who are constantly under the influence of spectres and spirits should make a decoction of the wood in water and wine, adding a branch of a peach tree growing on the east side of the trunk, and they will vomit them out. (336)

As an additional rescript the Pen-ts'ao kang muh gives :

«When babies cry at night, kindle some old coffin wood and let the flames shine over them, then they will be quiet immediately.

As for evil-destroying amulets derived from coffins, as such nothing is in Fuhkien so highly prized as armlets of jade, which have been for years on a corpse in the grave (see p. 279). All of those we have seen on the wrists of the living, had partly or entirely turned black in consequence of their long contact with the mass of corruption. It is said, however, that some people cannot be persuaded to wear such disgusting ornaments.

In his Social Life of the Chinese (ch. 31 [vol. II, ch. XIII, p. 309]), Mr. Doolittle informs us that in Fuhchow iron nails which have been used in fastening up a coffin, are used as amulets.

« They are, he says, carried in the p.329 pocket, or braided in the cue. Sometimes such a nail is beaten out into a long rod or wire, and encased in silver. A large ring is then made of it, to be worn on the ankles or the wrists of a boy until he is sixteen years old. Such a ring is often prepared for the use of a boy, if he is an only son. Daughters wear such wristlets or anklets only a few years, or for even a shorter time.

The Chinese are by no means always logical in their superstitions. While on the one hand they use old coffin wood as a medicine, on the other hand they are obstinately opposed to cooking their food over it, saying that such a fire may emit influences which, entering the food, would poison those who eat of it. Old boards, obtained after a lapse of years when the family thinks it proper to exhume the corpse and transfer the bones to an urn of earthenware 1 , are consequently left about the spot as useless. Not even beggars will pick them up, although this class of people are not chary about

${ }^{1}$ For particulars on this head see the third part of this book, ch. XIII. 


\section{The religious system of China}

vol. I

laying their hands on whatever they can catch. Country people, however, sometimes use them for the construction of dams in wet rice-fields, for bridging over narrow water-ditches, for troughs to feed their pigs, and the like. If the wood has originally been of first-rate quality and suffered but little in the ground, the boards are not seldom used in the manufacture of circular and oval guitars, for, as the Chinese pretend, instruments made of such wood produce music of particularly agreeable sound. Already more than eleven centuries ago Chen Tsang-khi wrote :

« The very best among such old coffin boards which become better as they grow older, are those of San wood. When these are a thousand years old, they are imbued with shen afflatus, and they should then be used for making the sounding boards of harps. (337)

\section{Coffins for Children and Buddhist Priests}

Bearing in mind the fact that burying young children is, for reasons set forth on page 240 , not a matter of any solicitude, it is natural that little care should be bestowed on their coffins. Receptacles resembling those which are in vogue for up-grown people are only provided for children above the age of eleven or twelve. There are, however, no fixed rules of conduct for the people on this head. Their behaviour in each particular case depends p.330 upon the sex of the child, the affection of the parents and, most of all, upon their pecuniary circumstances.

Babies and very young children are usually encoffined in boxes made of six flat boards of thin wood. Such so-called bók á, 'small coffins', or khoeh á, 'boxes', are of such weak construction that they must inevitably be crushed to pieces in the ground under the weight of the earth. In most cases they are narrower at the foot than at the head. Of painting or caulking there is no question, neither is a board of the seven stars ever placed inside.

Children dying under two years of age are in a great many instances placed inside large mouthed earthenware jars, and thereupon buried in the ground, or deposited somewhere in the mountains or in the open fields. This convenient mode of ridding one's self of such corpses is especially practised by the poorest classes, jars being much cheaper than wooden boxes. 


\section{The religious system of China}

vol. I

Deceased members of the Buddhist clergy are either buried or burned. In the former case their coffins do not differ from those used by the laity ; but when one is burnt, he is placed in a sitting posture in a large square box which has a door or a slide in front, and so he is reduced to ashes with box and all. Details of such cremations we reserve for our Book on Buddhism. 


\section{CHAPTER V}

\section{On some other usages prompted by the belief in a resurrection}

\section{Washing and Dressing the Dead.}

p.331 The great solicitude manifested by the ancient Chinese to keep the bodies of their dead in a good condition, that they might at any time be fit to be re-occupied by the soul, naturally suggests their being very particular in subjecting corpses to a scrupulous cleansing before enclosing them in their coffins. The correctness of this inference is fully confirmed by the old books of the nation.

On page 16 sqq. we have already quoted such passages from the $I$ li and the $L i k i$ as show that, in pre-Christian times, the dead of rank were carefully washed with water prepared with rice, millet and other ingredients; that this water was boiled on a furnace specially built for the purpose, over fire-wood collected on a spot particularly assigned. Further those passages teach us that the basins, tubs and other implements used on this occasion were quite new, that the beard of the deceased was trimmed and the nails were pared with the utmost care, and finally that the hair, after having been washed, was bound up with ribbons and adorned with pins. We have further described how washing the dead and making their toilette is still a matter of great solicitude among the modern Chinese. The ancient books do not give any other information on this subject worth reproducing. Hence we need not dwell upon it any longer, but can proceed at once to what those books tell us about the manner in which the dead were dressed for the grave.

As already stated on page 36, the dressing of a dead body was usually done in three stages : first, they put on the body clothes, which proceeding they denoted by the character [] ; then came the so-called slighter dressing, 


\section{The religious system of China}

vol. I

and finally the greater or fuller dressing. These proceedings are referred to by the $\mathrm{Li}$ ki so frequently, as to fully justify the conclusion that they were p.332 matters of the greatest concern to the ancients. Yet these numerous references are very incoherent, extremely concise and of little interest; consequently we will not waste time and space by reproducing them. In the $I$ Ii, however, the dressing of ordinary officers and members of their families is described with so much elaboration and exactitude, as to teach us almost everything we can desire to know on this head. Hence we reproduce this description in its entirety, interspersing such extracts from the Li ki as are useful to supply its deficiencies.

«The articles of dress for the deceased are arranged in the apartments, the collars on the west side. The principal articles are placed on the south of the less important ones. The clothes are not folded. The coats and petticoats for the manes (the body clothes) are of linen (338).

These coats and petticoats are of curtain-linen; the sleeves are as wide as the breadth of the linen, and so long as to reach below the knees. The petticoat consists of a front and a back part, but it is not open at the sides ${ }^{1}$; it hangs down upon the upper part of the feet. There is a hem of a light red colour along the openings and along the lower edge, and a black hem round the neck, as also round the cuffs ( $\underline{339})$.

The pin for the hair-knot is of mulberry wood 2 ; it is four inches long and tapers away in the middle. The cowl for the head is of wellfinished taffety, as broad as a full width of cloth and five feet long; a slit is made in the lower end 3 . The ear-plugs are of fine white floss.

\footnotetext{
1 In other words, this garment was composed of two broad square pieces hanging down from the waist, the one in front and the other behind, and passing a little over each other at the sides.

2 According to the commentators this was so because the mulberry is called sang [a], which word is synonymous with another sang [b], meaning 'funeral, loss by death'.

3 On page 53 the reader will have noticed, that such a cowl is still worn by the dead at the present day. Because the $I$ li prescribes that it should be as broad as a full width of cloth, it is now-a-days called a hok kun, or 'kerchief of one width of cloth'. The Kia Ii also orders the use of it.
} 


\section{The religious system of China}

vol. I

The cover for the eyes is of black p.333 silk; it is one foot two inches square, has a red lining and strings to fasten it (behind the head) ( $\underline{340})$.

The object to be placed in the hands of the dead is of a dark stuff with a red lining. It is one foot two inches long and five inches broad. In the middle (where the hands grasp it) it is narrower by one inch on either side. A string to fasten it by is attached to it (341).

The archer's thumb-ring is of genuine royal Kih wood, or of Tseh kih wood. It is tied on by means of strings. The covers for the fingers, made of cotton floss, are two in number ${ }^{1}(\underline{342})$.

As to the corpse-sack, the sack proper is of black silk and so long as to reach to the hands. The red half, which tapers away, covers the legs (343).

In ch. 55 of the $L i k i$ (I. 25) we read :

« What is a corpse-sack ? It serves to conceal the corpse (344).

And ch. 58 of this Classic (I. 11) says :

«For the Ruler of a state the corpse-sack is embroidered; the part which tapers away is ornamented with axes, and the side is closed with strings in seven places. For a Great officer it is black, the tapering part is likewise ornamented with axe-like figures, but there are only five strings at the side. For an ordinary officer it is of dark silk; the part which tapers away is red and has three strings at the side. In general, such a sack is long enough to reach down as far as the hands, and the tapering part measures three feet $(\underline{345})$.

So the sack was not exactly p.334 a sack, as one of the sides was open and had to be tied by cords or ribbons after the body had been wrapped up in it.

The $I$ li continues its enumeration of the grave clothes as follows :

\footnotetext{
${ }^{1}$ In ancient China such covers were put on the fingers of the right hand to prevent them from being singed by the string of the bow.
} 


\section{The religious system of China}

vol. I

«The attire such as is worn with the official cap, and a dress of fine silk. The attire such as is worn with the leathern cap. A black attire with a red hem. A girdle of black silk. Knee-pads of leather. A tablet of bamboo (such as courtiers hold before their breast at audiences). Shoes of Dolichos cloth in summer, white shoes in winter, in both cases with strings between the sole and the upper leather, with strings of black silk at the points, and loops serving for button holes of the same material. On the shoes there are also ribbons and strings to fasten them at the heels. All the clothes that have been presented by the Ruler, friends and relations (see page 34 seq.) are laid out along with the rest, but are not used for dressing the dead ( $\underline{346})$.

The clothes were not put on the dead man until he had been properly washed (see page 17 seq.) and the mouth had been stuffed with cowries and rice (page 275 seq.).

«The Invoker after the manner of the Shang dynasty lays the clothes out on a couch, successively placing upon it the sacrificial garments ${ }^{1}$ and the black attire with red hemmings (347). Having placed the cowl on the head of the dead man, he puts the plugs into the ears and binds the cover before the eyes; then he puts on the shoes, knotting the strings over the top of the foot and fastening the bindings of the points. (After the dead man has been placed upon the clothes laid out on the couch just-mentioned), he dresses the body, which has three suits put on, in addition to the body clothes. He then adjusts the kneepads and the girdle, and sticks the tablet into the latter. The archer's ring is now put on p.335 the lower part of the thumb, so that it is held up by the base of the thumb ${ }^{2}$, and the object for the hands of the dead is fixed in its place by being tied to the lower parts of the

\footnotetext{
1 These garments are those mentioned above as being worn with the official cap and the leathern cap. They were called sacrificial garments because they were worn by the officials when in attendance on the Ruler while he sacrificed to his ancestors. On pp. 48 and 51 we have drawn attention to the fact that still at present notable people are very fond of having a sacrificial attire on when leaving this world, and that this is to a great extent attributable to a tendency to closely imitate the ancients.

2 In translating this passage we have followed the commentary of Ching Khang-ch'ing. But this author probably indulges in mere guess-work, the characters [] and [] being, as Ngao Ki-kung justly remarks, inexplicable.
} 


\section{The religious system of China \\ vol. I}

fingers (348). This is done in such a way, that the lining comes in contact with the skin ; the cord is wound round the middle finger and knotted on the lower parts of the fingers (녁). The corpse-sack having been laid out, the body is sheathed up in it and covered with a shroud. The cloth (which is placed over the face when the mouth is being filled with rice and cowries), the plug for the teeth, and the spoon (used for pouring in the rice), are buried in the pit (see page 16), together with the trimmings of the hair, beard and nails $(\underline{350})$, the pit being thereupon filled up by the Overseers of the waste and cultivated grounds ( $\underline{351})$.

On the next day they again arrange clothes in the apartments, the collars on the south. The principal of these articles of dress is placed on the west side of the less important. They are folded. The scarfs for winding round the corpse, three crosswise and one straight, are as broad as a whole piece and have a slit at the ends. Then follows a black sheet with a lining of a dark red colour, but without the usual hem at one end. Next comes a sacrificial attire, then the upper clothes, in all nineteen suits; subsequently they display the clothes (presented by the Ruler, friends and relations), but it is not necessary to use all these (352).

Some particulars about this display of the grave garments to be used at the slighter dressing are to be found also in the p.336 $\mathrm{Li} \mathrm{ki}$ (ch. 58, I. 1).

«As to the linen scarfs used at the slighter dressing (for swathing the dead), one is to be tied lengthwise and three crosswise. In the case of a Ruler there is one embroidered sheet, in that of a Great officer one of a plain white colour, in that of an ordinary officer one of a dark colour. There are nineteen sets of clothes. For a Ruler the clothes are displayed in the corridor on the east, for a Great officer and an ordinary officer in the apartments, all with the collars on the west and the principal article on the north side ( $\underline{353})$.

«Strong men, continues the $I$ li, having washed their hands, take up a position in pairs at the foot of the western steps, with their faces to the east. Mats are spread out in-doors (in the back chamber), one of 


\section{The religious system of China \\ vol. I}

Kien straw underneath and one of fine bamboo over it, and the Invoker after the manner of the Shang dynasty lays out over them successively the scarfs, the sheet, the upper clothes and the sacrificial garments. These (two) sacrificial garments he does not place in irregular order, but the finest he lays underneath the other. Thereupon the said strong men lift the corpse up and transfer it (to the dresses), returning then to the spot which they previously occupied (354).

«All those, says the Li ki (ch. 58, I. 8), who dress the corpse, have the upper parts of their bodies naked, but those who transfer it to the clothes are dressed. At the obsequies of a Ruler, the Great Adjuncts do the dressing, assisted by the ordinary Adjuncts ; at those of a Great officer the Great Adjuncts merely stand by, while the others do the work ; and at those of an ordinary officer the ordinary Adjuncts stand by, while the strong men perform the dressing (355).

«p.337 A couch with mats, so the I li continues, is now placed between the two pillars and covered with mats as before ${ }^{1}$. A pillow is placed on it for the head. The dressing finished, they remove the curtain. The principal mourners, their faces turned to the west, now lean on the corpse (see page 39), stamping their feet an unlimited number of times, and the female mourners, their faces turned eastward, lean on it also, acting in the same manner. The strong men then lift the corpse up ; the males and the females sustain it, and so it is carried to the hall, where (placing it on the aforesaid couch, ) they cover it with a corpse-pall (ㅌ6).

The next morning, after having extinguished the torches, they lay out the garments (for the fuller dressing) in the apartment, the collars on the south side and the principal garments on the west side of the others. They are folded up. There are scarfs for swathing the corpse, a sheet and two palls, further the grave clothes presented by the Ruler (see page 34), a sacrificial attire, upper clothes, and grave clothes presented by relations and friends, thirty suits in all, without counting the sheet. It is, however, not necessary to use them all (ㅎ57). 


\section{The religious system of China}

vol. I

« For the fuller dressing, the $L i$ ki says (ch. 58, I. 3), there are scarfs of linen, three laid straight and five laid crosswise, further, a sheet of linen and two palls ; this holds good as well for a Ruler as for a Great officer and an ordinary officer. In the case of a Ruler they display one hundred suits of clothes in the court-yard, with the collars towards the north, while the principal clothes are laid out on the west side of the others. For a Great officer there are fifty suits, displayed in the eastern corridor, the collars towards the west and the principal clothes on the south side of the others. For an ordinary officer they exhibit thirty suits in the corridor on the east, with the collars towards the p.338 west and the principal clothes on the south of the others. The scarfs and the sheet are of the same quality as the court robes. Three scarfs are cut out of one width of cloth, and they are not split at the ends. The sheet is made of five pieces of full width, and has not the usual hem at one end. $(\underline{358})$

« The hall, continues the I li, having been curtained off, the women arrange themselves on the west side of the corpse, turning their faces towards the east. The principal mourner and the near relations ascend the western steps, pass by the feet of the corpse, and stationing themselves with their faces westward, they bare the upper part of their bodies. The strong men, having washed their hands, take up a position as before ( $v i z$. as at the slighter dressing), and mats are also spread out as at the slighter dressing ( $\underline{359})$. The fuller dressing takes place near the eastern flight of steps ( $\underline{360})$.

The Invoker after the manner of the Shang dynasty successively lays out upon these mats the scarfs ${ }^{2}$, the sheet, the palls and the clothes, so that the finest of the latter shall be outermost when the corpse is dressed. The grave clothes which have been presented by the Ruler

\footnotetext{
1 That is to say, as in the case when the dead had just expired : see page 7.

2 Note that the swathing of the corpse with sheets and strips of linen, which was done twice, once at the slighter and once at the fuller dressing, is still the custom at the present day : see page 93 . No doubt this is attributable to the Kia li, which contains regulations on this head of the same tenor as those laid down in the $I \mathrm{li}$. The $\mathrm{Ta}$ Ts'ing thung li also prescribes the wrapping up in a sheet and swathing for all classes of officials and for the common people.
} 


\section{The religious system of China}

vol. I

are not placed upon one another in reverse order. Now the strong men lift the body (from the couch between the two pillars) and transfer it (to the pile of clothes). As they return to their place, the principal mourners stamp their feet an unlimited number of times. The dressing finished, they remove the curtain, and the chief mourners lean on the corpse p.339 as they did at the slighter dressing, the principal female

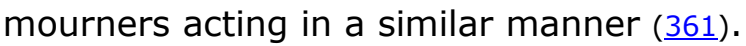

The fact that in ancient China the dead were dressed in so many expensive suits, indeed in more suits than ever living man wore, is a most convincing proof that this part of the funeral observances was the object of peculiar interest. We read in the Domestic Discourses of Confucius (see page 303) that, "when Confucius died, the clothes put on him at the first dressing consisted of eleven suits, to which was added one court dress, besides a chang-fu cap" (362), that is to say, a cap after the fashion of the Yin dynasty. Over these eleven suits the numerous attires of the slighter and the fuller dressing were put on. That the modern Chinese are still very partial to burying their dead in many suits, preferring a great number of very inferior quality to a few of good material, we have shown on page 65 ; yet the facts adduced in that part of our work prove that they are far behind their ancestors in this respect. Their imitation of the progenitors of the nation is indeed an imitation of the poorest kind. They no longer dress the dead in three different stages. The ancient first dressing they now identify with their dressing of the deceased in his body clothes after the washing (page 20); the slighter dressing of antiquity corresponds to the final dressing described on page 67 , and the fuller dressing to the coffining. This is in strict accordance with the Ta Ts'ing thung $l i$, which prescribes for all classes of officials a dressing in two stages only and calls these stages by the same names which were used by the ancients for the first and the second dressing ; the fuller dressing of antiquity is made to consist merely of the coffining. At the first dressing, it says, the official classes should have on "one suit of every day clothes, as also a court dress with cap and girdle, all corresponding to the respective ranks of each" ( $\underline{363})$; the gentry should be dressed likewise

« in one suit of every day clothes with a cap and a ceremonial attire such as corresponds p.340 with the rank of the dead ( $\underline{364})$. 


\section{The religious system of China \\ vol. I}

And as for the slighter dressing,

« the officials of the first, second and third degree are to be equipped with five suits, viz. three lined and two unlined dresses. For the officials of the fourth and fifth rank those numbers must be three, two and one, and for those of the sixth and lower ranks, two, one and one (365).

For the grave clothes of the common people the book gives no rescripts.

Returning once more to the ages prior to the Han dynasty, we find a more tangible proof than any yet mentioned, of the interest bestowed by the living upon the dressing of the dead, namely the anxiety shown by relations and friends in presenting garments for the purpose. By quoting extracts from the $I$ li we have shown on page $34 \mathrm{seq}$. that it was an established custom for all the kinsmen and friends, and in the case of an ordinary officer even for the Ruler in whose service he was, to contribute grave garments. Rulers even went so far as to send them to their princely colleagues of other feudal kingdoms.

« This was an established ceremonial usage, as the Tso ch'wen relates, The feudal princes presented to one another their condolences and congratulations, and even when the garments could not be of service (because they arrived too late), they were accepted as a mark of courtesy and recorded as such, that the good understanding which had existed heretofore between the parties, might not fall into oblivion (366).

In its $54^{\text {th }}$ chapter (I. 31) the $L i k i$ contains a detailed account of the way in which the messengers despatched by a Ruler to offer grave clothes to a mourning family acquitted themselves of their duty.

« The man with the grave clothes said: "My Ruler has sent me with clothes for the deceased". A person in attendance then entered the gate to report the arrival of the messenger and, coming out of the gate again, laid : "The orphan son So-and-so is waiting for you". Upon this the other took a dress which was worn with the crown-cap, holding the neck in his left hand and the waist in his right, and thus he 


\section{The religious system of China \\ vol. I}

entered the gate, ascended ${ }_{\text {p.341 }}$ the steps of the hall and delivered his message, saying : "My Ruler has sent me, So-and-so, with grave clothes". The son then bowed to him, touching the ground with his head and, the clothes having been laid down on the east of the spot where the body was to be stored away after the coffining, the messenger descended the steps, to receive inside the gate, under the eaves, a dress such as was usually worn with the official cap. Communicating his message in the above way, the son bowed with his forehead to the ground as before. Subsequently the messenger received in the court-yard an attire such as was worn with the skin cap ; then he received a set of court robes at the foot of the western steps, and finally, at the entrance of the hall, a dress which was worn with the dark-coloured cap; these he presented successively with the same message, the son, in each case, bowing with his forehead to the ground as he did the first time. In the end the messenger descended the steps, left the gate and returned to his place. Five men in attendance on the major domo then took up the garments and brought them to the east, afterwards going down by the steps on the west (학).

The grave clothes presented in such large quantities by anxious relations, friends and superiors were, as we have seen, displayed during the dressing. The object of this no doubt was to express the willingness of the family to make use of all of them in behalf of the dead. The question now arises : what was done with them, in so far as they were not used for dressing the corpse ? Nowhere do the ancient books clearly express themselves on this head; but considering that in ancient China it was customary to stow away in the tombs of grandees all sorts of articles, implements and valuables which might be useful to the dead, it is not beyond the bounds of probability that the clothes in question went the p.342 same way, at least in the earliest ages. This supposition assists us in explaining why the ancient works denote them by the character [], that is: clothes which follow. This character is nowhere found in the books in the sense of garments which were really used for dressing the dead, nor in that of any other sort of garments. In chapter IV of 


\section{The religious system of China}

vol. I

the next part of this Book, which is especially devoted to the custom of entombing articles with the dead, more will be said on this subject.

It is worthy of notice that the high importance which was attached in ancient China to the dressing of the dead, is testified by the fact that, in the case of grandees and their wives, the Ruler of the state and his consort attended at it personally, resorting to the house of mourning for the purpose. What the $L i k i$ and the $I l i$ say on this head has been reproduced already on page $35 \mathrm{seq}$. Besides this, the I li shows that Great officers were in the habit of displaying the same interest at the decease of ordinary officers.

«The fuller dressing, it says, takes place near the eastern flight of steps. The Great officers ascend the western steps and station themselves on the east side of the same, where they turn their faces to the north, and each higher officer stands on the east of the one of lower rank. And when the mourners have finished leaning on the corpse, the Great officers descend the steps in reverse order and return to their places (ㅎ6).

\section{Keeping the Dead unmutilated}

The belief in the resurrection of the dead having obtained such a firm hold upon the Chinese of ancient times as to prompt the creation of numerous practices for the purpose of preserving corpses from decay, it is but natural to find them also cherishing a conviction that mutilation renders a body unfit to receive the soul again. That this notion has ever been deeply rooted in their minds may be inferred from the fact that the $L i k i$ (ch. 58, I. 36) says :

«The hair and nails of the Ruler of a state and of a Great officer p.343 must be placed in the corners of his coffin, and in the case of an

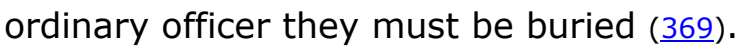

Many centuries later the Kia li prescribes that, 


\section{The religious system of China}

vol. I

« when the corpse has been lifted up with united force and placed in the coffin, the teeth and the hair which have fallen out during life are to be put in the corners, together with the parings of the nails.

And amongst its rescripts for the disposition of the dead, laid down for all classes of officials, the gentry and the common people, the Ta Ts'ing thung li likewise says, that

«the teeth and hair which have dropped out during the life of the deceased, should be placed in his coffin (370).

The authoritative rank of these works renders it very probable that the above precepts are still conformed to in many parts of the empire.

The royal house of Cheu went so far as to exclude from its grave-yards those of its blood who had died from wounds inflicted by weapons.

« Those who have been killed by arms do not enter the burial grounds, says the Cheu li (371). This passage throws a remarkable light upon the destination of those burial places. Indeed, whereas such people as by the mutilation of their bodies had lost all prospect of returning to life were not suffered therein, it is evident that at that time grave-yards were not grounds laid out by the living to dispose of useless human remains, but places where the dead were devoutly collected to await resurrection.

And, if mutilation prevents a body from ever reviving, then mangling or destroying the remains of an enemy is the most refined means of revenge. It is also the severest punishment one can inflict on the body of a criminal. The Books of the Tsin Dynasty relate that Shih Lih, a pretender to the Throne in the north eastern part of the Empire, exhumed and burned the corpse of Yueh, an imperial commander who had been in the field against him and had died in the year 311 ;

« this man, said he, has thrown the Empire into disorder, and so I must take revenge in the name of the Empire. (372)

And in the Loh-yang kia-lan ki or Description of the Buddhist Monasteries in the city of Loh-yang, a work written in the sixth century, it is related :

«In the Hiao ch'ang period (525-528) the empress confiscated Liu Thing's immovable property. The same day on which Yuen-i was killed, 


\section{The religious system of China}

vol. I

Liu Thing had already expired; but the empress remembering his crimes, she had his grave opened and his body destroyed, that his manes might be deprived of everything in which to take refuge ${ }^{1}$.

Other instances of this kind will be given in the next part of this Book, in chapter XVI, when treating of Cremation.

The idea that mangling a person after death constitutes a punishment of the severest kind, still plays an important part in the criminal legislation of modern China. The Ta Ts'ing luh li says :

«Whoever murders three members of one family, not guilty of a crime punishable with death, or whoever quarters a living person or mortally mangles him, shall be slowly cut with knives till death doth ensue. His property shall be confiscated for the benefit of the family of the victim, his wives and sons be transported for life to a country two thousand miles away, and his accomplices shall be beheaded. (푸)

Considering, however, that this cruel way of dispatching the chief culprit is too slight a punishment for so heinous a crime, a bye-law is added, to this effect :

«Moreover, his corpse shall be chopped to pieces and his head exhibited on a stake as a warning to the public.

The Legal Code has heavy punishments in store for those who p.345 mangle the dead. It even goes so far as to extend its care to criminals executed.

«Whosoever after an execution mangles or destroys the corpse shall receive fifty blows with the short bamboo stick. (374)

Further we find the following articles:

«Whoever mangles or destroys the corpse of a member of another family, or casts it into the water, shall be punished with one hundred blows with the long stick and be transported for life to a country three thousand miles distant. And he who mangles or casts away the still

$1 \mathrm{Ch}$. 3. This episode is also related, though less circumstantially, in ch. 94 of the Books of the Wei Dynasty (I. 18), and in the History of the North of the Empire, ch. 


\section{The religious system of China \\ vol. I}

unburied corpse of a kinsman who occupied a position higher than himself in the hierarchy of his family and for whom he must wear mourning in one of the five degrees ${ }^{1}$, shall be decapitated and shall be kept in jail until his sentence has been confirmed by the higher Authorities. Each of these punishments to be abated by one degree if the corpse thrown away was not lost, or when the mangling only consisted of an injury to the hair.

Whoever mangles or casts away the dead body of a kinsman who held a position in the hierarchy of the family lower than his own, and for whom the perpetrator would have to wear mourning in one of the five degrees, shall undergo a punishment similar to that inflicted when the corpse of any one belonging to another family is concerned, but with a mitigation by one degree for each degree of relationship by which the perpetrator stands above the dead.

Mangling or throwing away the corpse of a son or grandson shall be punished with eighty blows with the long stick. But any child or grandchild who commits the same offence against a grandfather, grandmother, father or mother, or any male or female slave or hireling who mangles or throws away the body of his master, shall be beheaded and shall be kept in jail until p.346 his sentence has been confirmed by the higher Authorities, no account being taken as to whether the body was destroyed or lost. $(\underline{375})$

The significance of these provisions of law will be better understood, if we take into consideration that the Code is hardly less severe with regard to the crimes these articles are intended to prevent, than on the point of wilful murder. Premeditated murder of a person not belonging to the family of the perpetrator is punished with decapitation, which is a penalty only two degrees more severe than that inflicted for the mutilation of the corpse of such an individual, or for the making away with it. Further, for parricide or the murder of a grandparent or great-grandparent, slow execution by the knives is decreed, which punishment is only one degree heavier than decapitation, with

92, I. 17.

${ }^{1}$ About these degrees see ch. VI of the next part of this Book. 


\section{The religious system of China}

vol. I

which persons who have mangled or thrown away the corpse of such a relative must expiate their crime.

In chapter XI of the next part of this Book we shall revert at length to the protection awarded to the bodies of the dead by the State, whose line of conduct on this head is the natural outgrowth of the great political principle that the Religion of the Dead must be maintained by all possible means. This primary religion of China, sanctified by the books of Confucius and his school, is enforced upon the nation by the present dynasty as the most holy institution of social life, being closely connected with the doctrines of the hiao referred to on page 120 . In connection with this political principle successive dynasties have promulgated codifications of the funeral rites, such as the reader has been acquainted with on page 236.

The inveterate aversion of the Chinese of all ages to the mutilation of the body after death explains why in the Ta Ts'ing luh li decapitation is considered a punishment of a severer nature than strangulation. Both methods of despatching criminals are ranked by that Code side by side as the 'severest penalty existing'; but at the same time it makes a distinction between the two because, as it says, "strangulation leaves the body entire in p.347 all its parts", while "decapitation sends the body and the head to different places" (376). It is, indeed, entirely in accordance with this legal distinction that the heads of criminals executed in the province, when not exposed on stakes or in cages as a warning to the public, are in many instances sent up to the provincial capital, to serve not only as warrants to the higher authorities that the execution has taken place, but also to make sure of their not being buried along with the body. 


\section{CHAPTER VI}

\section{On the cohabitation of the soul and the body after death}

p.348 The belief in the resurrection of the dead has waned away in the process of time. As civilization advanced, cold experience taught the sons of the Empire of the Midst that death was real. Nevertheless, as this Volume testifies on many of its pages, numerous practices created by the said belief have survived. Nor has the conviction been lost that the manes continue to hover about the body and to be intimately connected with it, a conviction naturally arising from the old belief that they might at a suitable moment again enter the corpse and resuscitate it.

That such a belief in the cohabitation of the body and the soul really exists among the modern Chinese as vividly as ever, is shown by many of their funeral customs. We need only draw attention to those enumerated on page 241. Amongst them is that of systematically entombing part of the manes with the corpse by placing the soul banner and the temporary soul tablet in the grave with the coffin. This custom is of special importance, because it introduces us to a new series of practices and conceptions relative to the tomb and the treatment of the body and the soul which dwell therein, practices and conceptions so numerous, that a description of them will occupy almost the whole of the next volume and a great part of the Second Book. By the way it may be noted that the ideas about such cohabitation of body and soul in the grave are closely connected with the conception that, if a body is properly circumvested by objects and wood imbued with Yang matter or, in other words, with the same shen afflatus of which the soul is composed, it will be a seat for the manes even after death, a support to which the manes may firmly adhere and thus prevent their nebulous, shadowy being from evaporating and suffering annihilation. Coffins with a corpse inside are, in accordance with this notion, designated throughout the whole p.349 range of Chinese literature as 'animated encoffined corpses', or 'animated coffins'. 


\section{The religious system of China \\ vol. I}

The conception that after death the body and the soul do not separate for good, having given rise to a category of practices so comprehensive that a great part of this work will have to be devoted to them, it becomes our duty to prove by facts that such a conception has always been a predominant article in the creed of the nation. Passages quoted from native books for this purpose will at the same time acquaint our readers with some matters of interest relative to the Religion of the Dead, which could not be elsewhere better inserted.

It is related in the historical documents of the Empire that Wu Tszĕ-sü, a minister of the kingdom of Wu in the sixth century before our era, having at the head of an army conquered the town of Ying, he there exhumed the body of P'ing, a former king of the state of Ch'u, and had it flogged, as a retaliation for the execution of his father who, when a minister in Ch'u, had been put to death by P'ing. The Historical Records say :

«When the troops of Wu entered Ying, Wu Tszĕ-sü tried to lay hands on king Chao (P'ing's successor) ; but being unable to discover him, he opened the grave of king P'ing of Ch'u, dragged his corpse out of it and gave it three hundred lashes. (377)

This act would have been perfectly devoid of sense if Wu Tszĕ-sü had not been firmly convinced that, when flagellating a corpse, something more than a lifeless lump of flesh and bones was struck at.

In chapter 26 of the Li ki (leaf 1 sqq.) we read :

« Tseng-tszĕ asked : "When a successor to the Throne is born after the demise of the Ruler of the state, how is one to act ?"

Confucius said: "The highest nobles, Great officers and ordinary officers shall take a position behind the minister who administers the State ad interim, at the south side of the western steps, turning their faces to the north. The Great Invoker, in his court robes and cap, bearing rolls of silk in his hands, shall then go up to the top of the western steps, and there, without entering the hall, he shall, when the wailers have been ordered to stop their cries, call three times (to the soul) and make announcement p.350 to it, saying : "The son of Such- 


\section{The religious system of China}

vol. I

and-such a lady has been born; I presume to inform Thee of this event". This done, he shall enter the hall, lay the silk on a bench on the east side of the place where the coffin is, wail and descend. All the principal mourners, the high nobles, Great officers and ordinary officers, with all those who find themselves in the apartments, shall wail also, but without stamping their feet. This burst of grief over, they shall return to their assigned places, after which the morning offerings (see page 118) shall be set out and the Second Minister shall go up the steps and take the silks away.

And on the third day, all the principal mourners with the high nobles, Great officers and ordinary officers shall take their places as before, with their faces towards the north. The First Minister, the Superintendent of Religious Worship and the Great Invoker shall all be dressed in their court robes and cap, and the officer in charge of the education of the child shall carry the babe in his hands in a coat of sackcloth. When they enter the gate, the Invoker preceding, the child behind him, and the First Minister with the Superintendent of Religious Worship in the rear, the wailers put a stop to their lamentations; the child is then brought up by the western steps and held in front of the place where the coffin stands, with his face to the north, while the Invoker stations himself at the south-eastern corner of the coffin. Now the Invoker shall call three times (to the soul) and exclaim : "So-andso, the son of Such-and-such a lady, presumes to appear before Thee, under the guidance of those in charge of the ceremony". The babe shall then bow his forehead to the ground and wail. The Invoker, the First Minister and the Superintendent of Religious Worship, with the principal mourners, the noblemen, Great officers and ordinary officers now wail and stamp their feet three times, repeating three testimonies of grief p.351 twice; this done, they descend the steps and return to their proper places on the east, where all of them bare the upper parts of their bodies. Now the child shall stamp his feet, and the persons in the apartments shall act likewise ; thrice they shall do so, stamping three times each time. Having dressed the child with the coat of sackcloth and given him a mourning staff in his hand, the (morning) 


\section{The religious system of China}

vol. I

offerings to the deceased are set out, after which they leave the gate. The First Minister shall also give orders to the Invoker and the Recorder to announce the name of the child all around at the five places of sacrifice and at those devoted to the hills and streams. (궁)

Such announcements, first made to the dead monarch of the birth of his heir and afterwards of the name which had been given him, evidently ranked among the principal solemnities of the State, seeing that they were presided over by the highest ministers and that the high nobility, the gentry and the whole host of officials attended them. If Confucius had not been absolutely under the sway of the dogma of his time that the soul remains present at the side of the body of which it once constituted the vital energy, he would never have sanctioned such announcements as matters of State, as observances which no government might presume to neglect. Could China's greatest philosopher have prescribed the celebration of such an ostentatious ceremony to a mass of mere lifeless clay ? Many passages might be quoted from the Li Ki and other ancient works to illustrate the ancient belief in an intimate coherence of the corpse and the soul. But this would only weary the reader ; moreover, it is quite superfluous in the face of the above citations, which speak volumes.

In perusing such of the interesting pages of the Historical Books of p.352 the Han dynasty as describe the ceremonial institutions of the State at that time, we find that the inveterate belief in the presence of the disembodied soul about the corpse had already then prompted the Government to celebrate another solemnity of the first order, viz. the succession to the Throne, in the immediate presence of the deceased monarch.

«After the demise, the gates of the city and of the palace were closed. The Ministers surrounding the Throne, the Commanders of the soldiers of the interior yellow gates, the Imperial body guards and the Secretaries of the Boards all kept a vigilant watch at the palace buildings, each exhorting five pickets of the northern division of the army to surround the palace, while eunuchs from amongst the farming soldiery ordered the ushers of the Presidents of the Boards and those of the Censors to patrol the files of warriors during the day and the 


\section{The religious system of China}

vol. I

night ${ }^{1}$. The three Chief Ministers of State presented a memorial to the Throne, running as follows. "If, as the Shu king expresses it, the commandments of Heaven are kept in sight ${ }^{2}$, the Crown prince must mount the throne of the Son of Heaven on the same day, in front of the encoffined body. Accordingly we beseech the Crown prince to take possession of the Imperial throne, and the Imperial Consort to become Imperial Grand Consort ${ }^{3}$. This request having been answered in an approving sense, all the ministers left and then re-entered without mourning clothes, to assemble (in the court-yard) in conformity with the prescribed ritual.

The Commander of the Army then ascended the eastern steps. Stationing himself with his face to the north near the coffin and the Imperial throne, he bowed his head to the ground, recited an address and then, facing the east and in a kneeling attitude, p.353 tendered to the Crown prince the seals of jade with the ribbons appended, which usually did service in transferring the Realm from one emperor to another. This done, the Crown prince ascended the Imperial throne. The Commanders of the inner yellow gates then handed to the Commander of the Army the articles of jade, the Sui-heu pearls ${ }^{4}$ and the serpent-beheading precious sword; what had happened was thereupon solemnly announced to the multitude of officers present, and all prostrated themselves, exclaiming : "May Your Majesty reign ten thousand years !" In some cases a general amnesty for the Empire

\footnotetext{
1 It may be asked whether these measures were taken to prevent the soul of the deceased from escaping, and thus to facilitate the task of those who had to bring it back (comp. p. 251). It is otherwise difficult to account for them.

2 This expression occurs in the section Thai-kiah of that Classic, in a memorial presented to the young monarch Thai-kiah $\left(18^{\text {th }}\right.$ cent. B. C. $)$ by his Counsellor I-yin. The memorial opens with the words : "The sovereigns who have preceded Thee on the throne, kept their eyes on the clear commandments of Heaven".

3 In China the position of an Empress-Dowager is higher than that of an Empress because, during the reign of her son, she is the owner of the empire, "a son having no property of his own as long as his father or mother lives" (Li ki, Ch. 2, I. 21). But an Empress whose husband is living cannot possess the empire, because it belongs to her consort.

4 Precious pearls shining during the night (see page 277) are often denoted by this name on account of a legend told of one Sui-heu, who had once upon a time received a pearl which could light up an entire room at night, from a wounded snake he had cured. See the Pei wen yun fu, ch. 26 II, I. 94.
} 


\section{The religious system of China \\ vol. I}

was at the same time proclaimed. Messengers were dispatched with orders from the Emperor to re-open the gates of the city and the palace, and to march off the farming soldiers and other guards; all the ministers and officers then retired, and put on such complete mourning attire as was prescribed by the established rites. (379)

Nearly all the monarchs who have borne sway over the Empire from the seventh century to the fourteenth, including those of the Liao dynasty, are formally stated in the official books of history to have ascended the throne in the presence of their encoffined predecessor. Though such statements are not made with similar regularity with regard to the other dynasties, yet there seems to exist little ground for doubting that these also faithfully conformed p. 354 to what the House of Han had established as an institution of the State. As for the dynasty which now wields the sceptre, - according to the Ta Ts'ing thung li, the accession to the Throne is celebrated in the Thai-hwo hall on the second day after the deceased monarch has been dressed and coffined, but the work does not state whether the coffin is in the hall on this occasion.

«The Imperial heir repairs to the sacrificial tables which are placed in front of the coffin, there to invoke the deceased parent and announce to him that he accepts the task imposed upon him by Heaven; after having left he puts on his ceremonial attire and goes to the Thai-hwo hall, to ascend the Imperial throne. (380)

These official rescripts sufficiently prove that the belief in the presence of the soul on the spot where the coffin is deposed, is still entertained by the present emperors.

Chinese literature affords numerous proofs that the cohabitation of soul and body after death has never been doubted in succeeding ages. To quote one single instance out of the many before us : - the History of the South relates of Wang King-tsih, a statesman living in the last half of the fifth century :

« On reaching the district city of Ki-yang (where he was to enter upon his functions as Governor), at the foot of the Luh-chu mountains the ten and odd chips of his clans-people who accompanied him started, but his own boat was the only one which did not move. He ordered his 


\section{The religious system of China \\ vol. I}

junior relations to jump into the water and push it forward, when his eye fell upon some black-varnished coffins. Invoking these, he said : "If you are objects of good omen, then cause my boat to move forward quickly; and as I am a wealthy man occupying a high position, I will take care that you are properly buried". Instantly the boat moved on unto the city. Afterwards he had the coffins collected and buried. (381)

p.355 It is quite natural man should imagine that the souls of the dead retain the shape of the body which they possessed during life. This must be true of the Chinese in particular, seeing they are convinced that body and soul keep together after death, a conviction which calls up the body immediately before their eyes whenever they think of the soul. They believe that a beheaded man wanders about a headless spectre in the World of Shades. Such spectres are frequently to be seen in walled towns, especially in the neighbourhood of places of execution. Here they often visit the people with disease and disaster, causing a considerable depreciation in the value of the houses around such scenes. Whenever an execution takes place, the people fire crackers to frighten the headless ghost away from the spot; and the mandarin who has superintended the bloody work, on entering the gate of his mansion, has himself carried in his sedan chair over a fire lighted on the pavement, lest the headless apparition should enter there along with him ; for disembodied spirits are afraid of fire. On August $22^{\text {nd }} 1849$ the Governor of Macao having been assassinated near the Barrier by some Chinese, who severed his head from his body and fled on Chinese soil with this bloody testimony of the murder, the native inhabitants of the port declared that the spectre was often seen riding up and down the isthmus, looking for his head ; and these rumours inspired such terror, that no one dared go home through the Barrier after nightfall (382). In the 'Celestial Empire' of February $7^{\text {th }} 1883$ (page 78) we read :

« The Chinese have a theory that a headless corpse in this world wanders about a headless ghost in the next, and they adopt the subterfuge of fixing a wooden head to a corpse, thinking thereby that the spirits will not know the difference. A case of this kind has lately occurred. It will be remembered that the head of the mandarin who 


\section{The religious system of China}

vol. I

was murdered in Quangse Road (Shanghai), could not be found, Search was made for it without success, so the compradore, who was a friend of the deceased, has had a wooden head made and placed in the coffin with the body of the murdered man. This having been done, the corpses of the mandarin and his wife were removed from Quangse Road for burial. 


\section{The religious system of China \\ vol. I}

\section{CHAPTER VII}

\section{Placing food in the mouth and by the side of the deceased}

p.356 The conception that death is a state of insensibility from which the body may awake as well as from sleep or a swoon (comp. page 244), naturally induced primitive man, on seeing that the unconsciousness of the patient lasted uncommonly long, to place food at his side and, finding that he did not partake of it, to try to make him eat by putting morsels into his mouth. These practices are still prevalent among many tribes. In the Far East may be instanced the Assu Islanders,

« of whom Earl says that several times during the few days after one has died, these Papuans try to make him eat, 'and when they find that he does not partake of the food, the mouth is filled with eatables, siri, and arrack, until it runs down the body, and spreads over the floor'. Among the Tahitians, 'if the deceased was a chief of rank or fame, a priest or other person was appointed to attend the corpse, and present food to its mouth at different periods of the day'. So is it with the Malayans of Borneo: when a chief dies, his slaves attend to his imagined wants with the fan, siri, and betel-nut. Harkness tells us of the Badagas, that 'between death and burning they frequently drop a

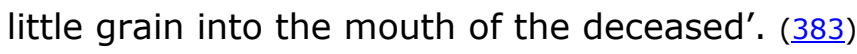

The like remarkable customs were observed by the Chinese in times of old. Confucius himself was convinced that, like the calling back of the soul, these customs had originated in the darkest ages; for, according to the $\mathrm{Li}$ ki (ch. 30, I. 20), he said :

«When ceremonial usages came into existence, people, whenever a case of death occurred, went up to the housetop and exclaimed : "Ho. o. o. So-and-so, come back !" After this they filled the mouth with uncooked rice and put cooked food upon stands. (384) 


\section{The religious system of China}

vol. I

At the p.357 time of the Cheu dynasty we find that such stuffing of the mouth was considered a rite of so much importance that it had a place allotted to it among those funeral observances which no one might neglect. This may be inferred from the following passage in the $L i k i$ (ch. 11, I. 37) :

«Calling back the soul, plugging open the teeth, binding the legs on a seat to keep them straight, filling the mouth with rice, laying out the clothes for the dead, and curtaining the hall - these things are performed conjointly. (385)

According to the unanimous assertion of commentators, this plugging open the teeth served to prevent the mouth from closing tightly when the body grew cold, which would have rendered the stuffing very difficult; therefore it was done almost immediately after the last breath had escaped from the lips of the dying man. After describing the way in which the soul of a deceased officer was called back (see page 248), the I li says :

« They plug the teeth open with a spoon of horn and tie the legs to keep them from contracting, using a seat to this end. (386)

And the Li ki (ch. 57, I. 34) has :

«As soon as death has taken place, the corpse is transferred to a couch and covered with the same shroud which is to be used at the dressing. The garments in which the dead man has expired are then taken off, a lower official plugs the teeth open with a spoon of horn, and the feet are tied straight by means of a stool. All these things are done in the case of a Ruler as well as in that of a Great officer and an ordinary officer. (387)

The clear and elaborate description which the $I$ li gives of the way in which the stuffing of the mouth was performed in the case of ordinary officials, has been reproduced in full in the chapter dealing with the placing of precious articles in the mouth of the dead, so that we have only to refer the reader to page 276. It must be noted by the way, that the importance attached to the rite in question during the Cheu dynasty is manifest also from the fact that the Cheu li is not silent on it, as may be seen on pages 20 and 269, where two extracts from this book alluding to the same subject have been inserted. 


\section{The religious system of China}

vol. I

p.358 Such of our readers as have studied the written language of China may see from the passages quoted in this chapter, that the practice of stuffing the mouth of the dead is denoted in the Li ki and the Cheu li by the character []. This occurs in all the works of antiquity in the sense of 'a meal, or to take a meal', as its composition from the elements [], 'to come back', and [], 'to eat', implies; which clearly shows that the stuffing of the mouth was indeed conceived of by the people as a feeding process. Nevertheless one passage in the $L i k i$ (ch, 12, I. 22) points to the contrary, saying :

« The mouth is filled with uncooked rice and with cowries because one cannot bear the idea that it should be empty; the underlying idea in using these good things is not that of giving food. (388)

But we cannot help repudiating this view, on ethnographical grounds. Even during the Han dynasty the true purport of the custom was not lost sight of, as the Poh hu thung $i$, a work of the first century to which we have already referred on page 277 , says :

«Wherefore exists this custom of filling the mouth of the dead with rice ? It is a continuation of the feeding of the living. (389)

During the Han dynasty the custom likewise held a place among the funeral rites for monarchs and grandees, as may be seen from two extracts reproduced on page 277 . It was allotted a place in the Codex of Rites of the Khai yuen period, which orders that

« for grandees of the highest, the second and the third degree spiked millet shall be used, for those of the fourth and fifth rank panicled millet, and for all persons of still lower rank spiked millet.

Uncooked rice, well cleansed, must, according to Chu Hi's Rituals for Family Life, be poured into the mouth of the dead by the principal mourner when he places the coins therein (see page 278), all this to be done with observance of the ceremonial prescribed by the I li ; but the Ta Ts'ing thung li gives no rescripts about the practice. This explains in some measure why the custom has now fallen into disuse at Amoy and its environs (see page 29), so that, in describing the modern funeral rites, we have not mentioned p.359 it. But we do not suppose it has died out all over China, the influence of the ancient 


\section{The religious system of China}

vol. I

works and the Rituals for Family Life being too great to justify such a supposition.

Placing food at the side of the corpse, which may be said to be simply another form of the custom of actually feeding it by filling its mouth, is, however, far from having gone out at Amoy. This we have shown on page 29, in describing the way in which it is done there at the present time. Considering, as we have said at the outset of this chapter, that the same practice prevails elsewhere on the globe among tribes in a low stage of civilization, it is not surprising that it should have been an established custom in barbarous and semi-civilized China, and as such held the rank of a sacred funeral rite in the Empire during the pre-Christian era. Chapter 13 of the $L i k i$ (leaf 11 ) says :

«Presently after the demise dried meat and pickled meat are set down. (390)

And the $I$ li, immediately after giving rescripts as to the calling back of the soul, plugging open the mouth and tying the legs to a stool, says :

«They set down dried meat, pickled meat, must and wine. These articles having been taken up the eastern steps, they are deposed on the east side of the corpse (391). They are set down near the couch, close to the shoulder. No funereal vessels are employed. Either must is offered, or spirits, but no covers of cloth are used, nor spoons. (392)

The I li thus explicitly forbidding the food to be placed in such vessels as were used for the service of the dead, we are justified in suggesting that the patient was not considered dead in reality, but only in appearance. It is also noteworthy that Ngao Ki-kung says in his commentary upon the above passage :

« Those articles were set down after the demise as if a living person were being waited upon. The dead man was now lying with his head southward, so that the east was on his right hand, and the articles were placed on this side to enable him to partake more easily of the food and the drink. 


\section{The religious system of China}

vol. I

p.360 The ancient Chinese did by no means confine themselves to placing food at the side of the dead only once. They also supplied a sumptuous meal the next day, after the dead man was dressed for the grave. The elaborate description given by the $I$ li of this sacrifice has been inserted in full on page 83 sqq. As has been shown on page 70 sqq., the modern Chinese still faithfully maintain this usage. Neither do they, as we have seen on page 99, deviate from the ways of their ancestors in placing food near the corpse after it has been enclosed in the coffin, for in ancient China too the nobility and gentry went so far as to continue the process of feeding after the coffining, by placing baskets with scorched grain and dried fish and meat inside the wooden shed in which the body was stored away in the hall of the mansion. This custom, which was cursorily touched upon on page 99, is more particularly passed in review in the first chapter of the third part of this Book. If we now call to mind the rooted belief of the Chinese of all ages that the soul does not abandon the body after death, it appears quite natural the conviction arose at a very early date that it is the soul which enjoys the food, as nobody ever saw the body touch it. The numerous presentations of edibles and liquors to the dead body even after it has been nailed up in an enclosure of six substantial planks, are in this way easily accounted for. Some of these sacrifices have been described in both their ancient and modern shape in our dissertation on Funeral Rites. Many more, not mentioned therein, are presented after the interment at regular intervals for years, nay in many cases for ages; these will form part of the subject of our Second Book, which is specially devoted to the Soul and its Worship. 


\section{The religious system of China}

vol. I

\section{N O T E S}

1.(101) [Trad. Legge, Bk I, I, 5 ; cf. Li ki, trad. Couvreur, t. I, p. 53].

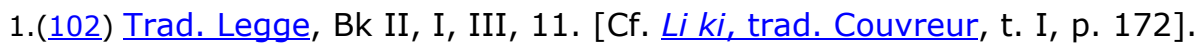

1.(103) All this, except the second sentence, is also to be found in ch. 57 of the $\mathrm{Li} \mathrm{ki}$,

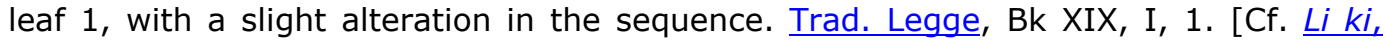
trad. Couvreur, t. II, p. 202].

1.(104) Trad. Legge, Bk II, I, III, 18. [Cf. Li ki, trad. Couvreur, t. I, p. 175].

1.(105) Trad. Legge, Bk II, I, I, 18. [Cf. Li ki, trad. Couvreur, t. I, p. 126]

1.(106) [Trad. Legge, Bk XIX, I, 5 ; cf. Li ki, trad. Couvreur, t. II, p. 206].

1.(107) Chapter 26, I. 34 and 35.

1.(108) Chapter 27, I. 1 and 2.

1.(109) Chapter 31, I. 12.

1.(110) Chapter 27, I. $2-5$.

1.(111) Chapter 31, I. 13.

1.(112) Chapter 27, I. 6 and 7.

1.(113) Chapter 19, I. 21. [Cf. Tcheou-li, trad. Biot, t. I, p. 451].

1.(114) Chapter 19, I. 35. [Cf. Tcheou-li, trad. Biot, t. I, p. 458].

1.(115) Chapter 20, I. 9. [Cf. Tcheou-li, trad. Biot, t. I, p. 470].

1.(116) Chapter 25, I. 14. [Cf. Tcheou-li, trad. Biot, t. II, p. 91].

1.(117) Chapter 25, I. 22. [Cf. Tcheou-li, trad. Biot, t. II, p. 96].

1.(118) [Trad. Legge, Bk XIX, I, 23 ; cf. Li ki, trad. Couvreur, t. II, p. 218]

1.(119) [Trad. Legge, Bk XIX, I, 15 ; cf. Li ki, trad. Couvreur, t. II, p. 213].

1.(120) Chapter 28, I. 1.

1.(121) Spencer. The principles of Sociology, § 108.

1.(122) Trad. Legge, Bk II, I, II, 28 [Cf. Li ki, trad. Couvreur, t. I, p. 151].

1.(123) Chapter 26, I. 23 sqq. [Cf. I li, trad. Couvreur, p. 441-442].

1.(124) Chapter 26, I. 27 seq. [Cf. I li, trad. Couvreur, p. 442].

1.(125) Chapter 26, I. 30 seq.

1.(126) Chapter 28, I. 24 - 34. [Cf. I li, trad. Couvreur, p. 465 sqq].

1.(127) [Trad. Legge, Bk XIX, II, 15 ; cf. Li ki, trad. Couvreur, t. II, p. 236].

1.(128) [Cf. Tcheou-li, trad. Biot, t. II, p. 98 ; Tcheou-li, trad. Biot, t. II, p. 103].

1.(129) [Cf. Tso tchouan, trad. Couvreur, t. III, p. 520]. This episode is related also, though in very obscure terms, in ch. 13 of the Li ki, leaf 43 (section T'an koung, II, 2).

1.(130) Trad. Legge, Bk III, V, 4 [Cf. Li ki, trad. Couvreur, t. I, p. 314]. The same passage occurs also in ch. 40, I. 1 [Trad. Legge, Bk X, II, 1 ; cf. Li ki, trad. Couvreur, t. I, p. 649]

1.(131) Trad. Legge, Bk I, II, III, 2 [Cf. Li ki, trad. Couvreur, t. I, p. 97].

1.(132) Comp. The great thesaurus Ku kin thu shu tsih ch'ing, section [][], chap. 148. 


\section{The religious system of China}

vol. I

1.(133) Ku kin thu shu tsih ch'ing, same section, chap. 148.

1.(134) Chapter 27, I. 29 and 30.

1.(135) Chapter 27, I. 35.

1.(136) Chapter 27, I. 49 and 50.

1.(137) Chapter 27, I. 50 and 51.

1. (138) Chapter 27, I. 51.

1.(139) Chapter 27, I. 52 and 53.

1.(140) The social life of the Chinese, ch. VI.

1.(141) Trad. Legge, Bk II, I, III, 36 [Cf. Li ki, trad. Couvreur, t. I, p. 182 (§ 36)].

1.(142) Trad. Legge, Bk X, I, 4 [Cf. Li ki, trad. Couvreur, t. I, p. 623].

1.(143) Chung yung or 'Doctrine of the mean', XIX. [Cf. trad. Couvreur].

1.(144) China, ch. XII.

1.(145) Gray, China, ch. XII.

1.(146) The social life of the Chinese, ch. VII.

1.(147) Chapter 22, I. 39 seq. [Cf. Tcheou-li, trad. Biot, t. II, p. 40].

1.(148) Chapter 22, I. 51. [Cf. Tcheou-li, trad. Biot, t. II, p. 45].

1.(149) Chapter 23, I. 21. [Cf. Tcheou-li, trad. Biot, t. II, p. 51].

1.(150) Chapter 23, I. 29. [Cf. Tcheou-li, trad. Biot, t. II, p. 55].

1.(151) Chapter 23, I. 45. [Cf. Tcheou-li, trad. Biot, t. II, p. 61].

1.(152) Chapter 23, I. 48 and 51. [Cf. Tcheou-li, trad. Biot, t. II, p. 63].

1.(153) Chapter 23, I. 57. [Cf. Tcheou-li, trad. Biot, t. II, p. 67].

1.(154) The social life of the Chinese, ch. VII.

1.(155) Chapter 31, I. 27. [Cf. Tcheou-li, trad. Biot, t. II, p. 225].

1.(156) Chapter 16, I. 4.

1.(157) [Cf. I li, trad. Couvreur, ch. 17, p. 488].

1.(158) [Trad. Legge, Bk XV, II, 6 ; cf. Li ki, trad. Couvreur, t. II, p. 3].

1.(159) [Trad. Legge, Bk XVIII, I, II, 33 ; cf.Li ki, trad. Couvreur, t. II, p. 148].

1.(160) $23^{\text {rd }}$ Year of the ruler Ngai. [Cf. Tso tchouan, trad. Couvreur, t. III, p. 749].

1.(161) Trad. Legge, Bk II, I, II, 9 [Cf. Li ki, trad. Couvreur, t. I, p. 136].

1.(162) Trad. Legge, Bk II, I, II, 16 [Cf. Li ki, trad. Couvreur, t. I, p. 141].

1.(163) Chapter 29, I. 7 and 9.

1.(164) Chapter 30, I. 32.

1.(165) [Trad. Legge, Bk XIX, II, 37 ; cf.Li ki, trad. Couvreur, t. II, p. 252].

1.(166) [Trad. Legge, Bk XIX, II, 37 ; cf.Li ki, trad. Couvreur, t. II, p. 252].

1.(167) The Khienlung edition of the Li ki, ch. 58, I. 40.

1.(168) Chapter 7, I. 49. [Cf. Tcheou-li, trad. Biot, t. I, p. 166].

1.(169) Chapter 7, I. 31. [Cf. Tcheou-li, trad. Biot, t. I, p. 157]. 


\section{The religious system of China}

vol. I

1.(170) [Trad. Legge, Bk XVIII, IV, 16 ; cf. Li ki, trad. Couvreur, t. II, p. 186].

1.(171) Chapter 20, I. 15.

1.(172) [Trad. Legge, Bk II, II, I, 10 ; cf. Li ki, trad. Couvreur, t. II, p. 186].

1.(173) Chapter 30, I. 41.

1.(174) [Trad. Legge, Bk XVIII, II, I, 35 ; cf. Li ki, trad. Couvreur, t. II, p. 174].

1.(175) Chapter 11, I. 28. [Cf. Tcheou-li, trad. Biot, t. I, p. 256].

1.(176) Chapter 30, I. 37 sqq.

1.(177) [Trad. Legge, Bk II, II, II, 5 ; cf. Li ki, trad. Couvreur, t. I, p. 214].

1.(178) Ku kin thu shu tsih ch'ing, chapter 55, I. 1.

1.(179) Chapter 30, I. 26.

1.(180) Chapter 31, I. 45.

1.(181) Chapter 30, I. 40.

1.(182) [Trad. Legge, Bk II, II, II, 4 ; cf. Li ki, trad. Couvreur, t. I, p. 213].

1.(183) [Trad. Legge, Bk XVIII, I, II, 9 ; cf. Li ki, trad. Couvreur, t. II, p. 135].

1.(184) See the $P^{\prime} i$ ya, composed by Luh Tien, ch. 6.

1.(185) Koh chi king yuen, Mirror and Source of thorough Investigation, ch. 80, I. 10.

1.(186) Pen-ts'ao kang muh, chapter 48.

1.(187) [Trad. Legge, Bk V, I, 6 ; cf. Li ki, trad. Couvreur, t. I, p. 417].

1.(188) [Trad. Legge, XVIII, II, I, 13 ; cf. Li ki, trad. Couvreur, t. II, p. 162].

1.(189) Chapter 30, I. 37.

1.(190) [Trad. Legge, Bk V, I, 6 ; cf. Li ki, trad. Couvreur, t. I, p. 206].

1.(191) [Trad. Legge, Bk XVIII, I, II, 19 ; cf. Li ki, trad. Couvreur, t. II, p. 139].

1.(192) [Trad. Legge, Bk II, II, II, 22 ; cf. Li ki, trad. Couvreur, t. I, p. 233].

1.(193) Khienlung edition of the $I l i$, chapter 26, I. 12.

1.(194) [Trad. Legge, Bk VII, I, 7 ; cf. Li ki, trad. Couvreur, t. I, p. 503].

1.(195) [Trad. Legge, Bk XIX, I, 3 ; cf. Li ki, trad. Couvreur, t. II, p. 205].

1.(196) Sect. K'iu li, II, 1.

1.(197) [Trad. Legge, Bk I, II, II, 15 ; cf. Li ki, trad. Couvreur, t. I, p. 93].

1.(198) [Trad. Legge, Bk XIII, II, 7 ; cf. Li ki, trad. Couvreur, t. I, p. 756].

1.(199) [Trad. Legge, Bk XVIII, I, I, 16-18 ; cf. Li ki, trad. Couvreur, t. II, p. 124].

1.(200) Khienlung edition of the $I l i$, chapter 26, I. 5 .

1.(201) Chapter 26, I. 5 and 9.

1.(202) Chapter 26, I. 9 sqq.

1.(203) Li ki, ch. 57, I. 8.

1.(204) [Trad. Legge, Bk II, II, I, 22 ; cf. Li ki, trad. Couvreur, t. I, p. 199].

1.(205) Sect. Tsa ki, I, 1.

1.(206) Trad. Legge, Bk XVIII, I, II, 24 [Cf. Li ki, trad. Couvreur, t. II, p. 141]. 


\section{The religious system of China}

vol. I

1.(207) [Trad. Legge, Bk V, II, 23 ; cf. Li ki, trad. Couvreur, t. I, p. 207].

1.(208) [Trad. Legge, Bk XVIII, I, I, 1 ; cf. Li ki, trad. Couvreur, t. II, p. 115].

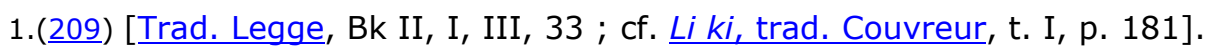

1.(210) Chapter 7, I. 59 seq. [Cf. Tcheou-li, trad. Biot, t. I, p. 170].

1.(211) Chapter 31, I. 39. [Cf. Tcheou-li, trad. Biot, t. II, p. 231].

1.(212) Chapter 31, I. 44. [Cf. Tcheou-li, trad. Biot, t. II, p. 234].

1.(213) [Trad. Legge, Bk II, I, I, 20 ; cf. Li ki, trad. Couvreur, t. I, p. 127].

1.(214) Ku kin thu shu tsih ch'ing.

1.(215) See the editions of the Kia li.

1.(216) [Trad. Legge, Bk II, I, I, 14 ; cf. Li ki, trad. Couvreur, t. I, p. 120].

1.(217) [Trad. Legge, Bk VI, II, 16].

1.(218) [Trad. Legge, Bk II, I, II, 10 ; cf. Li ki, trad. Couvreur, t. I, p. 137].

1.(219) Sect. T'an koung, II, 2.

1.(220) [Trad. Legge, XXXI, 22 ; cf. Li ki, trad. Couvreur, t. II, p. 548].

1.(221) [Trad. Legge, Bk II, I, I, 8 ; cf. Li ki, trad. Couvreur, t. I, p. 116].

1.(222) [Trad. Legge, Bk II, I, I, 28 ; cf. Li ki, trad. Couvreur, t. I, p. 131].

1.(223) [Trad. Legge, Bk II, I, II, 14 ; cf. Li ki, trad. Couvreur, t. I, p. 140].

1.(224) [Trad. Legge, Bk II, I, II, 37 ; cf. Li ki, trad. Couvreur, t. I, p. 159].

1.(225) [Trad. Legge, Bk II, I, II, 27 ; cf. Li ki, trad. Couvreur, t. I, p. 149].

1.(226) Sect. Ouen sang.

1.(227) Chapter 19, I. 35. [Cf. Tcheou-li, trad. Biot, t. I, p. 459].

1.(228) Chapter 24, I. 4.

1.(229) Sect. T'an koung, II, 1.

1.(230) Origin of Civilisation and primitive Condition of Man, ch. V, p. 212.

1.(231) [Trad. Legge, Bk II, I, III, 46 ; cf. Li ki, trad. Couvreur, t. I, p. 187].

1.(232) Chapter 37, I. 45. [Cf. Tcheou-li, trad. Biot, t. II, p. 393].

1.(233) [Trad. Legge, Bk II, I, I, 3 ; cf. Li ki, trad. Couvreur, t. I, p. 110].

1.(234) Sect. Ouen Sang.

1.(235) Sect. Tsa ki, II, 2.

1.(236) First year of the Ruler Yin.

1.(237) Trad. Legge, Bk XIX, I, 26 [Cf. Li ki, trad. Couvreur, t. II, p. 221].

1.(238) Sect. Iue ling, VI ; sect. Iue ling, II.

1.(239) [Cf. Tcheou-li, trad. Biot, t. I, p. 106]

1.(240) Sect. Sang ta ki, I.

1.(241) ap. Books of the Later Han Dynasty, ch. XVI, I. 7.

1.(242) Books of the Later Han Dynasty, ch. XVI, I. 1.

1. (243) Chapter IV, § 27. 


\section{The religious system of China}

vol. I

1.(244) The Social Life of the Chinese, ch. VII.

1.(245) Chapter 20, I. 46. [Cf. Tcheou-li, trad. Biot, t. I, p. 492].

1.(246) Chapter 6, I. 13. [Cf. Tcheou-li, trad. Biot, t. I, p. 125].

1.(247) [Trad. Legge, Bk II, II, III, 14 ; cf. Li ki, trad. Couvreur, t. I, p. 247].

1.(248) [Trad. Legge, Bk XVIII, I, II, 31 ; cf. Li ki, trad. Couvreur, t. II, p. 145].

1.(249) Chapter 6, I. 13. [Cf. Tcheou-li, trad. Biot, t. I, p. 125].

1.(250) See the Pen-ts'ao kang muh, ch. 8.

1.(251) Ch. 4, I. 15.

1.(252) Pao P'oh tszĕ, ch. 2, § 11.

1.(253) Pao P'oh tszĕ, ch. 1, § 3.

1.(254) Ming i pieh luh, ap. Pen-ts'ao kang muh, ch. 8.

1.(255) Ch. 33 , I. 18 seq.

1.(256) Ch. 27, I. 7 seq.

1.(257) [Trad. Legge, Bk XVIII, II, II, 12 ; cf. Li ki, trad. Couvreur, t. II, p. 184].

1.(258) Chapter 27, I. 9-13. [Cf. I li, trad. Couvreur, p. 448].

1.(259) Chapter 31, I. 14.

1.(260) Chapter 27, I. 14.

1.(261) Chapter 31, I. 14.

1.(262) Books of the Later Han Dynasty, ch. XVI, I. 1.

1.(263) Ch. 4, last §.

1.(264) Ch. 1.

1.(265) See Ku kin thu shu tsih ch'ing, sect. [], ch. 326.

1.(266) Ch. 52, I. 1, 18 and 23.

1.(267) Pliny, Naturalis Historiæ, lib. VII, cap. LV.

1.(268) Ch. 5, I. 2. [Cf. Mémoires historiques, trad. Chavannes, p. 4]

1.(269) Ch. 112, I, leaf 7.

1.(270) See the Cyclopædia Yuen kien lei han, ch. 48, and the Pei wen yun fu, ch 14, I 177.

1.(271) [Trad. Legge, Bk II, I, III, 40 ; cf. Li ki, trad. Couvreur, t. I, p. 185].

1.(272) [Trad. Legge, Bk XIX, II, 31 ; cf. Li ki, trad. Couvreur, t. II, p. 249].

1.(273) Khienlung edition of the Li ki, ch. XI, I. 47.

1.(274) Op. et loc. cit.

1.(275) Op. et cap. cit. I. 48.

1.(276) Op. et loc. cit.

1.(277) [Trad. Legge, Bk XIX, II, 32 ; cf. Li ki, trad. Couvreur, t. II, p. 249].

1.(278) [Trad. Legge, Bk XIX, II, 33 ; cf. Li ki, trad. Couvreur, t. II, p. 250].

1.(279) [Cf. Meng tzeu, trad. Couvreur, p. 393].

1.(280) [Trad. Legge, Bk II, I, III, 4 ; cf. Li ki, trad. Couvreur, t. I, p. 165]. 


\title{
The religious system of China
}

\author{
vol. I
}

1.(281) Nan hwa chen king, ch. 8, § 3 .

1.(282) Chapter 28, I. 54.

1.(283) Chapter 30, I. 41.

1.(284) [Trad. Legge, Bk II, I, III, 40 ; cf. Li ki, trad. Couvreur, t. I, p. 185].

1.(285) [Trad. Legge, Bk XIX, II, 40 ; cf. Li ki, trad. Couvreur, t. II, p. 255].

1.(286) [Trad. Legge, Bk II, II, II, 16 ; cf. Li ki, trad. Couvreur, t. I, p. 227].

1.(287) [Cf. Louen yu, trad. Couvreur].

1.(288) [Trad. Legge, Bk II, I, III, 4 ; cf. Li ki, trad. Couvreur, t. I, p. 165].

1.(289) Ch. 50, I. 2 seq.

1.(290) Pen-ts'ao shih i, mentioned on page 201.

1.(291) Pen ts'ao kang muh, ch. 35, II.

1.(292) Ch. 14.

1.(293) Ch. 35, I.

1.(294) Ku kin thu shu tsih ch'ing, sect. [], ch. 240.

1.(295) Pliny, Naturalis Historiæ, lib. XVI.

1.(296) Ku kin thu shu tsih ch'ing, sect. [], ch. 202.

1.(297) Pao P'oh tszĕ, ch. I, § 3.

1.(298) The same work, ch. 2, § 11.

1.(299) See the Koh chi king yuen, ch. 64.

1.(300) Koh chi king yuen, ch. 64.

1. (301) Koh chi king yuen, ch. 64.

1.(302) Ku kin thu shu tsih ch'ing, sect. [], ch. 202.

1. $(\underline{303})$ Yuen kien lei han, ch. 412.

1.(304) The same work, ch. 413.

1.(305) Ch. 2, § 11.

1.(306) Koh chi king yuen, ch. 64 ; and Yuen kien lei han, ch. 412.

1.(307) Koh chi king yuen, ch. 64.

1.(308) Chapt. V.

1.(309) Chapt. 34.

1.(310) Syllabic Dictionary of the Chinese Language.

1.(311) Journal of the North China Branch of the Royal Asiatic Society, Vol. 15, p. 28.

1.(312) Pen ts'ao kang muh, ch. 35, I.

1.(313) The Khanghi Dictionary.

1.(314) [Trad. Legge, Bk II, II, III, 16 ; cf. Li ki, trad. Couvreur, t. I, p. 250].

1.(1ㅗ) [Trad. Legge, Bk II, I, III, 10 ; cf. Li ki, trad. Couvreur, t. I, p. 172].

1.(316) Khung-tszĕ kia yū, probably written in the third century.

1.(317) Ch. $1, \S[]$. This episode is also partly recorded in the Li ki : see the quotation on page 292. 


\section{The religious system of China}

vol. I

1.(318) Domestic Discourses, ch. 9.

1.(319) [Trad. Legge, Bk II, I, III, 31 ; cf. Li ki, trad. Couvreur, t. I, p. 180].

1.(르) [Trad. Legge, Bk V, II, 14 ; cf. Li ki, trad. Couvreur, t. I, p. 449].

1.(321) See the Ku kin thu shu tsih ch'ing, sect. [], ch. 252.

1.(322) Nan hwa chen king, ch. 10, § 32.

1.(련 $)$ Books of the Later Han Dynasty, ch. 94, I. 15.

1.(324) Chapt. III, § 12.

1.(325) See the Kia li.

1.(326) Chapter 12, I. 39. [Cf. Tcheou-li, trad. Biot, t. I, p. 282].

1.(327) Chapt. 16, leaf 2.

1. (328) Ku kin thu shu tsih ch'ing, sect. [], ch. 56.

1.(329) Chapt. 27, I. 2 seq. [Cf. Mémoires historiques, trad. Chavannes, p. 342]

1.(330) $25^{\text {th }}$ year of the Ruler Ch'ao. [Cf. Tso tchouan, trad. Couvreur, [III], p. 398, § 8]

1.(331) Sect. 20.

1.(332) Ku kin thu shu tsih ch'ing, sect. [], ch. 56.

1. (333) Chapt. 52, I. 1.

1.(334) Chapt. 34.

1.(335) Chapt. 77, leaf 22.

1.(336) Chapt. 37.

1.(337) Pen-ts'ao kang muh, chapt. 37.

1. $(\underline{338})$ Chapt. 26, leaf 36-38.

1.(339) Chapt. 31, leaf 15 and 16.

1.(340) Chapt. 26, I. 38 sqq.

1.(341) Leaf 40.

1.

1. $(\underline{343})$ Leaf 44.

1.(344) Sect. Tsa ki, II, 1.

1.(345) [Trad. Legge, Bk XIX, II, 10 ; cf. Li ki, trad. Couvreur, t. II, p. 232].

1.(346) Chapt. 26, leaf 45-49.

1.(낙) Chapt. 27, I. 8.

1.(348) Chapt. 27, I. 14-19.

1.(349) Chapt. 31, I. 17.

1.(350) Chapt. 27, I. 21.

1.(351) Chapt. 31, I. 17.

1.(352) Chapt. 27, I. 26-29.

1. (ㅎ5ㄱ) Sect. Sang ta ki, II.

1.(354) Chapt. 27, I. 37-39. 


\section{The religious system of China}

vol. I

1.(ㅎ5다 $)$ Sect. Sang ta ki, II.

1.(356) Chapt. 27, I. 39-47.

1.(357) Chapt. 28, I. 1 and 2.

1. $(\underline{358})$ Sect. Sang ta ki, II.

1.(359) Chapt. 28, I. 12-14.

1.(360) Chapt. 31, I. 23.

1.(361) Chapt. 28, I. 14-16.

1.(362) Chapt. 9, § [].

1. (363) Chapt. 52, I. 1.

1.(364) Chapt. 52, I. 18.

1.(하) Chapt. 52, I. 2.

1.(366) Ninth year of the Ruler Wen.

1.(367) Trad. Legge, Bk XVIII, I, II, 32 [Cf. Li ki, trad. Couvreur, t. II, p. 147].

1.(368) Chapt. 31, I. 23 seq.

1.(369) Trad. Legge, Bk XIX, II, 34 [Cf. Li ki, trad. Couvreur, t. II, p. 250].

1. (370) Chapt. 52, I. 2.

1.(371) Chapt. 21, I. 44. [Cf. Tcheou-li, trad. Biot, t. II, p. 21].

1.(372) Chapt. 59, I. 39.

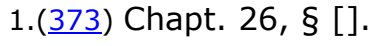

1.(374) Chapt. 37.

1.(375) Chapt. 25, § [].

1.(376) See Chapt. 2, I. 30.

1.(377) Chapt. 66, I. 5.

1.(378) Trad. Legge, Bk V, I, 1 [Cf. Li ki, trad. Couvreur, t. I, p. 411].

1.(379) Chapt. 16, I. 1 sqq.

1.(380) Ch. 47, I. 6. The solemnity in described in detail in ch. 21 of the Ta Ts'ing thung li.

1.(381) Chapt. 45, leaf 2. This episode is related also in the Books of the Southern Ts'i Dynasty, ch. 26, leaf 1.

1.(382) The Chinese Recorder and Missionary Journal, XIX, p. 456.

1.(383) Spencer, Principles of Sociology, § 84.

1.(384) Sect. Li iun, I.

1.(요) Trad. Legge, Bk II, I, III, 32 [Cf. Li ki, trad. Couvreur, t. I, p. 181].

1.(386) Chapt. 26, I. 13.

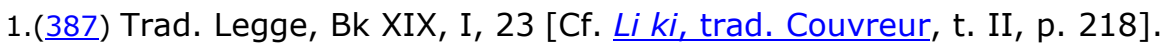

1.(388) Trad. Legge, Bk II, II, I, 24 [Cf. Li ki, trad. Couvreur, t. I, p. 200].

1.(389) Chapt. IV, § [].

1.(이) Sect. T'an koung, II, 2. 


\section{The religious system of China}

vol. I

1.(391) Chapt. 26, I. 14.

1.(392) Chapt. 31, I. 9.

Part I $: \underline{I}-\underline{I I}-\underline{I I I}-\underline{\text { IV }}-\underline{\mathrm{V}}-\underline{\mathrm{VI}}-\underline{\mathrm{VII}}-\underline{\mathrm{VIII}}-\underline{\mathrm{IX}}$

Part II $: \underline{I}-\underline{\text { II }}-\underline{\text { III }}-\underline{\text { IV }}-\underline{\mathrm{V}}-\underline{\mathrm{VI}}-\underline{\mathrm{VII}}$

Notes

@ 